JORGE RODOLFO ESCALANTE ZEGARRA

\title{
AVALIAÇÃO DE MISTURAS PRODUZIDAS COM LIGANTES ASFÁLTICOS PERUANOS CONVENCIONAL PEN 60/70 E MODIFICADOS POR POLÍMERO SBS TIPO I 60/60 E PG 76 -22
}

Dissertação apresentada à Escola de Engenharia de São Carlos, da Universidade de São Paulo, como parte dos requisitos para a obtenção do Título de Mestre em Engenharia Civil: Infra-Estrutura de Transportes.

Orientador: Prof. Dr. José Leomar Fernandes Júnior

São Carlos 

Dedico este trabalho aos meus pais, Rafael e Luz Marina, a meus irmãos Thany e Jafett, a meus sobrinhos Rafael e Marcela e à Carmen por todo apoio, incentivo, amor e carinho. 



\section{AGRADECIMENTOS}

A Deus e a minha família que sempre me apoiaram e incentivaram. Em especial a minha mãe, Luz Marina que mesmo com saudades me encorajou em todos os momentos desta etapa da minha vida.

Ao meu pai Rafael, pelo exemplo constante de trabalho, honestidade, esforço e força de vontade. Muito do que eu sou me espelhei em você.

Ao Professor Dr. José Leomar Fernandes Júnior pelo apoio, estimulo e atenção durante o direcionamento e orientação deste trabalho.

Ao Professor Dr. Glauco Túlio Pessa Fabri pelas sugestões, incentivo e apoio durante o período de desenvolvimento deste trabalho.

Aos professores do Departamento de Engenharia de Transportes da EESC-USP, em especial ao Professor Dr. Alexandre B. Parreira e ao Professor Dr. Glauco T. P. Fabbri, pelas sugestões para a culminação deste trabalho.

Aos Professores Dr. Alexandre B. Parreira e a Professora Dra. Suelly H. A. Barroso pela contribuição na banca de mestrado.

Ao Conselho Nacional de Densenvolvimento Científico e Tecnológico - CNPq pela bolsa de estudo concedida.

Ao Rômulo Constantino pela sua amizade que não tem preço e por seu suporte técnico de todas as horas de trabalho.

À Betunelkoch Asfaltos, a toda a equipe técnica, aos MSc. Rômulo e Leandro e aos técnicos Adalberto, Saulo, Tiago e Paulo pelo apoio no desenvolvimento desta pesquisa e pela oportunidade de convívio e aprendizado nesse Laboratório durante todo o período. 
Aos meus amigos Jesner Sereni Ildefonso, Marcos Bottene Cunha, Alex Arancibia Suarez e Diogo Tocacelli Colella pela amizade incondicional, convívio e colaboração direta neste trabalho.

Aos meus amigos Bruno, Mateus, André, Luiz, Gustavo, Ivan, Fabio, Adalberto, Frede, Mateus D, Daniel, Michael, Leandro, Celso, Weslley, Francis, Luis, Paulo, Vivian, Ana, Adriana, Cira, Cida, Andréa, Vanessa, Márcia, Camila, César, Waldo, Elmer, Julio, Edwin, Soledad, Shermila, Tany e a todos os colegas do Departamento de Transportes pelo convívio e amizade.

Aos funcionários do departamento de Transportes Heloisa, Elisabeth, Carlos, Magaly, Alexandre, Vicente, Paulinho e Suely.

Aos técnicos do Laboratório de Estradas da EESC-USP, Gigante e Paulo que deram sua contribuição na realização deste trabalho; e em especial ao João pela amizade e apoio nos ensaios de laboratório.

À Tecnologia de Materiales (TDM), pelo fornecimento e envio do ligante asfáltico do Peru utilizado na pesquisa.

Ao CENPES/PETROBRAS, à DSc. Leni Leite, Adriana Tinoco e Luis Nascimento pelo apoio nos ensaios de DSR e BBR após RTFOT e PAV.

À pedreira Bandeirantes, pelo fornecimento dos agregados para a pesquisa. 


\section{RESUMO}

ZEGARRA, J. R. E. (2007). Avaliação de misturas produzidas com ligantes asfálticos peruanos convencional PEN 60/70 e modificados por polímero SBS Tipo I 60/60 e PG 76 -22. Dissertação (Mestrado) - Escola de Engenharia de São Carlos, Universidade de São Paulo, São Carlos, 2007.

Os objetivos deste trabalho são avaliar o comportamento de asfaltos peruanos convencional CAP PEN 60/70 e modificados por polímero SBS Tipo I 60/60 e PG 76 -22, em misturas asfálticas densas, sem e com envelhecimento em curto prazo, e estabelecer a distribuição do Grau de Desempenho (PG) de ligantes asfálticos com base nas condições climáticas de cada região do Peru. Para a classificação por desempenho os ligantes asfálticos procedentes de Peru foram submetidos aos ensaios convencionais e da especificação Superpave: penetração, ponto de amolecimento, viscosidade Brookfield, ponto de fulgor, retorno elástico, estabilidade a estocagem, envelhecimento em curto prazo (RTFOT), envelhecimento em longo prazo (PAV), cisalhamento dinâmico (DSR) e rigidez à fluência na flexão (BBR). Para a avaliação das propriedades mecânicas, sem envelhecimento e com envelhecimento em curto prazo, foram moldados um total de 196 corpos de prova, submetidos aos ensaios Marshall, resistência à tração, resistência à tração após umidade induzida, módulo de resiliência, fluência por compressão uniaxial estática, fluência por compressão uniaxial dinâmica e vida de fadiga. Os resultados dos ensaios mostram que o proceso de modificação dos asfaltos por polímero melhora as caracteristicas reológicas do ligante, apresentando menor índice de susceptibilidade térmica e maior resistência ao envelhecimento e melhorando o comportamento das misturas asfálticas em todos os ensaios mecânicos. Esses resultados foram confirmados pela análise estrutural com o programa computacional Elsym5, nas duas condições de envelhecimento estudadas.

Palavras Chave: Misturas asfálticas, asfaltos peruanos, asfaltos modificados, polímero SBS. 


\section{ABSTRACT}

ZEGARRA, J. R. E. (2007). Evaluation of asphalt mixtures produced with conventional peruvian asphalt binder PEN 60/70 and SBS polymer-modified Type I 60/60 and PG $76-22$. M.Sc. Thesis - Engineering School of Sao Carlos, University of Sao Paulo, Sao Carlos, 2007.

The main goal of this work is the evaluation of the behavior of conventional peruvian asphalt binder AC PEN 60/70 and SBS polymer-modified asphalts I 60/60 and PG 76-22, when used in hot-mix asphalt (HMA), under both conditions with and without short-term aging. It aims also to establish the asphalt binder performance grade (PG), which is based on the weather conditions, for different Peruvian regions. The Peruvian asphalt binders were submitted to conventional and Superpave laboratory tests: penetration, softening point, Brookfield viscosity, flash point, elastic recovery, storage stability, rolling thin film oven test (RTFOT), pressure aging vessel (PAV), dynamic shear rheometer (DSR) and bending beam rheometer (BBR). For the evaluation of mechanical properties 196 specimen were sumitted to Marshall, indirect tensile strength under static loading, indirect tensile strength under static loading after induced moisture, resilient modulus under dynamic diametric compression, static and dynamic creep and fatigue tests. The result show that polymer-modified asphalt binder improve rheological characteristic, in terms of thermal susceptibility and resistance to aging, and also improve the asphalt mixtures behavior, which was verified in all of the mechanical tests and after the structural analysis performed with the Elsym5 program, for all of the shortterm aging conditions studied in this work.

Keywords: Asphalt mixtures, Peruvian asphalt, modified asphalt, SBS polymer. 


\section{RESUMEN}

ZEGARRA, J. R. E. (2007). Evaluación de mezclas asfálticas producidas con ligantes asfálticos peruanos convencional PEN 60/70 y modificados por polímero SBS Tipo I 60/60 y PG 76 -22. Disertación (Maestria) - Escuela de Ingeniería de São Carlos, Universidad de São Paulo, São Carlos, 2007.

Los objetivos de este trabajo son evaluar el comportamiento de asfaltos peruanos convencional CAP PEN 60/70 y modificados por polímero SBS Tipo I 60/60 y PG 76 -22, en mezclas asfálticas densas, sin y con envejecimiento a corto plazo, y establecer la distribución del Grado de Desempeño (PG) de ligantes asfálticos con base en las condiciones climáticas de cada región de Perú. Para la clasificación por desempeño los ligantes asfálticos procedentes de Perú fueron sometidos a los ensayos convencionales y de las especificaciones Superpave: penetración, punto de ablandamiento, viscosidad Brookfield, punto de inflamación, retorno elástico, estabilidad para almacenaje, envejecimiento a corto plazo (RTFOT), envejecimiento a largo plazo (PAV), corte dinámico (DSR) y rigidez a fluencia en flexión (BBR). Para la evaluación de las propiedades mecánicas, sin envejecimiento y con envejecimiento en corto plazo, fueron moldados un total de 196 cuerpos de prueba, sometidos a los ensayos Marshall, resistencia a tracción, resistencia a tracción retenida al daño inducido por la humedad, módulo de resiliencia, fluencia por compresión uniaxial estática, fluencia por compresión uniaxial dinámica y vida a fatiga. Los resultados de los ensayos muestran que el proceso de modificación de los asfaltos por polímero mejora las características reológicas del ligante, presentando menor índice de susceptibilidad térmica y mayor resistencia al envejecimiento y mejorando el comportamiento de las mezclas asfálticas en todos los ensayos mecánicos. Esos resultados fueron confirmados por el análisis estructural con el programa computacional Elsym5, en las dos condiciones de envejecimiento estudiadas.

Palabras Clave: Mezclas asfálticas, asfaltos peruanos, asfaltos modificados, polímero SBS. 


\section{Lista de Figuras}

Figura 1.1 - Mapa de localização de Refinarias de petróleo do Peru.

Figura 2.1 - Exemplo de granulometria Superpave para um Diâmetro Máximo Nominal de 12.5 mm.

Figura 2.2 - Influência da composição química do CAP na compatibilidade de asfaltos modificados por SBS.

Figura 2.3 - Alteração do ponto de amolecimento do asfalto modificado com o teor de polímero. ..... 29

Figura 2.4 - Observação de estruturas de asfalto modificado com diferentes teores de SBS no microscópio de reflexão de fluorescência.

Figura 2.5 - Alternativas para produção de asfalto modificado por polímero.

Figura 2.6 - Diagrama de produção de asfaltos modificados com elastômeros termoplásticos estirênicos.

Figura 2.7 - Tipos de curvas granulométricas para misturas asfálticas.

Figura 2.8 - Exemplo de granulometria Superpave.

Figura 2.9 - Compactador Giratório Superpave

Figura 2.10 - Deformação permanente nas trilhas de roda

Figura 2.11 - Trincas por fadiga 58

Figura 2.12 - Trincas por baixa temperatura 61

Figura 3.1 - Mapa da distribuição do PG do ligante asfáltico, sem considerar condições de tráfego. .. 74

Figura 4.1 - Pedreira Bandeirantes - coleta de agregados. .78

Figura 4.2 - Determinação da densidade do agregado graúdo 80

Figura 4.3 - Determinação da densidade do agregado miúdo.

Figura 4.4 - Máquina de abrasão "Los Angeles".

Figura 4.5 - Análise Granulométrica dos agregados utilizado na pesquisa. 86

Figura 4.6 - Granulometria de agregados peruanos utilizado na pesquisa. 86

Figura 4.7 - Ligantes Asfálticos Peruanos utilizados na pesquisa. 
Figura 4.8 - Produção de asfalto modificado por polímero SBS PG 76 -22. .89

Figura 4.9 - Ensaio de Penetração. 91

Figura 4.10 - Ensaio de Ponto de Amolecimento..................................................................................

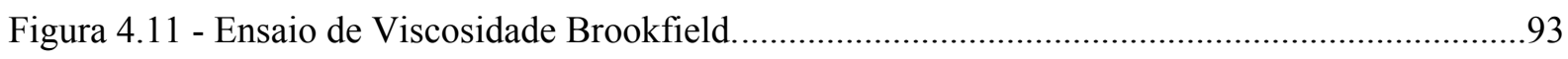

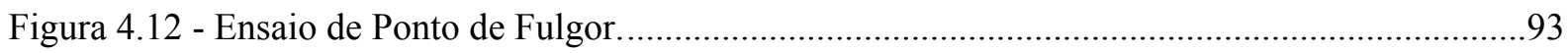

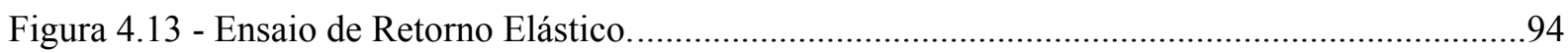

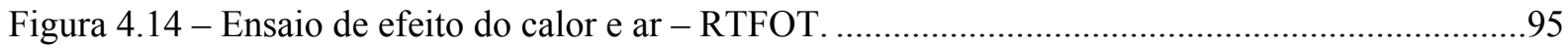

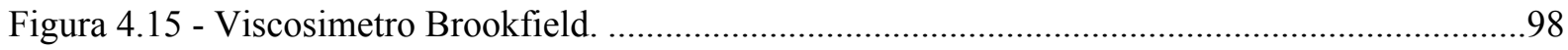

Figura 4.16 - Reômetro de Cisalhamento Dinâmico................................................................................99

Figura 4.17 - Cálculo do módulo complexo G* e do ângulo de fase $\delta$ medidos no DSR......................99

Figura 4.18 - Ensaio de módulo complexo de cisalhamento - DSR ....................................................100

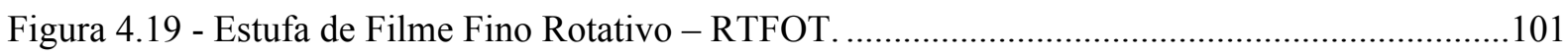

Figura 4.20 - Vaso de Envelhecimento Sob Pressão - PAV .................................................................102

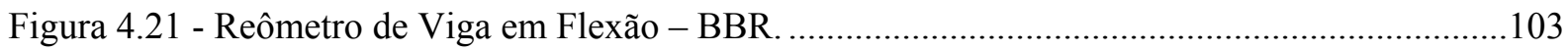

Figura 4.22 - Distribuição granulométrica da Mistura..........................................................................106

Figura 4.23 - Seleção e preparação dos agregados minerais................................................................108

Figura 4.24 - Dosagem controlada de agregados para cada corpo de prova ......................................110

Figura 4.25 - Temperaturas de usinagem e compactação do CAP PEN 60/70.....................................112

Figura 4.26 - Temperaturas de usinagem e compactação do AMP Tipo I 60/60.................................113

Figura 4.27 - Temperaturas de Usinagem e compactação do AMP PG 76 -22...................................113

Figura 4.28 - Ensaio de Densidade Máxima Teórica (Método Rice)...................................................119

Figura 4.29 - Ensaio de Estabilidade e fluência Marshall.....................................................................123

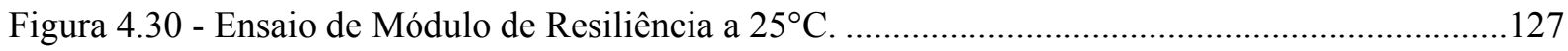

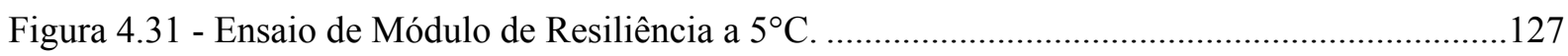

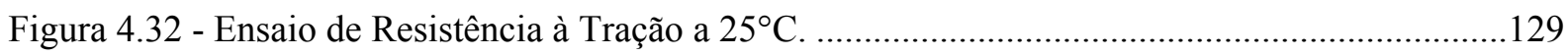

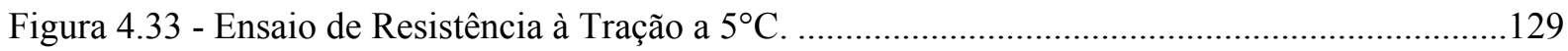

Figura 4.34 - Ensaio de Resistência à Tração retida por umidade induzida..........................................131

Figura 4.35 - Ensaio de Fluência por Compressão Uniaxial Estática (creep estático)..........................135 
Figura 4.36 - Ensaio de Fluência por Compressão Uniaxial Dinâmica (creep dinâmico). 138

Figura 4.37 - Ensaio de Fadiga por compressão diametral.

Figura 5.1 - Enquadramento da curva granulométrica da mistura asfáltica escolhida na especificação Superpave e na faixa $\mathrm{C}$ do DNER. 145

Figura 5.2 - Variação da Penetração em ligante sem envelhecimento e após RTFOT.

Figura 5.3 - Variação do Ponto de Amolecimento em ligante sem envelhecimento e após RTFOT. . 148

Figura 5.4 - Variação do IST em ligante sem envelhecimento e após RTFOT. 149

Figura 5.5 - Viscosidade sem envelhecimento dos ligantes asfálticos utilizados na pesquisa. 150

Figura 5.6 - Viscosidade após RTFOT dos ligantes asfálticos utilizados na pesquisa. 151

Figura 5.7 - Variação da viscosidade em ligante sem envelhecimento e após RTFOT. 151

Figura 5.8 - Variação do retorno elástico em ligante sem envelhecimento e após RTFOT. 152

Figura 5.9 - Classificação Superpave dos ligantes asfálticos utilizados na pesquisa. 154

Figura 5.10 - Teor de projeto sem envelhecimento - CAP PEN 60/70. 155

Figura 5.11 - Teor de projeto sem envelhecimento - AMP Tipo I 60/60. 155

Figura 5.12 - Teor de projeto sem envelhecimento - AMP PG 76 -22 ........................................... 156

Figura 5.13 - Teor de projeto com envelhecimento em curto prazo - CAP PEN 60/70 ...................... 156

Figura 5.14 - Teor de projeto com envelhecimento em curto prazo - AMP Tipo I 60/60................... 157

Figura 5.15 - Teor de projeto com envelhecimento em curto prazo - AMP PG 76 -22..................... 157

Figura 5.16 - Valores médios da densidade aparente das três misturas. 160

Figura 5.17 - Valores médios da densidade máxima teórica das três misturas. 160

Figura 5.18 - Variação do volume de vazios em função do teor de ligante. 161

Figura 5.19 - Variação do VAM em função do teor de ligante. 161

Figura 5.20 - Valores médios da RBV em função do teor de ligante. 162

Figura 5.21 - Valores médios das estabilidades Marshall em função do teor de ligante. 162

Figura 5.22 - Valores médios das fluências Marshall das três misturas. 163

Figura 5.23 - Valores médios da capacidade de suporte Marshall das três misturas. 163

Figura 5.24 - Variação da densidade aparente em função do teor de ligante. 165

Figura 5.25 - Variação da $\mathrm{Gmm}$ em função do teor de ligante. 166 
Figura 5.26 - Variação do volume de vazios em função do teor de ligante. 166

Figura 5.27 - Variação do VAM em função do teor de ligante 167

Figura 5.28 - Variação da RBV em função do teor de ligante. 167

Figura 5.29 - Variação da estabilidade Marshall em função do teor de ligante. 168

Figura 5.30 - Variação da fluência Marshall em função do teor de ligante 168

Figura 5.31 - Variação da CSM em função do teor de ligante 169

Figura 5.32 - Variação do $\mathrm{MR}$ a $25^{\circ} \mathrm{C}$ em função da condição de envelhecimento. 172

Figura 5.33 - Variação do $\mathrm{MR}$ a $5^{\circ} \mathrm{C}$ em função da condição de envelhecimento. 173

Figura 5.34 - Variação do MR das misturas em função da temperatura e condição de envelhecimento em curto prazo. 173

Figura 5.35 - Variação da RT a $25^{\circ} \mathrm{C}$ em função da condição de envelhecimento. 175

Figura 5.36 - Variação da RT a $5^{\circ} \mathrm{C}$ em função da condição de envelhecimento. 176

Figura 5.37 - Variação da RT em função da temperatura de ensaio e condição de envelhecimento. ..176 Figura 5.38 - Variação da relação $\mathrm{MR} / \mathrm{RT}$ a $25^{\circ} \mathrm{C}$ em função da condição de envelhecimento. 179

Figura 5.39 - Variação da relação MR/RT a $5^{\circ} \mathrm{C}$ em função da condição de envelhecimento. 179

Figura 5.40 - Variação da relação MR/RT em função da temperatura de ensaio e condição de envelhecimento. 180

Figura 5.41 - Variação da RTR em função da condição de envelhecimento. 181

Figura 5.42 - Variação da RMR em função da condição de envelhecimento. 183

Figura 5.43 - Variação das deformações em amostras sem envelhecimento. 186

Figura 5.44 - Variação das deformações em amostras com 2 horas de envelhecimento. 186

Figura 5.45 - Variação das deformações em amostras com 4 horas de envelhecimento. 187

Figura 5.46 - Variação da recuperação elástica em função da condição de envelhecimento. .187

Figura 5.47 - Variação do módulo de fluência a 3600 segundos em função da condição de envelhecimento. 189

Figura 5.48 - Variação do módulo de fluência a 4500 segundos em função da condição de envelhecimento.

Figura 5.49 - Variação da inclinação em função da condição de envelhecimento. 
Figura 5.50 - Variação da deformação em função da condição de envelhecimento. 192

Figura 5.51 - Variação da inclinação da curva de fluência em função da condição de envelhecimento.

Figura 5.52 - Variação do módulo de fluência em função da condição de envelhecimento.

Figura 5.53 - Curvas de Fadiga em função da diferença de tensões para CAP PEN 60/70. 195

Figura 5.54 - Curvas de Fadiga em função da deformação resiliente para CAP PEN 60/70. 196

Figura 5.55 - Curvas de Fadiga em função da diferença de tensões para AMP Tipo I 60/60. 198

Figura 5.56 - Curvas de Fadiga em função da deformação resiliente para AMP Tipo I 60/60. 199

Figura 5.57 - Curvas de Fadiga em função da diferença de tensões para AMP PG 76 -22.................. 201

Figura 5.58 - Curvas de Fadiga em função da deformação resiliente para AMP PG 76 -22............... 202

Figura 5.59 - Curvas de Fadiga sem envelhecimento em função da diferença de tensões. 204

Figura 5.60 - Curvas de Fadiga com 2 h de envelhecimento em função da diferença de tensões. 204

Figura 5.61 - Curvas de Fadiga com 4 h de envelhecimento em função da diferença de tensões. 205

Figura 5.62 - Curvas de Fadiga sem envelhecimento em função da deformação resiliente. 205

Figura 5.63 - Curvas de Fadiga com 2 h de envelhecimento em função da deformação resiliente..... 206

Figura 5.64 - Curvas de Fadiga com 4 h de envelhecimento em função da deformação resiliente..... 206

Figura 5.65 - Perfil utilizado, características e localização do ponto de tensões e deformações mais críticas

Figura 5.66 - Vida de Fadiga das misturas asfálticas estudadas para uma estrutura com capa de $10 \mathrm{~cm}$ de espessura, para cada condição de envelhecimento. 209

Figura 5.67- Vida de Fadiga das misturas asfálticas estudadas para uma estrutura com capa de 7,5 cm de espessura, para cada condição de envelhecimento 


\section{Lista de Tabelas}

Tabela 2.1 - Especificação granulométrica para material de enchimento ou filer. .11

Tabela 2.2 - Pontos de Controle conforme o Diâmetro Máximo Nominal. 13

Tabela 2.3 - Zona de restrição de acordo com o diâmetro máximo nominal. .14

Tabela 2.4 - Especificação SUPERPAVE: requisitos das propriedades de consenso. .15

Tabela 2.5 - Aparelhos de ensaio do método Superpave. .40

Tabela 2.6 - Ensaio Marshall - Valores limites para misturas convencionais. .48

Tabela 2.7 - Ensaio Marshall - Valores limites para misturas modificadas por polímero. .48

Tabela 2.8 - Recomendações SUPERPAVE para Vazios no Agregado Mineral. .51

Tabela 2.9 - Recomendações SUPERPAVE para Vazios Preenchidos com Asfalto. .52

Tabela 2.10 - Recomendações Superpave para a porcentagem da Densidade Máxima Medida. .53

Tabela 2.11 - Fatores que interferem no desempenho de misturas asfálticas quanto à deformação permanente. .56

Tabela 2.12 - Fatores que afetam a rigidez na vida de fadiga das misturas asfálticas .60

Tabela 3.1 - Intervalos para o PG. .65

Tabela 3.2 - Novos ajustes para a seleção de ligantes asfálticos por nível de tráfego e velocidade. .....71

Tabela 3.3 - Cálculo do PG do ligante asfáltico produzido. .75

Tabela 4.1 - Características dos agregados peruanos (pedreira "La Gloria”). .87

Tabela 4.2 - Características dos agregados brasileiros (pedreira "Bandeirantes"). .88

Tabela 4.3 - Resultados de caracterização dos asfaltos PEN 50/70, asfalto modificado por polímero AMP Tipo I 60/60 e asfalto modificado por polímero AMP PG 76 -22 .96

Tabela 4.4 - Resultados de caracterização pelo método Superpave dos asfaltos PEN 60/70, AMP SBS Tipo I 60/60 e AMP SBS PG $76-22$.

Tabela 4.5 - Temperaturas para usinagem e compactação das misturas asfálticas. 113

Tabela 4.6 - Quantidade de corpos de prova utilizados por ensaio. 122 
Tabela 4.7 - Exemplos de tempos de carregamento e repouso, tensão de carregamento e temperatura de ensaio segundo vários autores.

Tabela 5.1 - Resultados do ensaio de densidade máxima teórica da mistura. 158

Tabela 5.2 - Resultados volumétricos e de estabilidade e fluência Marshall - CAP PEN 60/70 sem envelhecimento.

Tabela 5.3 - Resultados volumétricos e de estabilidade e fluência Marshall - AMP Tipo I 60/60 sem envelhecimento.

Tabela 5.4 - Resultados volumétricos e de estabilidade e fluência Marshall - AMP PG 76 -22 sem envelhecimento,

Tabela 5.5 - Resultados volumétricos e de estabilidade e fluência Marshall - CAP PEN 60/70 com envelhecimento.

Tabela 5.6 - Resultados volumétricos e de estabilidade e fluência Marshall - AMP Tipo I 60/60 com envelhecimento.

Tabela 5.7 - Resultados volumétricos e de estabilidade e fluência Marshall - AMP PG 76 -22 com envelhecimento. 165

Tabela 5.8 - Resultados do ensaio de módulo de resiliência das misturas com CAP PEN 60/70_...... 170

Tabela 5.9 - Resultados do ensaio de módulo de resiliência das misturas com AMP Tipo I 60/60 ... 171

Tabela 5.10 - Resultados do ensaio de módulo de resiliência das misturas com AMP PG 76 -22. 171

Tabela 5.11 - Resultados do ensaio de resistência à tração das misturas com CAP PEN 60/70. 174

Tabela 5.12 - Resultados do ensaio de resistência à tração das misturas com AMP Tipo I 60/60 ...... 174

Tabela 5.13 - Resultados do ensaio de resistência à tração das misturas com AMP PG 76 -22......... 174

Tabela 5.14 - Resultados da relação MR/RT das misturas com CAP PEN 60/70.............................. 177

Tabela 5.15 - Resultados da relação MR/RT das misturas com AMP Tipo I 60/60 .......................... 177

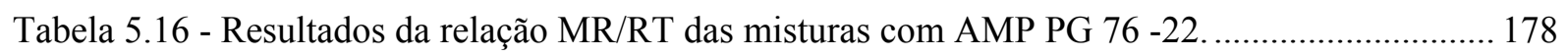

Tabela 5.17 - Resultados da RTR das misturas com CAP PEN 60/70 …............................................... 180

Tabela 5.18 - Resultados da RTR das misturas com AMP Tipo I 60/60 ....................................... 180

Tabela 5.19 - Resultados da RTR das misturas com AMP PG 76 -22 ........................................... 181

Tabela 5.20 - Resultados da MRR das misturas com CAP PEN 60/70 ............................................. 182 
Tabela 5.21 - Resultados da MRR das misturas com AMP Tipo I 60/60.

Tabela 5.22 - Resultados da MRR das misturas com AMP PG 76 -22.

Tabela 5.23 - Resultados do ensaio de fluência por compressão uniaxial estática das misturas com

CAP PEN 60/70.

Tabela 5.24 - Resultados do ensaio de fluência por compressão uniaxial estática das misturas com

AMP Tipo I 60/60.

Tabela 5.25 - Resultados do ensaio de fluência por compressão uniaxial estática das misturas com

AMP PG $76-22$.

Tabela 5.26 - Critério para controle da deformação através de valores obtidos no ensaio de fluência.

Tabela 5.27 - Critério do módulo de fluência para 1 hora de carregamento.

Tabela 5.28 - Resultados do ensaio de fluência por compressão uniaxial dinâmica das misturas com

CAP PEN 60/70.

Tabela 5.29 - Resultados do ensaio de fluência por compressão uniaxial dinâmica das misturas com

AMP Tipo I 60/60

Tabela 5.30 - Resultados do ensaio de fluência por compressão uniaxial dinâmica das misturas com AMP PG $76-22$.

Tabela 5.31 - Vida de Fadiga das misturas com CAP PEN 60/70 sem envelhecimento.

Tabela 5.32 - Vida de Fadiga das misturas com CAP PEN 60/70 com 2 h de envelhecimento. 194

Tabela 5.33 - Vida de Fadiga das misturas com CAP PEN 60/70 com 4 h de envelhecimento. 195

Tabela 5.34 - Vida de Fadiga das misturas com AMP Tipo I 60/60 sem envelhecimento.

Tabela 5.35 - Vida de Fadiga das misturas com AMP Tipo I 60/60 com 2 h de envelhecimento.

Tabela 5.36 - Vida de Fadiga das misturas com AMP Tipo I 60/60 com 4 h de envelhecimento.

Tabela 5.37 - Vida de Fadiga das misturas com AMP PG 76 -22 sem envelhecimento. .200

Tabela 5.38 - Vida de Fadiga das misturas com AMP PG 76 -22 com 2 h de envelhecimento. .200

Tabela 5.39 - Vida de Fadiga das misturas com AMP PG 76 -22 com 4 h de envelhecimento. .201

Tabela 5.40 - Parâmetros dos modelos de vida de Fadiga das misturas asfálticas sem envelhecimento 
Tabela 5.41 - Parâmetros dos modelos de vida de Fadiga das misturas asfálticas com 2 h de envelhecimento

Tabela 5.42 - Parâmetros dos modelos de vida de Fadiga das misturas asfálticas com 4 h de envelhecimento

Tabela 5.43 - Vida de fadiga das misturas asfálticas para uma estrutura com capa de $10 \mathrm{~cm}$ de espessura, em cada condição de envelhecimento. 208

Tabela 5.44 - Vida de fadiga das misturas asfálticas par uma estrutura com capa de 7,5 cm de espessura, em cada condição de envelhecimento. 


\section{Lista de Abreviaturas e Siglas}

AASHO: $\quad$ American Association of State Highway Officials

AASTHO: $\quad$ American Association of State Highway and Transportation Officials

ABCR: $\quad$ Associação Brasileira de Concessionárias Rodoviárias

ABNT: $\quad$ Associação Brasileira de Normas Técnicas

AMP: $\quad$ Asfalto Modificado por Polímero

ASTM: $\quad$ American Society for Testing and Materials

BBR: $\quad$ Bending Beam Rheometer

CA: $\quad$ Comissão de Asfalto

CAP: $\quad$ Cimento Asfáltico de Petróleo

CBUQ: $\quad$ Concreto Betuminoso Usinado a Quente

CMHB: $\quad$ Coarse Matrix High Binder

CNP: $\quad$ Conselho Nacional do Petróleo

cP: $\quad$ centi Poise

CP: $\quad$ Corpo de prova

CSM: $\quad$ Capacidade de Suporte Marshall

d: $\quad$ Densidade aparente do corpo de prova

D: $\quad$ Diâmetro do corpo de prova

DMN: Diâmetro Máximo Nominal

DNC: Departamento Nacional de Combustíveis

DNER: Departamento Nacional de Estradas de Rodagem

DNIT: Departamento Nacional de Infra-estrutura de Transportes

DSR: $\quad$ Dynamic Shear Rheometer

DTM: $\quad$ Densidade teórica máxima medida 
DTT: $\quad$ Direct tensión tester

E: $\quad$ Estabilidade

EESC-USP: Escola de Engenharia de São Carlos - Universidade de São Paulo

ELSYM 5: $\quad$ Elastic Layered System 5

EP-USP: $\quad$ Escola Politécnica - Universidade de São Paulo

ESALs: $\quad$ Equivalent Single Axle Loads

ESSO: $\quad$ International Petroleum Company

EUA: $\quad$ Estados Unidos de América

EVA: $\quad$ Etileno Acetato de Vinila

f: $\quad$ Freqüência de aplicação de carga

F: $\quad$ Fluência

FAA: $\quad$ fine aggregate angularity

FHWA: $\quad$ Federal Highway Administration

H: $\quad$ Altura do corpo de prova

IBP: $\quad$ Instituto Brasileiro de Petróleo

ICM: $\quad$ Integrated Climatic Model

IPR/DNER: Instituto de Pesquisa Rodoviária do Departamento Nacional de Estradas de Rodagem

Lat: $\quad$ Latitude

LTT: $\quad$ Laboratory Test Track

LTPP: $\quad$ Long-Term Pavement Performance

LVDT: $\quad$ Linear Variable Differential Transducters

m: $\quad$ Módulo de relaxação

MPa: $\quad$ Mega Pascales

MR: $\quad$ Módulo de Resiliência 
MRR: Relação do Módulo de Resiliência

MR/RT: Relação entre Módulo de Resiliência e Resistência à Tração

MRu: $\quad$ Módulo de Resiliência após Umidade Induzida

N: $\quad$ Número de aplicações de carga na ruptura no ensaio de fadiga

NBR: $\quad$ Norma Brasileira

PAV: $\quad$ Pressure Aging Vessel

PEN: $\quad$ Penetração

PETROPERU: Petróleos del Perú

PG: $\quad$ Performance Grade

RBV: $\quad$ Relação Betume Vazios

rpm: $\quad$ Rotações por minuto

RT: $\quad$ Resistência à Tração

RTu: $\quad$ Resistência à Tração após umidade induzida

RTFOT: $\quad$ Rolling Thin Film Oven Test

RTR: $\quad$ Resistência à Tração Retida

RV: $\quad$ Rotational Viscometer

S: $\quad$ Módulo de rigidez estática

SBR: $\quad$ Styrene Butadiene Rubber

SBS: $\quad$ Styrene Butadiene Styrene

SENAMHI: $\quad$ Servicio Nacional de Meteorologia e Hidrologia - Perú

SHRP: $\quad$ Strategic Highway Research Program

SMA: $\quad$ Stone Matrix Asphalt

SMP: $\quad$ Seasonal Monitoring Program

SUPERPAVE: Superior Performing Asphalt Pavement System

SSD: $\quad$ Saturada Seca Superfícialmente 
STT: Departamento de Engenharia de Transportes

T: $\quad$ Temperatura

TDM: $\quad$ Tecnologia de Materiales

TF: $\quad$ Teor de filer

USA: $\quad$ United State of America

VAM: Vazios no Agregado Mineral

VFA: $\quad$ Void Filled with Asphalt 


\section{Lista de Símbolos}

\begin{tabular}{|c|c|}
\hline Abs asf & Absorção de asfalto \\
\hline$\delta$ & Ângulo de fase \\
\hline$\Delta$ & Deformação elástica ou resiliente \\
\hline$\Delta \sigma$ & Diferença de tensões no centro do corpo de prova \\
\hline$\Delta \mathrm{t}$ & Tempo de atraso \\
\hline$\varepsilon_{\mathrm{t}}$ & Deformação recuperável \\
\hline$\varepsilon_{\mathrm{i}}$ & Deformação resiliente \\
\hline $\mathrm{G}_{\mathrm{mb}}$ & Densidade aparente da mistura \\
\hline $\mathrm{G}_{\mathrm{mm}}$ & Densidade teórica máxima medida da mistura \\
\hline $\mathrm{G}_{\mathrm{sa}}$ & Densidade real dos agregados \\
\hline $\mathrm{G}_{\mathrm{sb}}$ & Densidade aparente dos agregados \\
\hline $\mathrm{G}_{\mathrm{sb}}(\mathrm{SSD})$ & Densidade aparente dos agregados (saturada seca superfícialmente) \\
\hline $\mathrm{G}_{\mathrm{se}}$ & Densidade efetiva dos agregados \\
\hline $\mathrm{G}^{*}$ & Módulo Complexo \\
\hline Mágua & Massa do corpo de prova imerso em água \\
\hline $\mathrm{M}_{\mathrm{ar}}$ & Massa do corpo de prova ao ar \\
\hline $\mathrm{N}_{\text {ini }}$ & Número inicial de giros \\
\hline $\mathrm{N}_{\max }$ & Número máximo de giros \\
\hline $\mathrm{N}_{\text {projeto }}$ & Número de giros de projeto \\
\hline $\mathrm{P}_{\mathrm{b}}$ & Teor de asfalto \\
\hline$P_{b e}$ & Teor efetivo de asfalto no Superpave \\
\hline$\rho_{\mathrm{b}}$ & Densidade do asfalto \\
\hline$\rho_{\mathrm{ef}}$ & Densidade efetiva da mistura \\
\hline
\end{tabular}


$\sigma_{\mathrm{t}}$

$\sigma_{R}$

$\sigma_{\text {ar }}$

$\delta_{\text {Modelo }}$

$\mathrm{T}_{\mathrm{ar}}$

$\mathrm{T}_{\text {MÁX }}$

$\mathrm{T}_{\text {MÍN }}$

$\mathrm{T}_{\text {MAXar }}$

$\mathrm{T}_{\text {MINar }}$

v

$\mathrm{V}_{\mathrm{a}}$

$\mathrm{V}_{\mathrm{b}}$

$\mathrm{V}_{\mathrm{v}}$

$\omega$
Tensão de tração

Resistência à tração

Desvio padrão da média anual de 7 dias da temperatura do ar

Erro padrão do modelo

Temperatura do ar

Temperatura máxima do pavimento

Temperatura mínima do pavimento

Média das temperaturas máximas do ar em 7 dias consecutivos

Temperatura mínima do ar

Coeficiente de Poisson

Porcentagem de vazios da mistura

Volume de vazios preenchido pelo betume

Volume de vazios

Freqüência angular 


\section{ÍNDICE}

RESUMO..........................................................................................................................................ii

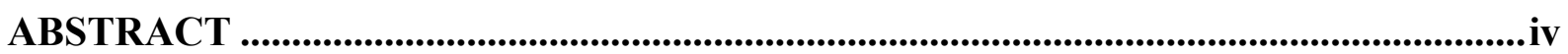

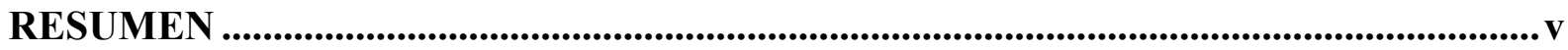

Lista de Figuras ........................................................................................................................ vi

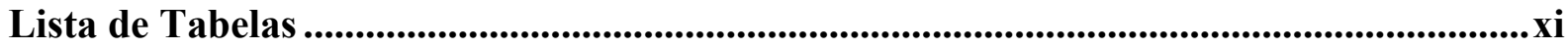

Lista de Abreviaturas e Siglas ..........................................................................................

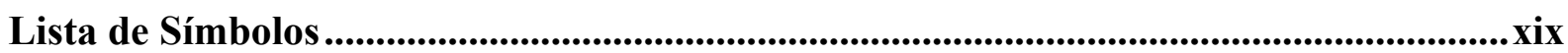

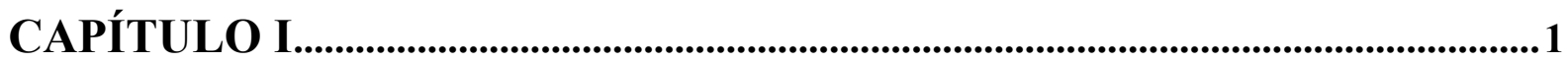

1. INTRODUÇÃ

1.1 EVOLUÇÃO E DESENVOLVIMENTO DA PAVIMENTAÇÃO ASFÁLTICA NO PERU.. 1

1.2 PROBLEMAS DE DESEMPENHO DO ASFALTO …........................................ 4

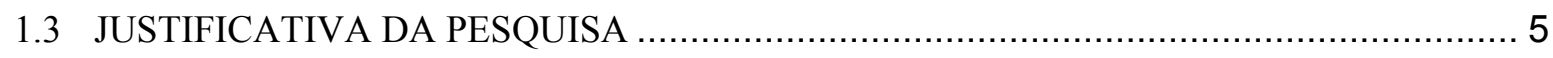

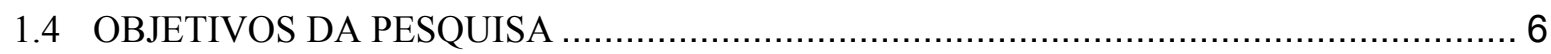

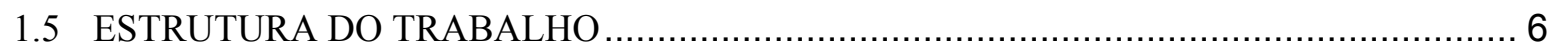

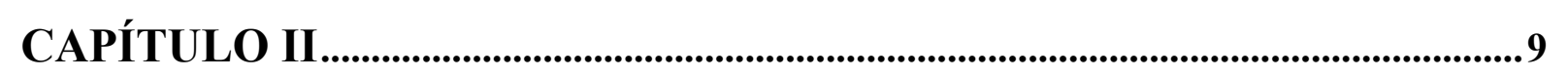

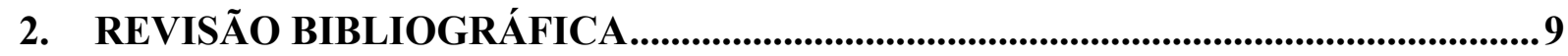

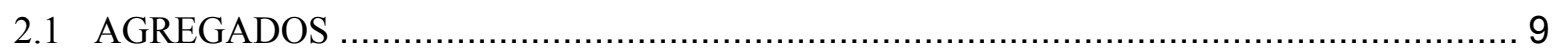

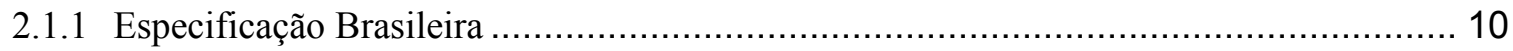

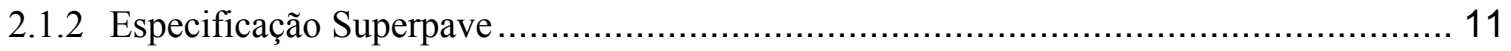

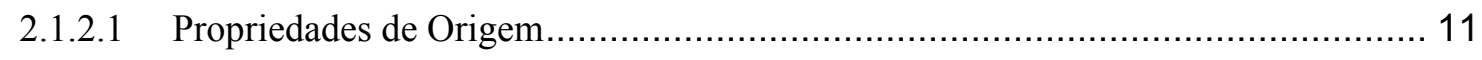

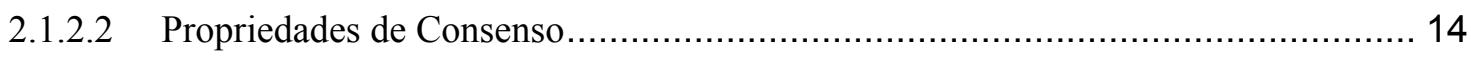




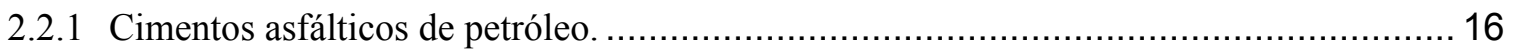

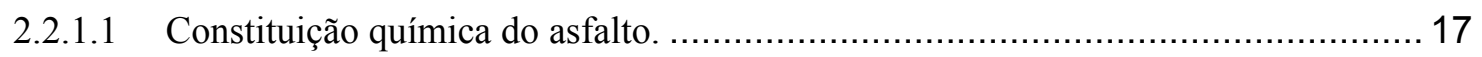

2.2.1.2 Relação entre composição química e propriedades físicas do asfálto...................... 18

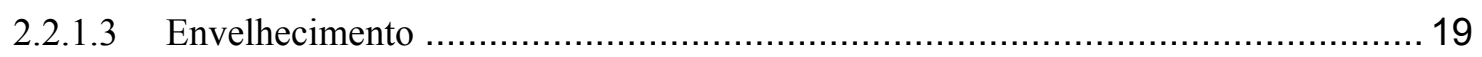

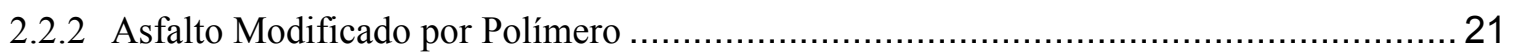

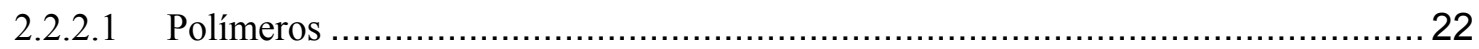

2.2.2.2 Propriedades Modificadoras dos Polímeros ........................................................... 23

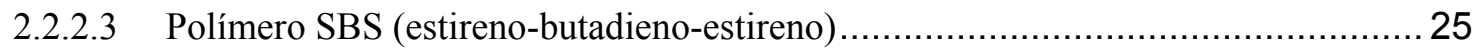

2.2.2.4 Vantagens técnicas dos asfaltos modificados por polímeros ............................ 26

2.2.2.5 Processo de incorporação e mecanismo de modificação do asfalto com polímero SBS

2.2.2.6 Produção do asfalto modificado por polímero …................................................ 31

2.2.2.7 Histórico do uso do asfalto modificado com polímero ........................................... 34

2.2.2.8 Histórico no Brasil sobre o estudo e aplicação do asfalto modificado com polímero

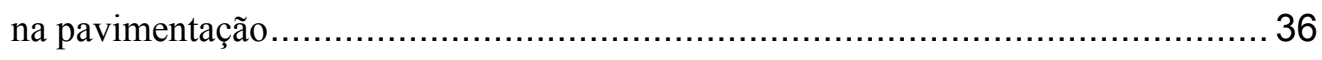

2.2.3 Cimentos asfálticos de petróleo, Especificação Brasileira ........................................ 37

2.2.4 Cimentos asfálticos de petróleo, Especificação Americana (Superpave) ......................... 38

2.2.5 Análise comparativa da caracterização e classificação dos asfaltos por penetração e pelo

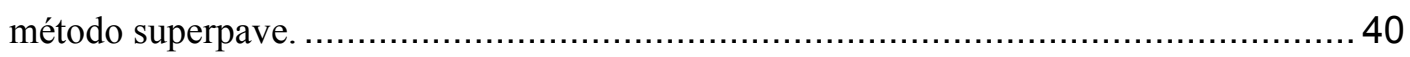

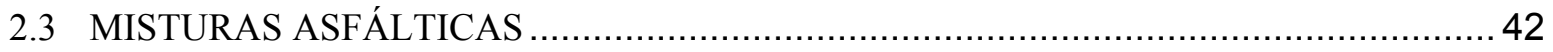

2.3.1 Distribuição granulométrica das misturas asfálticas............................................... 42

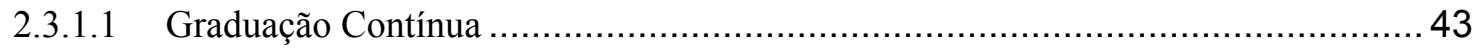

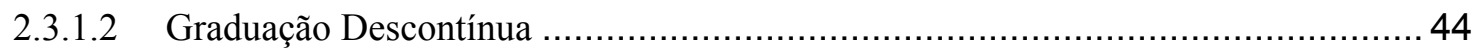

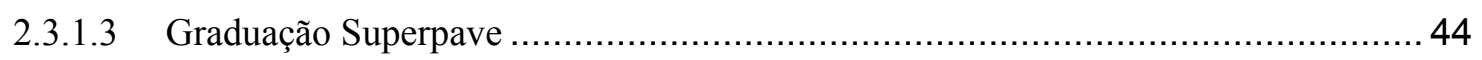

2.3.1.4 Influência da graduação no Desempenho de Misturas Asfálticas ......................... 47

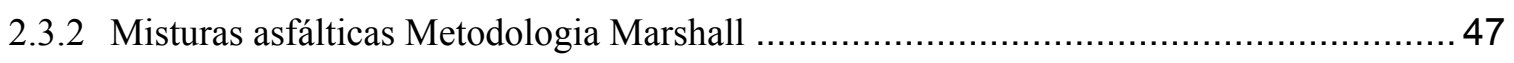

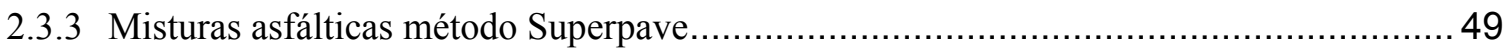


2.3.4 Requisitos volumétricos da mistura 51

2.4 PRINCIPAIS DEFEITOS DE UM PAVIMENTO FLEXÍVEL 54

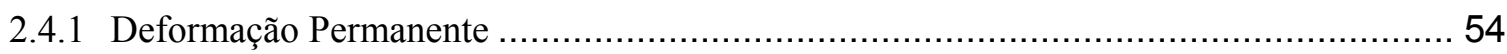

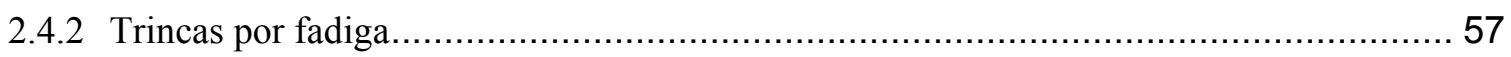

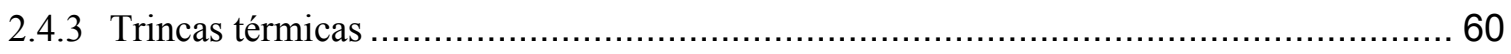

CAPÍTULO III. 63

3. ESTUDO E DISTRIBUIÇÃO DO GRAU DE DESEMPENHO DE LIGANTES

ASFÁLTICOS DO PERU. 63

3.1 CONSIDERAÇÕES INICIAIS 63

3.2 ALGUMAS CONSIDERAÇÕES SOBRE O ESTUDO E SELEÇÃO DO GRAU DE DESEMPENHO DO LIGANTE ASFÁLTICO PROPOSTAS PELO SHRP 64

3.2.1 Temperaturas do ar $\left(\mathrm{T}_{\mathrm{XXar}} \mathrm{e} \mathrm{T}_{\mathrm{YYar}}\right)$ 65

3.2.2 Temperaturas do Pavimento ( $\mathrm{T}_{\mathrm{MAX}}$ e $\left.\mathrm{T}_{\mathrm{MIN}}\right)$..... 66

3.2.3 Efeito do Tráfego: Velocidade de Carga e Tráfego Acumulado .................................. 70

3.2.4 Seleção do grau PG por programas computacionais ............................................. 71

3.3 DADOS E CONSIDERAÇÕES PARA A SELEÇÃO DO PG DO LIGANTE ASFÁLTICO 72

3.3.1 Metodologia de cálculo do Grau de desempenho do ligante asfáltico (PG) .................. 73

3.3.2 Seleção do PG do ligante asfáltico a ser produzido .............................................. 75

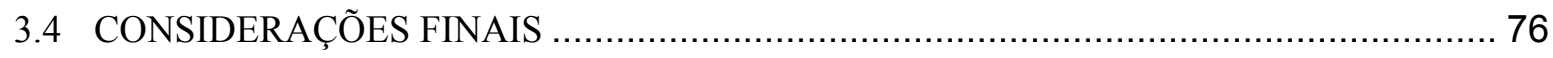

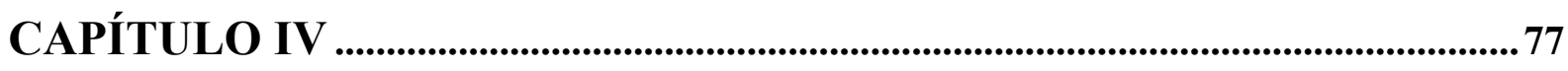

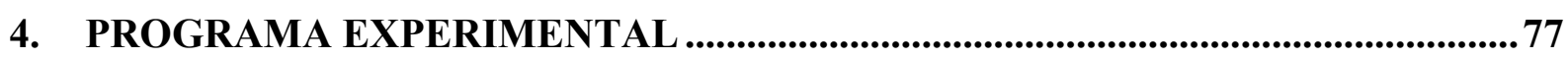

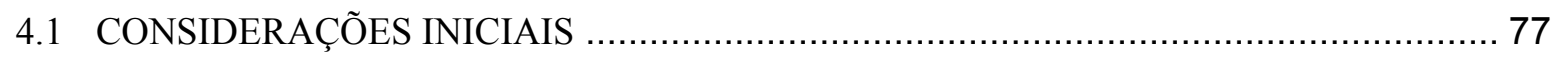

4.2 ESTUDO E CARACTERIZAÇÃO DOS MATERIAIS ….......................................... 77

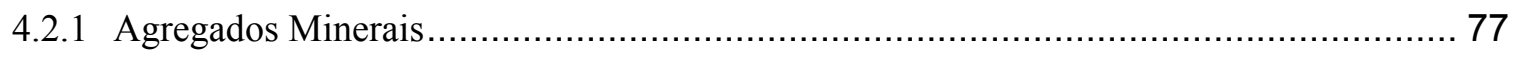

4.2.1.1 Ensaios para determinação das propriedades dos agregados................................ 78 
4.2.2.1 Ensaios para determinação das propriedades dos ligantes asfálticos......................90

4.2.2.2 Correlações com as propriedades mecânicas ..................................................... 104

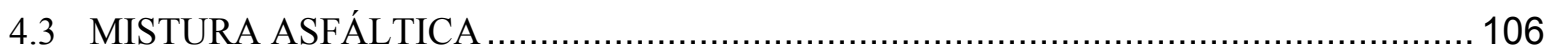

4.3.1 Composição granulométrica da Mistura ............................................................ 106

4.3.1.1 Seleção e preparação dos agregados minerais ................................................. 107

4.3.1.2 Dosagem da mistura Betuminosa .............................................................. 108

4.3.2 Temperaturas de usinagem e compactação da mistura asfáltica ................................. 110

4.3.3 Determinação do teor de projeto - Método Marshall ............................................. 114

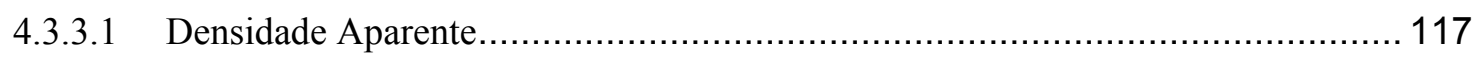

4.3.3.2 Densidade Máxima Teórica (Método Rice) ................................................... 118

4.3.3.3 Absorção de asfalto pelo agregado ...................................................... 119

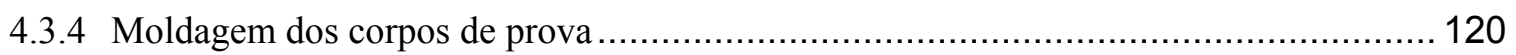

4.3.5 Ensaios para determinação das propriedades das misturas asfálticas........................... 122

4.3.5.1 Estabilidade e fluência Marshall ................................................................. 123

4.3.5.2 Ensaio de Módulo de Resiliência ......................................................... 124

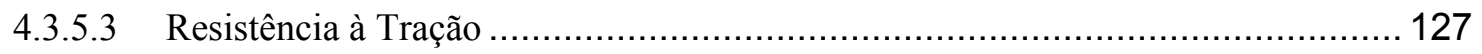

4.3.5.4 Resistência à tração retida por umidade induzida ...................................... 129

4.3.5.5 Fluência por Compressão Uniaxial Estática (“creep estático”) ........................... 131

4.3.5.6 Fluência por Compressão Uniaxial Dinâmica (“creep dinâmico”) ....................... 135

4.3.5.7 Ensaio de Fadiga por compressão diametral ............................................. 138

4.3.6 Programa computacional para controle dos ensaios de módulo de resiliência, fluência por compressão uniaxial estática, fluência por compressão diametral dinâmica e fadiga. .... 142

5. APRESENTAÇÃO E ANÁLISE DOS RESULTADOS DE LABORATÓRIO ..... 143

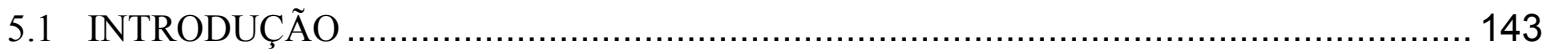




\subsection{DISTRIBUIÇÃO DO GRAU DE DESEMPENHO DE LIGANTES ASFÁLTICOS DO PERU}

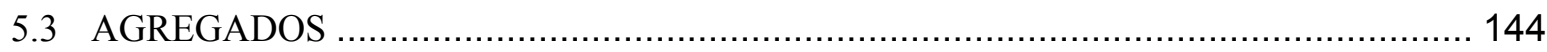

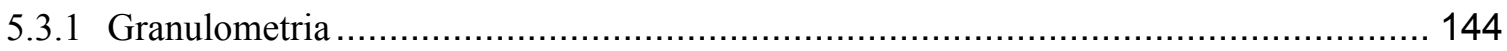

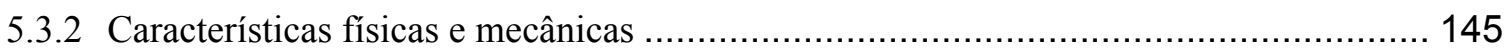

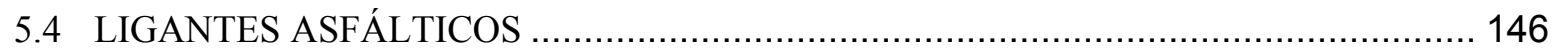

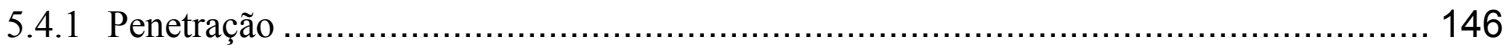

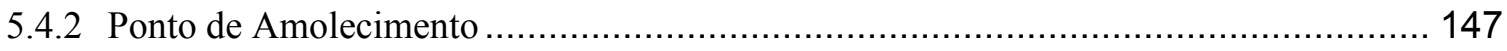

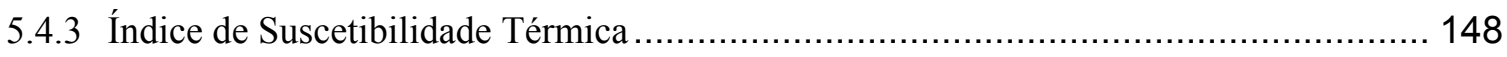

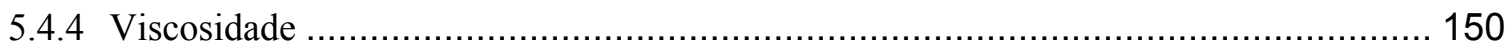

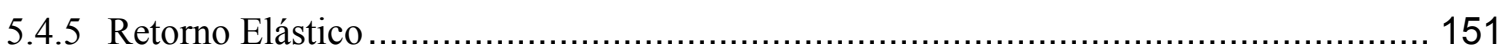

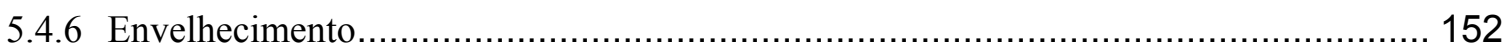

5.4.7 Efeito do ligante no desempenho da mistura.......................................................... 152

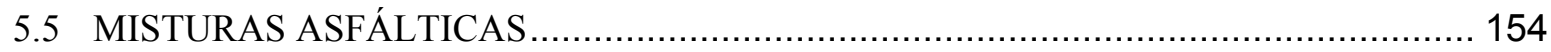

5.5.1 Estimativa do teor de projeto dos ligantes asfálticos .......................................... 154

5.5.2 Estimativa da densidade máxima teórica (Método Rice) ......................................... 157

5.5.3 Ensaio de estabilidade e fluência Marshall ..................................................... 158

5.5.3.1 Ensaios de Estabilidade e Fluência Marshall para misturas sem envelhecimento . 158

5.5.3.2 Ensaios de Estabilidade e Fluência Marshall para misturas com envelhecimento em

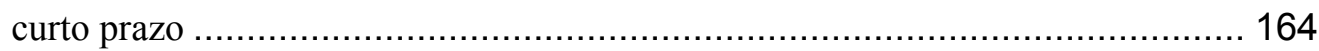

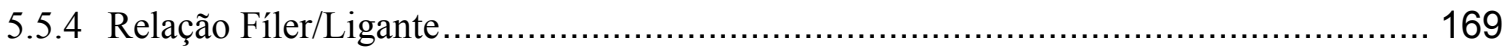

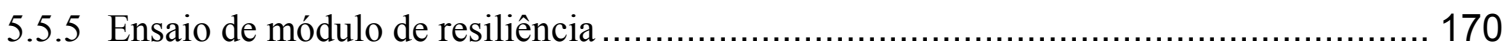

5.5.6 Ensaio de resistência à tração por compressão diametral.......................................... 173

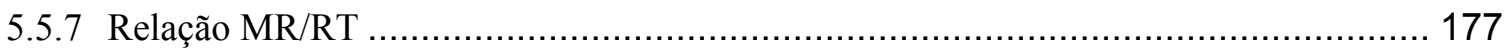

5.5.8 Ensaio de resistência à tração retida por umidade induzida ..................................... 180

5.5.9 Ensaio de fluência por compressão uniaxial estática (“creep estático”) ....................... 183

5.5.10 Ensaio de fluência por compressão uniaxial dinâmica (“creep dinâmico")................... 190

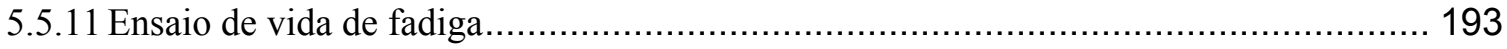


5.5.12 Análise Mecanística da influência do tipo de ligante e do envelhecimento de curto prazo na vida de fadiga 207

CAPÍTULO VI. 213

6. CONCLUSÕES E RECOMENDAÇÕES ........................................................ 213

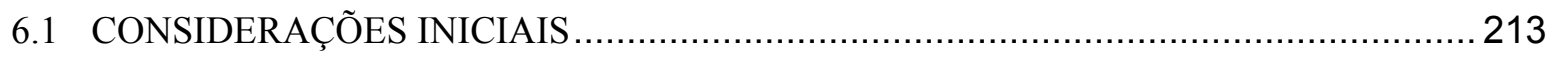

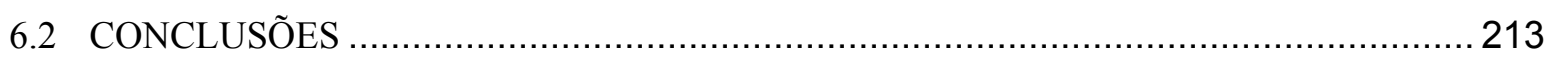

6.2.1 Quanto ao estudo e distribuição do grau de desempenho de ligantes asfálticos do Peru. 213

6.2.2 Quanto aos resultados dos ensaios nos ligantes asfálticos.....................................2 214

6.2.3 Quanto aos resultados dos ensaios nas misturas asfálticas ....................................... 214

6.2.4 Quanto aos resultados da análise mecanística ................................................... 215

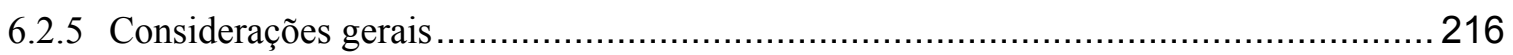

6.3 RECOMENDAÇÕES PARA PESQUISAS FUTURAS …................................... 216

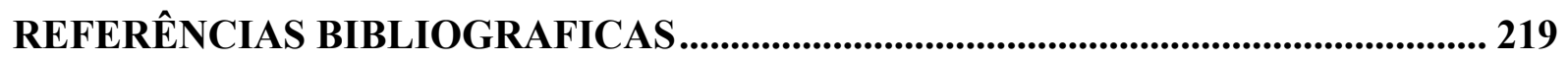




\section{CAPÍTULO I}

\section{INTRODUÇÃO}

\subsection{EVOLUÇÃO E DESENVOLVIMENTO DA PAVIMENTAÇÃo ASFÁLTICA NO PERU}

No período entre 1935 e 1940, aproximadamente, usava-se no Peru, um ligante betuminoso constituído por pó asfáltico mais um solvente (fluxol), denominado polvofluxol, que era transportado, distribuído e compactado com rolo. Esse sistema foi abandonado por ser prejudicial à saúde, por causar doenças pulmonares e até mesmo levar à morte dos operários.

O sistema polvofluxol foi substituído pelo asfalto diluído $\mathrm{RC}-250$ (Cut back ou asfalto recortado). No Peru, no Departamento de "Piura", Província de "Talara", em 1938 instalou-se a primeira planta de asfaltos, sob a direção da International Petroleum Company -ESSO, que utilizava petróleo peruano dos Campos da "Brea"e "Parinas" para a produção do RC-250. O asfalto diluído tinha uma composição aproximada de $87 \%$ de cimento asfáltico e $13 \%$ de solvente.

No ano de 1961, em razão da alta demanda de asfalto nas regiões centro e sul, instala-se em Lurin - Lima outra produtora de asfaltos, a Refinaria "Conchan", sob a direção da Fluor Corporation, do Canadá, que acabou sendo inaugurada pela Companhia Chevron da Califórnia - USA. Desde então, as empresas privadas de engenharia popularizaram a "mistura asfáltica a quente", com cimento asfáltico PEN 60/70. 
Em 1969, foi criada a PETROPERU S.A. (Petróleos del Peru), a mesma que administra até hoje as duas Refinarias antes mencionadas, com maior experiência na produção de cimentos asfálticos, asfaltos diluídos e de uso industrial, que são elaborados com petróleo peruano e que são utilizados na totalidade das rodovias do Peru.

Hoje em dia, o Peru tem sete refinarias, conforme apresentado na Figura 1.1, das quais as refinarias de "Conchan" e "Talara", administradas pela PETROPERU S. A., produzem os seguintes tipos de asfaltos de petróleo:

- Asfaltos Diluídos Tipo RC e MC;

- Cimentos asfálticos: PEN 10-20, PEN 40-50, PEN 60-70, PEN 85-100 e PEN 120-150.

No final de 2005 a empresa Tecnologia de Materiais (TDM), em parceria com a Ipiranga Asfaltos do Brasil, iniciou a produção de Asfalto modificado por Polímero (AMP), tendo como matéria prima o cimento asfáltico de petróleo PEN 60/70 e o copolímero em bloco Styrene Butadiene Styrene (SBS), com o nome comercial de asfalto modificado por polímero SBS Betuflex tipo I 60/60.

Os ligantes asfálticos mais utilizados nas obras rodoviárias são o PEN 60-70 e o PEN 85-100. Com o asfalto modificado por polímero SBS Betuflex tipo I 60/60 ainda não se tem experiência de utilização em obra, por ser um produto novo no mercado peruano.

Com relação ao método de projeto de misturas asfálticas, usa-se, no Peru, o Marshall, que é de utilização mundial, tomando-se em consideração também os requisitos do Instituto do 
Asfalto e da American Association of State Highway and Transportation Officials (AASHTO).

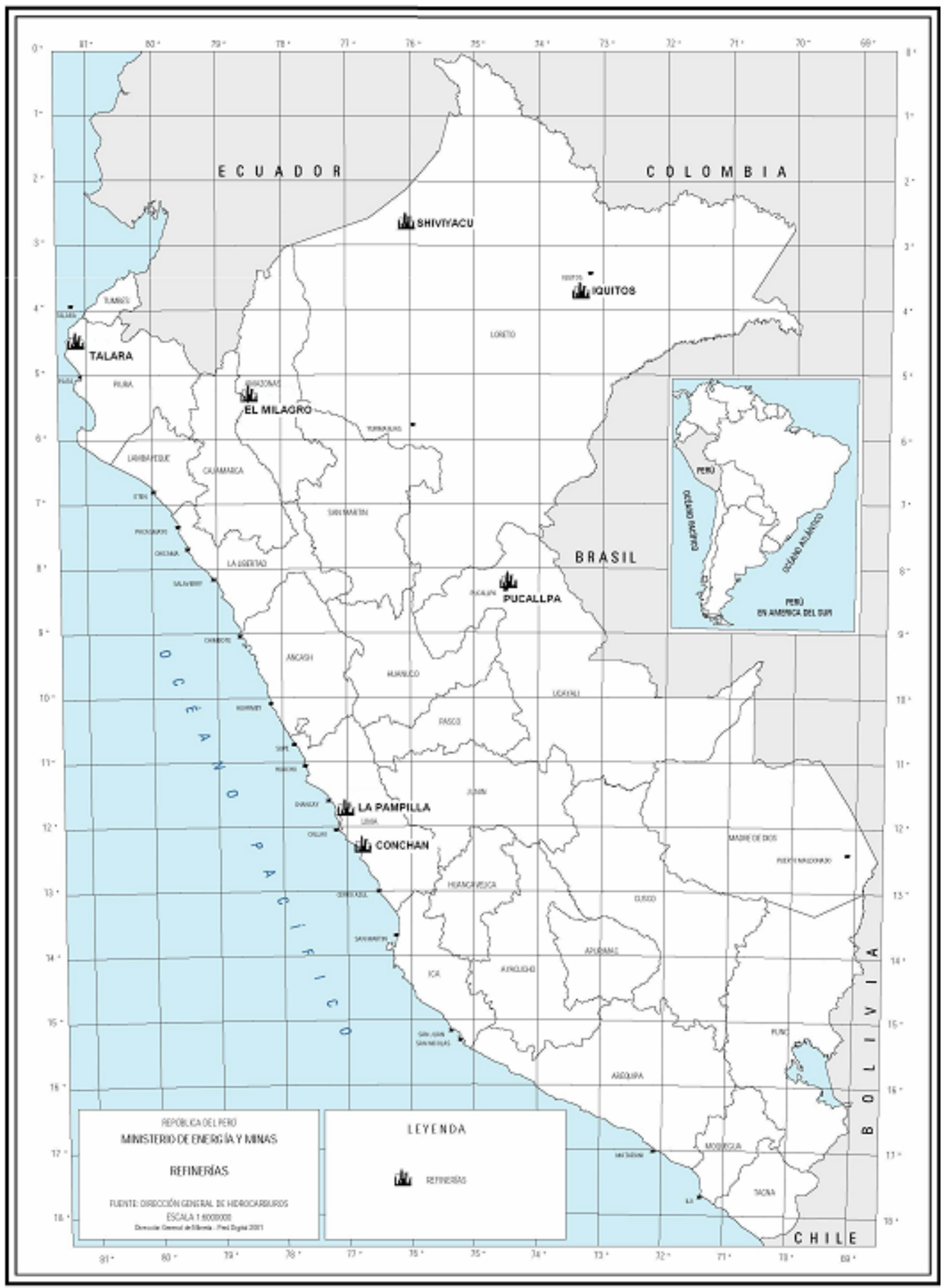

Figura 1.1 - Mapa de localização de Refinarias de petróleo do Peru.

Fonte: http://www.minem.gob.pe/ministerio/pub atlas2001.asp (Data de acesso: Maio 2006) 


\subsection{PROBLEMAS DE DESEMPENHO DO ASFALTO}

O desempenho das misturas asfálticas destinadas à pavimentação dependem amplamente das propriedades e proporções relativas dos seus principais componentes, que são os agregados minerais, o cimento asfáltico e os vazios. A função do cimento asfáltico numa mistura é manter o esqueleto mineral consolidado, com a finalidade de suportar a ação do tráfego.

O cimento asfáltico deve ser o suficientemente aglutinante para manter a adesão do sistema agregado/ligante e, ao mesmo tempo, a resistência ao cisalhamento provocado pelas cargas do tráfego, especialmente em misturas asfálticas abertas, nos pontos de contado dos agregados. Deve ser, sob altas temperaturas, suficientemente rígido para não apresentar deformação permanente, e flexível o suficiente para resistir às trincas por fadiga e térmica em baixas temperaturas, em razão que as misturas asfálticas sofrem influência significativa pois o Cimento Asfáltico de Petróleo (CAP), por ser um material visco-elástico, é sensível às variações climáticas.

Dessa forma, sob baixas temperaturas, as misturas asfálticas são susceptíveis ao aparecimento de trincas devido ao enrijecimento do CAP, ao passo que sob altas temperaturas as misturas asfálticas ficam sujeitas ao aparecimento de deformações permanentes nas trilhas de roda em razão da diminuição da rigidez do CAP.

Uma alternativa para que os pavimentos possam suportar as variações climáticas, assim como as crescentes solicitações do tráfego, é o emprego de asfaltos de alto desempenho, destacando-se, entre eles, os asfaltos modificados por polímero SBS. A função básica de um polímero, quando adicionado ao asfalto, é reduzir a susceptibilidade térmica, melhorando o 
comportamento elástico do asfalto e proporcionando o aumento da resistência à deformação permanente das misturas asfálticas em situações extremas de altas temperaturas em serviço, a diminuição das trincas em baixas temperaturas e a diminuição das trincas por fadiga. Os polímeros também melhoram a adesividade entre os agregados e o asfalto, diminuindo a abrasão e melhorando a resistência à oxidação.

O uso de asfaltos modificados por polímeros contribui para o desenvolvimento de novas técnicas construtivas em pavimentação, como revestimentos constituídos de misturas asfálticas especiais, com utilização de uma composição granulométrica dos agregados pétreos bastante particulares, não obedecendo à clássica mistura de granulometria contínua, mas formada por uma composição descontínua como o Stone Matrix Asphalt (SMA), revestimentos drenantes ou camada porosa de atrito, camadas impermeabilizantes ou membranas anti-reflexão de trincas e camadas de impermeabilização em pontes.

\subsection{JUSTIFICATIVA DA PESQUISA}

O desenvolvimento da pavimentação no Peru é baseado nos revestimentos asfálticos, que constituem quase $98 \%$ dos pavimentos rodoviários e urbanos. Porém, com as técnicas tradicionais em prática, a pavimentação asfáltica, em alguns casos, não tem atendido aos requisitos de resistência e durabilidade, apresentando problemas precoces de trincamento por fadiga, trincamento por gradientes térmicos, desagregação do revestimento asfáltico, afundamento de trilha de roda, entre outros.

Devido aos fatores citados, os asfaltos modificados por polímeros representam uma opção para que se consiga uma maior durabilidade dos pavimentos peruanos, o que num país onde 
há uma inquestionável descontinuidade de políticas de transportes, representa a possibilidade da infra-estrutura de transportes sobreviver aos períodos de "entressafra" de investimentos, minimizando a possibilidade de depreciação de um dos maiores patrimônios nacionais, que são as rodovias.

\subsection{OBJETIVOS DA PESQUISA}

Tomando em consideração os problemas de desempenho das misturas asfálticas convencionais e as potenciais melhorias de desempenho que os asfaltos modificados fornecem, este trabalho tem como objetivos:

- Avaliar o comportamento das misturas asfálticas peruanas produzidas com asfalto convencional (PEN 60/70) e com asfalto modificado por polímero SBS (Betuflex tipo I 60/60), do qual ainda não se tem resultados de uso em obra, por ser um produto novo no mercado peruano;

- Estabelecer a distribuição de Grau de Desempenho (PG) de ligantes asfálticos do Peru com base nas condições climáticas de cada região e dar diretrizes para a produção de um ligante asfáltico capaz de atender às condições climáticas e de tráfego do Peru. Em seqüência à produção, que será realizada por uma empresa especializada em asfaltos modificados por polímero, em colaboração à presente pesquisa, será avaliado o comportamento de misturas asfálticas produzidas com esse ligante asfáltico.

\subsection{ESTRUTURA DO TRABALHO}

O trabalho foi dividido em 6 capítulos conforme descrito nos tópicos abaixo: 
- Capítulo I: Apresenta uma perpectiva geral da pavimentação asfáltica do Peru, os problemas dos pavimentos asfálticos, bem como os objetivos da disertação.

- Capítulo II: Apresenta uma revisão bibliográfica dos agregados, ligantes asfálticos convencionais, asfaltos modificados por polímeros, processo de produção de asfaltos modificados por polímeros, vantagens do uso em obras rodoviárias e os métodos de dosagem de misturas asfálticas Marshall e Superpave.

- Capítulo III: Aborda o estudo e distribuição do grau de desempenho de ligantes asfálticos do Peru baseado no programa SHRP e no LTPP Bind, onde é determinado o mapa de distribuição de grau de desempenho PG de ligantes asfálticos do Peru com $98 \%$ de confiabilidade.

- Capítulo IV: Apresenta o programa experimental de laboratório, materiais utilizados nesta pesquisa, agregados (Pedra 1, Pedrisco, Pó de pedra) e ligantes asfálticos (CAP PEN 60/70, AMP tipo I 60/60 e AMP PG 76 -22), caracterização desses materiais pelo método convencional e Superpave e um resumo dos procedimentos de ensaio realizados em agregados, ligantes e misturas asfálticas.

- Capítulo V: Apresenta os resultados do programa experimental e a análise dos resultados dos ensaios realizados em laboratório, para os três ligantes asfálticos utilizados nas três condições de envelhecimento. Os resultados são apresentados em forma de tabelas e gráficos.

- Capítulo VI: Apresenta as principais conclusões e os comentários finais, assim como sugestões para trabalhos futuros. 


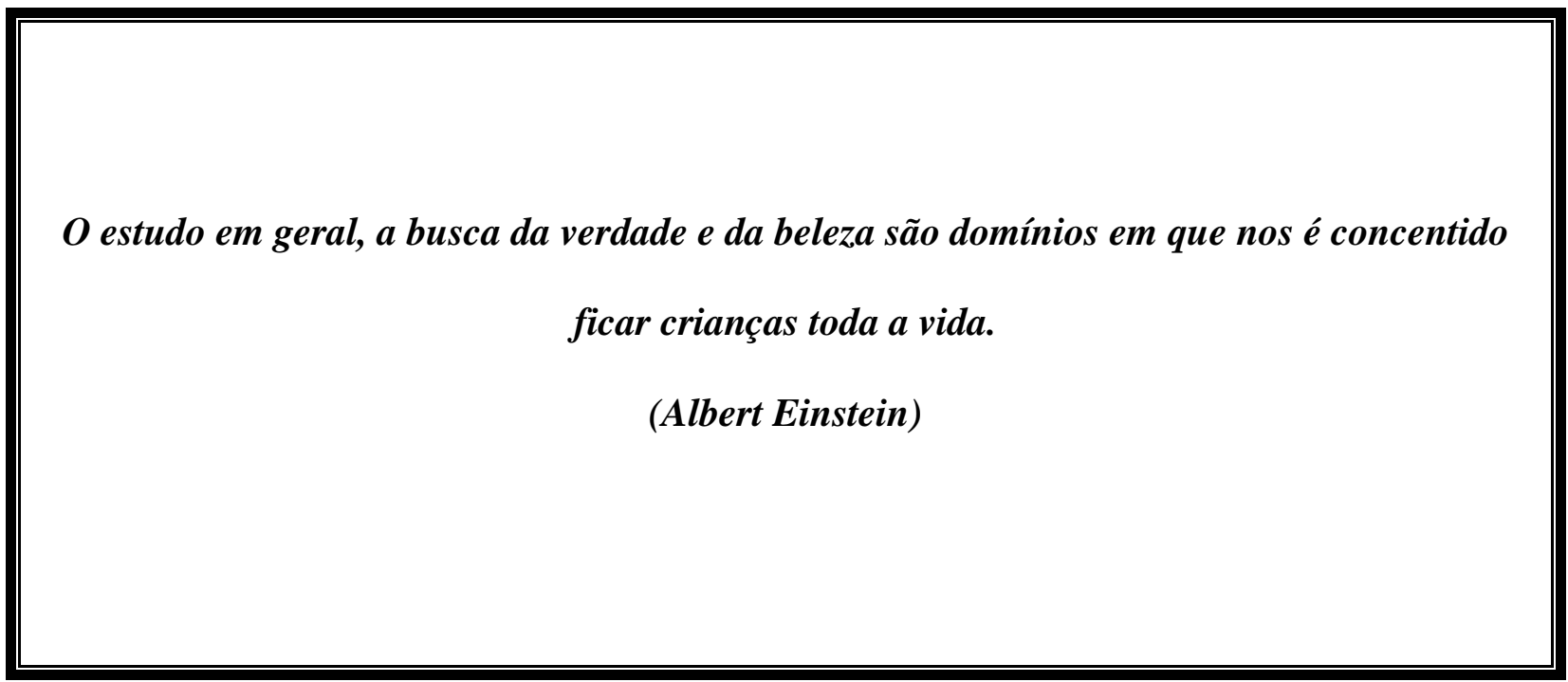




\section{CAPÍTULO II}

\section{REVISÃO BIBLIOGRÁFICA}

\subsection{AGREGADOS}

Os agregados podem ser classificados segundo sua natureza, tamanho e graduação:

- Natureza:

Agregado natural: constituídos de grãos oriundos da alteração das rochas pelos processos de intemperismo ou produzidos por britagem: pedregulhos, seixos, britas, areias etc.

Agregado artificial: produtos ou subprodutos de processo industrial por transformação física e química do material: escória de alto forno, argila calcinada, argila expandida.

\section{- Tamanho:}

Agregado graúdo: material retido na peneira $\mathrm{n}^{\circ} 4(4,75 \mathrm{~mm})$ : britas, cascalhos, seixos etc.

Agregado miúdo: material que passa na peneira $\mathrm{n}^{\circ} 4(4,75 \mathrm{~mm})$ e fica retido na peneira $n^{\circ} 200(0,075 \mathrm{~mm})$ : pó de pedra, areia etc.

Fíler (material de enchimento): material que passa pelo menos $65 \%$ na peneira $\mathrm{n}^{\mathrm{o}} 200$ (0,075mm): cal extinta, cimento Portland, pó de chaminé etc. 
- Graduação:

Agregado de graduação densa: apresenta uma curva granulométrica continua, representativa de material bem graduado e com quantidade de material fino suficiente para preencher os vazios entre as partículas maiores.

Agregado de graduação aberta: apresenta uma curva granulométrica, de material mal graduado, com insuficiência de material fino, para preencher os vazios entre as partículas maiores.

\subsubsection{Especificação Brasileira}

Segundo o DNER (DNER-ES 313/97), os agregados para uso em Concreto Betuminoso devem apresentar as seguintes características:

- Agregado graúdo - deve ser constituido de fragmentos sãos, duráveis, livres de torrões de argila, e substâncias nocivas. Deve atender aos seguintes parâmetros:

Desgaste Los Angeles igual ou inferior a 40\% (DNER-ME 035/98);

Índice de forma superior a 0,5 (DNER-ME 086/94);

Durabilidade inferior a 12\% (DNER-ME 089/94).

- Agregado miúdo - as partículas individuais deverão ser resistentes, apresentar moderada angularidade, e estarem livres de torrões de argila e de substâncias nocivas. Equivalente Areia igual ou superior a 55\% (DNER-ME 054/97).

- Material de enchimento - quando da aplicação deverá estar seco e isento de grumos. Deve atender à granulometria apresentada na Tabela 2.1 (DNER-EM 367/97): 
Tabela 2.1 - Especificação granulométrica para material de enchimento ou filer.

\begin{tabular}{cc}
\hline Abertura de malha (mm) & \% em peso passado \\
\hline $0,42 \mathrm{~mm}$ & 100 \\
$0,18 \mathrm{~mm}$ & $95-100$ \\
$0,075 \mathrm{~mm}$ & $65-100$ \\
\hline
\end{tabular}

Fonte: DNER-EM 367/97

São especificadas três faixas granulométricas, A, B e C (DNER ES-313/97), numa das quais deve ser enquadrada a mistura de agregados em cada dosagem, em função da aplicação como camada de rolamento ou de ligação.

\subsubsection{Especificação Superpave}

Os pesquisadores do Programa Estratégico de Pesquisa Rodoviária (Strategic Highway Research Program - SHRP) concluíram que os agregados possuem fundamental importância nas propriedades do Concreto Betuminoso Usinado a Quente (CBUQ). Embora não tenham desenvolvido nenhum procedimento novo para a avaliação dos agregados, procedimentos já existentes foram refinados de modo a se adequarem ao sistema Superpave. São especificados dois tipos de propriedades de agregados no sistema Superpave, propriedades de origem e propriedades de consenso (MOTTA et al., 1996).

\subsubsection{Propriedades de Origem}

São aquelas propriedades que as agências usam regularmente para testar a qualidade das fontes dos agregados. O SHRP não especifica valores limites, porque essas são muito dependentes da fonte, mas recomenda que os organismos locais os definam para cada projeto especifico. São elas: 
- Dureza (AASHTO T 96): definida como o percentual em peso de material perdido durante o ensaio de Abrasão Los Angeles com agregado maior que 2,36mm. O ensaio indica a resistência à abrasão que os agregados devem possuir durante usinagem, compactação e serviço;

- Sanidade (AASHTO T 104): usada para estimar a resistência ao intemperismo, a sanidade é definida como o percentual em peso de material perdido durante tratamento com solução de sulfato de sódio ou de magnésio. O ensaio pode ser realizado para agregados miúdos e graúdos.

- Materiais deletérios (AASHTO T 112): é definido pelo percentual em peso de contaminantes nos agregados. Pode ser realizado em agregados miúdos e graúdos.

Para especificar a granulometria do agregado, o Superpave utiliza um gráfico onde no eixo das abscissas estão as aberturas das peneiras, em milímetro, elevadas à potência de 0,45 . Para que a graduação em estudo atenda aos critérios Superpave, a curva granulométrica deve passar entre os pontos de controle e fora da zona de restrição (Figura 2.1.). 


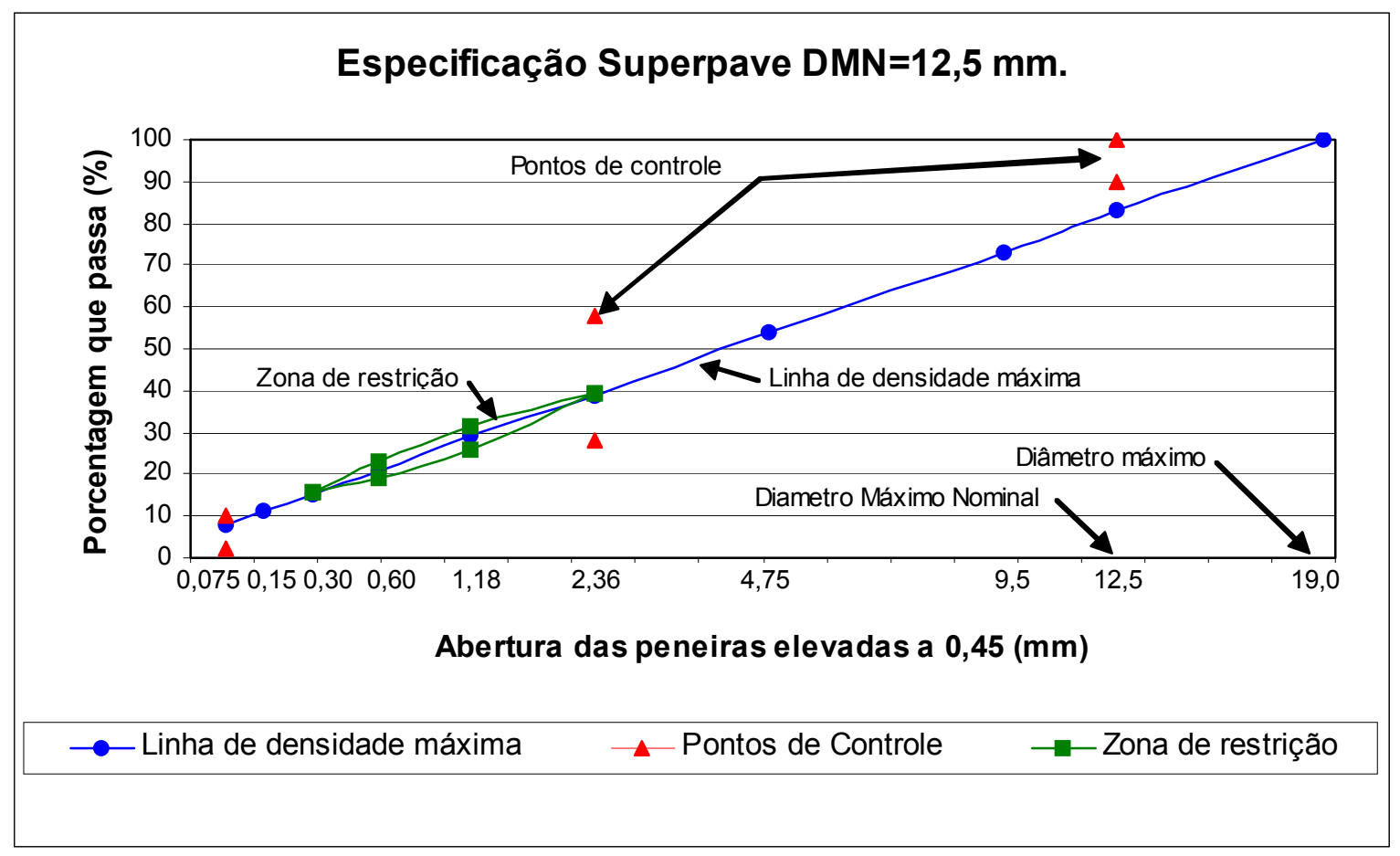

Figura 2.1 - Exemplo de granulometria Superpave para um Diâmetro Máximo Nominal de $12,5 \mathrm{~mm}$.

Os valores especificados são reproduzidos nas Tabelas 2.2 e 2.3, com várias faixas possíveis de enquadramento dos agregados (AASHTO MP 2-01).

Tabela 2.2 - Pontos de Controle conforme o Diâmetro Máximo Nominal.

\begin{tabular}{ccccccccccc}
\hline \multirow{2}{*}{$\begin{array}{c}\text { mbertura } \\
\mathbf{m m}\end{array}$} & \multicolumn{2}{c}{$\mathbf{3 7 , 5} \mathbf{~ m m}$} & \multicolumn{2}{c}{$\mathbf{2 5 , 0} \mathbf{~ m m}$} & \multicolumn{2}{c}{$\mathbf{1 9 , 0} \mathbf{~ m m}$} & \multicolumn{2}{c}{$\mathbf{1 2 , 5} \mathbf{~ m m}$} & \multicolumn{2}{c}{$\mathbf{9 , 5} \mathbf{~ m m}$} \\
\cline { 2 - 11 } & Min & Max & Min & Max & Min & Max & Min & Max & Min & Max \\
\hline 50 & 100 & - & - & - & - & - & - & - & - & - \\
37,5 & 90 & 100 & 100 & - & - & - & - & - & - & - \\
25 & - & 90 & 90 & 100 & 100 & - & - & - & - & - \\
19 & - & - & - & 90 & 90 & 100 & 100 & - & - & - \\
12,5 & - & - & - & - & - & 90 & 90 & 100 & 100 & - \\
9,5 & - & - & - & - & - & - & - & 90 & 90 & 100 \\
4,75 & - & - & - & - & - & - & - & - & - & 90 \\
2,36 & 15 & 41 & 19 & 45 & 23 & 49 & 28 & 58 & 32 & 67 \\
0,075 & 0 & 6 & 1 & 7 & 2 & 8 & 2 & 10 & 2 & 10 \\
\hline
\end{tabular}

Fonte: AASHTO MP 2-01 
Obs.: Diâmetro Máximo Nominal é definido como sendo um tamanho maior do que o primeiro tamanho da peneira que retém mais de $10 \%$.

Tabela 2.3 - Zona de restrição de acordo com o diâmetro máximo nominal.

\begin{tabular}{ccccccccccc}
\hline Abertura & \multicolumn{2}{c}{$\mathbf{3 7 , 5} \mathbf{~ m m}$} & \multicolumn{2}{c}{$\mathbf{2 5 , 0} \mathbf{~ m m}$} & \multicolumn{2}{c}{$\mathbf{1 9 , 0} \mathbf{~ m m}$} & \multicolumn{2}{c}{$\mathbf{1 2 , 5} \mathbf{~ m m}$} & \multicolumn{2}{c}{$\mathbf{9 , 5} \mathbf{~ m m}$} \\
\cline { 2 - 11 } $\mathbf{m m}$ & Min & Max & Min & Max & Min & Max & Min & Max & Min & Max \\
\hline 4,75 & 34,7 & 34,7 & 39,5 & 39,5 & - & - & - & - & - & - \\
2,36 & 23,3 & 27,3 & 26,8 & 30,8 & 34,6 & 34,6 & 39,1 & 39,1 & 47,2 & 47,2 \\
1,18 & 15,5 & 21,5 & 18,1 & 24,1 & 22,3 & 28,3 & 25,6 & 31,6 & 31,6 & 37,6 \\
0,6 & 11,7 & 15,7 & 13,6 & 17,6 & 16,7 & 20,7 & 19,1 & 23,1 & 23,5 & 27,5 \\
0,3 & 10 & 10 & 11,4 & 11,4 & 13,7 & 13,7 & 15,5 & 15,5 & 18,7 & 18,7 \\
\hline
\end{tabular}

Fonte: AASHTO MP 2-01

\subsubsection{Propriedades de Consenso}

São aquelas consideradas críticas para o desempenho adequado de um CBUQ. São ditas de “consenso" pois foram resultado de um amplo entendimento de diversos especialistas americanos, através da comparação entre os valores de especificações em uso. Os valores das propriedades de consenso variam de acordo com o nível de tráfego e a posição relativa da camada na estrutura do pavimento. Essas propriedades são:

- Angularidade do agregado graúdo (ASTM D 6821): definida como o percentual em peso de agregado graúdo, retido na peneira de abertura $4,75 \mathrm{~mm}$, que possua uma ou mais faces fraturadas. Quanto maior a angularidade do agregado graúdo, melhor, já que agregados de forma cúbica e com faces fraturadas apresentam uma maior resistência ao cisalhamento; 
- Angularidade do agregado miúdo (ASTM D 6821): definida como o percentual de vazios no agregado miúdo que passa na peneira de abertura 2,36 $\mathrm{mm}$. Quanto maior o teor de vazios, maior a quantidade de faces fraturadas no agregado;

- Partículas planas e alongadas (ASTM D 4791): definida como o percentual em peso de agregado graúdo, com relação entre a maior e a menor dimensão maior que 5. Lamelaridade alta indica a grande presença de partículas planas e alongadas, o que aumenta a tendência de quebra de agregados durante a compactação e vida em serviço do pavimento;

- Teor de finos (AASHTO T 176): é definido como o percentual em peso de material silte mais argila, passante na peneira de abertura $0,075 \mathrm{~mm}$ presente no agregado. Um grande teor de argila impregnado nos agregados dificulta a adesão do ligante ao agregado e deixa a mistura mais suscetível à ação da água.

A Tabela 2.4 reproduz os valores especificados na AASHTO MP 2-01 para essas propriedades de consenso.

Tabela 2.4 - Especificação SUPERPAVE: requisitos das propriedades de consenso.

\begin{tabular}{|c|c|c|c|c|c|c|}
\hline \multirow[t]{2}{*}{$\begin{array}{l}\text { Número } \\
\mathrm{N}^{\mathrm{a}}\left(10^{6}\right)\end{array}$} & \multicolumn{2}{|c|}{$\begin{array}{c}\text { Faces fraturadas Agregado } \\
\text { Graúdo } \\
(\%) \text { mínimo }\end{array}$} & \multicolumn{2}{|c|}{$\begin{array}{l}\text { Vazios não compactados } \\
\text { Agregado Fino } \\
\text { (\%) mínimo }\end{array}$} & \multirow[t]{2}{*}{$\begin{array}{l}\text { Equivalente } \\
\text { Areia } \\
(\%) \text { mínimo }\end{array}$} & \multirow{2}{*}{$\begin{array}{l}\text { Partículas } \\
\text { Planas e } \\
\text { Alongadas } \\
\text { (\%) máximo }\end{array}$} \\
\hline & $\leq 100 \mathrm{~mm}$ & $>100 \mathrm{~mm}$ & $\leq 100 \mathrm{~mm}$ & $>100 \mathrm{~mm}$ & & \\
\hline$<0,3$ & $55 /-$ & $-/-$ & - & - & 40 & - \\
\hline $0,3 a<3$ & $75 /-$ & $50 /-$ & 40 & 40 & 45 & 10 \\
\hline $3 a<10$ & $85 / 80^{\mathrm{b}}$ & $60 /-$ & 45 & 40 & 45 & \\
\hline $10 \mathrm{a}<30$ & $95 / 90$ & $80 / 75$ & 45 & 40 & 45 & \\
\hline$\geq 30$ & $100 / 100$ & $100 / 100$ & 45 & 45 & 50 & \\
\hline
\end{tabular}

a) Tráfego de projeto esperado na faixa de projeto para um período de 20 anos.

b) $85 / 80$ indica que $85 \%$ do agregado graúdo têm uma face fraturada e $80 \%$ tem duas ou mais faces fraturadas. 


\subsection{MATERIAIS BETUMINOSOS}

Define-se como betume a mistura de hidrocarbonetos pesados, obtidos em estado natural ou por diferentes processos físicos ou químicos, com seus derivados de consistência variável e com poder aglutinante e impermeabilizante, sendo completamente solúvel no bissulfeto de carbono $\mathrm{CS}_{2}$ (American Society for Testing and Materials - ASTM).

Atualmente, a maior parte do asfalto produzido e empregado no mundo é extraída do petróleo, do qual é obtida, isenta de impurezas, sendo quase completamente solúvel em bissulfeto de carbono ou tetracloreto de carbono (IBP, 1994).

\subsubsection{Cimentos asfálticos de petróleo}

Os cimentos asfálticos são obtidos pelo processo de destilação do petróleo cru através de diferentes técnicas de refinação. À temperatura ambiente, o cimento asfáltico é um semisólido escuro, pegajoso e um material altamente viscoso. É durável e tem excelentes características impermeáveis e de adesividade, sendo altamente resistente à ação da maioria dos ácidos, álcalis e sais. O maior uso dos cimentos asfálticos é nas misturas asfálticas para pavimentação (ROBERTS et al. 1991).

Leite (1999), relata que Samanos definiu o cimento asfáltico de petróleo como um adesivo termoplástico, impermeável à água, viscoelástico e pouco reativo, que: 
- pelo comportamento termoplástico, possibilita o próprio manuseio a quente, para aplicação em pavimentos e, por simples resfriamento, o retorno às suas propriedades viscoelásticas correspondentes às condições de serviço;

- sendo utilizado na impermeabilização da estrutura do pavimento, evita a penetração da água de chuva, acarretando escoamento superficial para os canais de drenagem;

- tem na viscoelasticidade a base do comportamento mecânico que exerce sobre a estrutura do pavimento. Como essa propriedade indica, o CAP combina dois comportamentos distintos: o elástico, sob aplicação de carga de curta duração (tráfego rápido), e o viscoso, sob longos períodos de aplicação de carga;

- tem boa durabilidade, em face da pouca reatividade química. O contato com o ar propicia oxidação lenta, que pode ser acelerada pelo aumento da temperatura.

\subsubsection{Constituição química do asfalto}

Existe uma grande dificuldade em definir a composição química dos asfaltos devido à dificuldade de caracterização de todas as substancias que o compõem, algumas ainda desconhecidas.

A proporção aproximada de seus principais componentes, de acordo à origem dos cru da qual provêem o asfalto são:

- Carbono(82 a 87\%)

- Hidrogênio (9 a 11\%)

- Nitrogênio $(0,2$ a $1,2 \%)$

- Enxofre (0,9 a 5,3\%) 
- Oxigênio $(0,2$ a $0,8 \%)$

- Vanádio (4 a 1400 ppm)

- Níquel (0,4 a 110 ppm).

O fracionamento químico separa o CAP em compostos saturados, nafteno-aromáticos, polararomáticos e asfaltenos (insolúveis em n-heptano). Os asfaltenos separam-se primeiro, por precipitação, com a adição de n-heptano. Os outros constituintes, denominados maltenos, solúveis em n-heptano, são separados por cromatografia de adsorção. Os asfaltenos são aglomerados de compostos polares e polarizáveis, formados em conseqüência de associações intermoleculares. São considerados responsáveis pelo comportamento reológico dos CAP e constituídos de hidrocarbonetos naftênicos condensados e de cadeias curtas de saturados (LEITE e BITTENCOURT, 2004).

\subsubsection{Relação entre composição química e propriedades físicas do asfálto}

Segundo Corbett ${ }^{1}$ (1978 apud LEITE, 1999), os componentes do CAP têm as seguintes propriedades:

- Saturados: Têm influência negativa na suscetibilidade térmica. Em maior concentração amolecem o produto;

- Aromáticos: Agem como plastificantes, contribuindo para a melhoria de suas propriedades físicas;

\footnotetext{
${ }^{1}$ CORBETT, L. W. \& PETROSSI, U. (1978)- Differences in distillation and solvent asphalt - Industrial
} Engineers Chemical Production, Research \& Development, vol 17, p. 342 
- Resinas: Têm influência negativa na suscetibilidade térmica, mas contribuem na melhoria da ductilidade e dispersão dos asfaltenos;

- Asfaltenos: Contribuem para a melhoria da suscetibilidade térmica e aumento da viscosidade.

Embora a composição química e a estrutura coloidal sejam somente auxiliares na explicação de alguns fenômenos do comportamento do CAP como ligante asfáltico, os parâmetros reológicos de CAP obtidos através de viscosímetros e reômetros de cisalhamento dinâmico apresentam correlação com ensaios de desempenho de misturas betuminosas (LEITE, 1999).

\subsubsection{Envelhecimento}

O envelhecimento do ligante asfáltico pode ser definido como o processo que sofre o cimento asfáltico durante a estocagem, usinagem, aplicação e vida em serviço, responsável pela alteração de suas características físicas, químicas e reológicas que causam um aumento na sua consistência.

Segundo Leite (1999), quatro são os mecanismos principais que explicam o endurecimento ou envelhecimento do asfalto, a saber: oxidação, perda de voláteis, endurecimento físico e endurecimento exsudativo.

A oxidação é a mais importante causa do endurecimento. Durante a usinagem, a alta temperatura empregada e a presença do ar tornam a oxidação violenta. Os grupos polares oxigenados tendem a associar-se, formando micelas de alto peso molecular e maior 
viscosidade. Embora a estocagem do CAP se faça também a altas temperaturas, a oxidação do CAP em tanques é minimizada pela pequena superfície exposta ao ar

O endurecimento resultante da perda de voláteis é baixo, tendo em vista que os cimentos asfálticos de petróleo não são voláteis;

O endurecimento físico ocorre à temperatura ambiente e é atribuído à reordenação de moléculas e à cristalização de parafinas. É um fenômeno reversível;

O endurecimento exsudativo resulta de movimento de componentes oleosos do ligante para o agregado mineral.

A primeira alteração da estrutura química do CAP após sua produção ocorre durante a usinagem, espalhamento e compactação da mistura betuminosa e depois ocorre uma evolução mais lenta, durante a vida em serviço.

Segundo Bicheron et al. ${ }^{2}$ (1986 apud LEITE, 1999), o processo de oxidação é descrito pelas seguintes modificações na composição química do CAP:

- inércia química dos saturados, cujo teor se mantém praticamente inalterado;

- oxidação parcial dos aromáticos que se transformam em resinas;

- oxidação das frações mais pesadas das resinas que se transformam em asfaltenos;

- uma parte dos próprios asfaltenos se oxida, modificando seu comportamento.

${ }^{2}$ BICHERON G., BRULÉ B., MIGLIORI F (1986) - Régéneration des liants pour enrobés: méthodologie d'étude en laboratoire. Exemple de quelques cas de chantiers. Bull. Liaison Labo. P. Ch., vol 143, p104-110, mai/juin 1986 


\subsubsection{Asfalto Modificado por Polímero}

Os ligantes asfálticos têm uma grande importância em muitos aspectos do desempenho de uma rodovia, suportando os carregamentos do tráfego sob diferentes condições climáticas. Assim, uma mistura asfáltica necessita ser flexível em temperaturas de serviço baixas, para prevenir as trincas térmicas no pavimento, e suficientemente rígida a temperaturas altas de serviço, para prevenir as deformações permanentes. Nem sempre as misturas asfálticas produzidas com asfalto convencional apresentam as propriedades desejáveis, havendo uma busca constante de novos materiais, que melhorem o desempenho dos pavimentos asfálticos, como, por exemplo, os asfaltos modificados por polímeros.

Os asfaltos modificados por polímero são obtidos a partir da incorporação de polímero ao CAP, em unidade apropriada, podendo ou não envolver reação química. Os ligantes asfálticos que se prestam à modificação são aqueles que apresentam compatibilidade com o polímero a ser empregado. Um bom asfalto modificado deve apresentar o polímero e o asfalto “entrelaçados", formando duas fases contínuas, uma permeando a outra. Caso a mistura não seja realizada de forma adequada, ou o polímero e o asfalto não sejam quimicamente compatíveis, formam-se duas fases com predominância de uma ou de outra. Em ambos os casos, as propriedades do asfalto modificado não serão adequadas para utilização.

Segundo Leite e Soares (1997), a modificação de ligantes asfálticos pela introdução de polímeros é empregada há mais de trinta anos em países desenvolvidos, visando melhorar a resistência à fadiga e à deformação permanente dos pavimentos. Porém a utilização deste tipo de produto não chega a quinze por cento do mercado Americano e Europeu de ligantes asfálticos devido ao preço elevado. Seu uso se destina a novos tipos de aplicações, tais como, 
asfaltos drenantes, concretos asfálticos de alto módulo, micro revestimento, membranas antifissuras etc.

Porém, segundo Yildirim (2005), a modificação dos asfaltos com polímero se incrementou nas ultimas três décadas, tornando-se norma nos projetos de pavimentos de alto desempenho, particularmente nos Estados Unidos, Canadá, Europa e Austrália.

\subsubsection{Polímeros}

Os polímeros são substâncias macromoleculares, ou seja, que contêm centenas ou milhares de átomos, que podem ser extraídas da natureza (madeira, óleo lubrificante, cortiça etc.) ou podem ser obtidas artificialmente, pela união em rede ou estrutura de rede de pequenas moléculas, chamadas de monômeros.

A classificação dos polímeros pode ser feita em quatro categorias: plásticos, elastômeros, fibras e aditivos. Os plásticos são subdivididos em termoplásticos e termorrígidos, enquanto os elastômeros subdividem-se em borracha natural e sintética (ISACSSON \& LU, 1995).

Termoplásticos: são aqueles que depois de formados pela ação do calor, amolecem de forma reversível, sendo possível moldá-los novamente. Em outras palavras, amolecem quando aquecidos e endurecem quando resfriados. Por exemplo: etileno-acetato de vinila (EVA), polietileno, polipropileno atático, policloreto de vinila;

Termorrígidos: são aqueles que, depois de formados pela ação do calor, endurecem, conferindo à sua estrutura espacial um caráter de rigidez irreversível. Ao serem aquecidos 
novamente, não amolecem mais, impossibilitando sua remodelagem. Por exemplo: resina epóxica, poliuretano;

Elastômeros: são aqueles que, quando aquecidos, se decompõem antes de amolecer. Apresentam propriedades elásticas que lembram ao da borracha. Por exemplo: Styrene Butadiene Rubber (SBR);

Elastômero-Termoplásticos: são aqueles que, em altas temperaturas, se comportam como termoplásticos, ou seja, amolecem quando aquecidos e endurecem quando resfriados, mas em menores temperaturas apresentam propriedades elásticas. Por exemplo: SBS.

\subsubsection{Propriedades Modificadoras dos Polímeros}

As características físicas e mecânicas dos asfaltos modificados por polímero dependem do tipo de polímero, do tipo do asfalto, do teor de polímero e do processo de fabricação utilizado. A complexa relação entre a composição química dos asfaltos, sua estrutura coloidal e suas propriedades físicas e reológicas indicam que qualquer elemento que modifique sua composição química certamente modificará sua estrutura e, conseqüentemente, suas propriedades (BRÛLÉ, 1996).

Segundo Pinto (1993) e Isacsson \& Lu (1995), os polímeros, quando adicionados ao cimento asfáltico, melhoram certas características das misturas asfálticas, como a suscetibilidade térmica, a coesão, a elasticidade e a resistência à fadiga, da seguinte forma: 
- a susceptibilidade térmica caracteriza a variação da consistência em função da temperatura, dessa forma a modificação de um asfalto através da adição de polímero tem por objetivo aumentar a faixa de temperatura de serviço, limitando o enrijecimento ou amolecimento devidos às variações de temperatura;

- a coesão pode ser definida como sendo a energia necessária para romper um filme de ligante, variando em função da temperatura. Sendo assim, o objetivo da modificação de asfalto por polímero é aumentar a coesão máxima e/ou a faixa de coesão, obtendo uma consistência satisfatória em toda a faixa de temperatura de serviço;

- a elasticidade é a propriedade que os materiais, apresentam de suportar as ações do tráfego e das variações de temperatura, de modo cíclico, sem o acúmulo de deformações. A modificação de asfalto por polímero acentua e/ou mantêm o comportamento elástico do material, em uma faixa mais ampla de temperatura de utilização;

- a resistência à fadiga refere-se à capacidade inerente aos materiais de resistirem às repetidas solicitações aplicadas pelo tráfego, sem romper, sendo que a modificação de asfalto por polímero aumenta essa resistência, principalmente sob baixas temperaturas.

Essas características incorporadas implicam, diretamente, em benefícios às misturas asfálticas, através da redução da susceptibilidade térmica, do aumento da flexibilidade e elasticidade sob baixas temperaturas, da melhoria da resistência às trincas e às deformações permanentes sob altas temperaturas, do aumento da resistência à tração e à fadiga, do aumento das forças de adesão e coesão do conjunto agregado/ligante e da maior resistência ao desgaste e ao envelhecimento da mistura. 


\subsubsection{Polímero SBS (estireno-butadieno-estireno)}

SBS é um copolímero elastomérico termoplástico com cadeias intermediárias de polibutadieno e cadeias terminais de poliestireno, constituindo assim blocos de polímeros incompatíveis (poliestireno termoplástico e polibutadieno elastomérico). O sistema SBS tem duas fases a temperatura ambiente (polibutadieno que apresenta temperatura de transição vítrea de $-90^{\circ} \mathrm{C}$ e o poliestireno de $100^{\circ} \mathrm{C}$ ). À medida que a temperatura se eleva, os domínios se dispersam, os blocos terminais não se fixam mais ao domínio e o SBS se comporta como corpo plástico. $\mathrm{O}$ fenômeno de comportamento plástico a alta temperatura e elástico a baixa temperatura é totalmente reversível (LEITE e SOARES, 1997).

Segundo Ceratti et al. (1996), o polímero SBS apresenta forte interação com a base betuminosa por ser compatível com seus componentes aromáticos e não aromáticos. Quando o polímero é disperso no asfalto quente, os domínios de poliestireno dissolvem-se, assumindo características termoplásticas, que facilitam as operações de mistura e compactação. Sob resfriamento, os blocos de poliestireno reassociam-se, formando uma rede tridimensional dispersa numa matriz de polibutadieno, conferindo propriedades de resistência e elasticidade à mistura.

Segundo Ramos et al. (1996), o polímero SBS, por ser termoplástico, permite que o cimento asfáltico a altas temperaturas possa fluir, devido à fusão dos domínios de estireno, e a baixas temperaturas impede que o cimento asfáltico se torne quebradiço, devido à presença dos domínios de butadienos. Nas temperaturas mais altas de trabalho do pavimento, o cimento asfáltico torna-se excessivamente fluido, sendo que os domínios de estireno permanecem, ainda, sólidos. Como o cimento asfaltico fica envolvido pela malha de SBS, o novo ligante 
trabalha, nessas condições, como borracha vulcanizada, tornando-se fluido em temperaturas mais elevadas do que as atingidas pelo pavimento.

Segundo Leal (1999), com a elevação do ponto de amolecimento e, ao mesmo tempo, com a diminuição do ponto de ruptura Fraass do CAP, a presença do elastômero termoplástico SBS no CAP aumenta bastante o seu intervalo de plasticidade (Ponto de Amolecimento subtraído o Ponto de Ruptura Fraass), o que significa uma considerável melhoria da sua susceptibilidade térmica, que mede a influência das variações de temperatura na resistência do asfalto, que é a qualidade mais procurada em aditivos para o CAP.

Em estudos feitos com asfaltos modificados por polímero SBS, observaram que o polímero SBS fez aumentar a elasticidade dos asfaltos em altas temperaturas e aprimorou a flexibilidade dos mesmos a baixas temperaturas, ou seja, contribuem para um aumento na resistência às deformações permanentes nas trilhas de roda e às trincas, nas altas e baixas temperaturas, respectivamente (LU \& ISACSSON, 1997).

Segundo Becker et al. (2001), provavelmente o SBS é o polímero mais apropriado para a modificação do asfalto, embora a adição de SBS tipo copolímero em bloco tenha limitações econômicas. De qualquer forma, o SBS é o polímero mais usado para modificar asfaltos, seguido por borracha de pneu reciclada.

\subsubsection{Vantagens técnicas dos asfaltos modificados por polímeros}

Segundo Reis (2002), as vantagens técnicas dos asfaltos modificados por polímeros, são: 
- diminuição da suscetibilidade térmica (a consistência do asfalto modificado permanece inalterada sob larga faixa de temperaturas. Em clima frio, seu caráter flexível aumenta a resistência às trincas e fissuras na superfície do revestimento. Em clima quente, o incremento do ponto de amolecimento e da viscosidade do ligante reduz o risco de exsudação, afundamentos em trilhas de roda e perda da macrotextura do revestimento);

- melhor característica adesiva e coesiva (aumenta a resistência à desagregação do pavimento. A resistência coesiva faz com que o ligante asfáltico mantenha os agregados unidos, quando sujeitos à ação das cargas de tráfego, em especial nas baixas temperaturas);

- maior resistência ao envelhecimento (aumenta a vida útil do ligante);

- elevação do Ponto de Amolecimento - PA (diminui a deformação permanente);

- diminuição do Ponto de Ruptura Fraass - PF, temperatura em que o asfalto sofre trincas quando submetido à tensão (diminui as trincas térmicas);

- aumento do intervalo de plasticidade, faixa de temperatura na qual o asfalto pode ser utilizado (conseqüência do Ponto de Amolecimento elevado e Ponto de Ruptura Fraass baixo);

- maior resistência à deformação permanente (aumento da elasticidade);

- excelente comportamento reológico (a resistência à fluência e/ou boa recuperação elástica do ligante modificado, sob tensões de tração, mantém a integridade do revestimento, mesmo quando sujeito a níveis elevados de carga e deslocamento).

\subsubsection{Processo de incorporação e mecanismo de modificação do asfalto com polímero SBS}

O processo de incorporação de SBS no asfalto requer que o CAP utilizado como matéria prima tenha uma relação asfaltemos/aromáticos dentro de uma determinada faixa, visualizada 
na Figura 2.2, de modo a assegurar compatibilidade ou estabilidade à estocagem do produto final (WHITEOAK, $1990^{3}$ apud Leite e Soares, 1997).

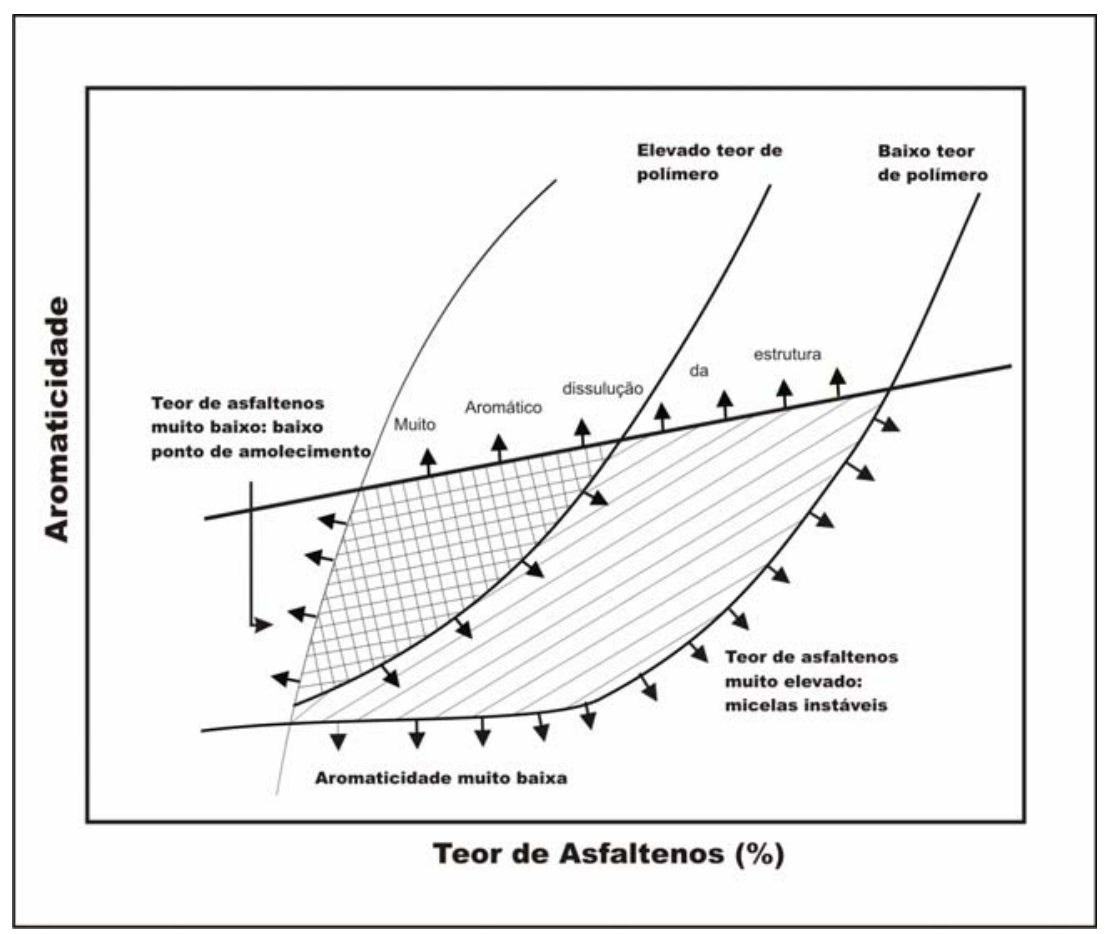

Figura 2.2 - Influência da composição química do CAP na compatibilidade de asfaltos modificados por SBS.

Fonte: WHITEOAK (1990 apud Leite e Soares)

A adição de compatibilizantes à mistura de CAP e SBS altera a relação asfaltenos/aromáticos e a viscosidade da mistura, tornando a mistura compatível e com consistência adequada para conferir à mistura final propriedades reológicas muito superiores às do CAP. Esses compatibilizantes são diluentes aromáticos oriundos de unidades de produção de lubrificantes, unidades de craqueamento catalítico ou de unidades de destilação á vácuo de óleo de xisto.

As condições de operação de preparo dependem da granulometria do SBS, do teor de SBS, do tempo de residência, de velocidade de agitação e da temperatura. Emprega-se, 
preferencialmente, agitação com alto cisalhamento, SBS em grãos, atmosfera inerte, temperatura e tempo suficiente para conferir incorporação do polímero, resistência ao envelhecimento, melhoria de propriedades reológicas e compatibilidade. (BOULDIN \& COLLINS, 1990).

A adição de polímero ao CAP não melhora suas propriedades reológicas linearmente. A alteração do ponto de amolecimento do asfalto modificado com o teor de polímero pode ser visualizada na Figura 2.3, apresentada por Leite e Soares (1997). Existe uma zona de 4 a 7 \% de SBS que corresponde à mudança de microestrutura, da fase cuja matriz é o CAP $(<4 \%)$. para a fase cuja matriz é o SBS (>7\%). A mudança de microestrutura é a responsável pelas alterações reológicas não lineares introduzidas por adição crescente de SBS.

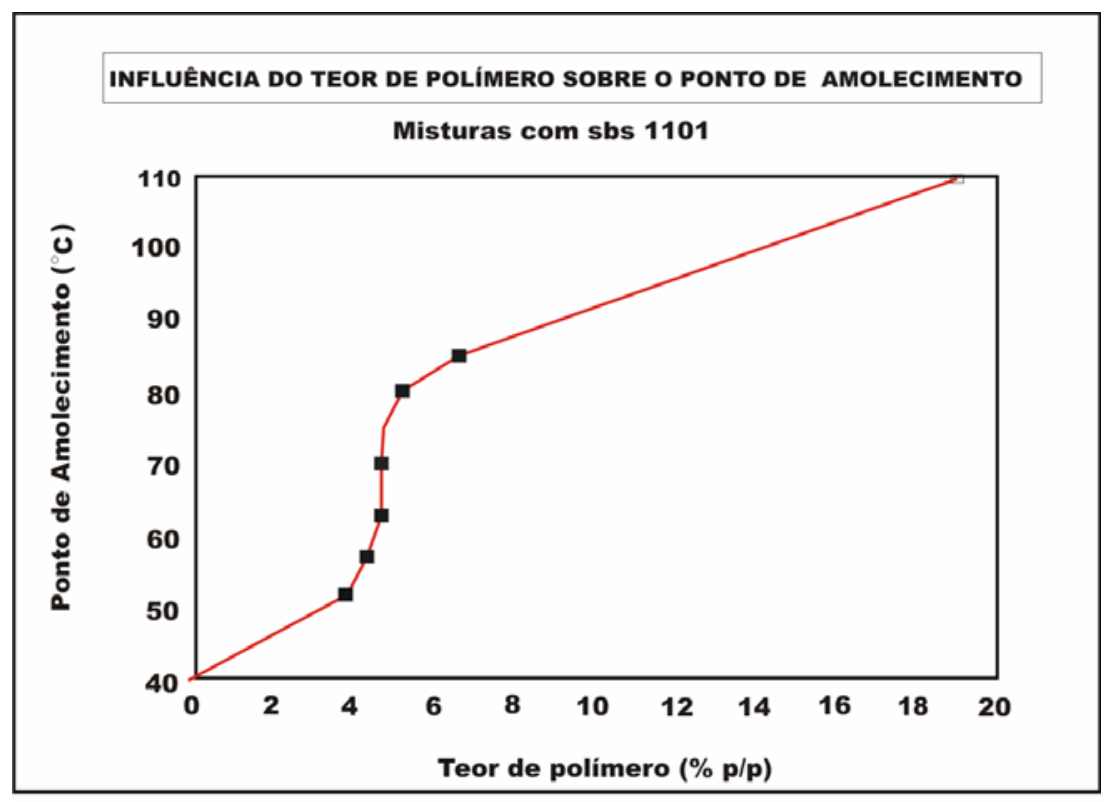

Figura 2.3 - Alteração do ponto de amolecimento do asfalto modificado com o teor de polímero.

Fonte: Leite e Soares 1997 
A modificação das propriedades do asfalto pela adição do polímero é explicada pelo inchamento do polímero nos maltenos do CAP. Têm-se duas fases dentro do asfalto modificado na escala micro:

- fase rica em polímero, que contém polímero e parte dos maltenos adsorvidos pelo polímero.

- fase rica em asfaltenos, que consiste de todos os componentes do CAP, particularmente os asfaltenos, que não são adsorvidos pelo polímero.

O inchamento acarreta aumento de viscosidade e desenvolve caráter gel no ligante, tornando-o mais elástico e resistente ao estiramento. A taxa de inchamento é dependente do modo de preparo da mistura. O aumento da temperatura aumenta a polidispersão, mas pode degradar o polímero. Os agitadores munidos de rotor/estator resultam em misturadores melhores que os de hélice.

Com relação aos volumes das duas fases, pode-se afirmar que o SBS e copolímeros de etileno podem adsorver até nove vezes do seu próprio peso em componentes do CAP, significando extensão de volume de 900\%, mas a capacidade de adsorção reduz com aumento da concentração de polímero.

Leite (1999), apresenta a observação da estrutura de uma série de asfaltos modificados com SBS e copolímeros de etileno, com teor crescente de polímero, no microscópio de reflexão de fluorescência, que revelou os seguintes fatos, conforme ilustra a Figura 2.4.: 
- baixos teores de polímero (abaixo de 5\%): apresentam fase asfáltica contínua, com polímero disperso. Nessa situação, as propriedades da mistura são modificadas principalmente pelo aumento do teor de asfaltenos na fase asfáltica. A escolha do CAP é, portanto determinante nas propriedades da mistura. (Figura 2.4. $-\mathrm{A}$ ).

- altos teores de polímero (acima de 5\%): apresentam fase polimérica contínua, com a fase rica em asfaltenos dispersa. (Figura 2.4. $-\mathrm{B}$ ).

- teores de polímero em torno de 5\%: observam-se duas fases contínuas entrelaçadas (Figura 2.4.-C) (WORLD ROAD ASSOCIATION, $1998^{4}$ apud Leite, 1999).

A

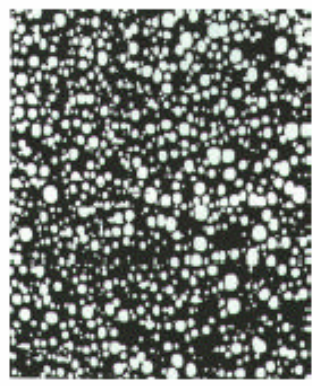

B

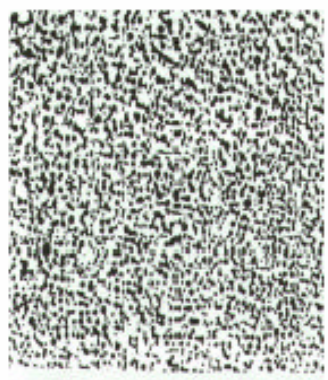

$\mathrm{C}$

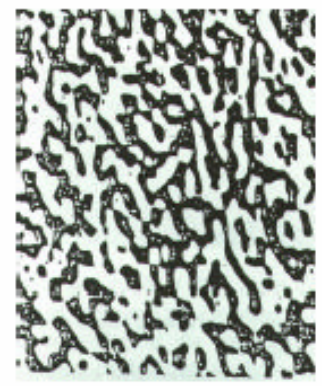

Figura 2.4 - Observação de estruturas de asfalto modificado com diferentes teores de SBS no microscópio de reflexão de fluorescência.

Fonte: WORLD ROAD ASSOCIATION ${ }^{4}$ (1998 apud Leite, 1999)

\subsubsection{Produção do asfalto modificado por polímero}

A incorporação do polímero no asfalto pode ser feita de três maneiras:

a) Produção do asfalto modificado numa fábrica, em local separado, e transporte do produto final para usina de asfalto;

\footnotetext{
${ }^{4}$ WORLD ROAD ASSOCIATION - TECHNICAL COMMITTEE FLEXIBLE ROADS (June 1998) - Use of modified bituminous binders, special bitumens with additives in pavement applications International Workshop Modified Bitumens Roma, 17-19.
} 
b) Preparo do asfalto modificado num misturador auxiliar na usina de asfalto;

c) Incorporação do polímero diretamente na mistura asfáltica, durante o processo de mistura de asfalto com agregados.

A escolha da tecnologia depende das condições locais e do tipo do polímero. Polímeros difíceis de compatibilizar e instáveis termicamente devem ser misturados imediatamente antes do uso do asfalto modificado, de modo a evitar decomposição e/ou separação de fases. Produção em fábrica, separada do local da usinagem significa melhor controle de qualidade e melhor dispersão do polímero no asfalto. A alternativa (b) garante melhor incorporação do polímero no CAP do que a alternativa (c). A Figura 2.5. resume as várias alternativas de produção de asfalto modificado por polímero.

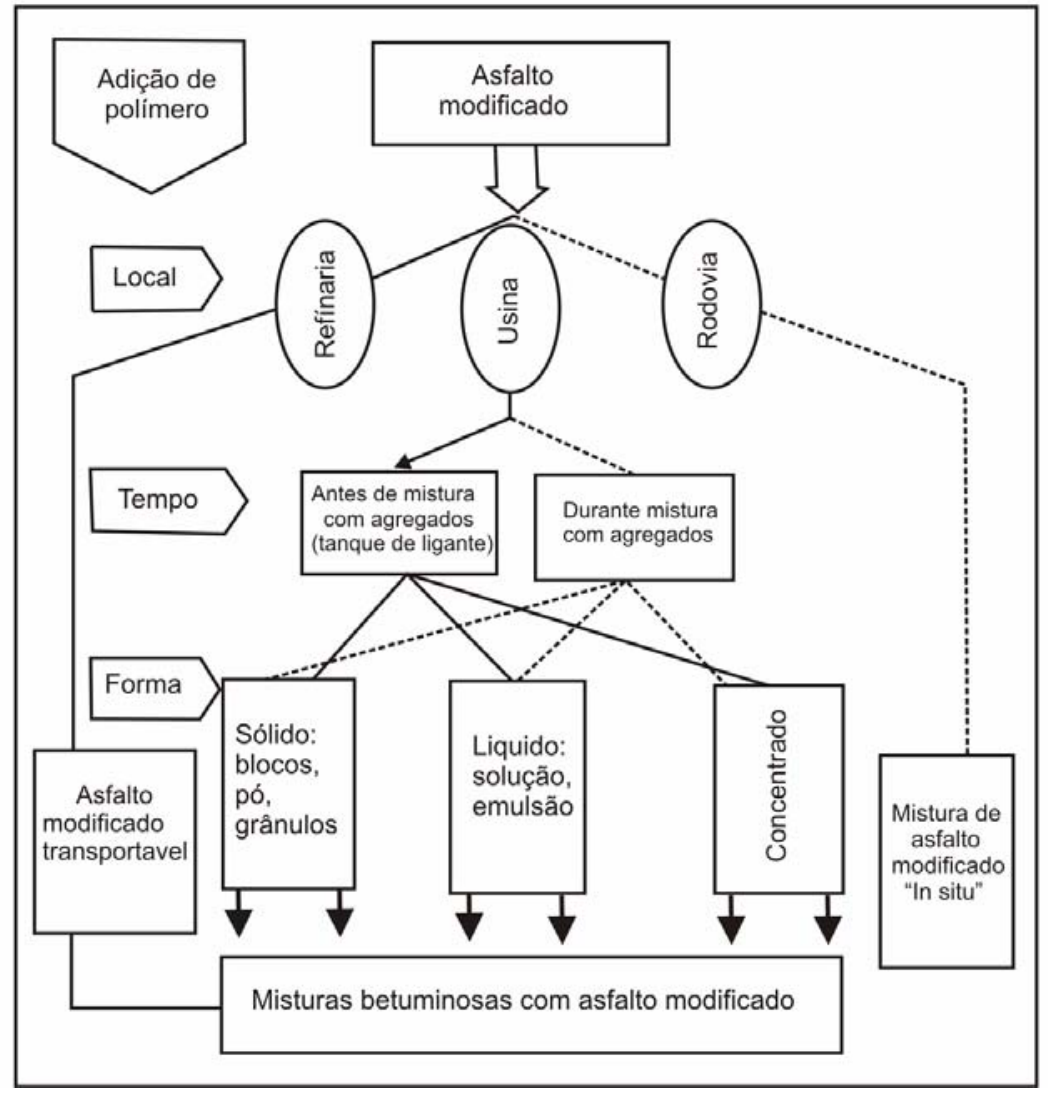

Figura 2.5 - Alternativas para produção de asfalto modificado por polímero.

Fonte: MANO (1985) 
Para que haja uma mistura íntima entre o asfalto e o polímero, além de uma boa afinidade estrutural, é também necessária uma agitação eficiente, que propicie a formação de uma fase contínua constituída pelo polímero, em que o asfalto esteja finamente disperso.

No processo de preparação podem ser utilizados desde misturadores antigos verticais de baixa velocidade até modernos misturadores de alta velocidade. O tempo de mistura pode variar de uma a doze horas, ou mais, dependendo do equipamento. Misturadores de alta velocidade é a escolha mais eficiente do ponto de vista de qualidade de produto e organização da fábrica.

A Figura 2.6 mostra um diagrama simplificado para produção de asfaltos modificados com elastômeros termoplásticos estirênicos. O polímero pode ser adicionado em pó ou grânulos, ou ainda em forma de látex (SBR). O CAP quente e o polímero são pesados e colocados num pré-misturador de baixa velocidade para que o CAP umidifique o polímero. A duração e a temperatura desta fase são ajustadas para assegurar inchamento do polímero. A mistura é então transferida para misturador de alta velocidade, onde o sistema asfalto-polímero alcança adequada dispersão e homogeneidade. Finalmente, o asfalto modificado é transferido para o tanque. Se a dispersão da mistura final se apresentar inadequada, o sistema de válvulas será usado para retorno da mistura ao agitador de alta velocidade. 


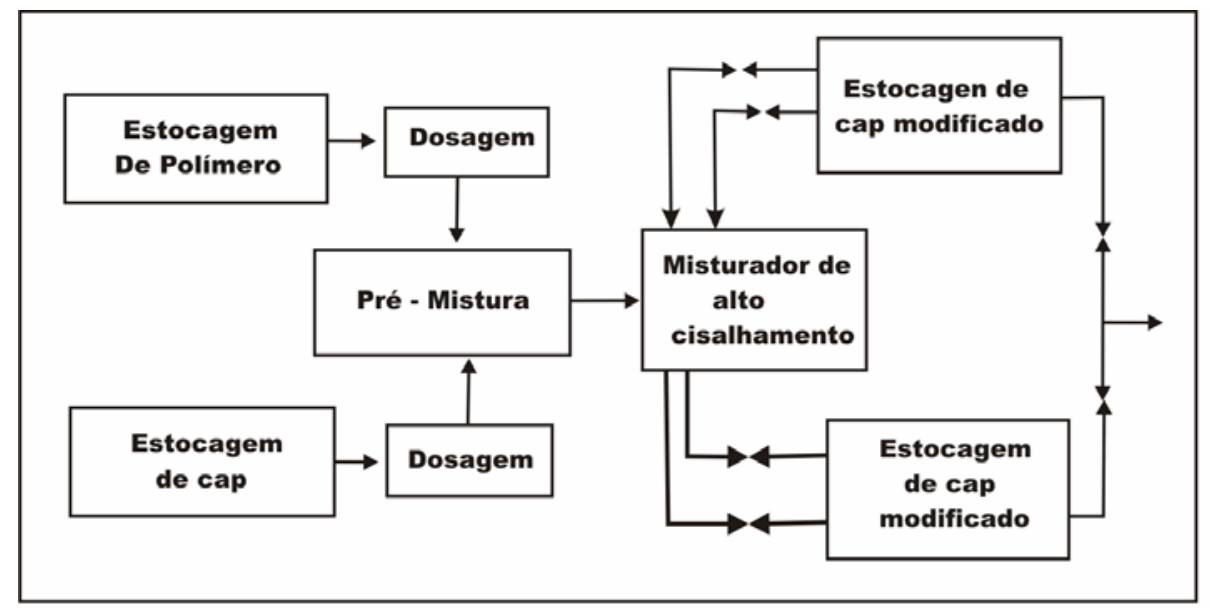

Figura 2.6 - Diagrama de produção de asfaltos modificados com elastômeros termoplásticos estirênicos.

Fonte: WORLD ROAD ASSOCIATION ${ }^{4}$ (1998 apud Leite, 1999)

Os parâmetros de mistura (velocidade de agitação e taxa de cisalhamento) e temperatura (entre 180 e $200^{\circ} \mathrm{C}$ ) devem ser cuidadosamente controlados, de modo a conseguir boa dispersão num tempo mínimo de mistura. Quando a temperatura é muito baixa, a dispersão se torna difícil, enquanto temperaturas acima de $200^{\circ} \mathrm{C}$ podem iniciar oxidação do CAP ou do polímero.

O ligante resultante pode ser tanto o produto final ou um concentrado que será diluído para o desejado teor de polímero num estágio posterior. A operação de diluição pode ser conduzida em batelada ou continuamente com misturadores estacionários e bombas (LEITE, 1999).

\subsubsection{Histórico do uso do asfalto modificado com polímero}

A primeira rodovia construída com asfalto modificado que se tem conhecimento foi feita em 1902, em Cannes, na França, sendo que muitos asfaltos modificados foram usados antes da Segunda Guerra Mundial, todos feitos com borracha natural, único material devidamente 
avaliado até então. Devido ao desempenho positivo das experiências iniciais, começaram a ser avaliados novos materiais com potencial para serem modificadores de asfalto.

Após a Segunda Guerra Mundial, o polímero sintético começou a tomar lugar da borracha natural e ser utilizado como aditivo modificador de asfalto. Atualmente, pode-se perceber o grande interesse em polímeros sintéticos devido ao grande número de artigos relacionados a esse respeito.

Em 1963, na França, foi construída uma pista de testes para a determinação do comportamento de misturas asfálticas produzidas com asfalto modificado com vários tipos de borrachas naturais e sintéticas, porém os resultados não foram satisfatórios, evidenciando a necessidade de novas pesquisas. Porém, apenas em 1972 o governo francês incentivou pesquisas para o desenvolvimento de asfaltos modificados com polímeros termoplásticos (BRÛLÉ, 1996). A França, na época, aplicava anualmente cerca de 200.000 toneladas de asfalto modificado por polímero, o que representava $8 \%$ do consumo total de CAP em pavimentação (RAMOS et al.,1996).

Os altos custos iniciais dos asfaltos modificados com polímero limitaram seu uso nos Estados Unidos. Porém, nos anos de 1980, novos polímeros foram desenvolvidos e tecnologias européias começaram a ser usados nos Estados Unidos, ao mesmo tempo que começou a prevalecer a perspectiva econômica a longo prazo. Na Austrália, por exemplo foram desenvolvidas especificações e manuais incluindo asfaltos modificados por polímeros.

Segundo Bahia et al. (1997), pesquisas do departamento de transportes dos Estados Unidos encontraram que 47 estados dos 50 reportados usariam asfalto modificado no futuro, sendo 
que 35 disseram que poderiam usar grandes quantidades. Muitas equipes de pesquisa em todo o mundo vêm trabalhando a respeito da avaliação dos benefícios do polímero modificador no desempenho do pavimento, e ensaios e especificações para ligantes vêm sendo continuamente desenvolvidas.

Em 2001 numa pesquisa para o Departamento de Transporte de Ohio, Sargand e Kim compararam a resistência à fadiga e deformação permanente de três ligantes asfálticos PG 70 -22, um não modificado, um modificado com SBS e outro modificado com SBR. Os ligantes modificados mostraram-se mais resistentes à fadiga e deformação permanente que o ligante não modificado, embora todos os três tivessem o mesmo grau de desempenho.

Em 2003, o Corpo de Engenheiros do Exército dos Estados Unidos realizou uma pesquisa que concluiu que a escolha de polímeros pode ter um impacto significativo em propriedades de fadiga e que as misturas que ostentam a vida de fadiga mais alta contêm reativos entrelaçados de polímero estireno - butadieno, tendo sido testados borracha moída, borracha de estireno butadieno (SBR), blocos lineares de SBS e um modificado patenteado SBS.

\subsubsection{Histórico no Brasil sobre o estudo e aplicação do asfalto modificado com polímero na pavimentação}

No Brasil, o Instituto de Pesquisa Rodoviária do Departamento Nacional de Estradas de Rodagem (IPR/DNER), impulsionou o uso de asfaltos modificados por polímeros quando, em 1988, iniciou pesquisas nessa área. Em 1990 foi realizada a primeira experiência de campo, na rua Leopoldo Bulhões, na cidade do Rio de Janeiro. A rua apresentava severas deflexões e muitas trincas. Após quatro anos de uso, desde a intervenção, a seção da via, que fora 
recuperada com asfalto modificado, apresentava excelentes condições, enquanto a seção onde fora utilizado asfalto convencional apresentava excessivo trincamento (MARTINHO et al., 1994 e RAMOS et al., 1996).

A maior obra realizada no Brasil com o uso de asfalto-polímero foi no Autódromo Internacional "Nelson Piquet", na cidade de Rio de Janeiro, em 1995, onde foram utilizadas novecentos e setenta e quatro toneladas de ligante modificado com polímero SBS. O desempenho foi considerado bom, principalmente quanto à adesão e coesão proporcionadas pelo ligante modificado (RAMOS et al., 1996).

\subsubsection{Cimentos asfálticos de petróleo, Especificação Brasileira}

As especificações brasileiras foram mudando com o decorrer dos anos. A primeira especificação brasileira foi de 1957 - ABNT EB-78, baseada na ASTM D 948-47T ou ASHTO M2042. Classificava os cimentos asfálticos por penetração, a $25^{\circ} \mathrm{C}$, sem intervalos entre as classes, num total de 10 classes. $30-40 ; 40-50 ; 50-60 ; 60-70 ; 70-85 ; 85-100 ; 100-120$; $120-150 ; 150-200 ; 200-300$.

A segunda especificação brasileira, aprovada por resolução do Conselho Nacional do Petroleo (CNP) de 1969 e publicada em 1970, reduz a ABNT EB-78 para apenas quatro tipos de CAP: 30-45; 50-60; 85-100; 150-200. Em outubro de 1984, na 184a Reunião da Comissão de Asfalto (CA) do Instituto Brasileiro de Petróleo (IBP), foi decidida a criação de duas especificações por viscosidade a $60^{\circ} \mathrm{C}$, com três tipos de CAP: 7, 20 e 55, sem "gap", e por penetração a $25^{\circ} \mathrm{C}$, com três tipos de CAP 30-45; 50-60; 85-100. Foi assim que se 
implementou as especificações por penetração e viscosidade em 1992, de acordo com o regulamento técnico 01/92- Rev .02-DNC.

Em outubro de 2004, a comissão do asfalto do IBP aprovou a nova proposta para as especificações de CAP, baseada nos relatórios da Associação Brasileira de concessionárias rodoviárias (ABCR) e da Petrobras, ambas baseadas em penetração, com quatro tipos de CAP $30-45 ; 50-70 ; 85-100 ; 150-200$. Assim atualmente os órgãos oficiais brasileiros classificam o CAP quanto a sua consistência por penetração a $25^{\circ} \mathrm{C}$ (ABNT NBR-6576/2005).

\subsubsection{Cimentos asfálticos de petróleo, Especificação Americana (Superpave)}

Uma parte importante do Superpave é a nova especificação para os ligantes asfálticos que está associada a um novo sistema de ensaios. As especificações para os asfaltos estão estabelecidas na AASHTO MP1 "Standard Specification for Performance Graded Asphalt Binder". A especificação Superpave de ligante asfáltico baseia-se no desempenho do material, considerando o clima e temperatura do pavimento onde se pretende usar o ligante. Os requisitos quanto as propriedades físicas permanecem os mesmos, porém muda a temperatura em que o ligante deve atendê-las. Por exemplo, a altas temperaturas a rigidez de um ligante não envelhecido $\left(\mathrm{G}^{*} / \mathrm{sen} \delta\right)$ deve ser no mínimo $1,0 \mathrm{kPa}$. Este requisito deve ser obtido a temperaturas mais elevadas, caso se deseje usar este ligante em um clima mais quente que outro (MOTTA et al., 1996).

O grau de desempenho (Performance Grade - PG) de um ligante asfáltico, é composto por dois números, (por exemplo PG 64 -22) em que o primeiro número indica a máxima temperatura na qual o ligante asfáltico mantém suas propriedades durante a vida de serviço 
em um pavimento $\left(64^{\circ} \mathrm{C}\right)$, enquanto o segundo número indica a mínima temperatura na qual o ligante asfáltico possui adequadas propriedades físicas durante sua vida de serviço, $\left(-22^{\circ} \mathrm{C}\right)$. Considerações adicionais são proporcionadas em termos de volume de tráfego e tempo de aplicação de carga.

Outro ponto fundamental na avaliação do sistema Superpave é que as propriedades físicas também são medidas em ligantes que sofreram envelhecimento no laboratório, de forma a simular o que ocorre no pavimento real. Algumas propriedades físicas são determinadas no ligante não-envelhecido, outras propriedades físicas são medidas em ligantes que sofreram envelhecimento em estufa de filme fino rotativo (RTFOT), que simula o envelhecimento do ligante que acontece durante a usinagem e compactação da mistura, e no vaso de envelhecimento sob pressão (PAV), que simula o envelhecimento oxidativo que acontece no ligante, ao longo da vida útil do pavimento (MOTTA et al., 1996).

\section{Principio de caracterização dos Asfaltos pelas Especificações Superpave}

As especificações Superpave procuram simular, por meio de ensaios de laboratório, os três estados críticos aos quais se expõe o asfalto durante a vida de serviço:

- Primeiro estado: asfalto original, durante o transporte, armazenagem e manipulação do ligante asfáltico;

- Segundo estado: envelhecimento produzido depois da fabricação e colocação da mistura asfáltica;

- Terceiro estado: envelhecimento da mistura asfáltica durante a vida em serviço. 
As propriedades físicas dos asfaltos no método Superpave também são medidas sobre os asfaltos envelhecidos no laboratório, simulando assim as condições reais de operação do pavimento. A medida das propriedades físicas se realiza mediante a utilização de seis equipamentos de ensaio, cujos objetivos são detalhados na Tabela 2.5.

Tabela 2.5 - Aparelhos de ensaio do método Superpave.

\begin{tabular}{cc}
\hline Equipamento & Objetivo \\
Pressure Aging Vessel (PAV) & Simula características de envelhecimento do \\
\hline asfalto, respectivamente no curto e longo prazo. \\
Dynamic Shear Rheometer (DSR) (AASHTO T 315-02) & Medir as propriedades reológicas do asfalto sob \\
Rotational Viscosimeter (RV) (ASTM D 4402) & Medir as propriedades de trabalhabilidade do \\
Bending Beam Rheometer (BBR) (ASTM 6648-01) & asfalto sob altas temperaturas \\
Direct tensión tester (DTT) (ASTM P 252) & Medir as propriedades reológicas do asfalto sob \\
&
\end{tabular}

\subsubsection{Análise comparativa da caracterização e classificação dos asfaltos por penetração e pelo método Superpave}

As principais diferenças entre os dois métodos são:

1. Superpave utiliza propriedades fundamentais do material para classificá-lo, enquanto que o método convencional por penetração utiliza diretamente o resultado numérico do ensaio de penetração (o que não representa nenhuma propriedade básica ou de comportamento do asfalto); 
2. Superpave define primeiro os requisitos mínimos do asfalto com relação as suas propriedades reológicas e estes se verificam nas temperaturas reais do campo. No método por penetração o asfalto é ensaiado a temperaturas totalmente arbitrárias, não representativas das condições de campo. Porém, com o conceito de susceptibilidade térmica é possível estimar algumas propriedades de consistência;

3. Superpave considera nos ensaios a condição dinâmica estabelecendo diferentes freqüências e tempos de aplicação da carga. No método de classificação por penetração, nenhum dos ensaios tradicionais é dinâmico e não consideram a variável tempo de carga;

4. Superpave considera dois métodos para simular o envelhecimento do ligante. Um representa as etapas de usinagem, transporte e aplicação das misturas a quente (RTFOT) e o outro (PAV) representa o envelhecimento em longo prazo (durante a vida em serviço). O método de penetração só considera o envelhecimento em curto prazo (RTFOT);

5. Superpave pode ser aplicado a todos os tipos de asfalto enquanto que o método de penetração, por conter ensaios de pureza e constituição do asfalto, muitas vezes rejeita alguns asfaltos por não atender as exigências desses parâmetros;

6. A viscosidade em alta temperatura, que é importante nos processos de bombeamento e misturado do ligante, além da aplicação e compactação das misturas, é medida no método Superpave com o viscosímetro rotacional (viscosidade dinâmica) e no método por penetração com o viscosímetro capilar (viscosidade cinemática). 


\subsection{MISTURAS ASFÁLTICAS}

O concreto asfáltico e o concreto asfáltico com asfalto modificado por polímero são misturas a quente executadas em usina apropriada com características específicas de agregado mineral graduado, material de enchimento (fíler) e ligante asfáltico ou ligante asfáltico de petróleo modificado por polímero, aplicadas e compactadas a quente (DNER-ES 313/97 e DNER-ES 385/99).

Segundo Carpenter e Vandam (1987), o fator principal para o uso de asfaltos modificados por polímeros é elevar o nível de desempenho dos pavimentos em campo, devendo essa melhora de desempenho compensar qualquer acréscimo nos custos associados à incorporação dos polímeros aos cimentos asfálticos de petróleo.

\subsubsection{Distribuição granulométrica das misturas asfálticas.}

A distribuição granulométrica está relacionada com o desempenho de uma mistura asfáltica a curto, médio e longo prazo. Tem influência na estabilidade, durabilidade, permeabilidade, trabalhabilidade, resistência à fadiga, resistência à deformação permanente e na resistência aos danos causados pela umidade. Portanto, a graduação, assim como as especificações a ela relacionadas, deve ser considerada como sendo o primeiro passo para a elaboração de uma mistura asfáltica.

Dentre os vários tipos de graduação para misturas asfálticas, destacam-se as misturas com graduação contínua, onde a resistência é alcançada através da maior densidade possível, e as 
graduações descontínuas, onde o agregado graúdo forma o esqueleto resistente da mistura. A Figura 2.7 apresenta os tipos de curvas granulométricas para misturas asfálticas.

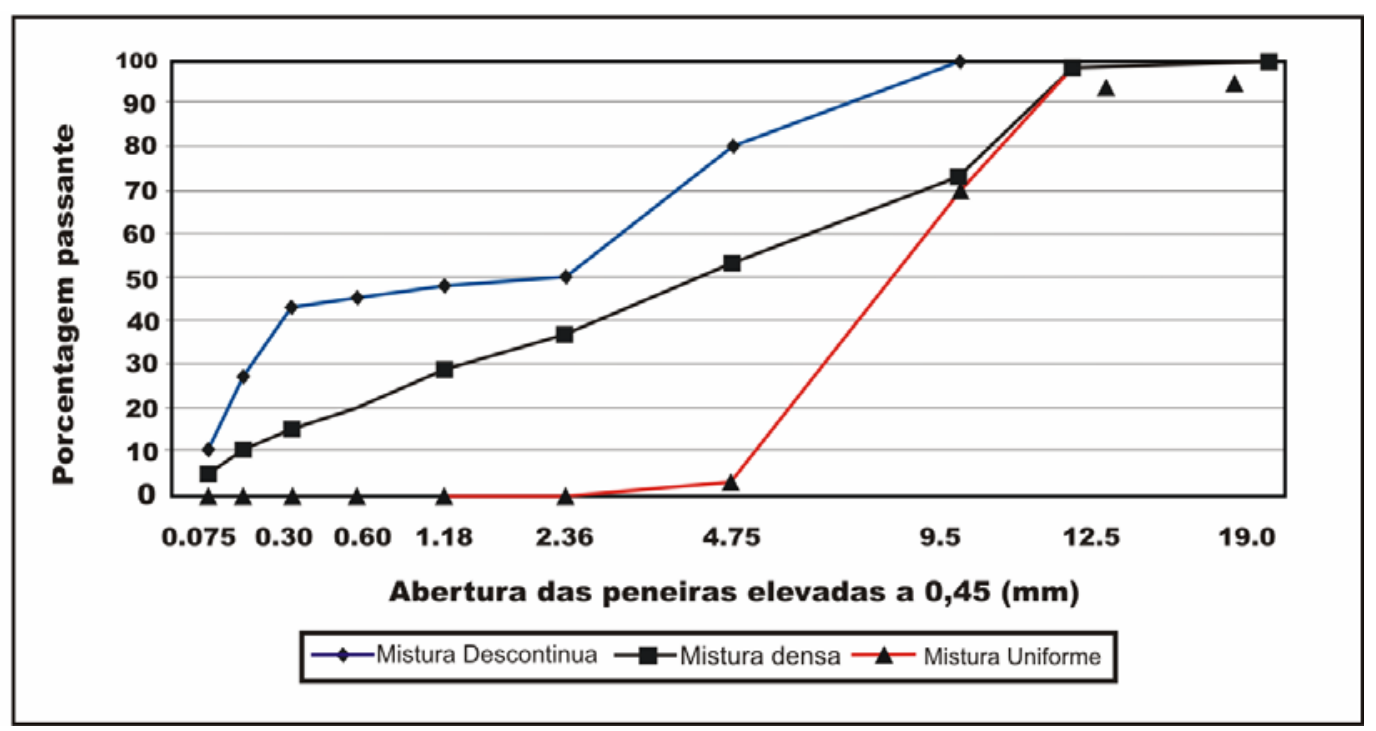

Figura 2.7 - Tipos de curvas granulométricas para misturas asfálticas.

Fonte: ROBERTS, et al. 1991

\subsubsection{Graduação Contínua}

Uma graduação continua é aquela onde as partículas de agregados ficam completamente adensadas, seria a melhor em termos de estabilidade, devido ao aumento do contato entre as partículas e à diminuição dos vazios na mistura. Porém, é necessário um volume de vazios suficiente para a adição do ligante asfáltico, capaz de assegurar maior coesão e durabilidade à mistura, além de um adequado volume de vazios necessário para evitar a exsudação do ligante asfáltico e/ou à deformação permanente da mistura sob a ação de cargas do tráfego. Ou seja, uma mistura asfáltica com baixo volume de vazios é mais sensível a pequenas variações na quantidade de asfalto e, portanto, mais susceptível à exsudação e à deformação permanente. 


\subsubsection{Graduação Descontínua}

A mistura asfáltica de graduação descontínua apresenta uma grande proporção de agregado graúdo e fíler mineral, e uma pequena proporção de agregados médios como é o caso de uma mistura SMA ou CMHB (Coarse Matrix High Binder). Essas misturas resistem às cargas do tráfego não com a máxima densidade possível, mas sim com uma grande quantidade de agregado graúdo formando o esqueleto da mistura. Com um forte contato entre as partículas de agregado graúdo, o que permite que a resistência à deformação permanente aumente. Uma mistura descontínua SMA ou CMHB possui maior quantidade de asfalto que as misturas contínuas. Essa maior quantidade de asfalto, juntamente com a grande quantidade de fíler, preenche os vazios deixados pelo esqueleto de agregado graúdo e contribuem muito para a resistência ao aparecimento e propagação de trincas por fadiga.

Uma mistura asfáltica de graduação descontínua, tipo SMA ou CMHB, pode ter um melhor desempenho que uma mistura de graduação contínua ou densa, pois a grande quantidade de agregado graúdo aumenta a resistência à deformação permanente, enquanto a grande quantidade de fíler e asfalto aumentam a resistência ao desgaste. Porém, em qualquer tipo de mistura as propriedades físicas dos agregados (forma, textura superficial, angularidade etc.) têm grande importância no seu desempenho. Em misturas descontínuas, a importância da qualidade dos agregados é ainda maior.

\subsubsection{Graduação Superpave}

Os pesquisadores do SHRP refinaram as especificações da graduação existentes e desenvolveram planilhas de graduação baseados na equação de Fuller, que apresenta as curvas de máxima densidade (e mínimo VAM) para cada tamanho de agregados. 
Como produto da utilização desta equação se obtém misturas de fácil compactação, mas com tendência de ser muito frágeis e de possuir poucos vazios. O método Superpave utiliza planilhas nas quais se tem pontos de controle e uma zona de restrição. Nestas planilhas, o tamanho das peneiras foi elevado a potência 0.45 , onde a curva de máxima densidade fica representada por uma reta, que vai desde a origem das abcissas e ordenadas até a peneira pela qual passa o $100 \%$ dos agregados (tamanho máximo). A Figura 2.8. apresenta um exemplo de granulometria superpave.

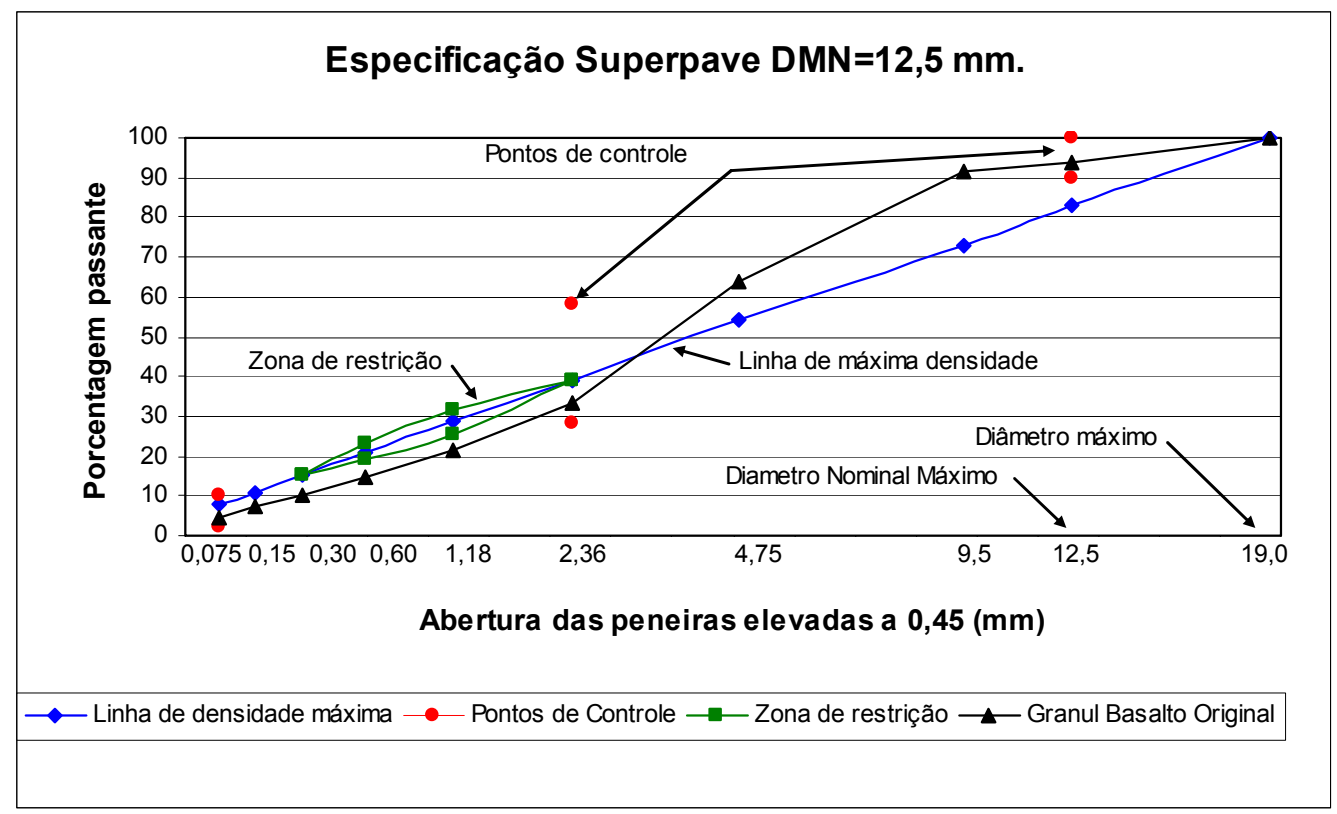

Figura 2.8 - Exemplo de granulometria Superpave.

A granulometria composta deve passar através dos pontos de controle, o que assegura uma determinada quantidade de vazios para preenchimento com asfalto. Porém, a curva granulométrica dos agregados não deve passar pela zona de restrição (SHRP recomenda passar por baixo dela) o que evita misturas de agregados com uma alta proporção de areia fina. Curvas granulométricas muito próximas da linha de densidade máxima devem ser evitadas por não apresentarem um adequado volume de vazios. Uma granulometria que cruze a zona de restrição tem, a princípio, um esqueleto mineral frágil e pode apresentar problemas 
na compactação e baixa resistência à deformação permanente. Porém, segundo Kandhal \& Mallik (2001), há alguns tipos de agregados, como agregados de origem calcária e granítica, que com graduação passando abaixo da zona de restrição apresentaram maior quantidade de deformação permanente, em relação aos que passaram através da zona de restrição os quais apresentaram as menores quantidades de deformação permanente. Já a graduação que passou acima da zona de restrição apresentou uma quantidade intermediária de deformação permanente.

Watson et al. (1997) reportaram que quatro das misturas convencionais de graduação densa mais utilizadas no Departamento de Transportes do Estado da Geórgia utilizam misturas asfálticas compostas de agregados com graduações que violam a zona de restrição, mas que atendem as demais recomendações e exigências das especificações Superpave, isso mostra que determinados agregados que passam através da zona de restrição apresentam excelente desempenho em campo.

Kandhal e Cooley Jr. (2001 e 2002), em pesquisa que conta com a análise de 2 tipos de agregado graúdo, 10 tipos de agregado miúdo e 5 granulometrias (3 passando pela zona de restrição), concluíram que a zona de restrição deveria ser eliminada das especificações Superpave, pois misturas que violam esta zona, mas que se enquadram nos limites de angularidade de agregados miúdos (FAA, fine aggregate angularity) e nos demais ensaios da especificação de agregados, apresentam desempenho igual ou superior ao de misturas que atendem ao requisito da zona de restrição. Finalmente o Superpave Mixture and Aggregate Expert Task Group (ETG) recomendou que a zona de restrição deveria ser retirada dos procedimentos do Superpave e deveriam também ser retiradas da AASHTO MP2 e PP28 (SUPERPAVE ETG, 2001). 


\subsubsection{Influência da graduação no Desempenho de Misturas Asfálticas}

Segundo o Instituto do Asfalto (1989), os agregados representam em torno de 95\% em peso e 70 a $85 \%$ em volume de toda a mistura asfáltica e contribuem significativamente para o desempenho da mistura. Suas características influenciam diretamente nas propriedades volumétricas e como conseqüência nas propriedades de rigidez, resistência ao cisalhamento e na vida de fadiga.

\subsubsection{Misturas asfálticas Metodologia Marshall}

Segundo de Senço (1997), o método Marshall foi desenvolvido em 1930 pelo Departamento de Estradas de Rodagem do estado de Mississipi, nos Estados Unidos da América do Norte, tendo como objetivo determinar a quantidade ótima de ligante betuminoso utilizado numa mistura betuminosa.

Ao longo dos anos foi modificado para adaptar-se à realidade do aumento de carga de roda e pressão dos pneus dos veículos e dentre as modificações foram sugeridos novos critérios para a determinação da quantidade ótima de ligante asfáltico, que deveria ser a mais próxima dos valores correspondentes à estabilidade e densidade aparente máximas, além dos outros parâmetros como porcentagem de vazios, relação betume/vazios, estabilidade e fluência terem tido seus valores modificados para a nova realidade. Os parâmetros usados no método Marshall para misturas asfálticas usinadas a quente devem-se enquadrar nos limites mostrados na Tabela 2.6. 
Tabela 2.6 - Ensaio Marshall - Valores limites para misturas convencionais.

\begin{tabular}{cll}
\hline Discriminação & Camada de Rolamento & Camada de Ligação (Binder) \\
\hline Porcentagem de vazios (\%) & 3 a 5 & 4 a 6 \\
Relação Betume/vazios (\%) & $75 / 82$ & $65 / 72$ \\
& 350 (75 golpes) & 350 (75 golpes) \\
Estabilidade mínima (kgf) & 250 (50 golpes) & 250 (50 golpes) \\
Fluência (mm) & 2,0 a 4,5 & 2,0 a 4,5 \\
\hline
\end{tabular}

Fonte: DNER-ES 313/97

Os parâmetros usados no método Marshall para misturas betuminosas usinadas a quente com asfalto modificado por polímero tem que se enquadrar nos limites mostrados na Tabela 2.7 .

Tabela 2.7 - Ensaio Marshall - Valores limites para misturas modificadas por polímero.

\begin{tabular}{cll}
\hline Discriminação & Camada de Rolamento & Camada de Ligação (Binder) \\
\hline Porcentagem de vazios (\%) & 3 a 5 & 4 a 6 \\
Relação Betume/vazios (\%) & $75 / 82$ & $65 / 72$ \\
Estabilidade mínima (kgf) & 500 (75 golpes) & 500 (75 golpes) \\
Fluência (mm) & 2,0 a 4,5 & 2,0 a 4,5 \\
Resistência a tração por compressão & 7,0 a 12,0 & 7,0 a 12,0 \\
diametral a $25^{\circ} \mathrm{C}\left(\mathrm{kgf} / \mathrm{cm}^{2}\right)$ & & \\
\hline
\end{tabular}

Fonte: DNER-ES 385/99.

No ensaio Marshall, a dosagem de misturas asfálticas é feita considerando-se valores admissíveis empíricos para a estabilidade e a fluência.

Segundo Bertollo, (2002) na dosagem das misturas asfálticas, o método Marshall considera os seguintes parâmetros:

- granulometria: busca-se a densidade máxima possível para garantir a máxima estabilidade; 
- densidade aparente da mistura: calculada com os corpos de prova do ensaio de dosagem;

- densidade máxima teórica da mistura: densidade da mistura suposta sem vazios;

- porcentagem de vazios da mistura $\left(\mathrm{V}_{\mathrm{a}}\right)$ : volume total de pequenas bolsas de ar existentes entre as partículas de agregados recobertos por cimento asfáltico em uma mistura compacta em relação ao volume total da mistura;

- porcentagem de vazios do agregado mineral (VAM): porcentagem do volume do espaço intergranular de uma mistura asfáltica compactada, que inclui o volume de ar e de asfalto, em relação ao volume total da mistura;

- relação betume vazios (RBV): porcentagem do volume de VAM que é preenchido com cimento asfáltico;

- estabilidade: carga, em kgf, sob o qual o corpo de prova rompe quando submetido à compressão diametral;

- fluência: deformação total, em décimos de milímetro ou centésimos de polegada, que o corpo de prova sofre ao romper.

\subsubsection{Misturas asfálticas método Superpave}

Duas características importantes do método de projeto Superpave são:

- o acondicionamento da mistura

- a compactação efetuada no laboratório

As misturas asfálticas que são utilizadas para moldar os corpos de prova são acondicionadas durante duas horas dentro de uma estufa a temperatura de compactação (as temperaturas de 
mistura e compactação se determinam igual ao método de projeto Marshall, em função da viscosidade do asfalto); o que permite simular o envelhecimento a "curto prazo" que se produz durante o processo de armazenagem e transporte da mistura asfáltica, além disso, fornece tempo ao agregado para absorver o ligante asfáltico.

A compactação em laboratório é realizada fazendo uso do Compactador Giratorio Superpave (Superpave Gyratory Compactor - SGC) mostrado na Figura 2.9. Este aparelho efetua uma rotação com um ângulo de inclinação de 1.25 graus e aplica sobre a mistura uma pressão de confinamento de $600 \mathrm{kPa}$. A soma de ambos os fatores simula o efeito produzido pelos rolos compactadores (o número de rotações requeridas, $\mathrm{N}_{\text {DIS }}$, é especificado na norma AASHTO TP4-93).

O SGC incorpora um software que indica a altura do corpo de prova e o número de revoluções, o que permite determinar o grau de compactação do corpo de prova durante todo o processo de compactação, sendo necessário inserir como dados iniciais, o peso e a densidade máxima da mistura.

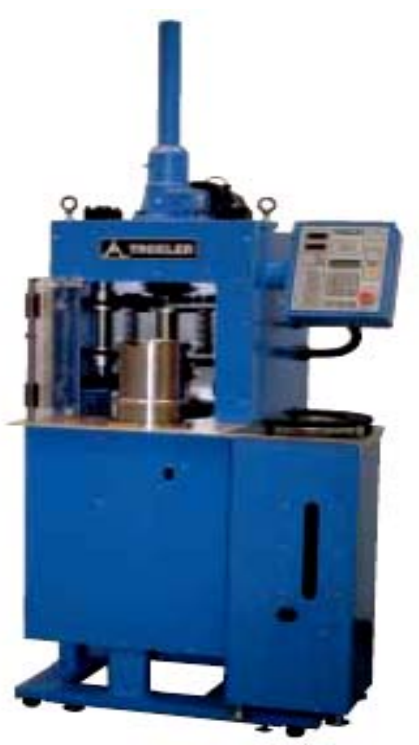

Figura 2.9 - Compactador Giratório Superpave 


\subsubsection{Requisitos volumétricos da mistura}

Uma vez selecionados os materiais (ligantes asfálticos e agregados minerais), definem-se os requisitos volumétricos da mistura e o teor de pó. Os pesquisadores que desenvolveram o Superpave consideram que as proporções volumétricas dos componentes da mistura asfáltica (ligantes e agregados) são importantes.

Os requisitos volumétricos da mistura constituem-se de: Vazios na Mistura, Vazios no Agregado Mineral e Vazios Preenchidos por Asfalto (VFA). Estes devem obedecer aos seguintes requisitos:

- vazios na Mistura $\left(\mathrm{V}_{\mathrm{a}}\right)$ : no Superpave, o teor de vazios de projeto na mistura é de 4\%;

- vazios no Agregado Mineral (VAM): Para um projeto com 4\% de $\mathrm{V}_{\mathrm{a}}$, o VAM é especificado em função do tamanho nominal máximo do agregado, conforme a Tabela 2.8 (AASHTO MP2, 2001);

- vazios Preenchidos com Asfalto (VFA ou RBV): Para um projeto com 4\% de $\mathrm{V}_{\mathrm{a}}$, a RBV é especificado em função do volume de tráfego (ESAL) conforme Tabela 2.9 (AASHTO MP2, 2001);

Tabela 2.8 - Recomendações SUPERPAVE para Vazios no Agregado Mineral.

\begin{tabular}{cc}
\hline Tamanho Nominal Máximo do Agregado & VAM mínimo (\%) \\
\hline $9,5 \mathrm{~mm}$ & 15,0 \\
$12,5 \mathrm{~mm}$ & 14,0 \\
$19 \mathrm{~mm}$ & 13,0 \\
$25 \mathrm{~mm}$ & 12,0 \\
$37,5 \mathrm{~mm}$ & 11,0 \\
\hline
\end{tabular}


Tabela 2.9 - Recomendações SUPERPAVE para Vazios Preenchidos com Asfalto.

\begin{tabular}{cc}
\hline Tráfego, ESALs & RBV de Projeto (\%) \\
\hline$<3 \times 10^{5}$ & $70-80$ \\
$3 \times 10^{5}<\mathrm{ESAL}<3 \times 10^{6}$ & $65-78$ \\
$>3 \times 10^{6}$ & $65-75$ \\
\hline
\end{tabular}

Fonte: AASHTO MP2, 2001

Segundo Kandhal et al. (1998), uma das principais dificuldades encontradas pelos orgãos rodoviários nos Estados Unidos da América (EUA), quando da implementação do projeto volumétrico de misturas Superpave, está em satisfazer o VAM mínimo especificado de acordo com o tamanho nominal máximo do agregado. Os VAM dessas misturas estão relacionadas ao aumento do esforço de compactação proporcionado pelo compactador giratório e ao uso de misturas mais grossas, com graduação abaixo da zona de restrição, conforme recomenda a especificação para rodovias com alto volume de tráfego. Também salientam que o valor mínimo de VAM recomendado na especificação Superpave para assegurar a durabilidade da mistura é inadequado, pois penaliza misturas de graduação grossa (que passam abaixo da zona de restrição). Essas misturas podem ter baixo valor de VAM e, ao mesmo tempo, apresentar um aumento na espessura da película de asfalto que recobre o agregado. Os autores recomendam que a espessura mínima do filme de asfalto seja utilizada para assegur a durabilidade da mistura, ao invés de um VAM mínimo. Sugerem, como último passo do projeto de dosagem Superpave, o cálculo da espessura do filme de asfalto que deverá ser maior ou igual a $8 \mu \mathrm{m}$.

O Superpave especifica uma faixa de aceitação para o teor de Pó (TF - Teor de filer) que é definido como a razão entre a \% passante na peneira $n^{\circ} 200$ e o teor efetivo de asfalto expresso em relação à mistura total, apresentado na equação 2.1. Este teor de filer é usado como um critério de projeto, onde o teor aceitável de filer pode variar segundo as últimas 
mudanças no Superpave entre 0,6 e 1,2 para as misturas em geral, podendo ser aumentados para 0,8 a 1,6 se a graduação dos agregados passar abaixo dos limites da zona restrita. Com esta permissão, uma quantidade maior de material mais fino que $0,075 \mathrm{~mm}$ poderá ser utilizada.

$$
\mathrm{TF}=\frac{P_{.075}}{P_{b e}}
$$

onde:

$\mathrm{P}_{.075}=\%$ passante na peneira $\mathrm{n}^{\circ} 200$ da massa do agregado

$\mathrm{P}_{\mathrm{be}} \quad=$ teor efetivo de asfalto $(\%$ em peso $)$

A especificação AASHTO MP2 (2001) ainda fixa limites para porcentagem da Densidade máxima medida $(\% \mathrm{Gmm})$ que é obtida pela mistura para o número de giros inicial $\left(\mathrm{N}_{\mathrm{ini}},\right)$, de projeto $\left(\mathrm{N}_{\text {projeto }}\right)$ e máximo $\left(\mathrm{N}_{\max }\right)$. Estes limites podem ser vistos na Tabela 2.10 .

Tabela 2.10 - Recomendações Superpave para a porcentagem da Densidade Máxima Medida

\begin{tabular}{|c|c|c|c|}
\hline \multirow{2}{*}{ Tráfego ESALs } & \multicolumn{3}{|c|}{ Densidade (\%Gmm) } \\
\hline & $\mathbf{N}_{\text {ini }}$ & $\mathbf{N}_{\text {projeto }}$ & $\mathbf{N}_{\max }$ \\
\hline$<3 \times 10^{5}$ & $\leq 91,5$ & & \\
\hline $3 \times 10^{5}$ a $3 \times 10^{6}$ & $\leq 90,5$ & & \\
\hline $3 \times 10^{6}$ a $1 \times 10^{7}$ & & 96,0 & $\leq 98,0$ \\
\hline $1 \times 10^{7}$ a $3 \times 10^{7}$ & $\leq 89,0$ & & \\
\hline$>\mathbf{3} \times 10^{7}$ & & & \\
\hline
\end{tabular}

Fonte: AASHTO MP2, 2001

Todas as informações são analisadas e comparadas com os critérios preconizados no Superpave, qualquer combinação que obedecer a esses critérios poderá ser selecionada. O 
propósito desta etapa é determinar uma combinação econômica de agregados e ligante que irá proporcionar um bom desempenho do pavimento.

\subsection{PRINCIPAIS DEFEITOS DE UM PAVIMENTO FLEXÍVEL}

Um pavimento flexível ao longo de seu período de vida útil está sujeito a uma redução na sua capacidade estrutural e funcional. Dentre os defeitos, os mais importantes são: deformação permanente, trincas por fadiga, trincas a baixas temperaturas e o desgaste.

\subsubsection{Deformação Permanente}

A deformação permanente nos pavimentos resulta da aplicação de cargas repetidas, que acontecem a cada passagem de um veiculo, sendo um processo acumulativo. Segundo Anani, Balghunaim e Al-hazzaa (1990), são muitos os fatores que interferem na ocorrência de deformações permanentes, podendo-se citar o volume de tráfego pesado, a pressão de enchimento dos pneus, a temperatura de serviço do pavimento, as práticas construtivas e os fatores internos, relacionados às características das camadas do pavimento.

Porém, as duas razões principais para o afundamento da trilha de roda nos pavimentos revestidos com misturas asfálticas são: estrutural, resultante das contribuições de todas as camadas e o subleito, geradas pelo mau dimensionamento e misturas asfálticas com baixa resistência ao cisalhamento, o que depende da susceptibilidade térmica do ligante asfáltico e do esqueleto do agregado mineral. 
Nos Estados Unidos as pesquisas realizadas na pista experimental da American Association of State Highway Officials (AASHO), verificou-se que, em média, o revestimento responde por cerca de $32 \%$ da deformação permanente total, a base por cerca de $14 \%$, a sub-base por $45 \%$ e apenas 9\% ocorre em razão da deformação do subleito do pavimento (HIGHWAY RESEARCH BOARD, 1962).

No Brasil a maior parte da deformação permanente de um pavimento deve-se a esforços cisalhantes que ocorrem na parte superior da camada de concreto asfáltico. Assim, as misturas asfálticas com elevados teores de ligante e poucos vazios (menos de $4 \%$ ) estão sujeitas a deformações permanentes por movimentação plástica, que se caracteriza por afundamento no centro das trilhas de roda, acompanhado por pequenas elevações laterais. Isso ocorre porque a redução do volume de vazios, em conseqüência do aumento do teor de ligante, indica que os espaços vazios estão preenchidos com ligante o que faz com que este se torne praticamente um lubrificante entre as partículas do agregado. A suscetibilidade às deformações permanentes de misturas com essas características se agrava em temperaturas elevadas quando o ligante asfáltico passa a facilitar ainda mais as deformações por cisalhamento (GRECO, 2004).

$\mathrm{Na}$ Tabela 2.11 apresenta-se um resumo dos principais fatores que podem afetar $\mathrm{o}$ desempenho de misturas asfálticas quanto à deformação permanente. 
Tabela 2.11 - Fatores que interferem no desempenho de misturas asfálticas quanto à deformação permanente.

\begin{tabular}{|c|c|c|c|}
\hline & Fator & Variação do fator & $\begin{array}{l}\text { Efeito na resistência à } \\
\text { deformação permanente }\end{array}$ \\
\hline \multirow{4}{*}{ Agregado } & - Textura superficial. & - Lisa para rugosa & - Aumento \\
\hline & - Granulometria & - Aberta para contínua & - Aumento \\
\hline & - Forma & - Redonda para angulosa & - Aumento \\
\hline & - Tamanho & $\begin{array}{l}\text { - Aumento do tamanho } \\
\text { máximo }\end{array}$ & - Aumento \\
\hline Ligante & - Rigidez ${ }^{a}$ & - Aumento & - Aumento \\
\hline \multirow{4}{*}{ Mistura } & - Quantidade de ligante & - Aumento & - Redução \\
\hline & - Volume de vazios ${ }^{\mathrm{b}}$ & - Aumento & - Redução \\
\hline & - Vazios no agregado mineral & - Aumento & - Redução ${ }^{c}$ \\
\hline & - Método de compactação & d & d \\
\hline \multirow{4}{*}{$\begin{array}{l}\text { Condições } \\
\text { de ensaio }\end{array}$} & - Temperatura & - Aumento & - Redução \\
\hline & - Estado de tensão/deformação & $\begin{array}{l}\text { - Aumento da pressão de } \\
\text { contato dos pneus }\end{array}$ & - Redução \\
\hline & - Repetição do carregamento & - Aumento & - Redução \\
\hline & - Água & - Seco para molhado & $\begin{array}{l}\text { - Redução se a mistura for } \\
\text { sensível à água }\end{array}$ \\
\hline
\end{tabular}

a) Refere-se à rigidez na temperatura em que a suscetibilidade à deformação permanente está sendo avaliada. Modificadores podem ser adicionados ao ligante para aumentar sua rigidez em temperaturas críticas, reduzindo assim a propensão a deformações permanentes;

b) Quando o volume de vazios é inferior a 3\%, a susceptibilidade à deformação permanente aumenta;

c) Questiona-se atualmente se valores muito baixos de VAM (por exemplo, inferiores a 10\%) devem ser evitados;

d) O método de compactação, em campo ou em laboratório, pode influenciar na estrutura do material e consequentemente em sua suscetibilidade à deformação permanente.

Fonte: Sousa, Craus, e Monismith (1991)

$\mathrm{O}$ asfalto modificado por polímero tem mostrado uma redução das deformações permanentes. Segundo Valkering et al. (1990), a modificação do asfalto com polímero SBS mostrou uma redução de 60 a $70 \%$ da profundidade de trilhas de rodas na camada de mistura asfáltica, através de resultados obtidos do "Laboratory Test Track - LTT" e do ensaio de fluência dinâmico. Ensaios laboratoriais realizados por Tayebali et al. (1992), apresentaram menor 
deformação plástica acumulada para misturas contendo asfalto modificado do que as misturas asfálticas convencionais, indicando uma redução no potencial de formação de trilha de roda. A Figura 2.10 apresenta um caso típico de deformação permanente da capa asfáltica nas trilhas de roda.

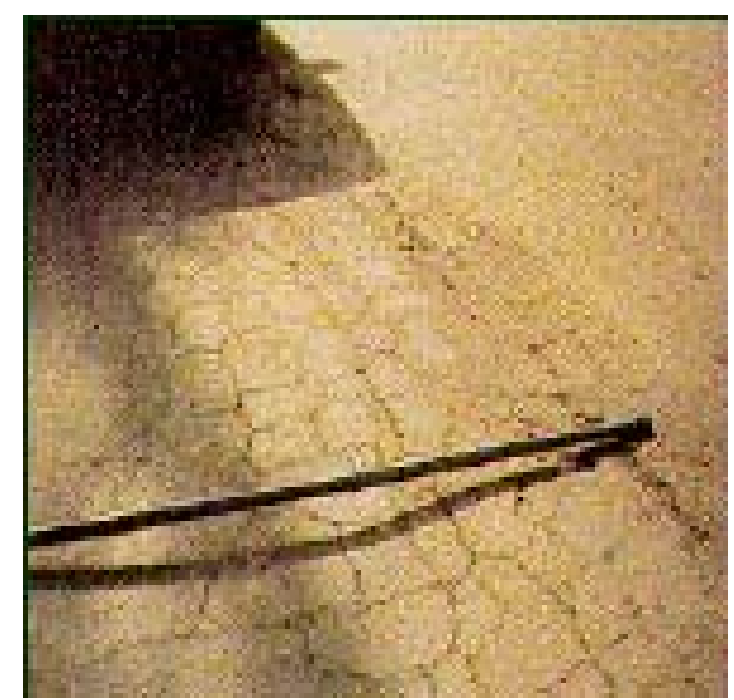

Figura 2.10 - Deformação permanente nas trilhas de roda

\subsubsection{Trincas por fadiga}

A vida de fadiga de um material asfáltico pode ser apresentada como o número de aplicações de carga necessário para que a mistura atinja ruptura, sob dado estado de tensões. O fenômeno da fadiga pode ser descrito, tecnicamente, como a diminuição gradual da resistência de um material por efeito de solicitações repetidas, ou o carregamento e descarregamento constante do pavimento, devido à ação do tráfego, que gera deformações elásticas. Com a movimentação constante de deformação e recuperação surgem tensões de tração nas fibras inferiores da capa asfáltica do pavimento, que induzem um dano ao material em cada ciclo, que se acumulam até finalmente produzir a ruptura, como é mostrado na Figura 2.11. 


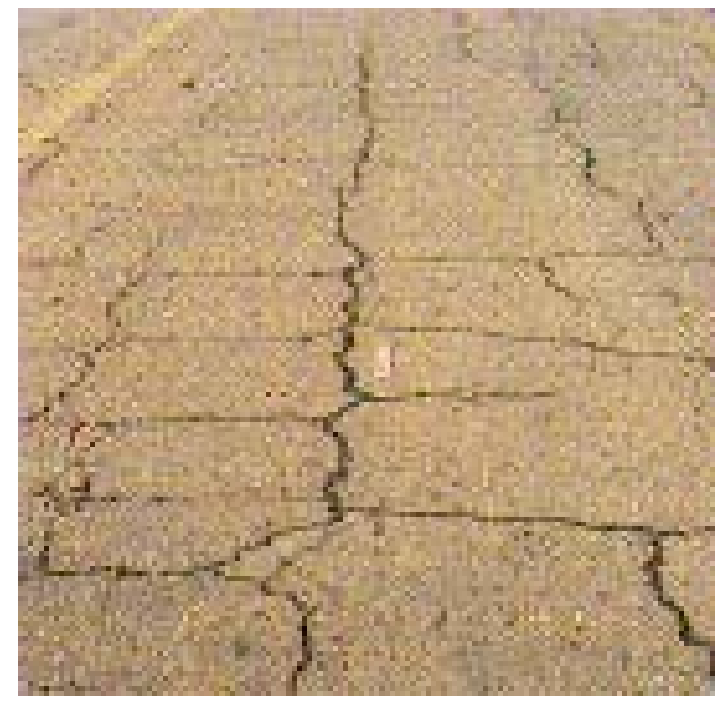

Figura 2.11 - Trincas por fadiga

Segundo Brown, Kandhal e Zhang (2001), o trincamento por fadiga acontece quando o pavimento é tensionado ao limite da sua vida de fadiga.

Segundo Gontijo (1980), os principais fatores intervenientes são:

- características do tráfego: carga por roda, pressão do contato, velocidade do veículo, intensidade do tráfego;

- características próprias do pavimento: espessura e rigidez das camadas;

- condições climáticas, em particular a temperatura.

De uma maneira geral as tensões de tração que se desenvolvem nas camadas inferiores do pavimento:

- diminuem com o aumento da temperatura e conseqüentemente com o decréscimo do módulo de rigidez;

- diminuem com o aumento do módulo da base; 
- variam relativamente pouco com a espessura da camada de base (quando esta é superior a $20 \mathrm{~cm}$ ) e com o módulo do solo de fundação;

- diminuem com o aumento da espessura do próprio revestimento e aumentam com o acréscimo do módulo de rigidez do concreto asfáltico.

Em resumo a vida de fadiga dos pavimentos de concreto asfáltico depende da rigidez da mistura, conteúdo de asfalto, ponto de amolecimento, viscosidade, graduação do agregado, textura do agregado, processo construtivo, tráfego e clima. (KIN, Y.R.; KIN, N. \& KHOSLA.; 1992, TIGDEMIR, KALYONCUOGLU S. F. \& KALYONCUOGLU U. Y.; 2004).

A Tabela 2.12 mostra como alguns fatores influenciam a vida de fadiga das misturas asfálticas. 
Tabela 2.12 - Fatores que afetam a rigidez na vida de fadiga das misturas asfálticas

\begin{tabular}{|c|c|c|c|c|}
\hline \multirow[b]{2}{*}{ Fator } & \multirow[b]{2}{*}{ Variação do fator } & \multicolumn{3}{|c|}{ Efeito de variação do fator } \\
\hline & & Rigidez & $\begin{array}{c}\text { Vida de fadiga } \\
\text { em tensão } \\
\text { controlada (TC) }\end{array}$ & $\begin{array}{c}\text { Vida de fadiga em } \\
\text { deformação } \\
\text { controlada(DC) }\end{array}$ \\
\hline $\begin{array}{l}\text { Penetração do } \\
\text { asfalto }\end{array}$ & Decresce & Aumenta & Aumenta & Decresce \\
\hline Teor de ligante & Aumento & Aumenta $^{(a)}$ & Aumenta $^{(a)}$ & Aumenta $^{(\mathrm{b})}$ \\
\hline Tipo de agregado & $\begin{array}{c}\text { Aumenta a rugosidade } \\
\text { e angularidade }\end{array}$ & Aumenta & Aumenta & Decresce \\
\hline $\begin{array}{l}\text { Granulometria do } \\
\text { agregado }\end{array}$ & Aberta a densa & Aumenta & Aumenta & Decresce $^{(b)}$ \\
\hline Índice de vazios & Decresce & Aumenta & Aumenta & Decresce $^{(b)}$ \\
\hline Temperatura & Decresce & Aumenta $^{(\mathrm{c})}$ & Aumenta & Decresce \\
\hline
\end{tabular}

(a) Existe um teor ótimo para vida de fadiga máxima.

(b) Poucos estudos existentes.

(b) Aproximações limitam abaixo da temperatura de congelamento.

Fonte: Monismith et al. (1990).

\subsubsection{Trincas térmicas}

O trincamento de pavimentos asfálticos por contração a baixas temperaturas é um fenômeno comum em regiões frias. Em províncias canadenses e norte dos Estados Unidos as trincas manifestam-se como uma série de trincas transversais que se estendem pela superfície do pavimento perpendiculares à direção do tráfego espaçadas em forma quase constante como é mostrado na Figura 2.12.

Yoder e Witczak, (1975) perceberam que aqueles intervalos de trincas térmica de 6 a 9 m é típico, mas pode variar de menos de $1 \mathrm{~m}$ até $30 \mathrm{~m}$. É um trincamento que ocorre quando uma camada de pavimento asfáltico contrai em uma estação fria em razão da queda de 
temperatura. Pode ser o resultado de uma queda de temperatura até a temperatura crítica de trincamento, como também pode ser causado por apenas vários ciclos de subida e descida de temperatura (fadiga térmica). A magnitude e freqüência de baixas temperaturas e a rigidez da mistura asfáltica na superfície são os fatores principais na ocorrência e intensidade de trincamento transversal por baixa temperatura.

É amplamente reconhecido que o ligante asfáltico é o contribuinte primário para a resistência ao trincamento, pois a baixa temperatura, o ligante asfáltico se comporta de uma maneira frágil e perde a habilidade de absorver energia por fluxo viscoso.

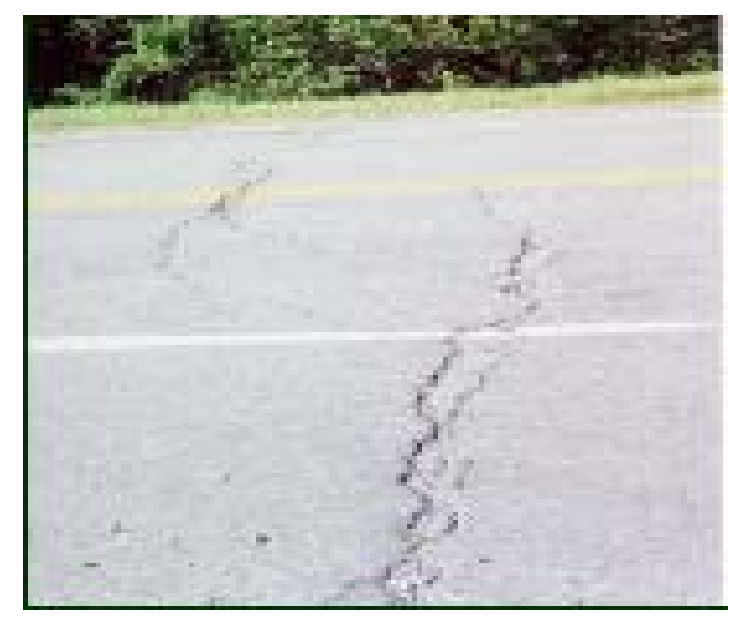

Figura 2.12 - Trincas por baixa temperatura 
Só se pode vencer a natureza obedecendo-lhe.

(Francis Bacon) 


\section{CAPÍTULO III}

\section{ESTUDO E DISTRIBUIÇÃO DO GRAU DE}

\section{DESEMPENHO DE LIGANTES}

\section{ASFÁLTICOS DO PERU}

\subsection{CONSIDERAÇÕES INICIAIS}

O Programa SHRP (Strategic Highway Research Program) resultou na especificação de ligantes asfálticos que se baseia no desempenho e classifica os ligantes de acordo com as condições climáticas e o tipo de solicitação do tráfego a que o pavimento será submetido. Dados como temperatura máxima do pavimento durante sete dias seguidos, temperatura mínima do pavimento, confiabilidade, tempo de carregamento e volume de tráfego são usados na especificação de ligantes Superpave para selecionar o ligante apropriado para o trabalho a ser realizado, sendo que a classificação determina o Grau de Desempenho (PG - Performance Grade) do ligante.

O objetivo deste capítulo é estabelecer o grau de desempenho do ligante asfáltico mais indicado para uso em pavimentação nas diferentes regiões do Peru. As temperaturas máximas e mínimas foram obtidas da base de dados do SENAMHI (Servicio Nacional de Meteorologia e Hidrologia - Peru), que conta com informações de 120 estações meteorológicas distribuídas pelo território peruano. As temperaturas do pavimento foram calculadas através das temperaturas do ar, medidas nas estações meteorológicas, usando-se modelos desenvolvidos 
durante o SHRP e, posteriormente, pelo LTPP (Long-Term Pavement Performance). Foram realizadas análises de confiabilidade e o PG dos ligantes foi estabelecido em incrementos de $6^{\circ} \mathrm{C}$ (por exemplo, 52, 58, 64, 70 e 76 no lado das temperaturas altas e -10 , -16 e -22 no lado das temperaturas baixas).

\subsection{ALGUMAS CONSIDERAÇÕES SOBRE O ESTUDO E SELEÇÃO DO GRAU DE DESEMPENHO DO LIGANTE ASFÁlTICO PROPOSTAS PELO SHRP}

Uma parte importante do Superpave são as especificações para a seleção dos ligantes asfálticos, definidas por seu grau de desempenho $P G \mathrm{~T}_{\mathrm{MAX}}-\mathrm{T}_{\mathrm{MIN}}$,

Onde:

PG = Grau de Desempenho (Performance Grade)

$\mathrm{T}_{\mathrm{MAX}}=$ Temperatura Máxima (na qual o asfalto deve manter suas propriedades durante o serviço).

$\mathrm{T}_{\mathrm{MIN}}=$ Temperatura Mínima (na qual o asfalto deve manter suas propriedades durante o serviço).

Para realizar um projeto, o $P G$ dos asfaltos é selecionado considerando a região geográfica e as temperaturas às quais estará submetido o pavimento (a partir dos registros históricos de temperaturas do ar).

A especificação Superpave para ligantes asfálticos define o grau de desempenho (PG) com base em registros de temperaturas ambiente de estações meteorológicas por um período mínimo de 20 anos. Para cada ano devem ser determinados: 
- a média das temperaturas máximas dos sete dias consecutivos mais quentes do ano (temperatura do ar);

- a temperatura mínima do dia mais frio do ano (temperatura do ar).

Para ambas séries de dados (os quais são considerados como $\mathrm{T}_{\text {MAXar }}$ e $\mathrm{T}_{\mathrm{MINar}}$ ) devem ser determinados a média e o desvio padrão. Posteriormente, são calculadas as temperaturas do pavimento. O grau de desempenho dos ligantes asfálticos varia em níveis, sendo que cada nível equivale a $6^{\circ} \mathrm{C}$, tanto em altas como em baixas temperaturas. Os asfaltos definidos no método Superpave são apresentados na Tabela 3.1 (Motta et al., 1996).

Tabela 3.1 - Intervalos para o $P G$.

\begin{tabular}{cc}
\hline $\begin{array}{c}\text { Classificação a alta } \\
\text { Temperatura }\end{array}$ & Classificação a baixa Temperatura \\
\hline PG $46-$ & $34,40,46$ \\
PG 52 - & $10,16,22,28,34,40,46$ \\
PG $58-$ & $16,22,28,34,40$ \\
PG 64 - & $10,16,22,28,34,40$ \\
PG $70-$ & $10,16,22,28,34,40$ \\
PG $76-$ & $10,16,22,28,34$ \\
PG $82-$ & $10,16,22,28,34$ \\
\hline
\end{tabular}

Fonte: Motta et al. (1996)

\subsubsection{Temperaturas do ar $\left(T_{X X a r}\right.$ e $\left.T_{Y Y a r}\right)$}

O cálculo das temperaturas máxima e mínima do ar é realizado através das equações 3.1 e 3.2 que depende da confiabilidade requerida (z) e do desvio padrão dos dados $(\sigma)$ :

$T_{\text {MAXar }}=T_{\text {média }}+Z \times \sigma$ 
$T_{\text {MINar }}=T_{\text {média }}-Z \times \sigma$

onde:

$\mathrm{T}_{\text {MAXar }}=$ Média das temperaturas máximas do ar em 7 dias consecutivos $\left({ }^{\circ} \mathrm{C}\right)$;

$\mathrm{T}_{\text {MINar }}=$ Temperatura mínima do ar $\left({ }^{\circ} \mathrm{C}\right)$.

\subsubsection{Temperaturas do Pavimento ( $T_{\text {MAX }}$ e $\left.T_{\text {MIN }}\right)$}

As temperaturas máxima e mínima do pavimento são calculadas a partir das temperaturas do ar e de um coeficiente (Lat), dado pela localização geográfica (latitude). A temperatura do pavimento pode ser calculada através de modelos do SHRP e do LTPP Bind, os quais com o decorrer dos anos e o desenvolvimento de pesquisas contínuas foram melhorados continuamente em busca de exatidão e precisão.

O primeiro modelo desenvolvido pelo SHRP original para o cálculo das temperaturas máximas do pavimento a $20 \mathrm{~mm}$. de profundidade propôs a equação 3.3 (MC GENNIS et al., 1994):

$T_{\text {MAX }}=0,9545 \times\left(T_{\text {MAXar }}-0,00618 \times L^{2} t^{2}+0,2289 \times L a t+42.2\right)-17,78$

onde:

$\mathrm{T}_{\mathrm{MAX}}=$ Temperatura máxima do pavimento a $20 \mathrm{~mm}$ de profundidade $\left({ }^{\circ} \mathrm{C}\right)$.

$\mathrm{T}_{\text {MAXar }}=$ Média das temperaturas máximas do ar de 7 dias consecutivos $\left({ }^{\circ} \mathrm{C}\right)$.

Lat $\quad=$ Latitude de projeto $\left(^{\circ}\right)$. 
Para o cálculo das temperaturas mínimas o SHRP original recomenda considerar a temperatura do pavimento igual à temperatura mínima do ar (equação 3.4), que é uma recomendação bastante conservadora, porque geralmente a temperatura do pavimento é superior à temperatura do ar.

$T_{\text {MIN }}=T_{\text {MINar }}$

onde:

$\mathrm{T}_{\mathrm{MIN}}=$ Temperatura mínima do pavimento $\left({ }^{\circ} \mathrm{C}\right)$.

$\mathrm{T}_{\text {MINar }}=$ Temperatura mínima do $\operatorname{ar}\left({ }^{\circ} \mathrm{C}\right)$.

Os pesquisadores canadenses do C-SHRP recomendam utilizar a equação 3.5 (Motta et al., 1996).

$T_{\text {MIN }}=0,859 \times T_{M I N a r}+1,7$

onde:

$\mathrm{T}_{\mathrm{MIN}}=$ Temperatura mínima do pavimento $\left({ }^{\circ} \mathrm{C}\right)$.

$\mathrm{T}_{\text {MINar }}=$ Temperatura mínima do ar $\left({ }^{\circ} \mathrm{C}\right)$.

Posteriormente, um programa de monitorização de temperatura do ar versus temperatura de pavimento, por meio de estudos de desempenho de 30 trechos, realizado durante dois anos, dentro da continuidade da pesquisa SHRP, denominado LTPP (Long Term Pavement Performance), mostrou a necessidade de se rever os critérios anteriores de cálculo, tanto para a temperatura máxima quanto para a mínima. Verificou-se que as temperaturas mínimas do 
pavimento eram cerca de $13{ }^{\circ} \mathrm{C}$ acima da temperatura mínima do ar, mostrando assim que o modelo proposto pelo SHRP original e o desenvolvido pelo C-SHRP eram muito conservadores. Por outro lado, a Equação 3.3 estimava corretamente as temperaturas máximas do pavimento quando a temperatura do ar era inferior a $35{ }^{\circ} \mathrm{C}$, sendo que acima de $35{ }^{\circ} \mathrm{C}$ a Equação 3.3 fornecia resultados superiores às temperaturas medidas no pavimento em até $6{ }^{\circ} \mathrm{C}$. Tendo em vista a severidade do problema, foram propostas, em 1996, as Equações 3.6 e 3.7, levando em conta a latitude, a temperatura do ar e a profundidade $(\mathrm{H})$, expressa em centímetros até a superfície do pavimento (MOHSENI, 1996).

$T_{\text {MAX }}=54,32+\left[0,77585 T_{\text {MAXar }}\right]-\left[0,002468\right.$ Lat $\left.^{2}\right]-\left[15,137 \log _{10}(H+25)\right]$

onde:

$\mathrm{T}_{\mathrm{MAX}}=$ Temperatura máxima do pavimento $\left({ }^{\circ} \mathrm{C}\right)$

$\mathrm{T}_{\text {MAXar }}=$ Média da temperatura maxíma do ar $\left({ }^{\circ} \mathrm{C}\right)$

Lat $\quad=$ Latitude $\left(^{\circ}\right)$

$\mathrm{H} \quad=$ Profundidade do pavimento $(\mathrm{cm})$

$T_{M I N}=-1,56+\left[0,71819 T_{\text {MINar }}\right]-\left\lfloor 0,003966\right.$ Lat $\left.^{2}\right\rfloor+\left[6,264 \log _{10}(H+25)\right]$

onde:

$\mathrm{T}_{\mathrm{MIN}}=$ Temperatura mínima do pavimento $\left({ }^{\circ} \mathrm{C}\right)$

$\mathrm{T}_{\text {MINar }}=$ Média da temperatura mínima do $\operatorname{ar}\left({ }^{\circ} \mathrm{C}\right)$

Lat $\quad=$ Latitude $\left(^{\circ}\right)$

$\mathrm{H} \quad=$ Profundidade do pavimento $(\mathrm{cm})$ 
Com dados coletados em 30 pistas de teste nos Estados Unidos, entre 1991 e 1995, o LTPP iniciou o programa de monitorização Sazonal SMP (Seasonal Monitoring Program). A análise dos dados resultou no LTPP Bind (LTPP-FHWA, 1998 e Bosscher, 2000), que propôs para o cálculo das temperaturas mínimas do pavimento a Equação 3.8.

$T_{\text {MIN }}=-1,56+0,72 T_{\text {MINar }}-0,004 L^{2}{ }^{2}+6,26 \log (H+25)-Z \times(4,4+0,52 \times \sigma)^{1 / 2}$

onde:

$\mathrm{T}_{\mathrm{MIN}}=$ Temperatura mínima do pavimento $\left({ }^{\circ} \mathrm{C}\right)$

$\mathrm{T}_{\text {MINar }}=$ Média da temperatura mínima do ar $\left({ }^{\circ} \mathrm{C}\right)$

Lat $\quad=$ Latitude $\left({ }^{\circ}\right)$

$\mathrm{H} \quad=$ Profundidade do pavimento $(\mathrm{cm})$

$\mathrm{Z} \quad=$ Confiabilidade

$\sigma_{a r} \quad=$ Desvio padrão da temperatura mínima do $\operatorname{ar}\left({ }^{\circ} \mathrm{C}\right)$

O LTPP Bind continuou o desenvolvimento de pesquisas sobre o cálculo das temperaturas mais altas do pavimento, até que Mohseni e Carpenter (2004) apresentaram um algoritmo melhorado para o cálculo do grau de desempenho a altas temperaturas, através de um Modelo Climático Integrado (ICM), baseado em dados de aproximadamente 8000 estações meteorológicas, com dados de temperaturas horárias, velocidade do vento e radiação solar. As temperaturas máximas diárias do ar são calculadas para as temperaturas horárias no ICM e com base nessas temperaturas e na latitude de cada estação meteorológica calcula-se a temperatura máxima do pavimento a $20 \mathrm{~mm}$ de profundidade, através da Equação 3.9:

$T_{\text {MAX }}=32,7+0,837 T_{\text {MAXar }}-0,0029 L a t^{2}+z\left(\sigma^{2}+\delta^{2}{ }_{\text {modelo }}\right)^{0,5}$ 
onde:

$\mathrm{T}_{\mathrm{MAX}}=$ Temperatura máxima do pavimento $\left({ }^{\circ} \mathrm{C}\right)$

$\mathrm{T}_{\text {MAXar }}=$ Média de 7 dias da temperatura do ar $\left({ }^{\circ} \mathrm{C}\right)$

Lat $\quad=$ Latitude $\left({ }^{\circ}\right)$

$\sigma_{\mathrm{ar}} \quad=$ Desvio padrão da média anual de 7 dias da temperatura do ar $\left({ }^{\circ} \mathrm{C}\right)$

$\delta_{\text {Modelo }}=$ Erro padrão do modelo $=2.1^{\circ} \mathrm{C}$

\subsubsection{Efeito do Tráfego: Velocidade de Carga e Tráfego Acumulado}

A seleção do ligante, proposta pelo programa $S H R P$, supõe carregamentos de caminhões a velocidades altas, de aproximadamente $90 \mathrm{~km} / \mathrm{h}$, simulado no ensaio de cisalhamento dinâmico (DSR - Dynamic Shear Rheometer). Para velocidades menores, devido ao tempo de carregamento ser maior, a rigidez da mistura diminui, por isso deve-se aumentar em um ou dois níveis o grau de desempenho requerido, pois aumentar o tempo de carregamento sobre um pavimento é equivalente a aumentar a temperatura do mesmo. Por exemplo, se para uma carga normal o grau PG 70-22 é o recomendável, deve-se utilizar o grau PG 76-22 caso as cargas sejam lentas ou um PG 82-22 se as cargas forem estacionárias.

O nível de tráfego esperado na pista também influencia a temperatura alta da classificação PG. A Tabela 3.2 mostra os ajustes requeridos para várias combinações de velocidade e de volume de tráfego (C-SHRP, 1999). 
Tabela 3.2 - Novos ajustes para a seleção de ligantes asfálticos por nível de tráfego e velocidade.

\begin{tabular}{cccc}
\hline & \multicolumn{3}{c}{ Ajuste do grau do ligante PG } \\
\cline { 2 - 4 } N Projeto & \multicolumn{3}{c}{ Velocidade do Tráfego } \\
\cline { 2 - 4 } & Parado & Lento & Normal \\
& $(\mathrm{V}<20 \mathrm{~km} / \mathrm{h})$ & $(\mathrm{V}=20 \mathrm{a} 70 \mathrm{~km} / \mathrm{h})$ & $(\mathrm{V}>70 \mathrm{~km} / \mathrm{h})$ \\
\hline$<0.3$ & - & - & - \\
$0.3 \mathrm{a}<3$ & 2 & 1 & - \\
$3 \mathrm{a}<10$ & 2 & 1 & - \\
$10 \mathrm{a}<30$ & 2 & 1 & 1 \\
$\geq 30$ & 2 & 1 & - \\
\hline
\end{tabular}

FONTE: C-SHRP (1999); SUPERPAVE 2000 - improved standars for a new millennium

\subsubsection{Seleção do grau PG por programas computacionais ${ }^{5}$}

Existem nos Estados Unidos diferentes programas que servem para selecionar o $P G$ do ligante asfáltico para cada local de trabalho, entre eles o SHRP Bind, LTPP Bind, AASTHO Superpave Software.

A FHWA desenvolveu o LTPP Bind e já existem muitas versões, entre elas pode-se citar o LTPP Bind 2.0, LTPP Bind 2.1, LTPP Bind 3.0 e o mais novo que é o LTPP Bind 3.1. O programa de desempenho do pavimento em longo prazo (LTPP Bind) foi desenvolvido como resultado de um estudo de 20 anos do pavimento em serviço que começou com uma série de ensaios de campo em longo prazo, monitorando mais de 2400 pavimentos de concreto asfáltico e de cimento portland em seções de pavimentos nos Estados Unidos e Canadá. Estabelecido como parte do SHRP e agora administrado pela FHWA o LTPP foi projetado em sociedade com os estados e províncias com o objetivo de ajudar na tomada de decisões

\footnotetext{
${ }^{5}$ http://www.fhwa.dot.gov/pavement/ltpp/ltppbind.cfm (Data de acesso: Maio 2006)
} 
que conduzirão a executar pavimentos de melhor desempenho e melhor relação custo beneficio.

LTPP Bind é um programa baseado no Windows, desenvolvido pelo LTPP para ajudar às agências rodoviárias a selecionar o $P G$ com melhor relação custo - beneficio para um local particular. Baseado no programa original de seleção de ligante asfáltico SHRP Bind, LTPP Bind fornece um banco de dados de temperaturas de ar altas e baixas (mínima, média, máxima, desvio padrão, e número de anos) das estações meteorológicas dos Estados Unidos e Canadá, que proporcionam para os usuários a habilidade de:

- selecionar PGs baseado nas condições locais de temperatura atual e o nível de risco designado por sua agência rodoviária;

- utilizar o modelo SHRP original ou o modelo de temperatura revisada do LTPP para determinar o $P G$ do ligante para cada local;

- ajustar a seleção do $P G$ para diferentes níveis de tráfego, carregamento e velocidade.

\subsection{DAdOS E CONSIDERAÇÕES PARA A SELEÇÃo DO PG DO LIGANTE ASFÁLTICO}

Para a seleção do PG do ligante asfáltico a ser produzido, fez-se uso de dados de 120 estações meteorológicas, que operaram pelo menos nos últimos 25 anos. Os dados foram fornecidos pelo Senamhi-Perú ${ }^{6}$ ao departamento de controle de qualidade da direção geral de rodovias do Ministério dos Transportes, Comunicações Vivenda e Construção do Peru. Na base de dados

\footnotetext{
${ }^{6}$ Servicio Nacional de Meteorología e Hidrologia - Perú
} 
não constam os departamentos de "Ucayali" e "Madre de Dios", pois as estações meteorológicas dessas regiões encontram-se inoperantes.

\subsubsection{Metodologia de cálculo do Grau de desempenho do ligante asfáltico (PG)}

Baseado nestes dados meteorológicos primeiramente foram calculados as temperaturas máximas e mínimas do ar e posteriormente foram realizados os cálculos das temperaturas máximas e mínimas do pavimento, considerando-se um nível de confiança de $98 \%$.

O cálculo das temperaturas máximas a $20 \mathrm{~mm}$ de profundidade do pavimento foi feito por três modelos. O recomendado pelo SHRP original e dois modelos atualizados, desenvolvidos pelo Long-Term Pavement Performance (LTPP Bind) - FHWA em 1996 e 2004. Desses três, o modelo mais atualizado fornece os valores mais críticos, pois é baseado em parâmetros de temperaturas máximas horárias e tempos de duração das mesmas.

O cálculo das temperaturas mínimas do pavimento foi feito com quatro modelos diferentes. $\mathrm{O}$ recomendado pelo SHRP original, o desenvolvido pelo C-SHRP e os modelos de 1996 e 1998, desenvolvidos pelo LTPP Bind. Desses quatro, o modelo do SHRP original fornece os valores de temperaturas mínimas mais críticas.

Procedeu-se a determinação do PG do ligante asfáltico para todas as regiões do Peru, com exceção dos departamentos de "Madre de Dios" e "Ucayali", localizados na fronteira com a Amazônia brasileira (Figura 3.1) a partir das condições climáticas de cada região do Peru, destacando-se que não são considerados o volume e a velocidade de tráfego, por serem essas condições variáveis para cada região. 


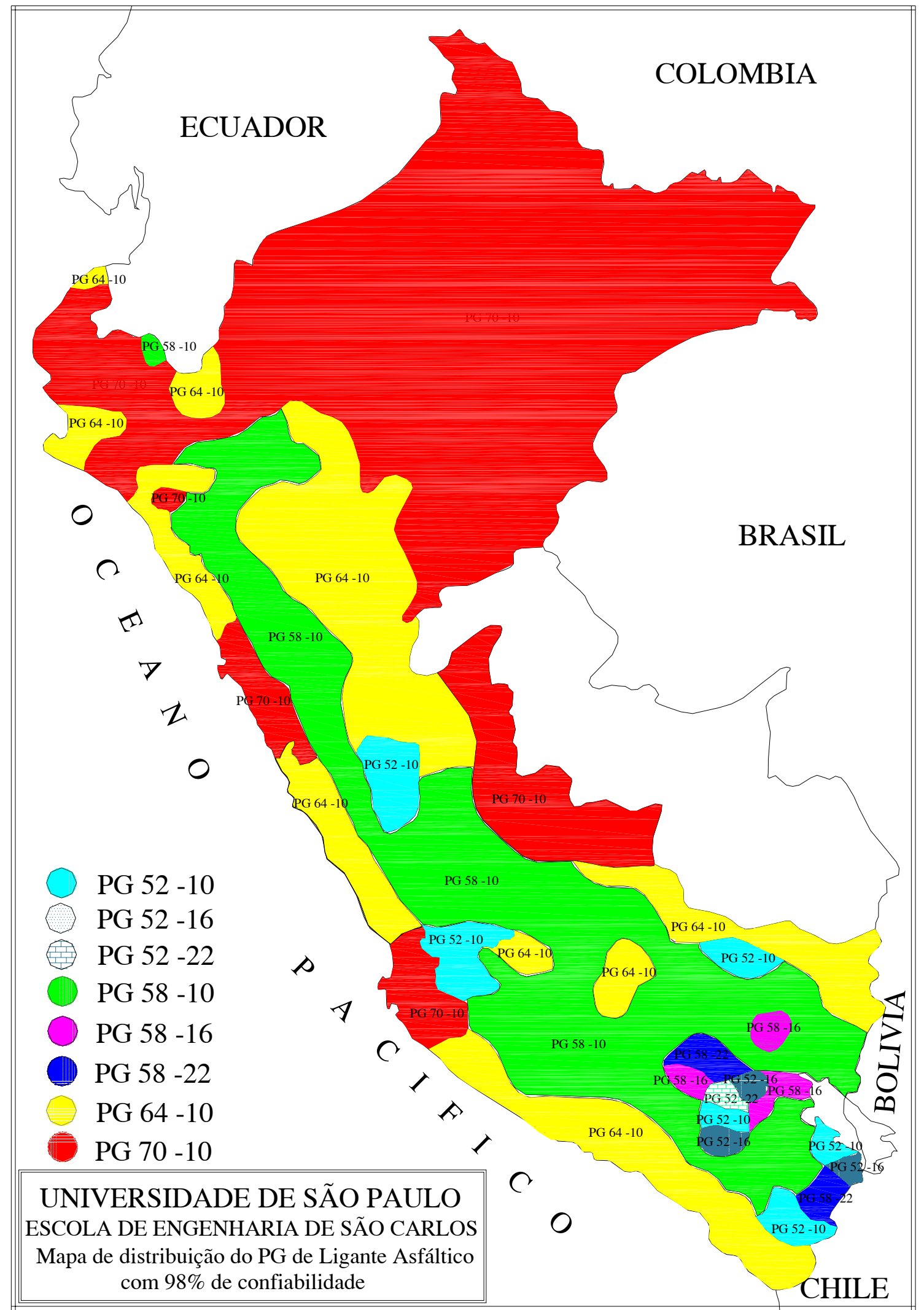

Figura 3.1 - Mapa da distribuição do PG do ligante asfáltico, sem considerar condições de tráfego. 


\subsubsection{Seleção do PG do ligante asfáltico a ser produzido}

Para a seleção do ligante asfáltico consideraram-se as condições climáticas das regiões naturais do Peru. O país apresenta 28 tipos de clima, dos 32 estabelecidos por Thornthwaite, constituindo-se num país megaclimático. As temperaturas máximas calculadas foram registradas na estação meteorológica de Junin - Satipo - Satipo, e as mínimas na estação meteorológica de Puno - Chucuito - Mazocruz, concluindo-se que para atender todas as condições climáticas do Peru, o ligante asfáltico deve ter um PG 70 -22.

Segundo Brown e Cooley (1999), a tendência é usar um ligante asfáltico convencional ou modificado com grau de desempenho (PG) um ou dois graus acima do que o recomendado para a região. Dessa forma, foram realizados os ajustes para a seleção do ligante asfáltico por nível de tráfego e velocidade, considerando-se o caso mais crítico de tráfego e uma porcentagem de tráfego lento (velocidade média de 20 a $70 \mathrm{~km} / \mathrm{h}$ ). O C-SHRP; SUPERPAVE 2000 recomenda incrementar em um nível o grau de desempenho, sendo assim o ligante asfáltico deve ter um PG 76 -22 para atender as condições climáticas e de tráfego do Peru, como é apresentado na Tabela 3.3.

Tabela 3.3 - Cálculo do PG do ligante asfáltico produzido.

\begin{tabular}{cccc}
\hline Modelo & $\begin{array}{c}\text { PG (caso mais critico) por } \\
\text { área geográfica }\end{array}$ & $\begin{array}{c}\text { Ajuste por tráfego e } \\
\text { velocidade }\end{array}$ & PG calculado \\
\hline SHRP Original & PG 64 -22 & 1 Nível & PG 70 -22 \\
SHRP Canadá & PG 64 -22 & 1 Nível & PG 70 -22 \\
LTPPBind 1996 & PG 64 -10 & 1 Nível & PG 70 -10 \\
LTPPBind 2004 & PG 70 -16 & 1 Nível & PG 76 -16 \\
\hline PG selecionado para a produção do AMP da pesquisa & PG 76 -22
\end{tabular}




\subsection{CONSIDERAÇÕES FINAIS}

O grau de desempenho PG de ligantes asfálticos do Peru foi calculado através de 4 modelos baseados nas pesquisas do SHRP e do LTPP Bind, sendo possível assim determinar o mapa de distribuição do PG do ligante asfáltico, o mesmo que servira aos orgãos rodoviários peruanos como parâmetro para a escolha do ligante asfáltico mais adeaquado para cada local de trabalho, recomendando-se que este mapa deverá ser atualizado constantemente.

Com base no grau de desempenho PG de ligantes asfálticos obtido para as condições meteorológicas e de tráfego mais críticas do estado peruano, foi produzido o AMP PG 76 -22 nos laboratórios da Betunelkoch asfaltos, o mesmo que será submetido a ensaios de avaliação de comportamento em ligante e mistura asfáltica. 


\section{CAPÍTULO IV}

\section{PROGRAMA EXPERIMENTAL}

\subsection{CONSIDERAÇÕES INICIAIS}

O programa experimental apresentado neste capítulo refere-se à determinação das propriedades dos agregados, caracterização dos ligantes asfálticos, dosagem da mistura betuminosa e determinação das propriedades mecânicas das misturas asfálticas realizadas durante o desenvolvimento da pesquisa.

\subsection{ESTUDO E CARACTERIZAÇÃO DOS MATERIAIS}

\subsubsection{Agregados Minerais}

Os agregados utilizados nesta pesquisa (pedra 1, pedrisco e pó de pedra) são de natureza basáltica, provenientes da pedreira Bandeirantes (Figura 4.1), localizada no município de São Carlos - SP. Foi escolhida essa pedreira em razão de suas semelhanças, tanto reológicas como de britagem (forma dos agregados, partículas planas e alongadas, textura superficial, etc) com do agregado peruano proveniente da pedreira "La Gloria". 


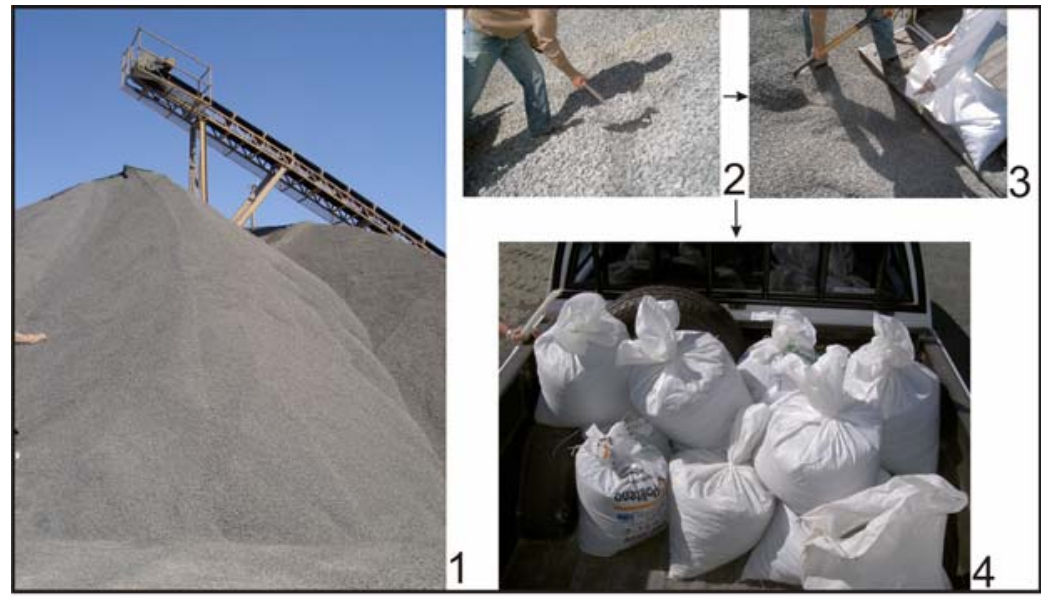

Figura 4.1 - Pedreira Bandeirantes - coleta de agregados.

\subsubsection{Ensaios para determinação das propriedades dos agregados}

Para determinação das propriedades físicas necessárias para a elaboração de misturas asfálticas foram realizados os seguintes ensaios:

- ensaio de massa específica solta e compactada (AASHTO T-19/T 19M-00/2000);

- ensaio de densidade, densidade aparente e absorção (ASTM C127 e ASTM C 128);

- ensaio de abrasão “Los Angeles” (DNER ME 035/98);

- equivalente de Areia (DNER ME 054/97);

- ensaio de análise granulométrica (DNER ME 083/98).

\section{Massa especifica solta}

A massa específica solta é a quantidade de agregados necessária para preencher um dado recipiente, sem qualquer tipo de esforço de compactação, o que representa a situação de mínimo contato entre partículas. $\mathrm{O}$ volume do recipiente a ser utilizado varia de acordo com o diâmetro máximo nominal da mistura. 
O ensaio seguiu a norma AASHTO T-19/T 19M-00 (2000). Para os agregados graúdos constituintes da mistura (Pedra 1 e pedrisco), foram utilizados um recipiente de aço de três litros, fornecido pelo laboratório de Estruturas da EESC. A massa específica solta é calculada dividindo-se o peso dos agregados que preenchem o recipiente pelo volume do recipiente.

\section{Massa especifica compactada}

A massa específica compactada, é a quantidade de agregados necessária para preencher um dado recipiente, que varia de acordo com o diâmetro máximo nominal da mistura, através de um esforço de compactação que diminui os vazios e aumenta o contato entre as partículas.

O ensaio foi realizado para a fração graúda e fina, constituintes da mistura, seguindo o indicado na norma AASHTO T-19/T 19M-00 (2000). A massa específica compactada é calculada dividindo o peso do recipiente preenchido com os agregados compactados pelo volume do recipiente. O esforço de compactação é obtido com a aplicação de 25 golpes, em cada uma das três camadas, de uma haste metálica como indica na norma.

\section{Ensaio de determinação da densidade do agregado graúdo}

O ensaio é realizado de acordo a norma americana ASTM C 127-01, cujos procedimentos consistem em (Figura 4.2):

- pesar $2 \mathrm{~kg}$ de material retido na peneira $\mathrm{N}^{\circ} 4(4,75 \mathrm{~mm})$ após lavado e seco em estufa;

- imergir a amostra seca em água por 24 horas;

- retirar o material da água e secar até a condição de saturação com secagem superficial; 
- pesar o material na condição anterior (B);

- colocar o material em uma cesta, imergir em água e determinar o peso imerso (C);

- secar o material em estufa até constância de peso e determinar o peso (A);

- calcular as densidades da seguinte maneira:

As densidades e a absorção são calculadas através das equações 4.1, 4.2, e 4.3.

$$
\begin{array}{ll}
G_{s a} \frac{A}{A-C} & \text { Densidade Real } \\
G_{s b}=\frac{A}{B-C} & \text { Densidade Aparente }
\end{array}
$$

$$
A(\%)=\left(\frac{B-A}{A}\right) \times 100 \quad \text { Absorção }
$$

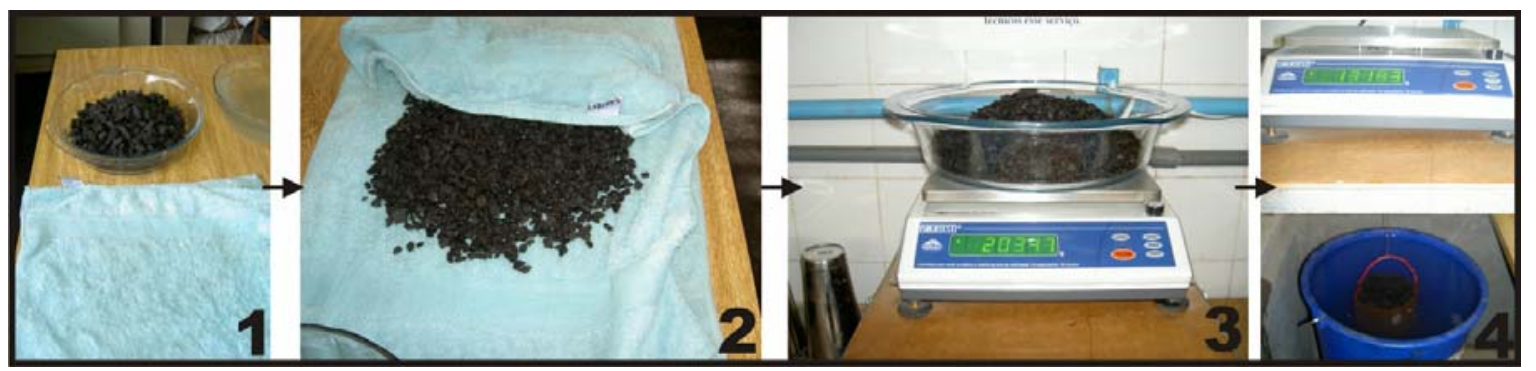

Figura 4.2 - Determinação da densidade do agregado graúdo.

\section{Ensaio de determinação da densidade do agregado miúdo}

Este ensaio foi realizado de acordo com a norma americana ASTM C 128-01, que considera como agregado miúdo aquele cujas partículas sejam menores que 4,75 mm ( $\left.\mathrm{N}^{\mathrm{o}} 4\right)$. 
Os procedimentos da determinação da densidade de agregados miúdos são (Figura 4.3):

- pesar $1000 \mathrm{~g}$ de agregado miúdo, após seco em estufa;

- imergir o material em água por 24 horas;

- espalhar o material sobre uma superfície plana submetida a uma corrente suave de ar quente;

- a condição saturada com secagem superfícial será alcançada na umidade tal que o material levemente compactado em um cone se assente quando o mesmo é removido. Este procedimento é usado até assegurar a maior umidade na qual o agregado se assente;

- $\operatorname{pesar} \pm 500 \mathrm{~g}$ do material na condição saturada superfície seca em um frasco (D);

- o frasco com material é cheio com água, usando procedimento específico, e pesado (C). Pesar também o frasco cheio com água (B);

- remover o agregado do frasco, secar em estufa até constância de peso e pesar o material (A);

- calcular as densidades da seguinte maneira:

As densidades e a absorção são calculadas através das equações 4.4, 4.5, e 4.6.

$G_{s a}=\frac{A}{B+A-C} \quad$ Densidade Real

$G_{s b}=\frac{A}{B+D-C} \quad$ Densidade Aparente

$A(\%)=\left(\frac{B-A}{A}\right) \times 100 \quad$ Absorção 


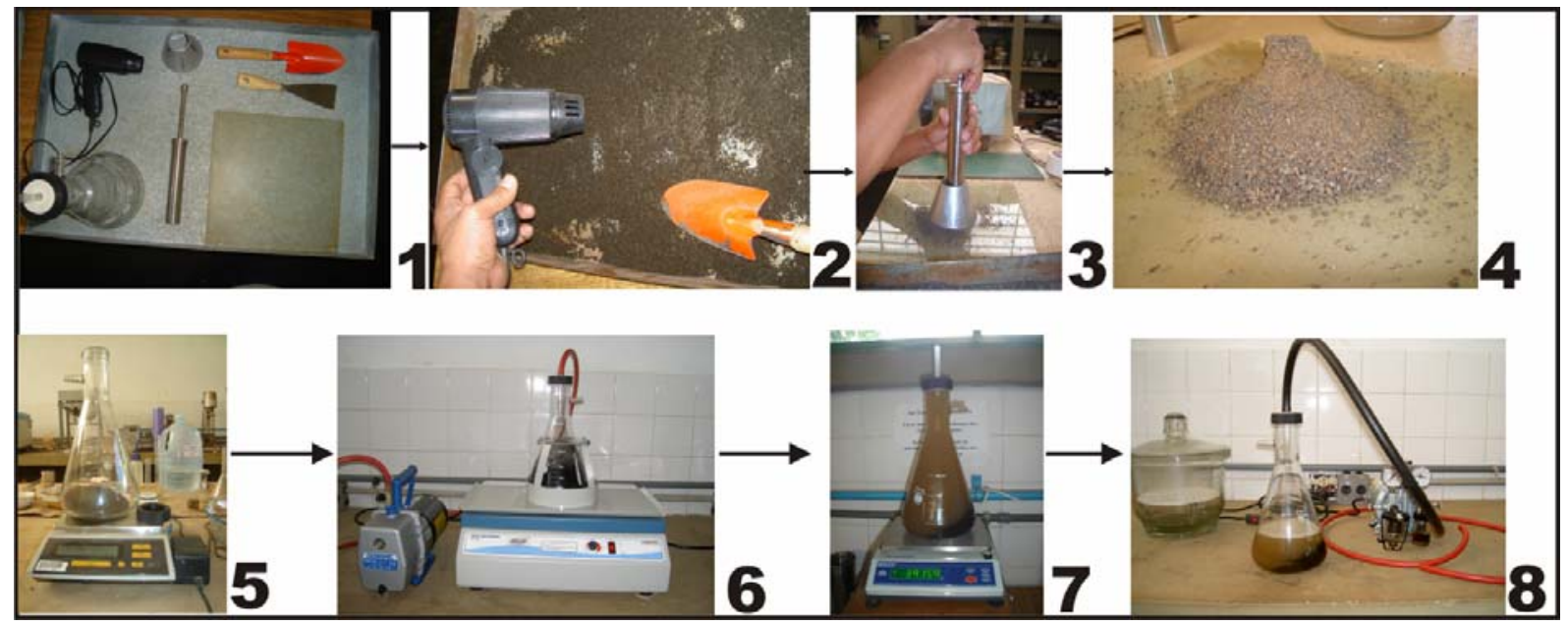

Figura 4.3 - Determinação da densidade do agregado miúdo.

\section{Ensaio de abrasão "Los Angeles"}

O ensaio de abrasão "Los Angeles" mede o desgaste de um agregado por abrasão, procurando reproduzir o impacto na amostra através da queda de esferas de aço sobre os agregados e da queda dos próprios agregados, uns sobre os outros. Simula o desgaste por meio do atrito dos agregados entre si e com as paredes do tambor enquanto gira. A amostra de agregados graúdos e as esferas de aço são colocadas no tambor da maquina "Los Angeles" (Figura 4.4). O tambor gira a velocidade de 30 a 33 rpm, até completar-se o número de revoluções especificadas. Então o material é retirado do tambor, peneirado e pesado, o resultado do ensaio é a porcentagem de perda, ou seja, a porcentagem em peso do material grosso perdido durante o ensaio, resultado da degradação mecânica. No Brasil a especificação de serviço DNER ES 313/97 aceita um valor limite de 40\%.

O ensaio foi realizado de acordo a norma DNER-ME 035/98, tomando em consideração a graduação da amostra em função da sua granulometria. A execução deste ensaio exige as seguintes operações: 
- o material recebido é lavado e seco em estufa, à temperatura entre $105^{\circ} \mathrm{C}$ e $110^{\circ} \mathrm{C}$, até se verificar constância de peso;

- depois de seco, peneira-se o agregado e quarteiam-se as diferentes porções retiradas nas diferentes peneiras, para fornecer a amostra da graduação escolhida;

- determinam-se as massas das porções de graduação escolhida, com aproximação de $1 \mathrm{~g}$, e tendo em vista a obtenção das massas especificadas na norma, obedecendo-se às respectivas tolerâncias. Reúnem-se, a seguir, as diversas porções da mesma graduação, misturam-se bem e somam-se as massas parciais correspondentes, obtendo-se, assim, a massa da amostra seca, antes do ensaio $\left(\mathrm{m}_{\mathrm{n}}\right)$;

- verificada a limpeza do tambor, colocam-se no mesmo a amostra e a respectiva carga abrasiva; o tambor é cuidadosamente fechado para evitar perda de material;

- faz-se girar o tambor com velocidade de 30 a 33 rpm, até completar 500 rotações, para as graduações A, B, C e D e 1000 rotações para as graduações E, F e G, conforme tabela da norma;

- retira-se todo o material do tambor, separam-se as esferas, limpam-se as mesmas com a escova, e faz-se passar a amostra na peneira $1,7 \mathrm{~mm}$, rejeitando-se o material passante;

- lava-se o material retido na própria peneira $1,7 \mathrm{~mm}$; reúne-se o mesmo e, em seguida, seca-se em estufa à temperatura entre $105^{\circ} \mathrm{C}$ e $110^{\circ} \mathrm{C}$, durante no mínimo 3 horas;

- retira-se o material da estufa, deixa-se esfriar, e determina-se sua massa com aproximação de 1g, obtendo-se a massa da amostra lavada e seca (m'n);

A Abrasão “Los Angeles” é calculada pela fórmula expressa na equação 4.7:

$$
A_{n}=\left(\frac{m_{n}-m_{n}^{\prime}}{m_{n}}\right) \times 100
$$


onde:

$\mathrm{A}_{\mathrm{n}}$ = Abrasão "Los Angeles" da graduação n, com aproximação de 1\%.

$\mathrm{n}=$ Graduação (A, B, C, D, E, F ou G) escolhida para o ensaio.

$\mathrm{m}_{\mathrm{n}} \quad=$ Massa total da amostra seca colocada na máquina.

$\mathrm{m}_{\mathrm{n}}=$ Massa da amostra lavada e seca, após do ensaio (retida na peneira de $1,7 \mathrm{~mm}$ ).

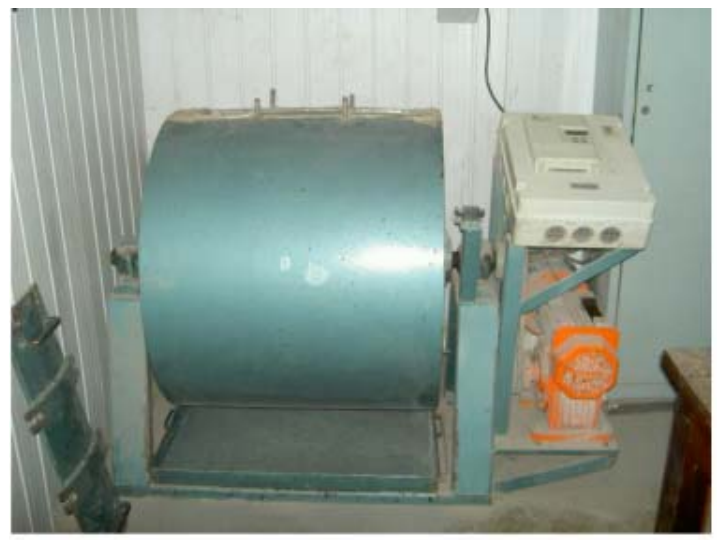

Figura 4.4 - Máquina de abrasão "Los Angeles”.

\section{Análise Granulométrica}

A granulometria do agregado é a distribuição do tamanho das partículas, expressa em porcentagem de peso ou do volume total, sendo prática padrão expressá-la como uma porcentagem do peso total.

O método utilizado para determinar a granulometria pelo processo seco é dado pelas normas ASTM C 136 e DNER ME 083/98, sendo que, no caso da granulometria por peneiramento com lavagem, é dado pela norma ASTM C 117. Entre os dois métodos, a granulometria com lavagem é mais precisa, porém o método a seco é mais rápido e mais freqüentemente utilizado. 
A granulometria afeta quase todas as propriedades de uma mistura asfáltica, entre elas a estabilidade, permeabilidade, trabalhabilidade, resistência à derrapagem, resistência à fadiga e resistência à deformação permanente, portanto a granulometria é a consideração mais importante no projeto de misturas asfálticas.

O ensaio foi realizado manualmente de acordo a norma DNER-ME 083/98 e levando-se em consideração as peneiras especificadas pelo método Superpave. A análise granulométrica foi realizada para as três frações de agregados (Pedra 1, Pedrisco e Pó de Pedra). A execução do ensaio exige as seguintes operações:

- secar a amostra de ensaio em estufa $(110 \pm 5){ }^{\circ} \mathrm{C}$, esfriar à temperatura ambiente e determinar a sua massa total;

- peneirar manualmente em todas as peneiras especificadas pela metodologia Superpave, até que não mais que $1 \%$ da massa total peneirada passe durante um período de peneirada de um minuto;

- pesar as quantidades retidas do agregado em cada peneira, tomando-se em consideração que a somatória de todas as massas retidas não deve diferir em mais de $0,3 \%$ da massa inicial seca total;

- com as massas retidas obtidas, determina-se a porcentagem acumulada de material seco em cada peneira e a porcentagem de material seco passado em cada peneira, são obtidas curvas granulométricas das diferentes frações de agregados.

Nas Figuras 4.5 e 4.6 apresentam-se o procedimento da análise granulométrica, a curva granulométrica dos agregados (pedra 1, pedrisco e pó de pedra) e a curva granulométrica da mistura utilizada na pesquisa respectivamente. 


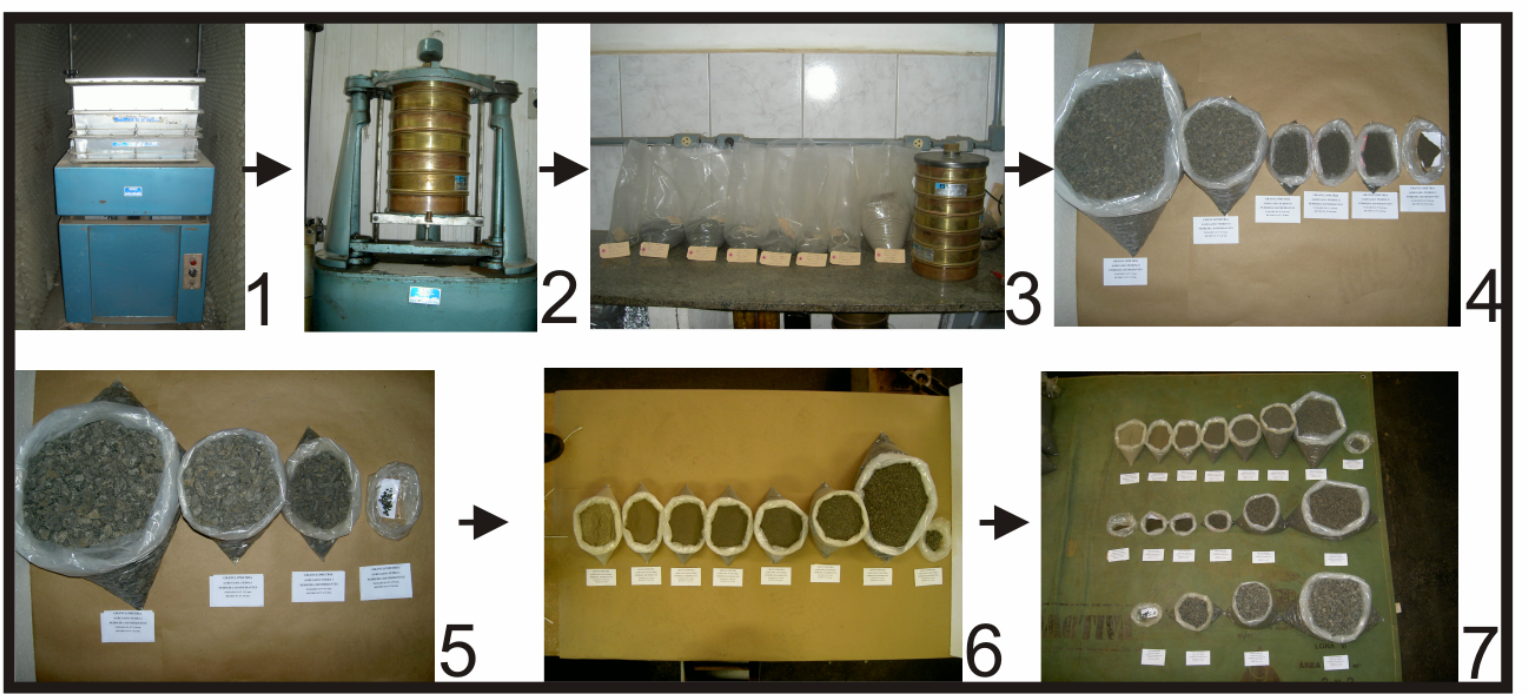

Figura 4.5 - Análise Granulométrica dos agregados utilizado na pesquisa.

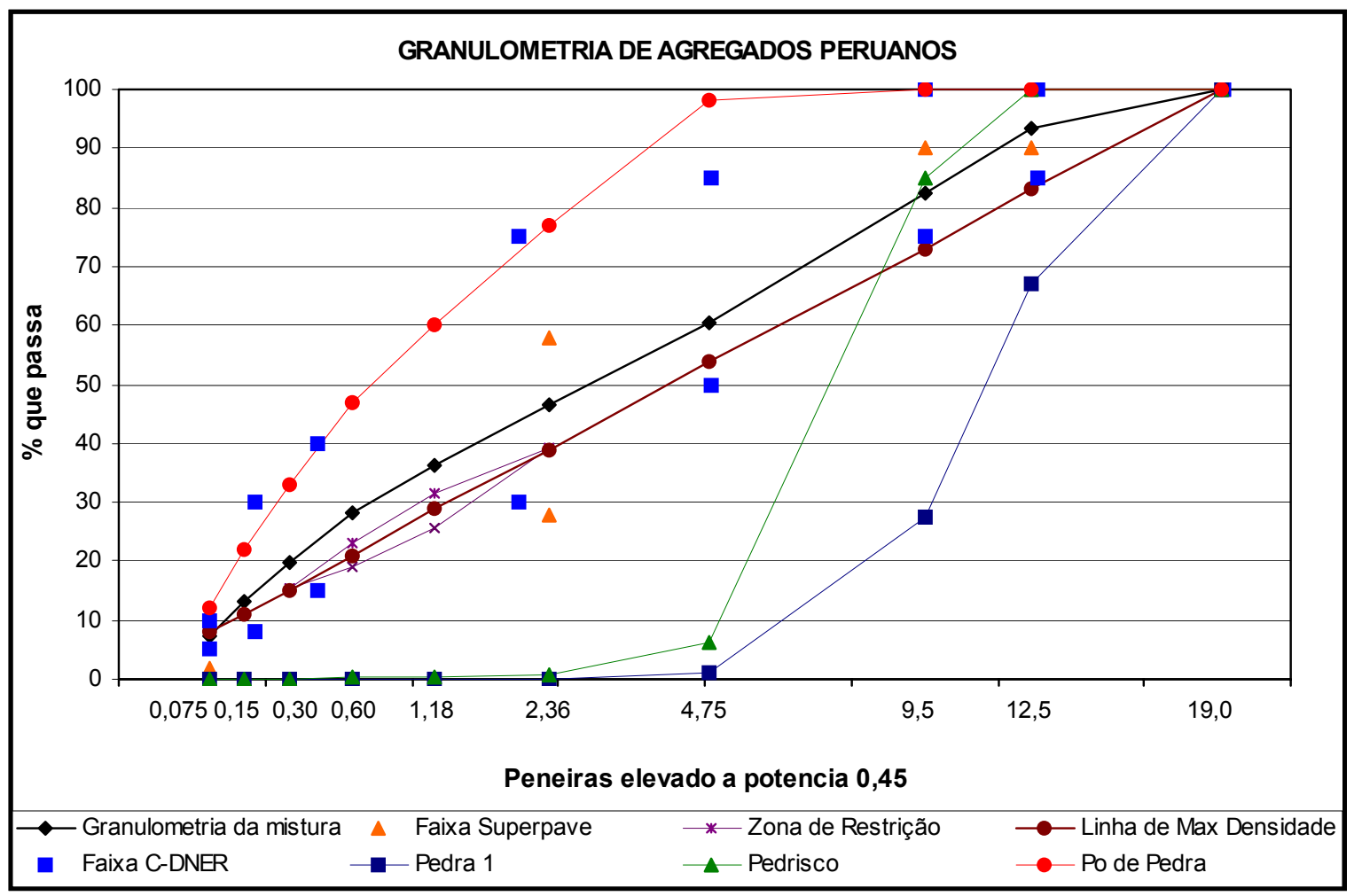

Figura 4.6 - Granulometria de agregados peruanos utilizado na pesquisa.

$\mathrm{Na}$ Tabela 4.1 apresenta-se os resultados das propriedades dos agregados peruanos, provenientes da pedreira "La Gloria", os quais foram levados em consideração para a escolha 
dos agregados para o desenvolvimento da pesquisa, já que não foi possível trazer agregados do Peru em razão da grande quantidade e do custo de transporte elevado.

Tabela 4.1 - Características dos agregados peruanos (pedreira "La Gloria").

\begin{tabular}{|c|c|c|c|}
\hline \multirow{2}{*}{ Propriedades do agregado peruano } & \multicolumn{3}{|c|}{ Agregado Mineral } \\
\hline & Pedra $N^{\circ} 1$ & Pedrisco & Pó de pedra \\
\hline Massa especifica solta $\left(\mathrm{kg} / \mathrm{m}^{\mathbf{3}}\right)$ & 1466 & 1512 &.-- \\
\hline Massa especifica compactada $\left(\mathrm{kg} / \mathrm{m}^{3}\right)$ &.-- & 1567 & 1899 \\
\hline Densidade real & 2,820 & 2,873 & 2,874 \\
\hline Densidade aparente (superfície seca) & 2,706 & 2,748 & 2,795 \\
\hline Densidade aparente (superfície saturada) & 2,746 & 2,792 & 2,823 \\
\hline Absorção (\%) & 1,49 & 1,59 & 0,97 \\
\hline Equivalente de areia $(\%)$ &.-- &.-- & 42,00 \\
\hline Abrasão (\%) & 23,5 & 25 &.-- \\
\hline Durabilidade $\mathrm{SO}_{4} \mathrm{Mg}$ & 9,35 & 9,85 & 10,12 \\
\hline \multicolumn{4}{|c|}{ Análise granulométrica } \\
\hline Abertura das peneiras & $\%$ que passa & $\%$ que passa & $\%$ que passa \\
\hline 19 & 100,00 & 100,00 & 100,00 \\
\hline 12,5 & 66,99 & 100,00 & 100,00 \\
\hline 9,5 & 27,63 & 85,06 & 100,00 \\
\hline 4,75 & 1,15 & 6,39 & 98,00 \\
\hline 2,36 & 0,00 & 0,91 & 77,00 \\
\hline 1,18 & 0,00 & 0,46 & 60,00 \\
\hline 0,6 & 0,00 & 0,27 & 47,00 \\
\hline $\mathbf{0 , 3}$ & 0,00 & 0,16 & 33,00 \\
\hline 0,15 & 0,00 & 0,08 & 22,00 \\
\hline 0,075 & 0,00 & 0,03 & 12,00 \\
\hline Pass. 0,075 & 0,00 & 0,00 & 0,00 \\
\hline
\end{tabular}

Na Tabela 4.2 apresentam-se os resultados das propriedades dos agregados brasileiros, provenientes da pedreira "Bandeirantes", os quais foram utilizados no desenvolvimento desta pesquisa. 
Tabela 4.2 - Características dos agregados brasileiros (pedreira "Bandeirantes").

\begin{tabular}{|c|c|c|c|}
\hline \multirow{2}{*}{ Propriedades do agregado brasileiro } & \multicolumn{3}{|c|}{ Agregado Mineral } \\
\hline & Pedra $N^{\circ} 1$ & Pedrisco & Pó de pedra \\
\hline Massa especifica solta $\left(\mathrm{kg} / \mathrm{m}^{3}\right)$ & 1507 & 1524 &.-- \\
\hline Massa especifica compactada $\left(\mathrm{kg} / \mathrm{m}^{3}\right)$ &.-- & 1531 & 1994 \\
\hline Densidade real & 2,876 & 2,883 & 2,893 \\
\hline Densidade aparente (superfície seca) & 2,767 & 2,788 & 2,839 \\
\hline Densidade aparente (superfície saturada) & 2,805 & 2,821 & 2,857 \\
\hline Absorção (\%) & 1,37 & 1,18 & 0,66 \\
\hline Equivalente de areia (\%) &.-- &.-- & 87,00 \\
\hline Abrasão (\%) & 21 & 23 &.-- \\
\hline Durabilidade $\mathrm{SO}_{4} \mathrm{Mg}$ & 9,05 & 9,55 & 9,85 \\
\hline \multicolumn{4}{|c|}{ Análise granulométrica } \\
\hline Abertura das penetras & $\%$ que passa & $\%$ que passa & $\%$ que passa \\
\hline 19 & 100,00 & 100,00 & 100,00 \\
\hline 12,5 & 33,09 & 100,00 & 100,00 \\
\hline 9,5 & 4,46 & 100,00 & 100,00 \\
\hline 4,75 & 0,01 & 29,74 & 99,66 \\
\hline 2,36 & 0,00 & 2,89 & 61,70 \\
\hline 1,18 & 0,00 & 1,80 & 39,21 \\
\hline 0,6 & 0,00 & 0,97 & 27,13 \\
\hline 0,3 & 0,00 & 0,05 & 19,49 \\
\hline 0,15 & 0,00 & 0,00 & 13,50 \\
\hline 0,075 & 0,00 & 0,00 & 8,55 \\
\hline Pass. 0,075 & 0,00 & 0,00 & 0,00 \\
\hline
\end{tabular}

\subsubsection{Ligantes Asfálticos}

Na presente pesquisa foram utilizados três tipos de ligante asfáltico:

- Cimento Asfáltico de Petróleo convencional PEN 60/70, proveniente da Refinaria Conchan - Lima - Peru;

- Cimento Asfáltico de Petróleo modificado por polímero SBS (Tipo I 60/60), proveniente da empresa Tecnologia de Materiales (TDM) - Peru e; 
- Cimento Asfáltico de Petróleo modificado por polímero SBS (PG 76 -22) produzido nos laboratórios da Betunelkoch Asfaltos e Tecnologia.

A Figura 4.7 apresenta os ligantes asfálticos enviados do Peru, os mesmos que foram armazenados em canecas para a preparação dos corpos de prova.

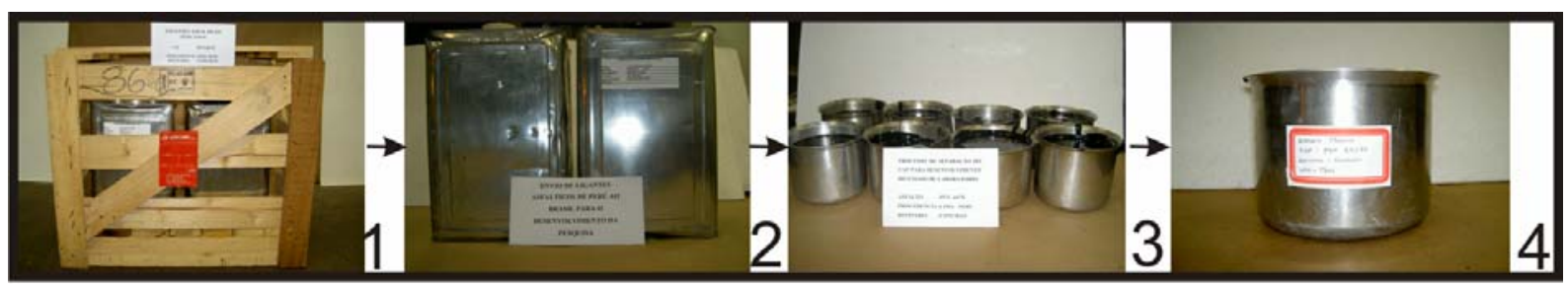

Figura 4.7 - Ligantes Asfálticos Peruanos utilizados na pesquisa.

Os dois tipos de asfalto modificado por polímero, o Tipo I 60/60 existente no mercado peruano e o PG 76 -22 produzido pela Betunelkoch Asfaltos para o desenvolvimento desta pesquisa, têm como matéria prima o Cimento Asfáltico de Petróleo PEN 60/70 da refinaria de Conchan - Lima - Peru, e o copilímero em bloco SBS. A Figura 4.8 apresenta o processo de produção de AMP SBS PG 76 -22.

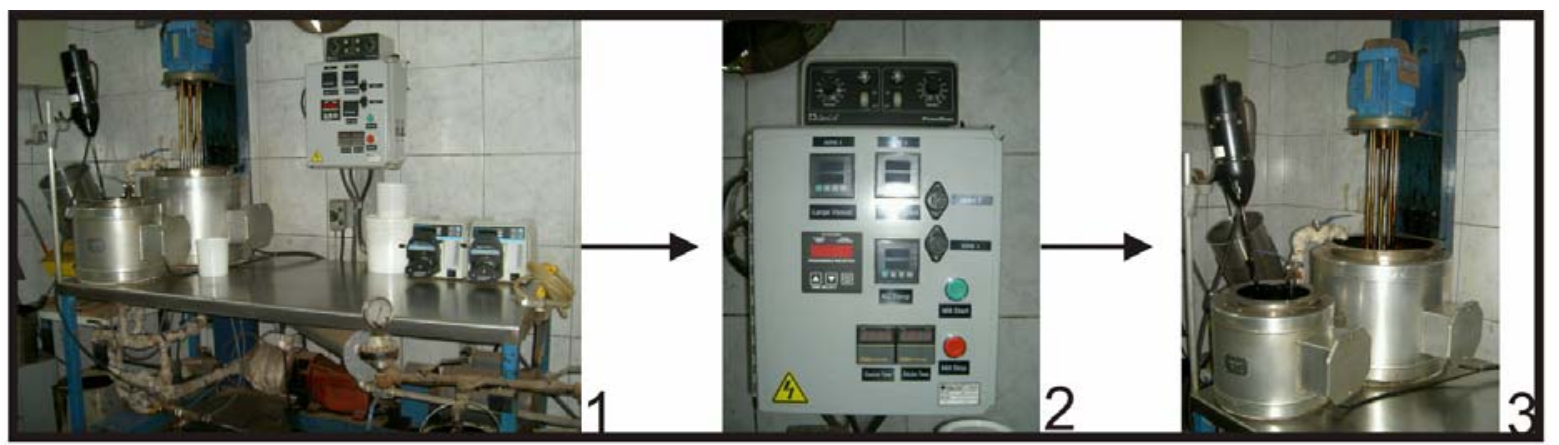

Figura 4.8 - Produção de asfalto modificado por polímero SBS PG 76 -22. 


\subsubsection{Ensaios para determinação das propriedades dos ligantes asfálticos}

Os ensaios de caracterização desenvolvidos para a determinação das propriedades dos ligantes asfálticos realizados pelo método convencional e Superpave, foram:

\section{Caracterização do ligante asfáltico pelo método convencional}

Os ensaios de caracterização especificados pelo método convencional realizados foram:

- penetração (ASTM D 5, DNER-ME 003/99);

- ponto de amolecimento (ASTM D 36, ABNT NBR 6560 / 2000);

- viscosidade Brookfield (ASTM D 4402, ABNT NBR 15184 / 2003);

- ponto de fulgor (ASTM D 92, DNER-ME 148/94);

- retorno Elástico (DNER-ME 382/99);

- efeito do calor e ar (ASTM D 2872, ABNT NBR 14736 / 2001).

\section{Penetração (ASTM D 5, DNER-ME 003/99)}

O ensaio de penetração é usado para medir a consistência do CAP. A penetração é a distância em décimos de milímetro, que uma agulha padronizada penetra verticalmente em uma amostra do material, sob condições estabelecidas de carga, tempo e temperatura, este ensaio foi realizado de acordo com a norma ASTM D 5 como é apresentado na Figura 4.9. 


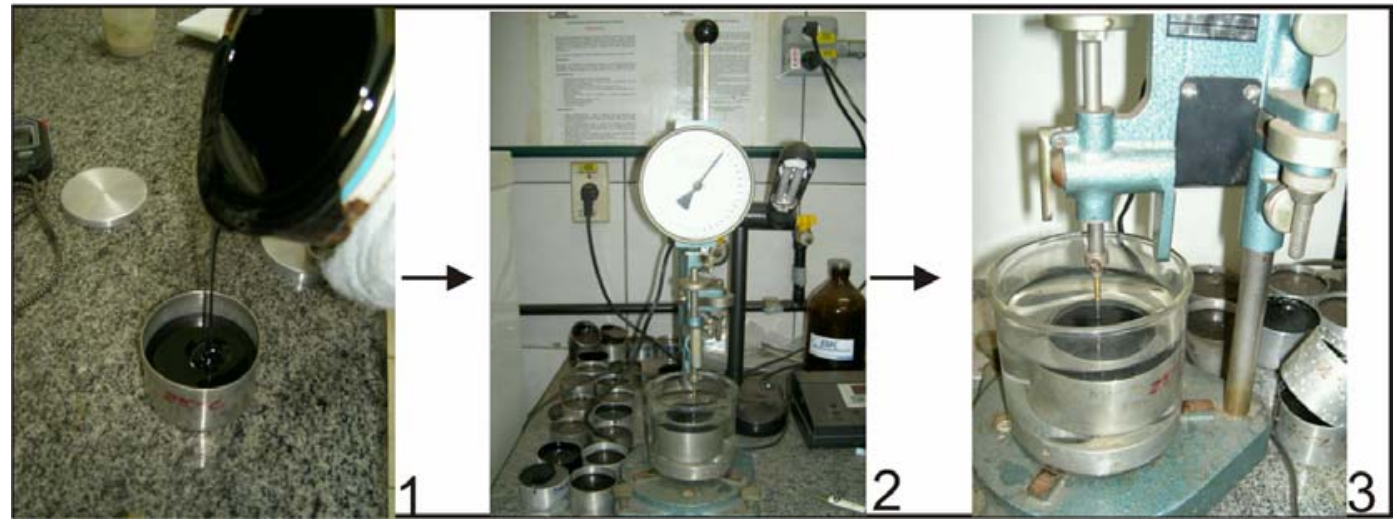

Figura 4.9 - Ensaio de Penetração.

\section{Ponto de amolecimento (ASTM D 36, ABNT NBR 6560 / 2000)}

Cimentos asfálticos são materiais viscoelásticos, sem ponto de fusão definido. Amolecem gradativamente à proporção que a temperatura aumenta. Assim, é necessário determinar o ponto de amolecimento por meio de um procedimento arbitrário, mas em condições bem definidas, para que possa ser reproduzido.

O ensaio consiste na determinação da temperatura em que uma esfera de aço atravessa um corpo-de-prova constituído de um disco de amostra contido em anel metálico, tendo a finalidade de estabelecer uma temperatura de referência similar à temperatura de fusão dos materiais, os procedimentos deste ensaio são apresentados na Figura 4.10.

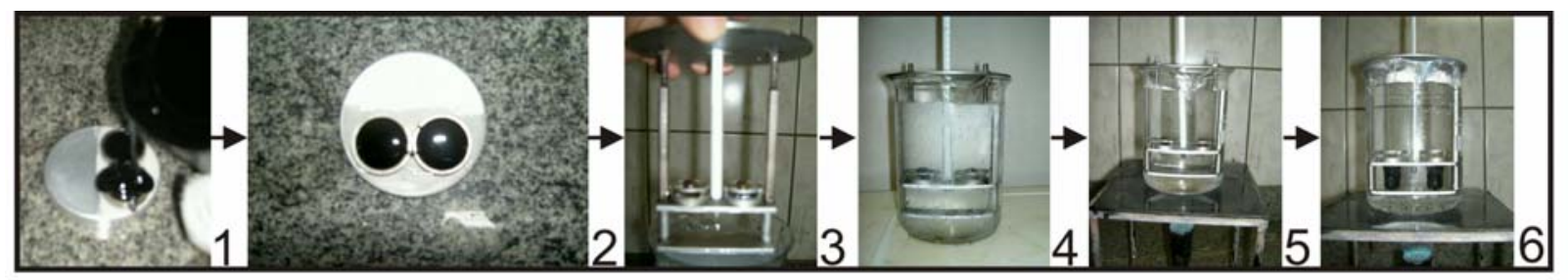

Figura 4.10 - Ensaio de Ponto de Amolecimento. 


\section{Índice de susceptibilidade térmica}

Susceptibilidade térmica é a variação da consistência do CAP com a variação da temperatura, devendo-se evitar, durante o inverno, o surgimento de trincas devidas à alta consistência em temperaturas baixas e durante o verão a deformação permanente, em razão da baixa consistência em temperatura alta.

O índice de susceptibilidade térmica correlaciona as variações de temperatura e a consistência das misturas asfálticas. Asfaltos pouco susceptíveis tornam-se duros e quebradiços, em condições de baixas temperaturas. Asfaltos muito susceptíveis modificam sua consistência para pequenas variações de temperatura. O índice mais aceito é o P.V.D. - Pfeiffer-van Doormal (SENÇO, 1997), que relaciona os índices de penetração a $25^{\circ} \mathrm{C}$ e os respectivos pontos de amolecimento, de acordo com a fórmula expressa na equação 4.8 :

Índice P.V.D $=\frac{\left[500 \times(\log P e n)+20 \times\left(T^{\circ} \mathrm{C}\right)-1951\right]}{\left[120-50 \times(\log P e n)+\left(T^{\circ} \mathrm{C}\right)\right]}$

onde:

$\begin{array}{ll}\text { Pen } & =\text { Penetração a } 25^{\circ} \mathrm{C}, 100 \mathrm{~g}, 5 \mathrm{seg} . \\ \mathrm{T}^{\circ} \mathrm{C} & =\text { Temperatura média do ponto de amolecimento do asfalto. }\end{array}$

Viscosidade Brookfield (ASTM D 4402, ABNT NBR 15184 / 2003)

O Viscosimetro Brookfield realiza a medida cientifica do escoamento do fluido a altas temperaturas. O principio de operação é medir através de uma mola calibrada o torque provocado pelo movimento rotacional de um spindle imerso no fluido para teste. Mede-se a 
viscosidade, em centi Poises, e a taxa de cisalhamento em s${ }^{-1}$, os procedimentos deste ensaio são apresentados na Figura 4.11.

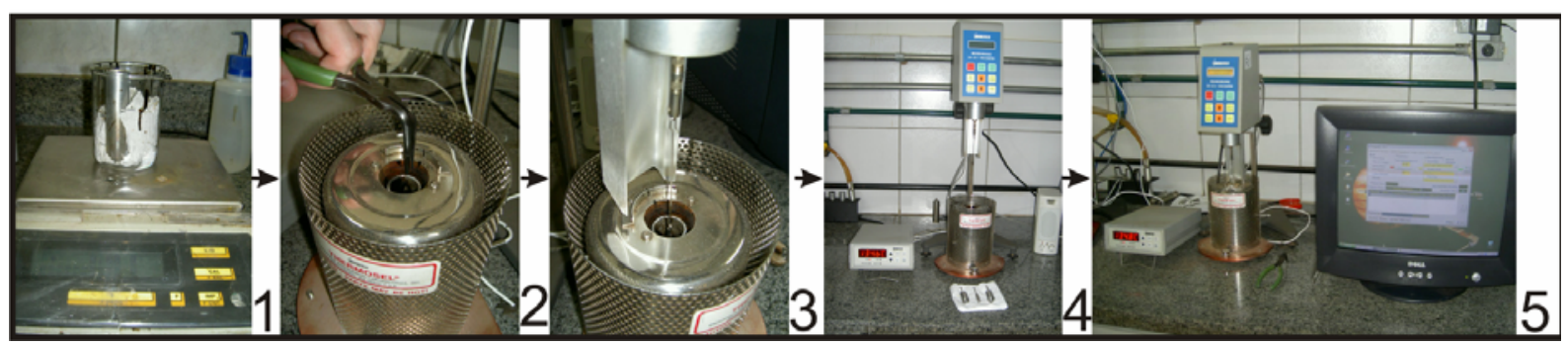

Figura 4.11 - Ensaio de Viscosidade Brookfield.

\section{Ponto de fulgor (ASTM D 92, DNER-ME 148/94)}

Ponto de fulgor é a indicação da temperatura limite em que o CAP pode ser aquecido, sem risco de inflamar-se em contato com chama, sendo o ensaio realizado seguindo a norma ASTM D 92. Consiste na determinação da temperatura para a qual uma amostra de produto asfáltico começa a liberar gases inflamáveis. O aparelho de ensaio é mostrado na Figura 4.12.

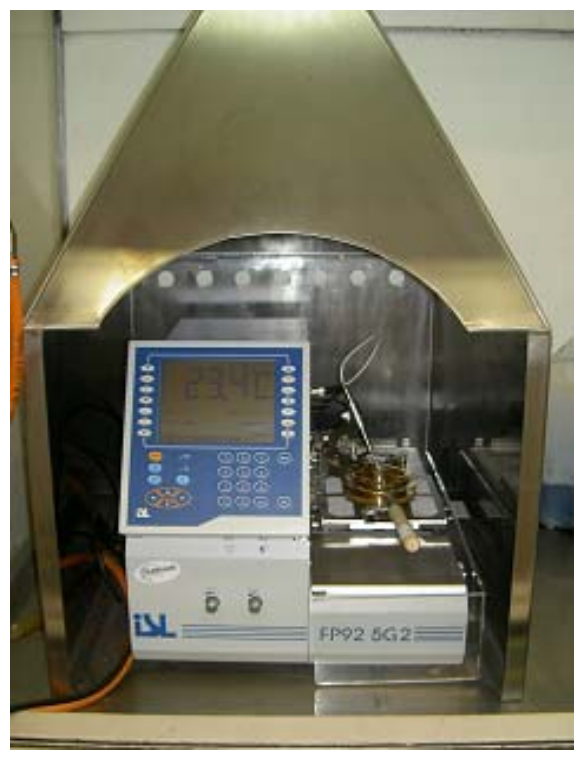

Figura 4.12 - Ensaio de Ponto de Fulgor. 


\section{Retorno Elástico (DNER-ME 382/99)}

O retorno elástico é a capacidade de retorno do sistema asfalto-polímero após interrupção de tração mecânica especificada. O objetivo é a determinação da recuperação elástica de materiais asfálticos modificados por polímeros, utilizando-se o ductilômetro mostrado na Figura 4.13.

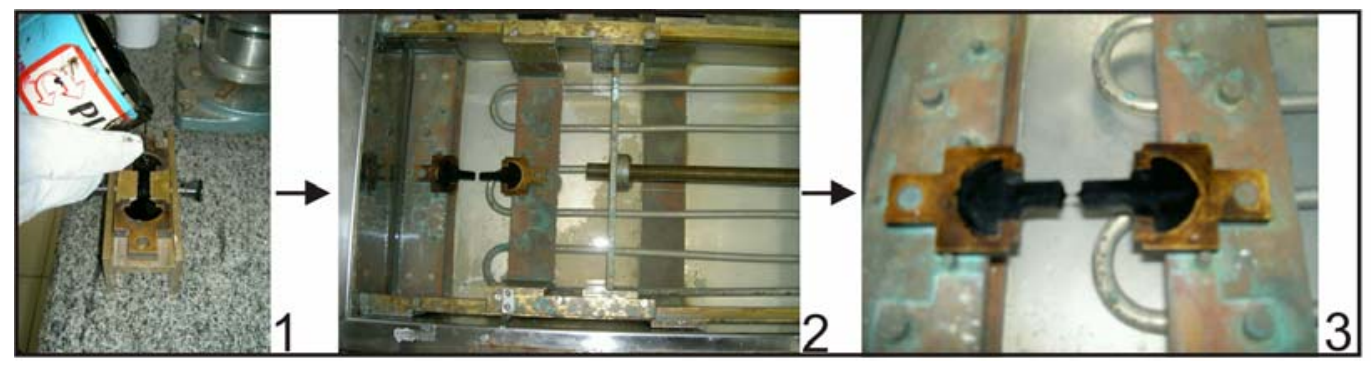

Figura 4.13 - Ensaio de Retorno Elástico.

\section{Efeito do calor e ar (ASTM D 2872, ABNT NBR 14736 / 2001)}

O ligante betuminoso não deve endurecer excessivamente durante a estocagem, o processo de usinagem e o serviço de pavimentação. Os asfaltos são afetados pela presença de oxigênio, pela radiação ultravioleta e por variações de temperatura. Essas influências externas resultam em aumento da consistência do ligante e em maior rigidez da mistura betuminosa, acarretando fissuras e desagregação. 


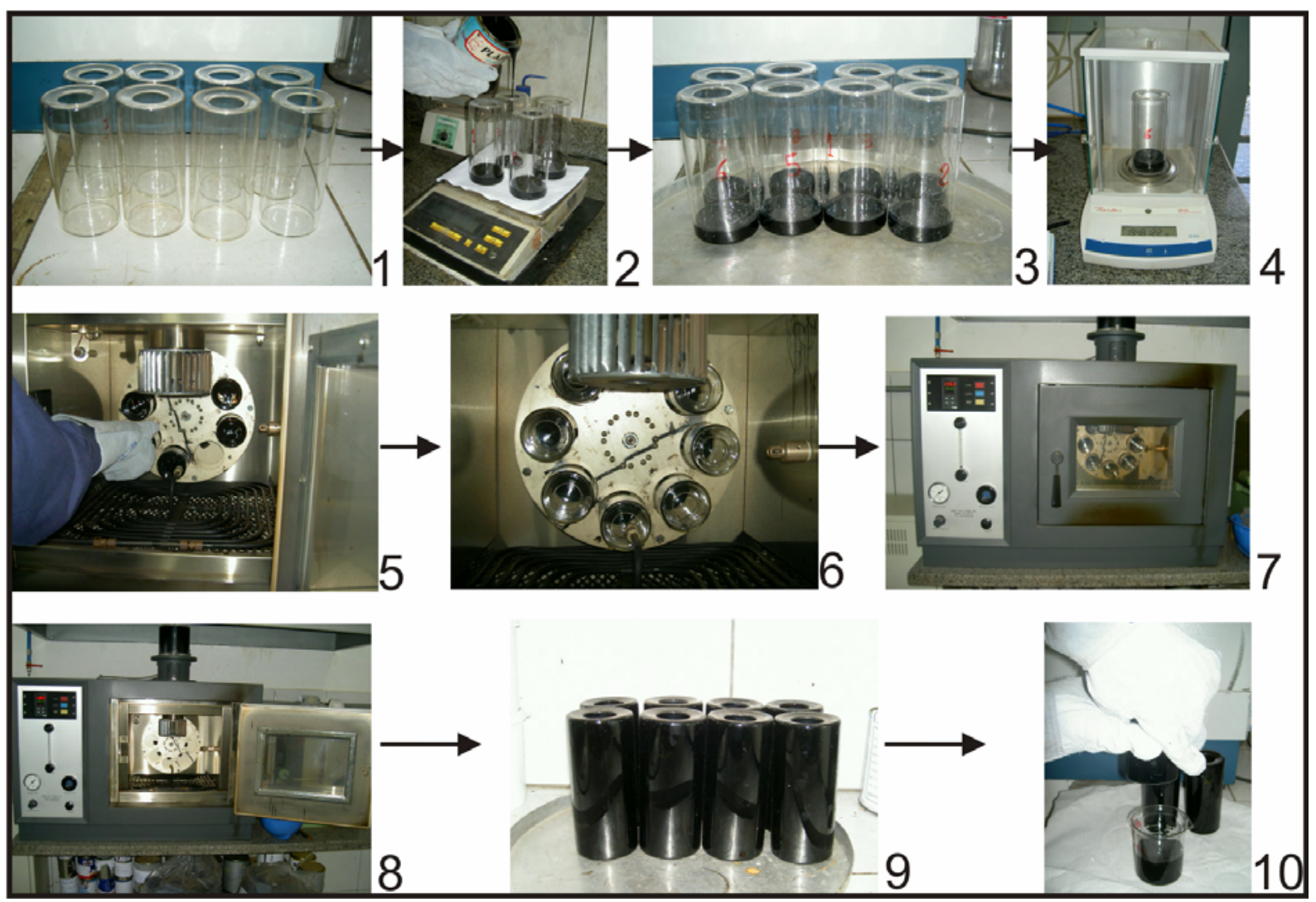

Figura 4.14 - Ensaio de efeito do calor e ar - RTFOT.

Os ensaios de caracterização dos ligantes asfálticos foram realizados no Laboratório de Desenvolvimento Tecnológico da Betunelkoch Asfaltos e Tecnologia. Os resultados dos ensaios de caracterização convencional apresentam-se na Tabela 4.3. 
Tabela 4.3 - Resultados de caracterização dos asfaltos PEN 50/70, asfalto modificado por polímero AMP Tipo I 60/60 e asfalto modificado por polímero AMP PG 76 -22

\begin{tabular}{|c|c|c|c|c|c|c|}
\hline \multirow[b]{2}{*}{ CARACTERÍSTICAS } & \multirow[b]{2}{*}{ UN. } & \multicolumn{3}{|c|}{ LIGANTE ASFÁLTICO } & \multicolumn{2}{|c|}{ MÉTODOS } \\
\hline & & $\begin{array}{l}\text { PEN } \\
60 / 70\end{array}$ & $\begin{array}{c}\text { AMP Tipo I } \\
60 / 60\end{array}$ & $\begin{array}{c}\text { AMP } \\
\text { PG } 76-22\end{array}$ & ABNT & ASTM \\
\hline Penetração $\left(100 \mathrm{~g}, 5 \mathrm{~s}, 25^{\circ} \mathrm{C}\right)$ & $0,1 \mathrm{~mm}$ & 60 & 49 & 56 & NBR 6576 & D 5 \\
\hline Ponto de amolecimento & ${ }^{\circ} \mathrm{C}$ & 51 & 66 & 68 & NBR 6560 & D 36 \\
\hline \multicolumn{7}{|l|}{ Viscosidade Brookfield } \\
\hline a $135^{\circ} \mathrm{C}$, spindle $21,20 \mathrm{rpm}$, mín & $\mathrm{cP}$ & 455 & 1383 & 1089 & NBR 15184 & D 4402 \\
\hline a $155^{\circ} \mathrm{C}$, spindle $21,20 \mathrm{rpm}$, mín & $\mathrm{cP}$ & 178 & 485 & 581 & NBR 15184 & D 4402 \\
\hline a $175^{\circ} \mathrm{C}$, spindle $21,20 \mathrm{rpm}$, mín & $\mathrm{cP}$ & 81 & 222 & 278 & NBR 15184 & D 4402 \\
\hline Índice de susceptibilidade térmica & & $-0,5$ & 2,1 & 2,8 & & \\
\hline Ponto de fulgor & ${ }^{\circ} \mathrm{C}$ & 235 & $>240$ & $>240$ & NBR 11341 & D 92 \\
\hline Retorno Elástico & $\%$ &.-- & 86 & 93 & NBR-15086 & D 6084 \\
\hline Estabilidade a Estocagem & ${ }^{\circ} \mathrm{C}$ &.-- & 0 & 0 & NBR 15166 & \\
\hline \multicolumn{7}{|c|}{ Efeito do calor e do ar (RTFOT) a $163^{\circ} \mathrm{C}, 85 \mathrm{~min}$} \\
\hline Variação em massa & $\begin{array}{c}\% \\
\text { massa }\end{array}$ & $-0,518$ & $-0,312$ & $-0,304$ & NBR-15235 & D 2872 \\
\hline \multicolumn{7}{|l|}{ Viscosidade Brookfield } \\
\hline a $135^{\circ} \mathrm{C}, \mathrm{SP} 21,20 \mathrm{rpm}$, mín & $\mathrm{cP}$ & 949 & 2535 & 1943 & NBR 15184 & D 4402 \\
\hline a $155^{\circ} \mathrm{C}, \mathrm{SP} 21,20 \mathrm{rpm}$, mín & $\mathrm{cP}$ & 319 & 774 & 898 & NBR 15184 & D 4402 \\
\hline a $175^{\circ} \mathrm{C}, \mathrm{SP} 21,20 \mathrm{rpm}$, mín & $\mathrm{cP}$ & 134 & 312 & 342 & NBR 15184 & D 4402 \\
\hline Relação de viscosidade, max & $\%$ & 2,0 & 1,7 & 1,6 & & \\
\hline Ponto de amolecimento & ${ }^{\circ} \mathrm{C}$ & 61 & 72 & 73 & NBR 6560 & D 36 \\
\hline Aumento/Diminuição do P. A. & ${ }^{\circ} \mathrm{C}$ & +10 & +6 & +5 & & \\
\hline Penetração & $0,1 \mathrm{~mm}$ & 28 & 34 & 36 & NBR 6576 & D 5 \\
\hline Índice de susceptibilidade térmica & & $-0,1$ & 2,2 & 2,5 & & \\
\hline Penetração retida & $\%$ & 47 & 69 & 64 & & \\
\hline Retorno Elástico & $\%$ &.-- & 82 & 89 & NBR-15086 & D 6084 \\
\hline Retorno Elástico retido & $\%$ &.-- & 95 & 96 & & \\
\hline
\end{tabular}

\section{Caracterização do ligante asfáltico pelo método Superpave}

Os ensaios adicionais realizados para caracterizar os ligantes asfálticos pela especificação Superpave foram: 
- cisalhamento dinâmico $-\mathrm{G}^{*} / \operatorname{sen} \delta \geq 1 \mathrm{KPa},\left({ }^{\circ} \mathrm{C}\right)$ - DSR, (AASHTO T 315-02 ).

Após envelhecimento no RTFOT

- perda em massa \% - RTFOT (ASTM D 2872);

- cisalhamento dinâmico - $\mathrm{G}^{*} / \mathrm{sen} \delta \geq 2,2 \mathrm{KPa},\left({ }^{\circ} \mathrm{C}\right.$ ) - DSR (AASHTO T 315-02).

Após envelhecimento no RTFOT/PAV (ASTM D 454, ABNT NBR 15235)

- cisalhamento dinâmico - $\mathrm{G}^{*} \operatorname{sen} \delta \leq 5000 \mathrm{KPa},\left({ }^{\circ} \mathrm{C}\right)$ - DSR (AASHTO T 315-02);

- rigidez a fluência BBR - $\mathrm{S} \leq 300 \mathrm{MPa}$ e $\mathrm{m} \geq 0,3,\left({ }^{\circ} \mathrm{C}\right)$ - BBR (ASTM D 6648-01).

As propriedades físicas dos asfáltos são medidas, utilizando quatro aparelhos de ensaios:

- viscosímetro rotacional (Rotational Viscometer - RV);

- reômetro de cisalhamento dinâmico (Dynamic Shear Rheometer - DSR);

- reômetro de fluência em viga (Bending Beam Rheometer - BBR);

- prensa de tração direta (Direct tensión tester - DTT).

\section{Viscosímetro Rotacional Brookfield (Rotational Viscometer - $R V$ )}

O Viscosímetro Rotacional (ASTM D 4402) é utilizado para caracterizar a rigidez do asfalto acima de $100^{\circ} \mathrm{C}\left(135,155\right.$ e $\left.175^{\circ} \mathrm{C}\right)$, na qual age quase que inteiramente como um fluido viscoso. É um viscosímetro rotacional de cilindros coaxiais, que mede a viscosidade através do torque necessário para rodar um spindle (ponta de prova) imerso na amostra de asfalto quente, à velocidade constante de $20 \mathrm{rpm}$. A especificação de ligante requer que este tenha 
uma viscosidade inferior a 3 Pa.s $(3000 \mathrm{cP})$ a $135^{\circ} \mathrm{C}$, para assegurar que o ligante pode ser bombeado e facilmente usinado (MOTTA et al., 1996).

O Viscosímetro Rotacional (RV) é recomendado para ensaiar ligantes asfálticos modificados (ligantes com polímeros ou borracha), pois os viscosímetros capilares podem apresentar ineficiência nos ensaios desses ligantes, devido ao fato de que pode ocorrer o entupimento do aparelho utilizado e inibição do fluxo do ligante. Na Figura 4.15 é apresentado o viscosímetro rotacional RV II na qual foram feitos os ensaios de viscosidade Brookfield.

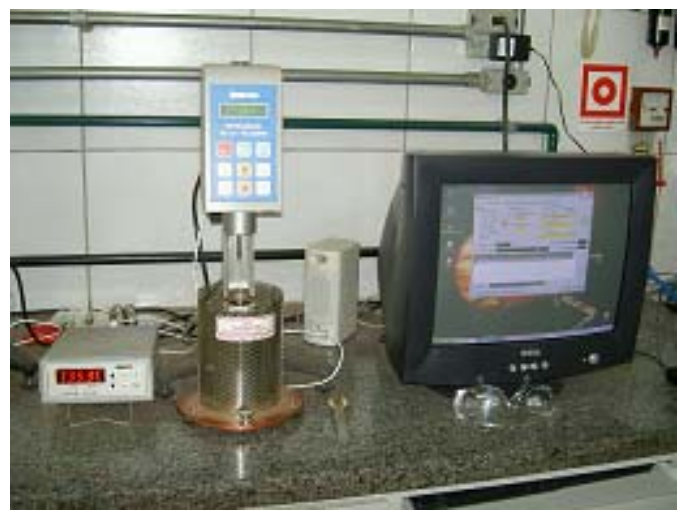

Figura 4.15 - Viscosimetro Brookfield.

\section{Reômetro de Cisalhamento Dinâmico (Dynamic Shear Rheometer - DSR)}

O DSR (AASHTO T 315-02), que é usado para caracterizar as propriedades viscoelásticas do ligante, mede o módulo viscoelástico do asfalto em um modo de carga senosoidal (oscilatório). As medidas podem ser obtidas a diferentes temperaturas, para diferentes valores de tensão-deformação e variadas freqüências.

O DSR é usado nas especificações Superpave para medir o módulo complexo de cisalhamento $\left(\mathrm{G}^{*}\right)$ e o ângulo de fase $(\delta)$ dos ligantes asfálticos em altas e médias temperaturas de serviço, a 
uma freqüência de $10 \mathrm{rad} / \mathrm{s}$, onde o módulo complexo é de aproximadamente $10 \mathrm{MPa}$ ou mais (intervalo típico de medição varia entre $1 \mathrm{~Pa}$ e $100 \mathrm{MPa}$ ).

As Figuras 4.16 e 4.17 mostram um esquema de reômetro que consta das especificações do SHRP. Apresentam, de forma esquemática, os valores de $G^{*}$ e $\delta$ medidos pelo DSR, como resposta a uma deformação cisalhante em torque constante de uma amostra. Na ilustração, a resposta à deformação cisalhante de uma amostra de ligante está "defasada" em relação à tensão aplicada por certo intervalo de tempo $\Delta \mathrm{t}$.

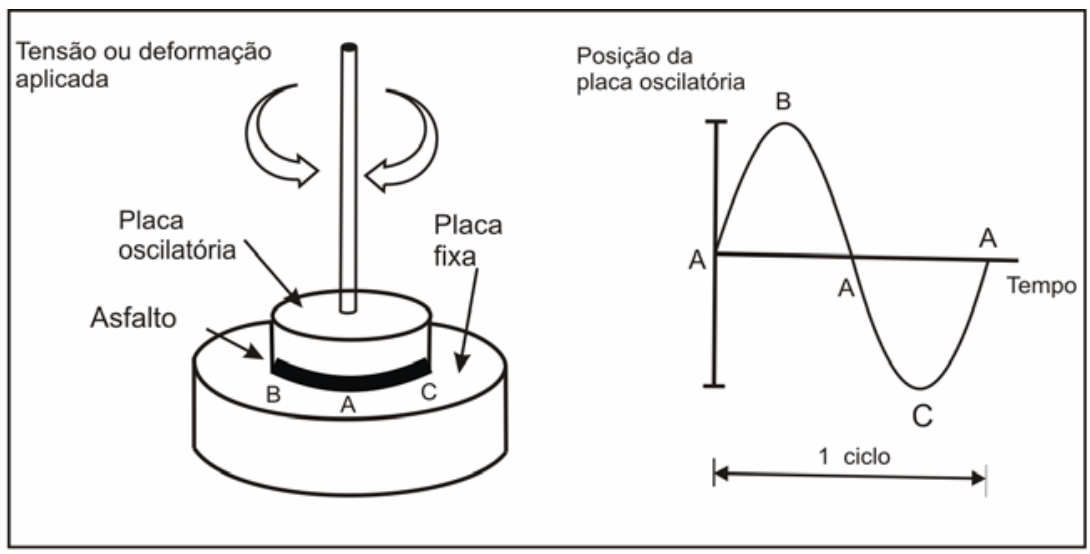

Figura 4.16 - Reômetro de Cisalhamento Dinâmico.

Fonte: Motta et al. (1996)

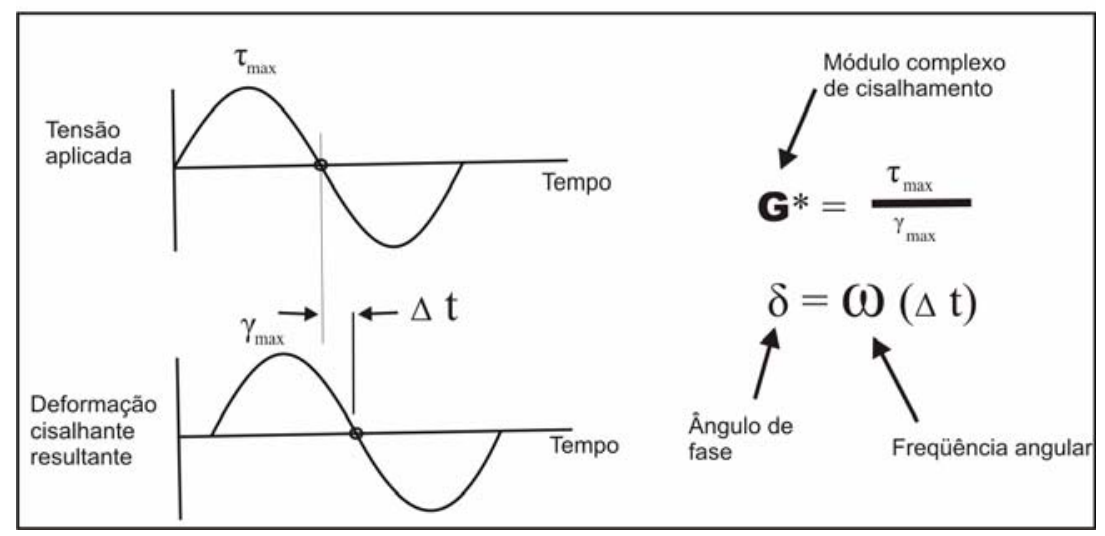

Figura 4.17 - Cálculo do módulo complexo $\mathrm{G}^{*}$ e do ângulo de fase $\delta$ medidos no DSR.

Fonte: Motta et al. (1996) 
Esse intervalo de tempo representa o atraso na deformação obtida. A fase em atraso é expressa em medida angular como o tempo de atraso $(\Delta t)$ multiplicado pela freqüência angular $(\omega)$ para atingir o ângulo de fase $(\delta)$. Para materiais completamente elásticos, não existe atraso entre a tensão cisalhante aplicada e a deformação cisalhante obtida, sendo $\delta$ igual a $0^{\circ}$. Para materiais totalmente viscosos, a deformação obtida está completamente defasada e $\delta$ vale $90^{\circ}$. Materiais viscoelásticos, tais como ligantes asfálticos, possuem ângulo de fase variando entre $0^{\circ}$ e $90^{\circ}$, dependendo da temperatura.

Em altas temperaturas, $\delta$ tende a $90^{\circ}$ e a baixas temperaturas $\delta$ tende a $0^{\circ}$. A especificação de ligante usa o parâmetro $\mathrm{G}^{*} / \operatorname{sen} \delta(=1 / \mathrm{J}$ ') $)$ para temperaturas altas $\left(>46^{\circ} \mathrm{C}\right)$ e $\mathrm{G}^{*} \operatorname{sen} \delta\left(=\mathrm{G}^{\prime \prime}\right)$ para temperaturas intermediárias (entre $7^{\circ} \mathrm{C}$ e $34^{\circ} \mathrm{C}$ ), como forma de controlar a rigidez do asfalto. A Figura 4.18 apresenta o procedimento do ensaio de cisalhamento dinâmico no DSR.

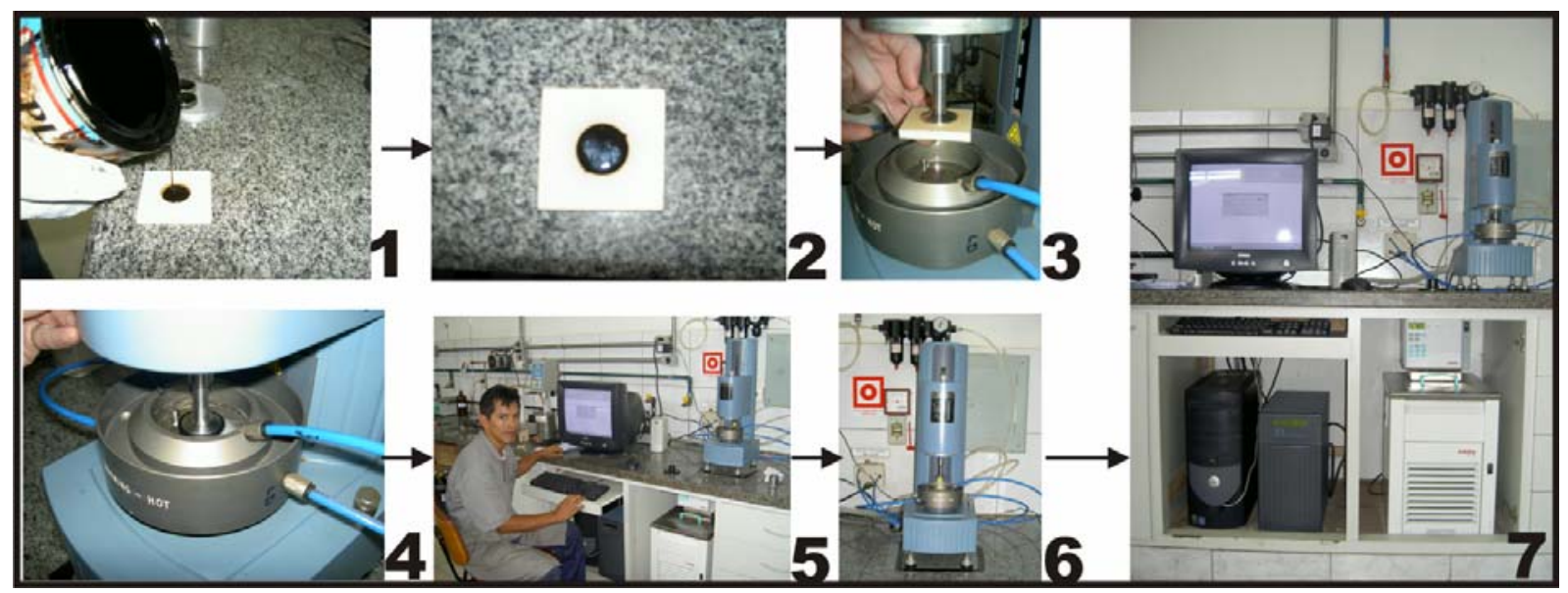

Figura 4.18 - Ensaio de módulo complexo de cisalhamento - DSR.

\section{Estufa de Filme Fino Rotativo (Rolling Thin Film Oven Test - RTFOT)}

O RTFOT (ASTM D 2872) é utilizado para simular o envelhecimento por oxidação e evaporação durante a produção e execução da mistura asfáltica. O ensaio é feito colocando-se 
uma quantidade especificada de cimento asfáltico $(35 \mathrm{~g})$ numa jarra, que gira dentro de uma estufa a $163^{\circ} \mathrm{C}$. Por intermédio de um orifício aberto na jarra, uma corrente de ar atinge a mistura a cada rotação da placa rotativa com as jarras. $\mathrm{O}$ ensaio dura aproximadamente 85 minutos. A Figura 4.19 apresenta o RTFOT em que foram feitos os ensaios de envelhecimento em curto prazo.

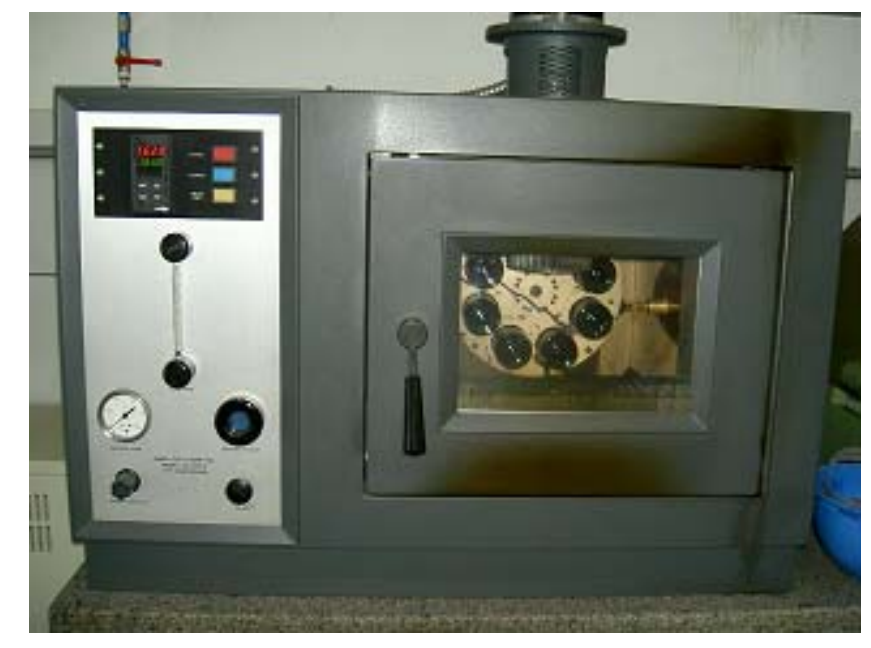

Figura 4.19 - Estufa de Filme Fino Rotativo - RTFOT.

\section{Vaso de Envelhecimento Sob Pressão (Pressure Aging Vessel - PAV)}

O PAV (ASTM D 454) é utilizado para simular as modificações nas propriedades físicas e químicas dos ligantes asfálticos que ocorrem por oxidação em longo prazo, durante a vida em serviço. O ensaio consiste em colocar uma amostra de ligante dentro de um recipiente a uma elevada temperatura, pressurizado a 2,10+0,10 MPa. durante $20 \mathrm{~h}$. A temperatura de ensaio é variável, dependendo da temperatura do local onde vai ser utilizado o asfalto, e varia desde $90^{\circ} \mathrm{C}$ para climas frios até $110^{\circ} \mathrm{C}$ para climas quentes.

Os equipamentos utilizados (Figura 4.20) são: uma estufa, que mantém a temperatura constante durante o ensaio; um sistema controlador da temperatura; um recipiente para 
pressurização; uma fonte de ar limpa e seca sob pressão; um jogo de bandejas normalizadas, cada uma com capacidade para $50 \mathrm{~g}$ de ligante, que controla a espessura das amostras $(3,18$ $\mathrm{mm})$.

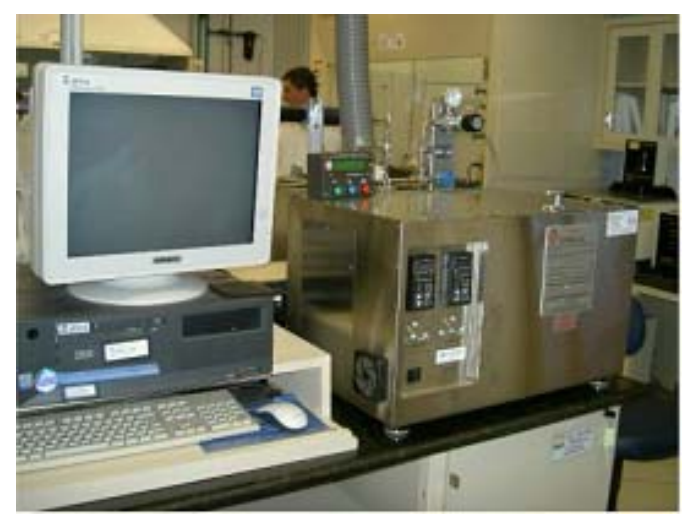

Figura 4.20 - Vaso de Envelhecimento Sob Pressão - PAV.

\section{Reômetro de Viga em Flexão (Bending Beam Rheometer - BBR)}

O BBR (ASTM D 6648) é utilizado para medir o comportamento à flexão, sob baixas temperaturas, dos ligantes asfálticos. Mede o módulo de rigidez estática (S) e o logaritmo do módulo de relaxação (m) Essas propriedades são determinadas a partir da resposta ao carregamento estático (“creep”) sobre uma vigota de ligante asfáltico a baixas temperaturas.

O BBR trabalha aplicando uma carga constante no centro de uma viga prismática bi-apoiada. É especialmente útil para medir módulos entre $30 \mathrm{MPa}$ e $3 \mathrm{GPa}$, os quais são típicos em ligantes asfálticos a temperaturas que vão de -40 até $25^{\circ} \mathrm{C}$, respectivamente. Conhecendo-se a carga aplicada sobre a vigota e medindo-se a deflexão ao longo do teste, a rigidez estática pode ser determinada, usando-se os fundamentos da mecânica. A especificação de ligante estabelece limites para "S" e "m" em função do clima onde o ligante será usado. Ligantes que possuam baixa rigidez estática não trincarão em clima frio. Da mesma forma, ligantes que 
possuam altos valores de "m" são mais eficientes na dissipação das tensões formadas durante a contração do ligante, quando a temperatura do pavimento cai abruptamente, minimizando a formação de trincas e fissuras térmicas.

Alguns ligantes, particularmente alguns modificados com polímero, podem exibir uma rigidez estática a baixa temperatura maior do que o desejado. Entretanto, esses podem não trincar devido à capacidade de deformar sem romper a baixa temperatura. Dessa forma, a especificação permite que o ligante possua uma rigidez maior, desde que se comprove, através do ensaio de tração direta (direct tension test - DTT), que o material possui ductilidade suficiente a baixas temperaturas.

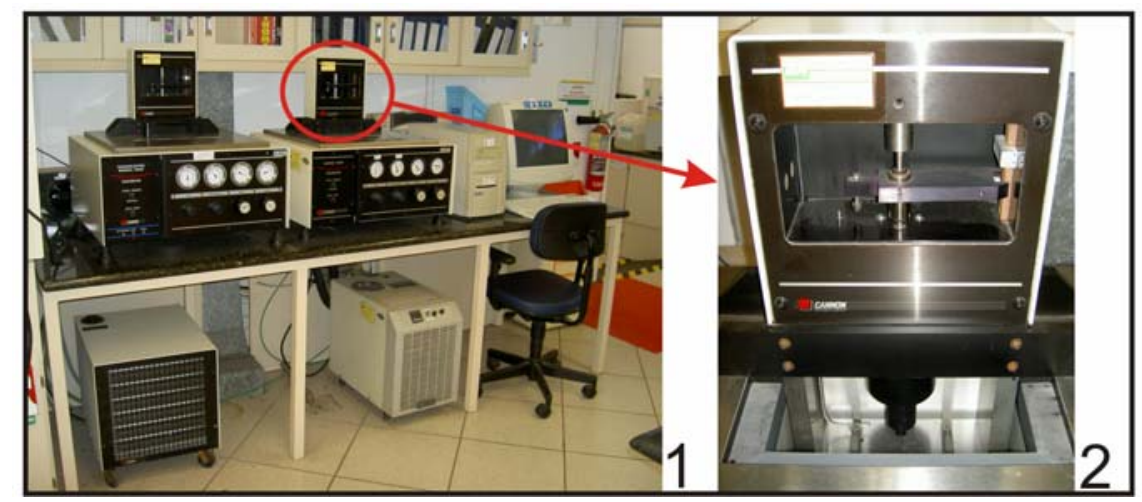

Figura 4.21 - Reômetro de Viga em Flexão - BBR.

\section{Ensaio de Tração Direta (Direct Tension Test - DTT)}

No DTT (ASTM P 252) uma amostra de ligante é submetida à tração até a ruptura. É realizado com o objetivo de analisar o tipo de falha (frágil-dúctil) a baixas temperaturas de serviço assim, se o asfalto apresenta uma deformação unitária menor que $1 \%$ no momento da ruptura, diz-se que a ruptura é frágil. O aparelho consiste simplesmente em dois puxadores, os quais são encarregados de aplicar a tração. 
O puxador inferior permanece fixo enquanto o superior se afasta a uma velocidade constante de $1,00 \mathrm{~mm} / \mathrm{min}$. Nas especificações se limita a deformação unitária mínima a $1 \%$, assegurando um comportamento mais ou menos dúctil a baixas temperaturas de serviço.

\subsubsection{Correlações com as propriedades mecânicas}

Os ensaios que formam parte das especificações Superpave de ligantes asfálticos foram selecionados por vários pesquisadores durante os anos de pesquisa do SHRP, porque apresentaram correlação com ensaios de desempenho em misturas asfálticas. Alguns exemplos dessas correlações, segundo Hicks et al, (1993) são:

- Afundamento de trilhas de roda- Foi verificada relação entre o módulo $\mathrm{G}^{*} / \mathrm{sen} \delta$ de vários ligantes com a profundidade de trilha de roda obtida com misturas betuminosas preparadas com os mesmos ligantes;

- Envelhecimento- as curvas "mestre" de um ligante envelhecido no vaso de envelhecimento sob pressão (PAV) e a obtida com mesmo ligante extraído/recuperado de pavimento são similares, revelando que o teste PAV simula bem o envelhecimento durante a vida em serviço;

- Fadiga- a avaliação de fadiga em trechos experimentais apresentou correlação com o módulo $\left(G^{*}\right.$.sen $\left.\delta\right)$ dos mesmos ligantes utilizados nos trechos experimentais;

- Trincas a baixa temperatura- a temperatura de fratura é definida como aquela em que a tensão térmica induzida é máxima, obtida em ensaios com mistura asfáltica denominado teste de tensão térmica em corpo de prova confinado (TSRST). Existe correlação entre a temperatura de fratura de várias misturas betuminosas e a temperatura em que ocorre a rigidez de fluência máxima (300 MPa) dos mesmos ligantes empregados nas misturas. 
Os ensaios de caracterização dos ligantes asfálticos estudados neste trabalho pelo método Superpave foram realizados no Laboratório de Desenvolvimento Tecnológico da Betunelkoch Asfaltos em Ribeirão Preto - SP, exceto os ensaios de DSR e BBR após envelhecimento no RTFOT/PAV que foram feitos no Centro de Pesquisas e Desenvolvimento Leopoldo A. Miguez de Mello, da Petrobras - CENPES. Os resultados apresentam-se na Tabela 4.4.

Tabela 4.4 - Resultados de caracterização pelo método Superpave dos asfaltos PEN 60/70, AMP SBS Tipo I 60/60 e AMP SBS PG 76 -22.

\begin{tabular}{|c|c|c|c|c|c|c|}
\hline \multirow[b]{2}{*}{ CARACTERISTICAS } & \multirow[b]{2}{*}{$\mathbf{U N}$. } & \multicolumn{3}{|c|}{ LIGANTE ASFÁLTICO } & \multicolumn{2}{|c|}{ MÉTODOS } \\
\hline & & $\begin{array}{c}\text { PEN } \\
60 / 70\end{array}$ & $\begin{array}{c}\text { AMP Tipo I } \\
60 / 60\end{array}$ & $\begin{array}{c}\text { AMP } \\
\text { PG } 76-22\end{array}$ & ABNT & ASTM \\
\hline Penetração (100 g, 5s, $\left.25^{\circ} \mathrm{C}\right)$ & $0,1 \mathrm{~mm}$ & 60 & 49 & 56 & NBR 6576 & D 5 \\
\hline Ponto de amolecimento & ${ }^{\circ} \mathrm{C}$ & 51 & 66 & 68 & NBR 6560 & D 36 \\
\hline \multicolumn{7}{|l|}{ Viscosidade Brookfield } \\
\hline a $135^{\circ} \mathrm{C}$, spindle $21,20 \mathrm{rpm}$, mín & $\mathrm{cP}$ & 455 & 1383 & 1089 & NBR 15184 & D 4402 \\
\hline a $155^{\circ} \mathrm{C}$, spindle $21,20 \mathrm{rpm}$, mín & $\mathrm{cP}$ & 178 & 485 & 581 & NBR 15184 & D 4402 \\
\hline a $175^{\circ} \mathrm{C}$, spindle $21,20 \mathrm{rpm}$, mín & $\mathrm{cP}$ & 81 & 222 & 278 & NBR 15184 & D 4402 \\
\hline DSR - Sem envelhecimento & ${ }^{\circ} \mathrm{C}$ & 64 & 76 & 76 & & P 246 \\
\hline$G^{*}$ & $\mathrm{kPa}$ & 1,975 & 1,445 & 1,017 & & P 246 \\
\hline$\delta$ & $\circ$ & $81,16^{\circ}$ & $64,75^{\circ}$ & $64,09^{\circ}$ & & P 246 \\
\hline $\begin{array}{l}\text { Cisalhamento dinâmico } \\
\text { G*/sen } \delta \geq 1 \mathrm{KPa}\end{array}$ & $\mathrm{kPa}$ & 1,999 & 1,598 & 1,130 & & P 246 \\
\hline \multicolumn{7}{|c|}{ Após envelhecimento RTFOT a $163^{\circ} \mathrm{C}, 85$, min } \\
\hline Variação em massa & $\begin{array}{c}\% \\
\text { massa }\end{array}$ & $-0,518$ & $-0,312$ & $-0,304$ & & D 2872 \\
\hline DSR - após RTFOT & ${ }^{\circ} \mathrm{C}$ & 70 & 76 & 76 & & P 246 \\
\hline$G^{*}$ & $\mathrm{kPa}$ & 3,248 & 3,523 & 3,254 & & P 246 \\
\hline $\boldsymbol{\delta}$ & $\circ$ & $76,28^{\circ}$ & $59,13^{\circ}$ & $59,05^{\circ}$ & & P 246 \\
\hline $\begin{array}{l}\text { Cisalhamento dinâmico } \\
\text { G*/sen } \delta \geq 2,2 \mathrm{KPa}\end{array}$ & $\mathrm{kPa}$ & 3,343 & 4,104 & 3,794 & & P 246 \\
\hline \multicolumn{7}{|c|}{ Após envelhecimento RTFOT/PAV } \\
\hline $\begin{array}{l}\text { Cisalhamento dinâmico } \\
G^{*} \operatorname{sen} \delta \leq 5000 \mathrm{KPa}\end{array}$ & ${ }^{\circ} \mathrm{C}$ & 22 & 19 & 19 & & P 246 \\
\hline $\begin{array}{l}\text { Rigidez a fluência BBR } \\
\mathrm{S} \leq \mathbf{3 0 0 M P a} \text { e } \mathbf{m} \geq \mathbf{0 , 3}\end{array}$ & ${ }^{\circ} \mathrm{C}$ & -22 & -22 & -22 & & D 6648 \\
\hline
\end{tabular}




\subsection{MISTURA ASFÁLTICA}

\subsubsection{Composição granulométrica da Mistura}

A composição granulométrica da mistura, tanto dos agregados peruanos como brasileiros, foi primeiramente analisada pelo método Bailey. como não se encaixaram nas especificações desse método, pois se necessita de agregados com uma boa distribuição granulométrica e com agregados a misturar que tenham uma ampla faixa de superposição, foi determinada a distribuição granulométrica pelo método de "tentativa e erro", ficando a composição granulométrica da mistura com $20 \%$ de pedra $1,20 \%$ de pedrisco e $60 \%$ de pó de pedra, que se encaixa perfeitamente no Método Superpave, como se pode observar na Figura 4.22

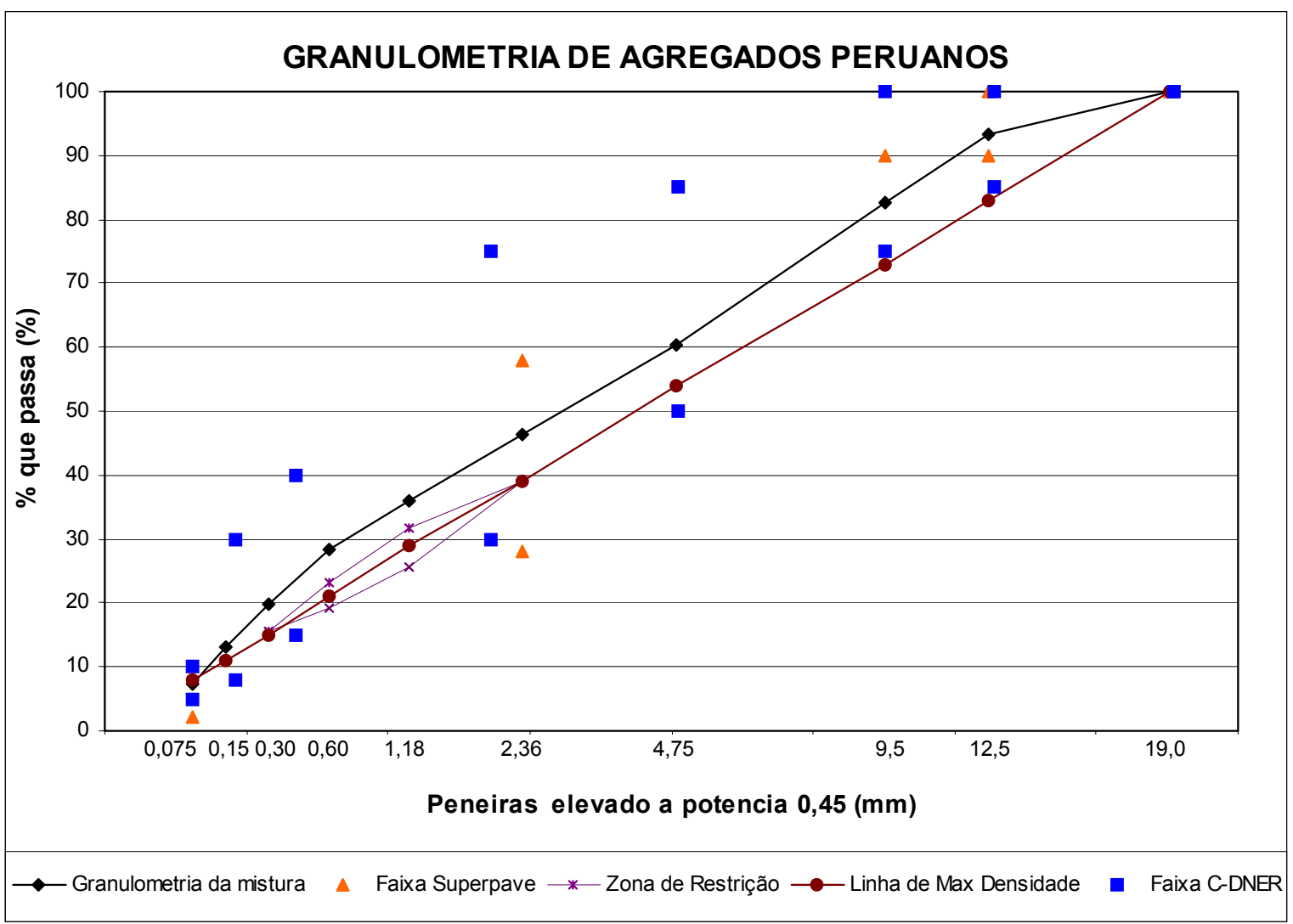

Figura 4.22 - Distribuição granulométrica da Mistura. 


\subsubsection{Seleção e preparação dos agregados minerais}

Para a composição dos corpos de prova, os agregados foram secos em estufa a $110^{\circ} \mathrm{C}$ por aproximadamente 24 horas, para se efetuar um adequado processo de peneiramento.

Os agregados graúdos (pedra 1 e pedrisco) foram peneirados manualmente e o agregado fino (pó de pedra) foi peneirado em três etapas: primeiramente num peneirador mecânico com capacidade de 3 kilogramas por ciclo, com peneiras de $60 \mathrm{~cm}$ x $60 \mathrm{~cm}$, com um tempo de peneiramento de 30 minutos por ciclo com o objetivo de separar a maior quantidade de agregado passado na peneira $\mathrm{N}^{\circ} 200(0,075 \mathrm{~mm})$, devido ao fato de ser o agregado fino o que dificulta o processo de peneiramento da fração fina.

Depois de concluída a primeira etapa, procedeu-se novamente a um peneiramento de todo o agregado fino num peneirador mecânico convencional, com capacidade de 6 peneiras mais o fundo, por 30 minutos por ciclo, para garantir uma adequada separação das frações minerais; uma vez concluída a segunda etapa, procedeu-se um processo de verificação manual, nas peneiras $\mathrm{N}^{\circ} 50(0,300 \mathrm{~mm}), \mathrm{N}^{\circ} 100(0,150 \mathrm{~mm})$ e $\mathrm{N}^{\circ} 200(0,075 \mathrm{~mm})$, para garantir uma adequada separação dos agregados.

Uma vez peneirado nas frações correspondentes a cada uma das peneiras do Superpave, cada uma das frações foram armazenadas individualmente em sacos plásticos, devidamente etiquetados (Figura 4.23), para posterior composição dos corpos de prova, em função da quantidade necessária retida por peneira. 


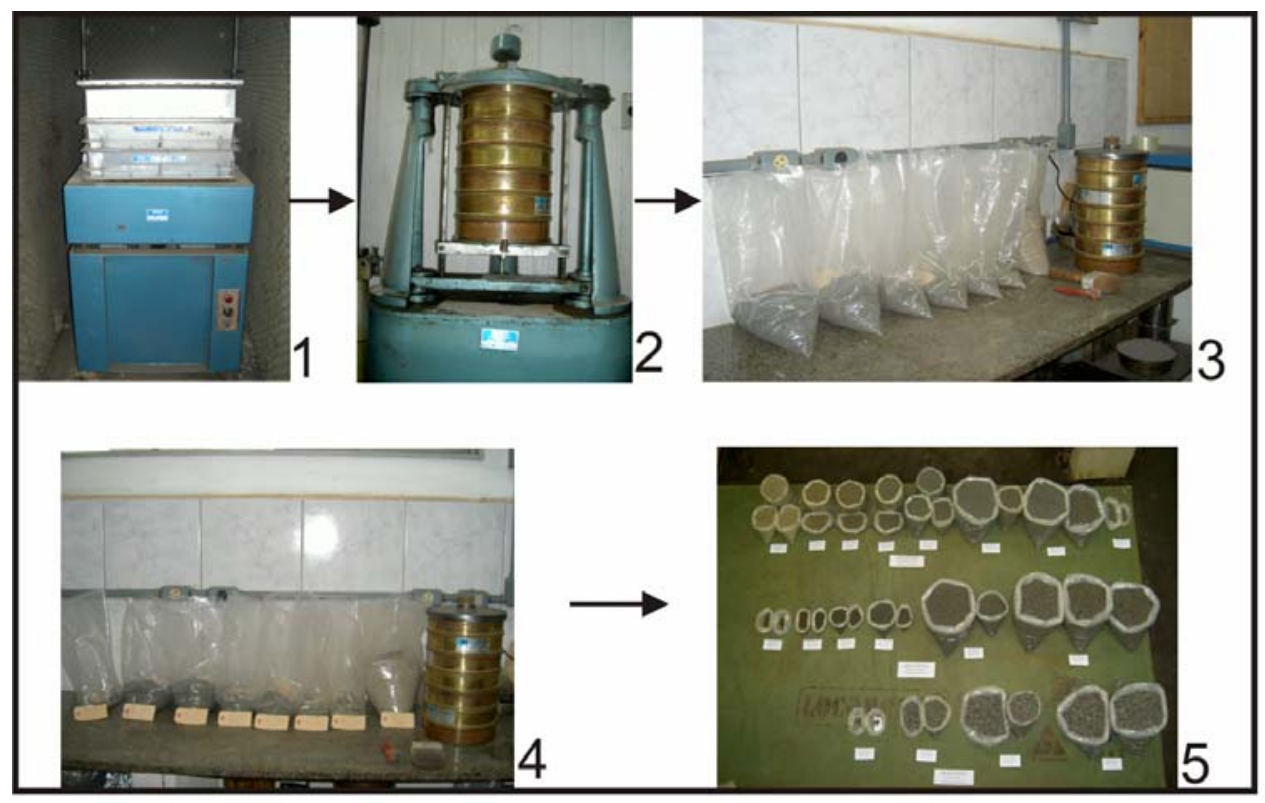

Figura 4.23 - Seleção e preparação dos agregados minerais.

\subsubsection{Dosagem da mistura Betuminosa}

A estimativa da quantidade ótima de ligante asfáltico $\left(\mathrm{P}_{\mathrm{b} 0}\right)$ para dosagem da mistura betuminosa foi feita empregando-se o método da superfície específica, de acordo com a norma DER SP-M 148-60. A seqüência de cálculos está mostrada nos itens de a a d:

a) Cálculo da superfície específica do agregado através da equação 4.9:

$S=\frac{0,17 G+0,33 g+2,30 A+12,0 a+135 f}{100}$

onde:

$\mathrm{S} \quad=$ Superfície específica do agregado, $\mathrm{em}^{2} / \mathrm{kg}$

$\mathrm{G} \quad=$ Porcentagem retida na peneira de $\mathrm{N}^{\circ} 9.52 \mathrm{~mm}$;

$\mathrm{g} \quad=$ Porcentagem passada na peneira de $\mathrm{N}^{\circ} 9.52 \mathrm{~mm}$ e retida na peneira de $\mathrm{N}^{\circ} 4.76 \mathrm{~mm}$; 
A $\quad=$ Porcentagem passada na peneira de $\mathrm{N}^{\circ} 4.76 \mathrm{~mm}$ e retida na peneira de $\mathrm{N}^{\circ} 0.297 \mathrm{~mm}$;

a $\quad=$ Porcentagem passada na peneira de $\mathrm{N}^{\circ} 0.297 \mathrm{~mm}$ e retida na peneira de $\mathrm{N}^{\circ} 0.074 \mathrm{~mm}$;

$\mathrm{f} \quad=$ Porcentagem passada na peneira de $\mathrm{N}^{\circ} 0.074 \mathrm{~mm}$;

b) Cálculo do teor de ligante asfáltico através da equação 4.10 :

$T c a=m \sqrt[5]{S}$

onde:

$\mathrm{T}_{\mathrm{ca}}=$ Teor de asfalto em relação à massa de agregado mineral, em \%;

$\mathrm{m}$ = Módulo de riqueza em asfalto, variável de 3,75 a 4,00;

$\mathrm{S} \quad=$ Superfície especifíca do agregado calculada, $\mathrm{m}^{2} / \mathrm{kg}$;

c) Calculo do teor de ligante asfáltico corrigido através da equação 4.11:

$T^{\prime}{ }_{c a}=\frac{265 \times T_{c a}}{\delta_{a m}}$

onde:

$\mathrm{T}^{\prime}{ }_{\text {ca }}=$ Teor de asfalto corrigido devido à densidade do agregado mineral, em \%;

$\mathrm{T}_{\mathrm{ca}}=$ Teor de asfalto em relação à massa de agregado mineral calculado, em \%;

$\delta_{\mathrm{am}}=$ Densidade do agregado mineral;

d) Calculo da porcentagem de ligante asfáltico através da equação 4.12: 
$P_{c a}=\frac{100 \times T_{c a}^{\prime}}{100+T_{c a}^{\prime}}$

onde:

$\mathrm{P}_{\mathrm{ca}} \quad=$ Porcentagem de asfalto em relação à mistura, em \%;

$\mathrm{T}^{\prime}{ }_{\mathrm{ca}}=$ Teor de asfalto corrigido

Nesta pesquisa, o valor de $\mathrm{P}_{\mathrm{ca}}$ foi de 5,4\%, considerando-se, com base em experiências anteriores, um teor ótimo de 5,5\%, a partir do qual foram calculados os teores de ligante para a moldagem dos corpos de prova: $4,5 \%, 5,0 \%, 5,5 \%, 6,0 \%$ e $6,5 \%$.

A dosagem dos agregados foi feita em função da quantidade necessária retida em cada peneira, sendo a composição dos corpos de prova realizada numa balança com precisão de $0,01 \mathrm{~g}$, com a finalidade de se ter uma mistura com granulometria estritamente controlada, procedimento que foi repetido para cada corpo de prova desenvolvido na pesquisa. A Figura 4.24 mostra o processo de dosagem de agregados realizada para cada corpo de prova.

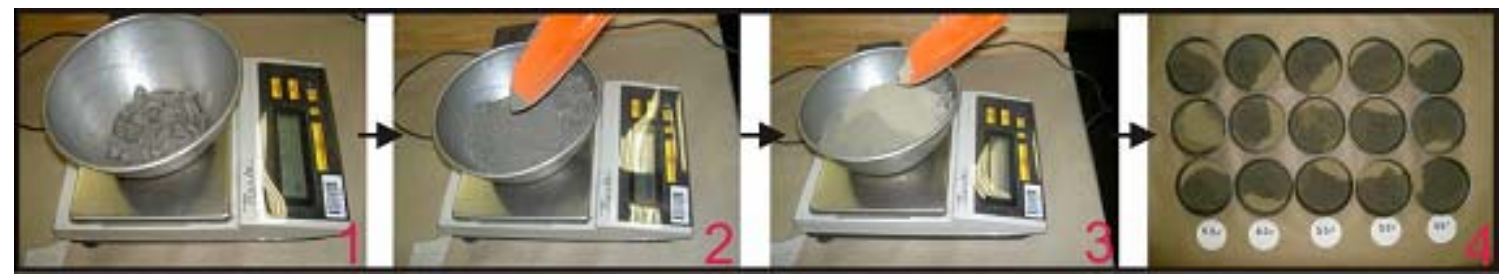

Figura 4.24 - Dosagem controlada de agregados para cada corpo de prova

\subsubsection{Temperaturas de usinagem e compactação da mistura asfáltica}

A Norma ASTM D 2493, (Calculation of Mixing and Compaction Temperatures) estabelece intervalos de temperatura para usinagem e compactação do concreto asfáltico para o ensaio 
Marshall. Esses intervalos estão definidos em função da relação temperatura-viscosidade. A temperatura apropriada para usinagem é aquela na qual o CAP apresenta uma viscosidade Brookfield de $170 \pm 20 \mathrm{cP}$, enquanto que a temperatura de compactação é aquela em que o CAP apresenta uma viscosidade Brookfield de $280 \pm 30 \mathrm{cP}$. Trata-se de um método simples, que proporciona temperaturas razoáveis para ligantes não modificados. Porém, para alguns ligantes modificados essa técnica tem proporcionado altas temperaturas de mistura e compactação, que podem resultar em problemas construtivos, danos ao asfalto e produção de fumaça.

A ASTM D 2493 foi estabelecida para ligantes asfálticos não modificados, os quais se comportam como fluidos Newtonianos a altas temperaturas, ou seja, a viscosidade não depende da taxa de cisalhamento. Porém a maioria dos asfaltos modificados exibe um fenômeno conhecido como pseudoplasticidade segundo o qual a viscosidade depende da taxa de cisalhamento, assim, com as altas taxas de cisalhamento que acontecem durante a mistura e compactação, não é necessário utilizar temperaturas muito altas.

Estudos recentes têm demonstrado que a consideração de um simples valor de viscosidade não é suficiente para caracterizar satisfatoriamente o comportamento reológico dos ligantes modificados a temperaturas elevadas. Resultados de pesquisas apontam o comportamento pseudoplástico dos ligantes modificados como uma característica determinante sobre o efeito da viscosidade na compactação das misturas asfálticas (KHATRI et al., 2001, BAHIA et al., 2001, YILDIRIM, SOLAIMANIAN and KENNEDY, 2000).

A utilização de uma taxa de cisalhamento prática resulta em razoáveis temperaturas de mistura e compactação para projeto e construção de misturas asfálticas a quente com ligantes 
asfálticos modificados. A aplicação do conceito de taxa de cisalhamento em comparação ao método tradicional utilizado para ligantes não modificados, pode reduzir as temperaturas de mistura e compactação aproximadamente entre 10 e $30^{\circ} \mathrm{C}$, dependendo do tipo e quantidade do modificador (YILDIRIM, SOLAIMANIAN, and KENNEDY, 2000).

Nesta pesquisa, para determinar as temperaturas de usinagem e compactação do ligante convencional foram utilizadas as faixas de viscosidade recomendadas pela ASTM, enquanto para os ligantes modificados por polímero foram utilizados as faixas de viscosidades recomendadas pelo fabricante.

A partir dos resultados de caracterização dos ligantes asfálticos PEN 60/70, AMP Tipo I 60/60, AMP PG 76 -22, (Tabela 4.3) foram geradas as Figuras 4.25, 4.26 e 4.27, das quais são obtidos os intervalos de temperaturas para usinagem e compactação do concreto asfáltico, para os três tipos de asfalto (Tabela 4.5).

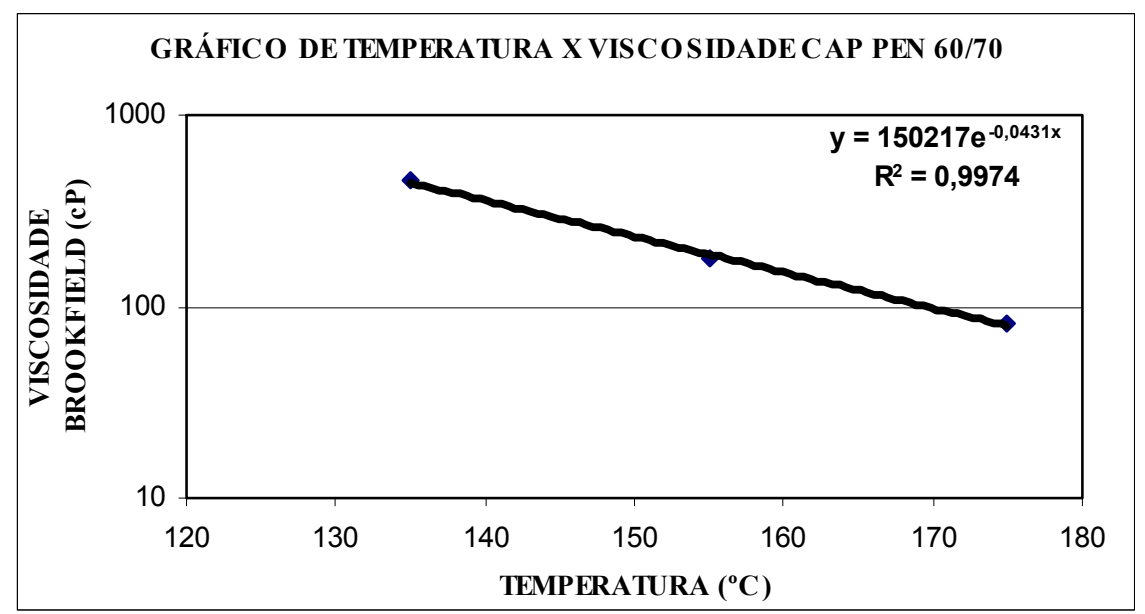

Figura 4.25 - Temperaturas de usinagem e compactação do CAP PEN 60/70. 


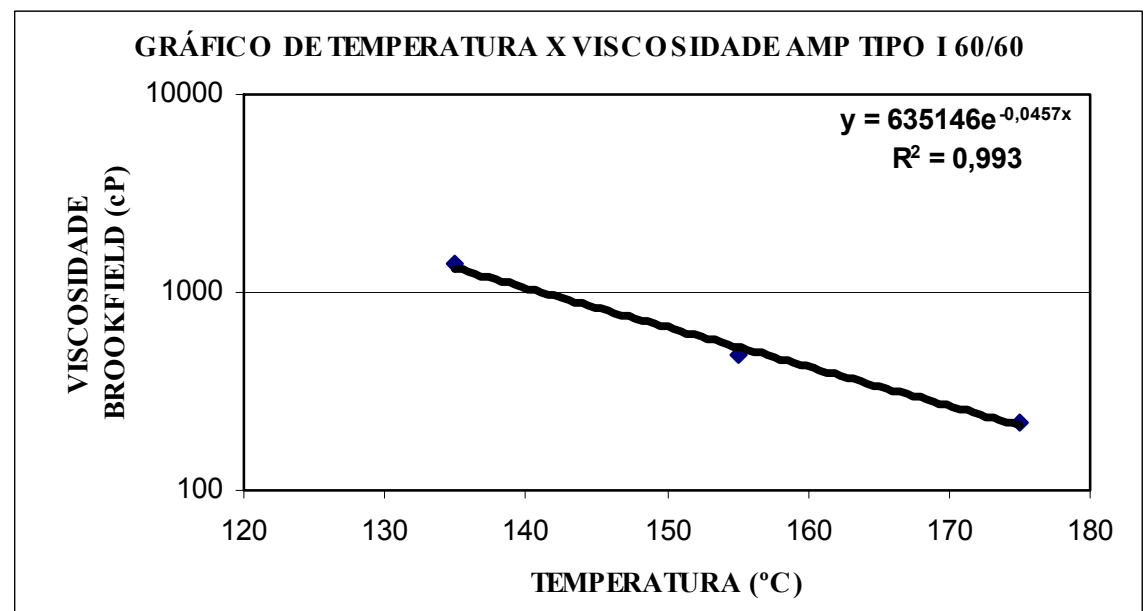

Figura 4.26 - Temperaturas de usinagem e compactação do AMP Tipo I 60/60.

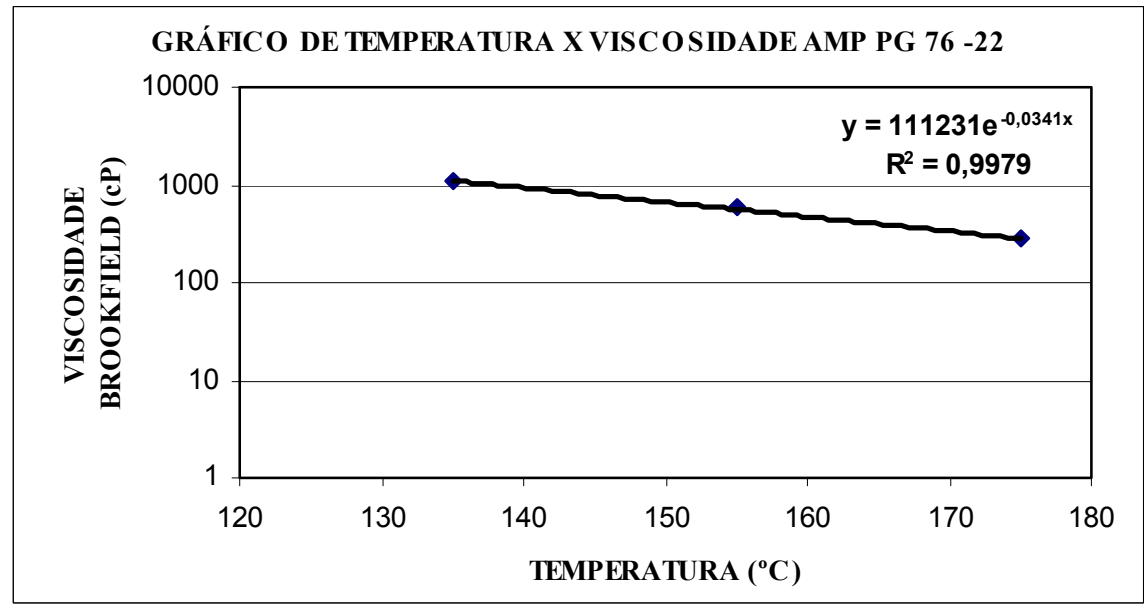

Figura 4.27 - Temperaturas de Usinagem e compactação do AMP PG 76 -22.

Tabela 4.5 - Temperaturas para usinagem e compactação das misturas asfálticas.

\begin{tabular}{cccc}
\hline Temperatura $\left({ }^{\circ} \mathrm{C}\right)$ & PEN 60/70 & AMP Tipo I 60/60 & AMP PG 76 -22 \\
\hline & Temperatura de Usinagem & \\
\hline Agregado mineral & $165^{\circ} \mathrm{C} \mathrm{a} 175^{\circ} \mathrm{C}$ & $171^{\circ} \mathrm{C} \mathrm{a} 182^{\circ} \mathrm{C}$ & $180^{\circ} \mathrm{C} \mathrm{a} 188^{\circ} \mathrm{C}$ \\
Ligante asfáltico & $150^{\circ} \mathrm{C} \mathrm{a} 160^{\circ} \mathrm{C}$ & $161^{\circ} \mathrm{C}$ a $167^{\circ} \mathrm{C}$ & $165^{\circ} \mathrm{C}$ a $173^{\circ} \mathrm{C}$ \\
\hline & Temperatura de Compactação & \\
\hline Concreto asfáltico & $143^{\circ} \mathrm{C} \mathrm{a} 148^{\circ} \mathrm{C}$ & $152^{\circ} \mathrm{C} \mathrm{a} 161^{\circ} \mathrm{C}$ & $153^{\circ} \mathrm{C}$ a $165^{\circ} \mathrm{C}$ \\
\hline
\end{tabular}




\subsubsection{Determinação do teor de projeto - Método Marshall}

A determinação do teor de projeto foi realizada para duas condições:

- sem envelhecimento: segundo a norma DNER-ME 043/95 (Misturas betuminosas a quente - ensaio Marshall), foram moldadas séries de 10 corpos de prova, para cada tipo de ligante asfáltico utilizado na pesquisa, obtendo-se o teor de projeto sem envelhecimento para cada tipo de ligante asfáltico para um volume de vazios de $4 \%$.

- com envelhecimento em curto prazo: segundo a norma ASTM D 6926-04 (Standard practice for preparation of bituminous specimens using Marshall apparatus), para misturas com envelhecimento em curto prazo $(2 \mathrm{~h}$ na estufa à temperatura de compactação), foram moldadas séries de 15 corpos de prova, para cada tipo de ligante asfáltico utilizado na pesquisa, obtendo-se o teor de projeto com envelhecimento em curto prazo para cada tipo de ligante asfáltico para um volume de vazios de $4 \%$.

Os procedimentos para determinar os teores de projeto sem e com envelhecimento em curto prazo consiste basicamente em:

- secagem, análise granulométrica, composição granulométrica da mistura e composição dos corpos de prova;

- estimativa da porcentagem ótima do ligante para o agregado, obtida com base na superfície especifica do agregado (DER SP-M 148-60). O tempo de mistura necessário para o ligante envolver completamente toda a superfície dos agregados, nesta pesquisa, foi de aproximadamente 90 segundos; 
- após a produção das misturas asfálticas, no caso da dosagem sem envelhecimento, essas foram imediatamente compactadas. Porém, para a dosagem com envelhecimento em curto prazo, essas foram armazenadas em estufa à temperatura de compactação por um período de 2 horas, com o objetivo de acondicionar a mistura e simular o envelhecimento e absorção do ligante que acontecem durante o transporte e colocação da mistura em obra;

- moldagem dos corpos de prova por impacto de um soquete padronizado com 4540 gramas de massa e $45 \mathrm{~cm}$ de altura de queda, com 75 golpes para cada face. Na dosagem sem envelhecimento foram moldados 2 corpos de prova para cada teor de ligante (em média 10 corpos de prova para cada tipo de ligante asfáltico, sendo um total de 30 corpos de prova), mas no caso da dosagem com envelhecimento ( 2 h na estufa à temperatura de compactação) foram moldados 3 corpos de prova para cada teor de ligante (em média 15 corpos de prova para cada tipo de AMP e 10 corpos de prova para o CAP virgem, sendo um total de 40 corpos de prova);

- colocação de corpos de prova recém moldados por no mínimo 12 horas à temperatura ambiente, em superfície lisa e plana, com posterior extração dos mesmos de seus respectivos moldes;

- pesagem dos corpos de prova ao ar e imersos em água, para determinação das características físicas;

- determinação das características mecânicas de estabilidade e fluência;

- a escolha de teor de projeto para o presente trabalho foi feita levando em conta o volume de vazios de 4\% conforme preconizado pelo método Superpave, mas atendendo concomitantemente aos demais requisitos da especificação constantes das Tabelas 2.6 e 2.7 (estabilidade, fluência, relação betume-vazios e densidade aparente). 
Os parâmetros necessários à aplicação do método Marshall foram calculados da seguinte forma:

a) Volume de vazios através da equação 4.13:

$V v=100 \times\left(\frac{G_{m m}-G_{m b}}{G_{m m}}\right)$

onde:

$\mathrm{Vv}=$ Volume de vazios;

$\mathrm{G}_{\mathrm{mm}}=$ Densidade teórica máxima medida;

$\mathrm{G}_{\mathrm{mb}}=$ Densidade aparente da mistura.

b) Volume de vazios preenchidos pelo asfalto através da aquação 4.14:

$V b=\left(\frac{G_{m b} \times \% b}{G_{b}}\right)$

onde:

$\mathrm{Vb}=$ Volume de vazios preenchido pelo betume, (\%);

$\mathrm{G}_{\mathrm{mb}}=$ Densidade aparente da mistura;

$\% \mathrm{~b}=$ Porcentagemde betume, $(\%)$;

$\mathrm{G}_{\mathrm{b}} \quad=$ Densidade real de massa de betume. 
c) Porcentagem de vazios do agregado mineral através da equação 4.15:

$V A M=\mathrm{V} v+\mathrm{Vb}$

onde:

VAM= Porcentagem de vazios do agregado mineral, (\%);

$\mathrm{Vv}=$ Volume de vazios, $(\%)$;

$\mathrm{Vb}=$ Volume de vazios preenchidos pelo betume, $(\%)$.

d) Relação betume vazios através da equação 4.16:

$R B V=\frac{100 \times \mathrm{Vb}}{\mathrm{VAM}}$

onde:

$\mathrm{RBV}=$ Relação betume vazios, (\%);

$\mathrm{Vb}=$ Volume de vazios preenchido pelo asfalto, $(\%)$

$\mathrm{VAM}=$ Porcentagem de vazios do agregado mineral,(\%).

\subsubsection{Densidade Aparente}

A densidade aparente foi determinada com base na norma DNER-ME 117/94, pesando-se os corpos-de-prova primeiramente secos e depois submersos e empregando-se o peso específico da água por meio da equação 4.17:

$G_{m b}=\frac{M_{a r}}{M_{a r}-M_{\text {agua }}}$ 
onde:

$\mathrm{G}_{\mathrm{mb}}=$ Densidade aparente da mistura;

$\mathrm{M}_{\mathrm{ar}} \quad=$ Massa do corpo de prova ao ar, $(\mathrm{g})$

$\mathrm{M}_{\mathrm{agua}}=$ Massa do corpo de prova imerso em água, $(\mathrm{g})$.

\subsubsection{Densidade Máxima Teórica (Método Rice)}

O Método Rice (ASTM D 2041/00) permite a determinação da massa específica máxima teórica medida e a densidade da mistura asfáltica não compactada a $25^{\circ} \mathrm{C}(\mathrm{Gmm})$. A massa específica máxima teórica é usada no cálculo dos vazios de ar na mistura asfáltica compactada, no cálculo da quantidade de ligante absorvido pelo agregado, além de fornecer valores de projeto para compactação das misturas asfálticas.

O ensaio consiste em colocar uma amostra de mistura asfáltica, em quantidade que depende do tamanho nominal máximo do agregado em condição fofa, em um recipiente com água à temperatura aproximada de $25^{\circ} \mathrm{C}$, até submersão total da amostra. Em seguida, aplica-se gradualmente vácuo para reduzir a pressão residual dentro do recipiente para $30 \mathrm{mmHg}$ ou menos, que será mantida por $15 \pm 2$ minutos sob agitação mecânica. Ao fim desse período de tempo, o vácuo é gradualmente eliminado. O volume da amostra da mistura é obtido complementando-se o nível do recipiente com água e pesando-se ao ar, sendo a massa e a temperatura anotadas. A partir das medidas de massa, calcula-se a massa específica ou densidade real da mistura, corrigindo-a para a temperatura de $25^{\circ} \mathrm{C}$.

Foram realizados ensaios em misturas com os três tipos de ligante asfáltico, sendo um convencional PEN 60/70, um AMP Tipo I 60/60 e um AMP PG 76 -22. Para cada mistura, na 
etapa da dosagem, foram feitos ensaios com cada teor de ligante e, posteriormente, foram calculadas as densidades máximas teóricas $(\mathrm{Gmm})$ para o teor de projeto e condição de envelhecimento dos três asfaltos utilizados. Segundo a ASTM 2041/00, a precisão do ensaio mostra que, para ser aceita a média de dois resultados feitos em amostras conduzidas adequadamente, é necessário que a diferença entre as duas determinações não ultrapasse 0,023, precisão válida para um mesmo operador.

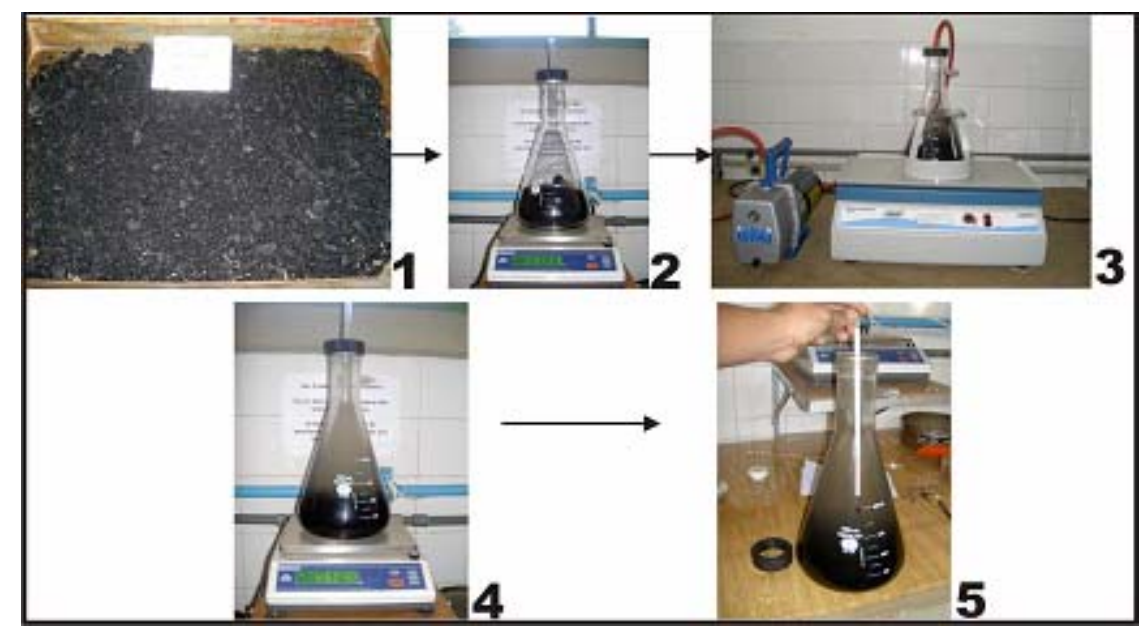

Figura 4.28 - Ensaio de Densidade Máxima Teórica (Método Rice).

\subsubsection{Absorção de asfalto pelo agregado}

Através da $\mathrm{Gmm}$, do teor de asfalto $(\mathrm{Pb})$ e da densidade aparente dos agregados (Gsb), calcula-se a densidade efetiva da mistura $\left(\rho_{\mathrm{ef}}\right)$, cujo valor é usado no cálculo da absorção do asfalto $\left(\mathrm{Abs}_{\mathrm{asf}}\right)$. A $\rho_{\mathrm{ef}}$ pode ser obtida através da equação 4.18:

$$
\rho e f=\frac{1-P b}{\frac{1}{G m m}-\frac{P b}{\rho b}}
$$


onde:

$\rho_{\mathrm{ef}} \quad=$ Densidade efetiva da mistura;

$\mathrm{Pb}=$ Teor de asfalto;

Gmm = Densidade Teórica máxima medida;

$\rho b \quad=$ Densidade do asfalto.

A absorção de asfalto pode ser determinada pela equação 4.19:

$$
A b s_{a s f}=\frac{\rho e f-G s b}{\rho e f \times G s b} \times \rho b \times 100
$$

onde:

$\mathrm{Abs}_{\text {asf }}=$ Absorção de asfalto;

$\rho_{\mathrm{ef}} \quad=$ Densidade efetiva da mistura;

Gsb = Densidade aparente do agregado;

$\rho b \quad=$ Densidade do asfalto.

\subsubsection{Moldagem dos corpos de prova}

Os corpos de prova foram moldados com teor de projeto calculado para cada condição de envelhecimento e tipo de ligante asfáltico, para realização dos ensaios de módulo de resiliência, resistência à tração, umidade induzida, vida de fadiga, fluência por compressão uniaxial estática e dinâmica. O processo de moldagem foi feito sem envelhecimento, com envelhecimento em curto prazo de 2 horas, segundo a ASTM D 6926-04, e com envelhecimento em curto prazo de 4 horas, segundo a AASHTO PP2. 
O processo consiste, primeiramente, em preparar um traço da mistura com aproximadamente 1200 g de material para confecção de cada CP. Em seguida, o ligante e o agregado são aquecidos às temperaturas pré-definidas (Tabela 4.5). Mistura-se o ligante ao agregado até que o agregado fique completamente coberto pelo ligante (um a dois minutos). As misturas sem envelhecimento foram compactadas e as misturas com envelhecimento em curto prazo (2 e 4 horas) foram submetidas às respetivas condições de envelhecimento e compactadas, com 75 golpes em cada uma das faces do corpo-de-prova.

Após a compactação, os corpos de prova foram resfriados à temperatura ambiente dentro dos cilindros, com o objetivo de não se deformarem durante o processo de extração do molde. Após o desmolde do corpo-de-prova, foi verificado o volume de vazios, encontrando-se todos na faixa de $4 \pm 0,25 \%$. Posteriormente, foram efetuadas quatro medidas de altura e diâmetro para obtenção do valor médio das dimensões dos corpos de prova.

Durante o desenvolvimento desta pesquisa foram moldados um total de 196 corpos-de-prova, cuja distribuição é apresentada na Tabela 4.6. 
Tabela 4.6 - Quantidade de corpos de prova utilizados por ensaio.

\begin{tabular}{|c|c|c|c|}
\hline \multicolumn{4}{|c|}{ DOSAGEM MARSHALL } \\
\hline Objetivo & PEN 60/70 & Tipo I 60/60 & PG $76-22$ \\
\hline Dosagem Marshall sem envelhecimento & 10 & 10 & 10 \\
\hline Dosagem Marshall com $2 \mathrm{~h}$ de envelhecimento & 10 & 15 & 15 \\
\hline$N^{\circ}$ de Corpos de Prova & 20 & 25 & 25 \\
\hline \multicolumn{4}{|c|}{ MISTURA SEM ENVELHECIMENTO } \\
\hline Objetivo & PEN 60/70 & Tipo I 60/60 & PG $76-22$ \\
\hline Ensaio de MR, RT e Umidade Induzida & 6 & 6 & 6 \\
\hline Ensaio Creep Estático, Dinâmico e Fadiga & 8 & 8 & 8 \\
\hline$N^{\circ}$ de Corpos de Prova & 14 & 14 & 14 \\
\hline \multicolumn{4}{|c|}{ MISTURA COM 2 h DE ENVELHECIMENTO } \\
\hline Objetivo & PEN 60/70 & Tipo I 60/60 & PG $76-22$ \\
\hline Ensaio de MR, RT e Umidade Induzida & 6 & 6 & 6 \\
\hline Ensaio Creep Estático, Dinâmico e Fadiga & 8 & 8 & 8 \\
\hline$N^{\circ}$ de Corpos de Prova & 14 & 14 & 14 \\
\hline \multicolumn{4}{|c|}{ MISTURA COM 4 h DE ENVELHECIMENTO } \\
\hline Objetivo & PEN 60/70 & Tipo I 60/60 & PG $76-22$ \\
\hline Ensaio de MR, RT e Umidade Induzida & 6 & 6 & 6 \\
\hline Ensaio Creep Estático,dinâmico e Fadiga & 8 & 8 & 8 \\
\hline$N^{\circ}$ de Corpos de Prova & 14 & 14 & 14 \\
\hline \multicolumn{3}{|c|}{ QUANTIDADE TOTAL DE CORPOS DE PROVA UTILIZADOS } & 196 \\
\hline
\end{tabular}

\subsubsection{Ensaios para determinação das propriedades das misturas asfálticas}

Os ensaios em misturas asfálticas que foram realizados na presente pesquisa com o objetivo de avaliar as propriedades mecânicas do asfalto são:

- ensaio Marshall (estabilidade e fluência);

- ensaio de módulo de resiliência por compressão diametral;

- ensaio de resistência à tração por compressão diametral;

- ensaio de dano por umidade induzida; 
- ensaio de fadiga por compressão diametral a tensão controlada;

- ensaio de fluência por compressão uniaxial estática e dinâmica.

\subsubsection{Estabilidade e fluência Marshall}

Segundo a norma DNER ME 043/95 a estabilidade é definida como a resistência máxima à compressão radial apresentada pelo corpo de prova, expressa em N (kgf). E a fluência é definida como a deformação total apresentada pelo corpo de prova, no momento da aplicação da carga máxima, expressa em décimos de milímetro (centésimos de polegada).

Para determinação da estabilidade Marshall, o corpo de prova deve ser submetido, durante um período de 30 a 40 minutos, a um banho de água sob temperatura de $60^{\circ} \mathrm{C}$, posteriormente, é colocado no molde e submetido à deformação, com uma taxa de 2 polegadas por minuto, até que se dê a ruptura, medindo-se nesse instante a carga máxima que a produziu (valor da estabilidade). Conforme o teor de ligante aumenta no sentido da porcentagem ótima, ocorre um aumento na estabilidade Marshall e um aumento na resistência às deformações. Neste trabalho, o ensaio foi realizado segundo a norma DNER ME 043/95 (Figura 4.29).

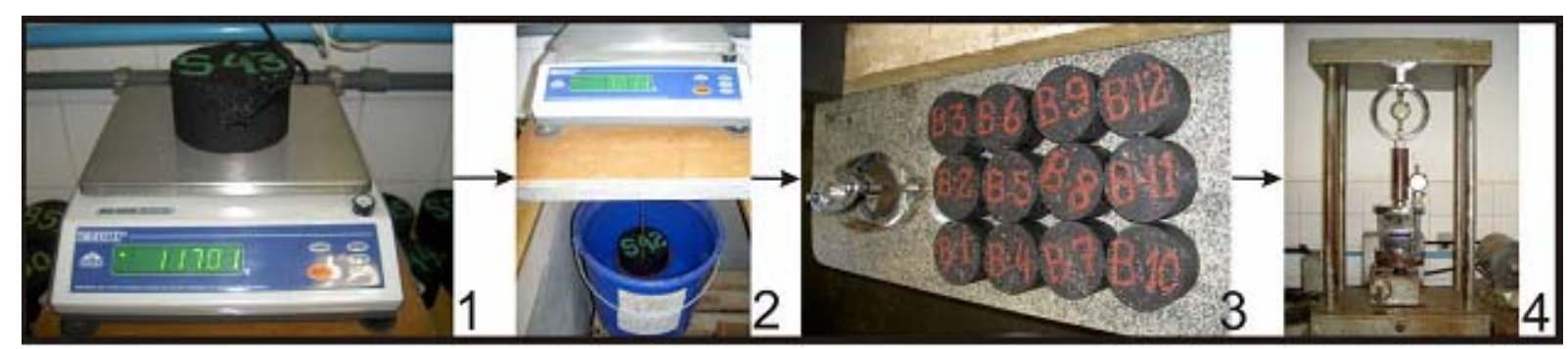

Figura 4.29 - Ensaio de Estabilidade e fluência Marshall. 


\subsubsection{Ensaio de Módulo de Resiliência}

Segundo o DNER, o módulo de resiliência (MR) de misturas asfálticas é a relação entre a tensão de tração $\left(\sigma_{t}\right)$, aplicada repetidamente no plano vertical de uma amostra cilíndrica de mistura asfáltica, e a deformação específica recuperável $\left(\varepsilon_{t}\right)$, correspondente à tensão aplicada, numa dada temperatura $(\mathrm{T})$.

O ensaio de módulo de resiliência visa simular as condições encontradas no campo, onde os materiais que constituem o revestimento asfáltico são submetidos a carregamentos de curta duração originados pela ação do tráfego. A deformação específica resiliente, ou recuperável, é medida por um LVDT (Linear Variable Differential Transducer) acoplado a um sistema de aquisição de dados e posicionado no plano perpendicular ao sentido do carregamento. Dessa forma, consegue-se avaliar o comportamento da mistura na zona onde ocorrem as deformações de tração, responsáveis pela fadiga da camada (MOURÃO, 2003).

A norma ASTM D 4123-82, de ensaio de módulo de resiliência por tração indireta, introduz o conceito de determinação dessa propriedade em mais de uma temperatura de referência. A vantagem desse procedimento é que a comparação entre diferentes tipos de ligantes é mais rica, pois verifica a variação de comportamento elástico com a variação da temperatura. Os valores recomendados na norma da ASTM para a temperatura do ensaio são: $5^{\circ} \mathrm{C}, 25^{\circ} \mathrm{C}$ e $40^{\circ} \mathrm{C}$, com recomendação de mais de uma freqüência de aplicação de carga.

A norma AASHTO TP 31-96, especifica o ensaio de módulo de resiliência, referindo-se também à determinação em três temperaturas diferentes $\left(5^{\circ} \mathrm{C}, 25^{\circ} \mathrm{C}\right.$ e $\left.40^{\circ} \mathrm{C}\right)$, e freqüência de $1 \mathrm{~Hz}$, com $0,1 \mathrm{~s}$ de aplicação total de carga e $0,9 \mathrm{~s}$ de repouso. 
Nesta pesquisa, foram definidos dois níveis de temperatura para determinação do Módulo de resiliência: $5^{\circ} \mathrm{C}$ e $25^{\circ} \mathrm{C}$ (Figura 4.30 e 4.31 ). Após a definição das temperaturas de ensaio, passou-se à definição dos valores para o coeficiente de Poisson a ser considerado nos cálculos do módulo de resiliência. Como os equipamentos de Ensaios Dinâmicos do Laboratório de Estradas da EESC não dispõem de medidores de deformação vertical, o valor do coeficiente de Poisson foi adotado. Barksdale et al. (1997), sugerem que o coeficiente de Poisson para as temperaturas de ensaio adotadas deve estar entre os seguintes limites:

$5^{\circ} \mathrm{C}: \quad \mu=0,1$ a 0,3

$25^{\circ} \mathrm{C}: \quad \mu=0,25$ a 0,45

Medina (1997) sugere que seja adotado o valor de 0,30 para o valor do coeficiente de Poisson, o qual foi adotado nesta pesquisa para as duas temperaturas de ensaio $\left(5^{\circ} \mathrm{C}\right.$ e $\left.25^{\circ} \mathrm{C}\right)$.

Para a determinação do módulo de resiliência foram utilizados 27 corpos de prova. Os procedimentos do ensaio realizado no Laboratório de Estradas do Departamento de Engenharia de Transportes da Escola de Engenharia de São Carlos da Universidade de São Paulo (STT-EESC-USP) são:

- moldagem do corpo de prova, conforme procedimentos descritos no ensaio Marshall. Foram confeccionados em média 9 corpos de prova com teor de projeto, para cada tipo de ligante asfáltico, sendo um total de 27 corpos de prova;

- medição da altura (H) e diâmetro (D) do corpo de prova com paquímetro, em quatro posições diametralmente opostas. Adotou-se a média aritmética das quatro leituras; 
- colocação do corpo de prova num ambiente com temperatura de ensaio desejada, no caso 5 e $25^{\circ} \mathrm{C}$, por um período mínimo de 24 horas;

- posicionamento do corpo de prova na estrutura de suporte, fixação e ajuste do transdutor mecânico - magnético, tipo LVDT, de modo a se obter o registro dos deslocamentos;

- posicionamento preciso do pistão de carga na rótula da estrutura de suporte da amostra;

- aplicação de carga até obter uma taxa de deformação na faixa de 0,002 a 0,003 , com o objetivo de aplicar uma carga que produza essa deformação durante o ensaio;

- aplicação de 100 ciclos de carregamento vertical (F), diametralmente, no corpo-de-prova, à taxa de deformação na faixa de 0,002 a 0,003. A freqüência de aplicação da carga (f) é de 1 $\mathrm{Hz}$, ou seja, 60 ciclos por minuto, com duração de $0,1 \mathrm{~s}$ de carregamento e $0,9 \mathrm{~s}$ de recuperação. O registro dos deslocamentos resilientes é obtido para todas as aplicações da carga vertical $(\mathrm{F})$;

- com os dados obtidos são calculados os módulos de resiliência, com auxilio do programa computacional desenvolvido em Lab View, utilizando a equação 4.20:

$$
M R=\left(\frac{F}{100 \times \Delta \times H}\right) \times(0,9976 \times \mu+0,2692)
$$

onde:

$\mathrm{MR}=$ Módulo de resiliência $(\mathrm{MPa})$;

$\mathrm{F} \quad=$ Carga vertical repetida aplicada diametralmente no corpo de prova $(\mathrm{N})$;

$\Delta \quad=$ Deformação elástica ou resiliente ;

$\mathrm{H}=$ Altura do corpo-de-prova $(\mathrm{cm})$

$\mu \quad=$ Coeficiente de Poisson (adimensional) 


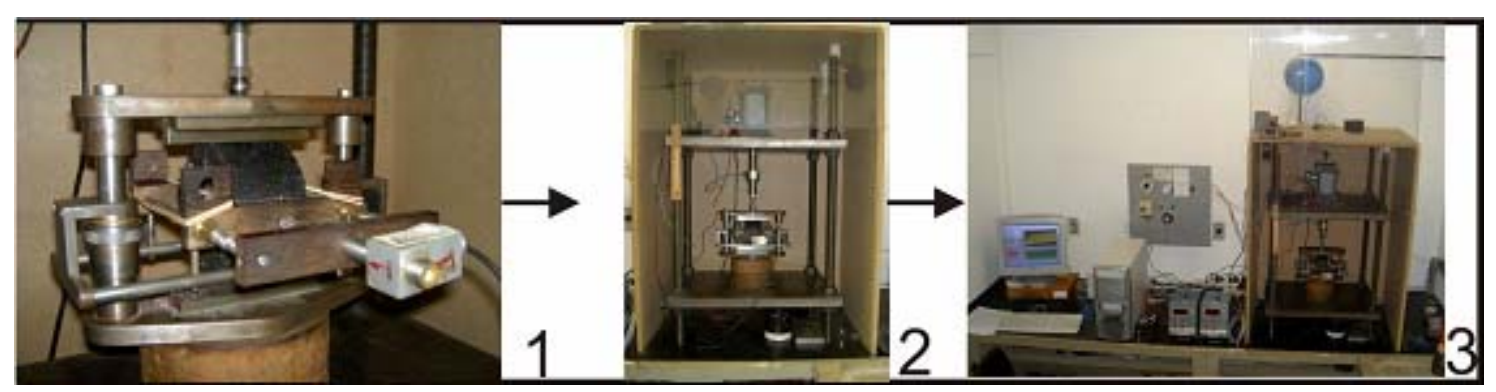

Figura 4.30 - Ensaio de Módulo de Resiliência a $25^{\circ} \mathrm{C}$.

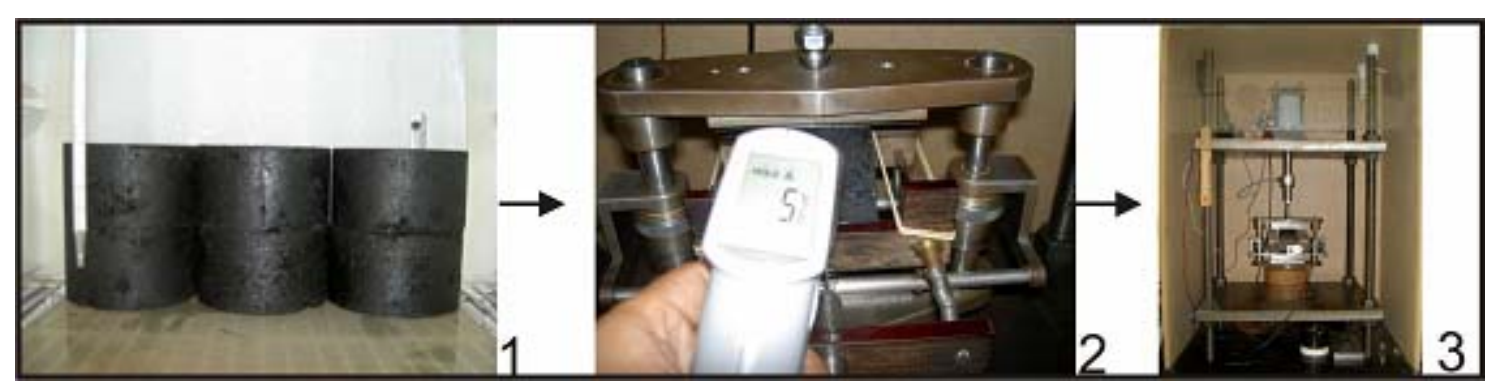

Figura 4.31 - Ensaio de Módulo de Resiliência a $5^{\circ} \mathrm{C}$.

\subsubsection{Resistência à Tração}

O ensaio de resistência à tração por compressão diametral ou tração indireta, conhecido internacionalmente como "Ensaio Brasileiro", foi desenvolvido pelo Professor Fernando Luiz Lobo Carneiro para determinar a resistência à tração de corpos de prova de concreto através de carregamento estático. O corpo de prova cilíndrico é posicionado diametralmente em relação à direção da compressão, resultando numa tração agindo perpendicularmente ao longo do plano diametral, que promove a ruptura do corpo de prova nessa direção. Neste trabalho foi realizado numa prensa Marshall, onde o corpo de prova é apoiado ao longo de suas geratrizes por dois frisos de carga posicionados na parte superior e inferior do corpo de prova, sendo a carga aplicada progressivamente, com uma velocidade de deformação de $0,8 \pm 0,1$ $\mathrm{mm} / \mathrm{s}$. O objetivo deste ensaio é determinar a resistência à tração indireta de corpos de prova cilíndricos de misturas asfálticas. 
Para o ensaio foram moldados, em média, 12 corpos de prova para cada tipo de ligante asfáltico utilizado, num total de 36 corpos de prova. O ensaio foi realizado em duas temperaturas $\left(5\right.$ e $\left.25^{\circ} \mathrm{C}\right)$ com a finalidade de avaliar o efeito da temperatura baixa (Figura 4.32 e 4.33). Os procedimentos do ensaio adotado, segundo o DNER-ME 138/94, são:

- medição da altura $(\mathrm{H})$ e diâmetro (D) do corpo de prova com paquímetro, em quatro posições diametralmente opostas. Adotou-se, a média aritmética das quatro leituras;

- coloca-se o corpo de prova num ambiente climatizado ou sistema de refrigeração por um período de 24 horas, de modo a se obter a temperatura especificada para o ensaio ( 5 e $25^{\circ} \mathrm{C}$ ). Em seguida, é colocado em posição horizontal, repousando segundo uma geratriz, sobre o prato inferior da prensa. Verifica-se visualmente a retilinearidade das geratrizes de contato com ambos os pratos;

- ajustam-se os pratos da prensa até que seja obtida uma leve compressão, capaz de manter em posição o corpo de prova;

- aplica-se a carga progressivamente, com uma velocidade de deformação de $0,8 \pm 0,1$ $\mathrm{mm} / \mathrm{s}$, até a ruptura, por separação do corpo de prova em duas metades, segundo o plano diametral vertical, e anota-se a carga de ruptura $(\mathrm{F})$;

- é calculada a resistência à tração do corpo de prova, utilizando-se a equação 4.21.

$$
\sigma_{F}=\frac{2 F}{\pi D H}
$$

onde:

$\sigma_{\mathrm{R}} \quad=$ Resistência à tração $\left(\mathrm{Kgf} / \mathrm{cm}^{2}\right)$;

$\mathrm{F} \quad$ = Carga de ruptura (Kgf); 
D = Diâmetro do corpo-de-prova $(\mathrm{cm})$;

$\mathrm{H} \quad=$ Altura do corpo-de-prova $(\mathrm{cm})$.

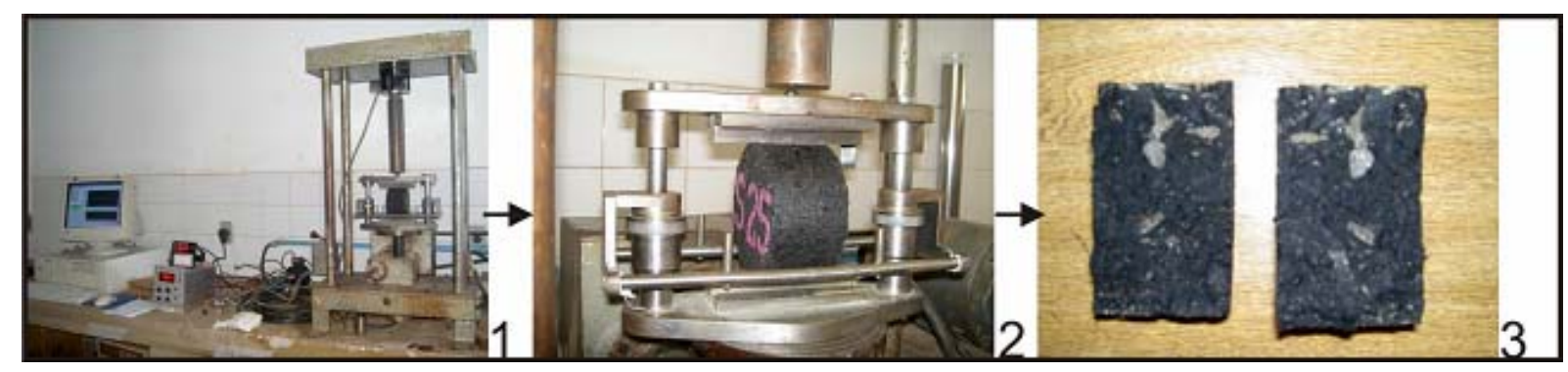

Figura 4.32 - Ensaio de Resistência à Tração a $25^{\circ} \mathrm{C}$.

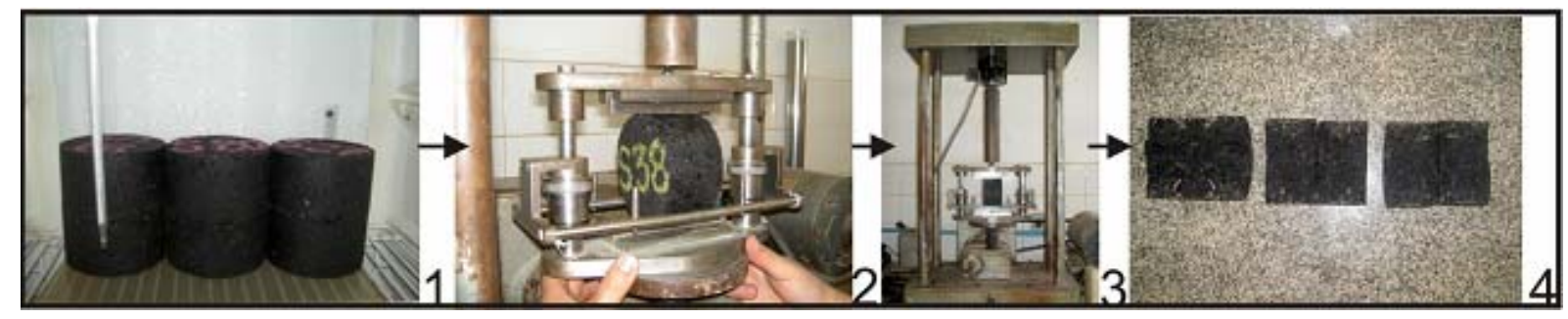

Figura 4.33 - Ensaio de Resistência à Tração a $5^{\circ} \mathrm{C}$.

\subsubsection{Resistência à tração retida por umidade induzida}

A sensibilidade das misturas à umidade associa-se a dois mecanismos que se interrelacionam: a perda de adesão e a perda de coesão. A perda de adesão deve-se à existência de água entre o asfalto e o agregado, causando o descolamento do filme de asfalto. Já a perda de coesão se dá devido ao enfraquecimento do asfalto na presença de água, que diminui a resistência da união asfalto/agregado, causando uma redução severa na resistência e integridade da mistura (FURLAN et al., 2004).

A susceptibilidade de misturas asfálticas à umidade é um problema complexo, que depende de fatores ambientais, práticas construtivas e características das misturas asfálticas. Os principais 
fatores que aceleram o aparecimento dos danos causados pela umidade são o clima e o tráfego. Os maiores danos ocorrem em condições climáticas extremas, particularmente quando ocorre congelamento combinado com alto volume de tráfego. Os fatores construtivos que influenciam a sensibilidade da mistura à umidade incluem a qualidade da compactação e as condições climáticas durante o processo de construção do pavimento. Dentre as características das misturas asfálticas, destacam-se a natureza do agregado, a natureza do asfalto e o tipo da mistura.

Levando-se em consideração todos os fatores descritos, o dano causado pela umidade nas misturas asfálticas afeta diretamente o desempenho e a vida de serviço dos pavimentos, por isso, com o intuito de avaliar melhor a adesividade, foi realizado o ensaio de resistência à tração retida por umidade induzida.

Nesta pesquisa, o ensaio foi realizado seguindo o procedimento descrito na AASHTO T 283. Os corpos de prova (CPs) foram preparados em laboratório seguindo o método Marshall, sendo utilizados $6 \mathrm{CPs}$ por cada tipo de ligante asfáltico, num total de $18 \mathrm{CPs}$. O procedimento de ensaio pode ser resumido através dos passos descritos a seguir:

- saturar os CPs, aplicando uma pressão de 254 - 660 mmHg, a fim de obter saturação entre 55 e $80 \%$;

- colocar os CPs para congelamento $\left(-18^{\circ} \mathrm{C}\right)$ por um período mínimo de $16 \mathrm{~h} \pm 1 \mathrm{~h}$. Os CPs devem ser cobertos por um filme plástico e colocados dentro de um saco vedado com 10 $\mathrm{ml}$ de água;

- imergir os CPs em um banho a $60^{\circ} \mathrm{C}$ por um período de $24 \pm 1 \mathrm{~h}$, após a retirada do filme e do saco plástico; 
- retirar os CPs do banho a $60^{\circ} \mathrm{C}$ e imergi-los em um banho a $25^{\circ} \mathrm{C}$ por um período de 2 horas $\pm 10 \mathrm{~min}$;

- realizar o ensaio de resistência à tração nos CPs após todo o ciclo de condicionamento (RTu);

- calcular a resistência à tração retida (RTR) por umidade induzida, que e a razão entre a resistência à tração após umidade induzida $(\mathrm{RTu})$ e a RT.

A Figura 4.34 apresenta alguns passos adotados no processo de condicionamento e ensaio de RTu dos CPs.

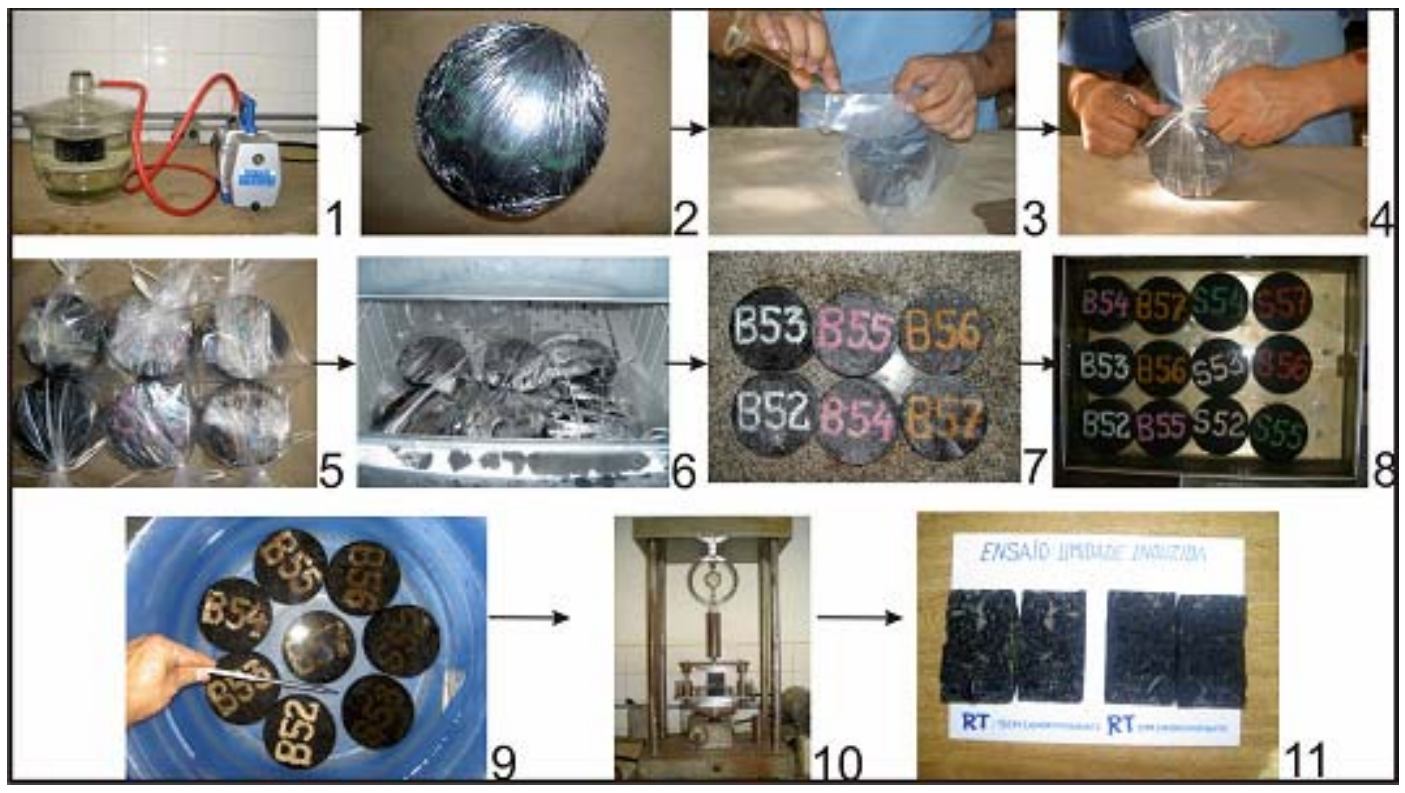

Figura 4.34 - Ensaio de Resistência à Tração retida por umidade induzida.

\subsubsection{Fluência por Compressão Uniaxial Estática ("creep estático")}

Trata-se de um ensaio que tem sido utilizado para estimar a susceptibilidade das misturas asfálticas convencionais à deformação permanente, sob diferentes condições de carregamento e temperatura. Little, Button, e Youssef (1993) desenvolveram critérios para avaliar o 
potencial do concreto asfáltico à deformação permanente por meio do ensaio de fluência por compressão uniaxial, que, segundo eles, é eficiente para identificar a sensibilidade das misturas de concreto asfáltico à deformação permanente. $\mathrm{O}$ ensaio apresenta sensibilidade às variáveis da mistura, tais como: tipo de asfalto, teor de ligante, tipo de agregado, teor de vazios, temperatura de ensaio e estado de tensões. Para tanto, o ensaio deve ser realizado em condições de temperatura e nível de tensão próximas das observadas no campo, a temperatura deve ser de $40^{\circ} \mathrm{C}$ e a tensão na faixa de 3,5 a $4,15 \mathrm{kgf} / \mathrm{cm}^{2}$. Os dados obtidos do ensaio de fluência por compressão uniaxial estática são: deformação total para uma hora de carregamento $\left(\varepsilon_{\mathrm{p}}\right)$, inclinação do estágio secundário da curva deformação versus tempo de carregamento $(\mathrm{m})$, em escala $\log -\log$, e o módulo de fluência $\left(\mathrm{S}_{\mathrm{c}}\right)$. $\mathrm{O}$ estágio secundário é determinado entre 1000 e 3600 segundos.

Segundo Coelho (1996), o ensaio de fluência por compressão uniaxial estática consiste na aplicação de uma carga de compressão uniaxial estática a um corpo de prova cilíndrico, durante um período de tempo de uma hora, e descarga de 15 minutos. A aplicação da carga de compressão é realizada por meio de uma prensa pneumática e as leituras das deformações axiais dos corpos-de-prova são feitas através de dois LVDT's alinhados. A temperatura de ensaio utilizada é de $40^{\circ} \mathrm{C}$, por ser um valor normalmente observado na literatura (TAIRA, 2001), com um período de pré-condicionamento térmico dos corpos de prova à temperatura de ensaio, por um período de no mínimo 10 horas.

Segundo o Instituto Brasileiro de Petróleo (1996) e Valkering, et al. (1990), os ensaios clássicos de caracterização de misturas betuminosas (Marshall e fluência por compressão uniaxial estática), que utilizam cargas constantes, não permitem que os corpos de prova se comportem elasticamente, subestimando o aumento da resistência à deformação permanente 
nos asfaltos modificados, embora sejam úteis para prever a resistência à deformação permanente nas misturas com asfalto convencional.

No ensaio de fluência por compressão uniaxial estática nota-se a falta de padronização das pressões, tempo de carregamento e descarregamento, da temperatura de ensaio, das dimensões do corpo de prova e dos parâmetros para a avaliação das misturas asfálticas, por ser um ensaio ainda não normalizado. Neste trabalho, foi realizado a uma temperatura de $40^{\circ} \mathrm{C}$ e com nível de tensão de $4 \mathrm{kgf} / \mathrm{cm}^{2}$, conforme intervalo de tensões proposto por Little, Button e Youssef (1993), e com prato superior de carregamento de aproximadamente $102 \mathrm{~mm}$ de diâmetro, em uma prensa composta de sistema pneumático, com temperatura controlada por meio de um dispositivo automático conectado a uma fonte de calor. A prensa está localizada em uma câmara, dotada de abertura para permitir manuseio do corpo de prova. O equipamento dispõe de medidores do tipo célula de carga e LVDT, que permitem o registro eletrônico das cargas e deslocamentos, bem como o processamento dos resultados e obtenção da curva de fluência, tornando dessa forma, todo o procedimento mais rápido e eficaz. Foi utilizado um programa aplicativo em Labwiew, versão 7.0 para Windows. Foram utilizados 9 CPs com teor de projeto, para cada tipo de ligante asfáltico, num total de 27 CPs. Os procedimentos do ensaio realizado no Laboratório de Estradas do STT-EESC-USP são (Figura 4.35):

- préviamente ao ensaio, as faces dos corpos de prova foram lixadas, com a finalidade de regularizar a superfície de contato. Posteriormente, uma fina capa de vaselina foi aplicada nas duas faces, para evitar o atrito na interface com as placas de carregamento e de apoio da prensa;

- condicionamento térmico dos corpos de prova na temperatura prevista para o ensaio $\left(40^{\circ} \mathrm{C}\right)$, por um período mínimo de 10 horas (TAIRA, 2001); 
- pré-condicionamento do corpo de prova mediante a aplicação, durante cinco minutos, da carga de ensaio, seguido de um período de cinco minutos de recuperação do corpo de prova;

- após a recuperação, inicia-se o ensaio com a aplicação da carga de ensaio, que é mantida durante um período de sessenta minutos;

- em seguida a carga é retirada e o deslocamento axial permanente $\left(\Delta_{75}\right)$ é medido a cada sessenta segundos, até completar o tempo de recuperação do ensaio, normalmente com duração de quinze minutos;

- a deformação total, inclinação da curva de fluência, recuperação elástica e módulo de fluência são calculadas através das equações 4.22, 4.23, 4.24 e 4.25:

$$
\varepsilon_{t}=\frac{\Delta h_{t}}{h_{0}}
$$

$m=\frac{\log \varepsilon_{3600}-\log \varepsilon_{1000}}{0,5563}$

$R=\frac{\varepsilon_{3600}-\varepsilon_{v p}}{\varepsilon_{3600}}$

$S_{c}=\frac{\sigma}{\varepsilon_{t}}$

onde: 
$\varepsilon_{\mathrm{t}}, \varepsilon_{1000}, \varepsilon_{3600}, \varepsilon_{\mathrm{vp}}=$ Deformação axial específica, respectivamente, em qualquer instante t; para 1000 e 3600 segundos de ensaio, e visco-plástica (após a recuperação);

$\Delta \mathrm{h}_{\mathrm{t}}$ $=$ Variação da altura do corpo de prova em qualquer instante $\mathrm{t}(\mathrm{mm})$;

$\mathrm{h}_{0}$ $=$ Altura inicial do corpo de prova, tomada na direção do carregamento, em mm;

$\mathrm{R}$

= Recuperação elástica;

$\sigma$

= Nível de tensão do ensaio.

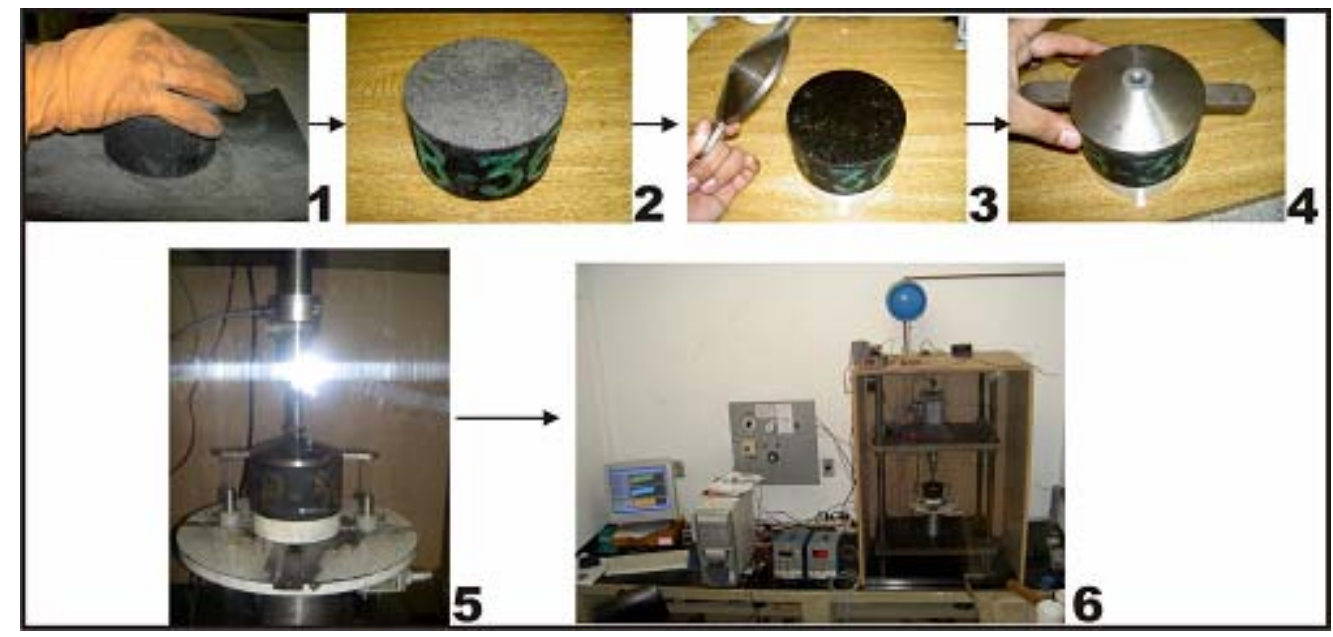

Figura 4.35 - Ensaio de Fluência por Compressão Uniaxial Estática (creep estático).

\subsubsection{Fluência por Compressão Uniaxial Dinâmica ("creep dinâmico")}

Segundo Valkering et al. (1990) e Tayebali (1992), o "static creep test" é capaz de avaliar o efeito do asfalto na estabilidade da mistura em termos de deformação permanente para asfaltos convencionais, entretanto, quando o asfalto é modificado por polímeros, em particular pelo SBS, o comportamento reológico é alterado, e o ensaio estático não é mais capaz de avaliar a mistura, o que não acontece com o ensaio dinâmico. A deformação permanente acumulada, obtida sob carregamento dinâmico, representa melhor o potencial para a 
deformação permanente em misturas contendo asfalto modificado. O ensaio dinâmico consiste de aplicações de cargas de compressão uniaxial com um tempo de duração curto (geralmente $0,1 \mathrm{~s}$ ), seguida de um intervalo de repouso (geralmente $0,9 \mathrm{~s}$ ).

Segundo Mohamed e Yue, (1994), a carga repetitiva uniaxial de compressão em amostras cilíndricas de concreto asfáltico simula as cargas repetidas do tráfego nos pavimentos asfálticos. Através desse tipo de ensaio é possível obter, para todas as amostras, uma taxa constante de deformação permanente acumulada e, através dessa taxa, é possível avaliar a susceptibilidade da amostra ensaiada à deformação permanente.

Para misturas betuminosas contendo asfalto modificado, os ensaios com aplicação de carga dinâmica parecem representar melhor o potencial de deformação permanente nas trilhas de roda (Tayebali, 1992). Assim como o "static creep test", o ensaio dinâmico também não é padronizado. Na Tabela 4.7 mostram-se algumas especificações citadas por vários autores. 
Tabela 4.7 - Exemplos de tempos de carregamento e repouso, tensão de carregamento e temperatura de ensaio segundo vários autores.

\begin{tabular}{|c|c|c|c|c|}
\hline Pesquisador (es) & $\begin{array}{l}\text { Tempo de } \\
\text { carga (s) }\end{array}$ & $\begin{array}{l}\text { Tempo de } \\
\text { repouso (s) }\end{array}$ & $\begin{array}{c}\text { Tensão de } \\
\text { carregamento } \\
\text { kPa }\end{array}$ & $\begin{array}{c}\text { Temp. do ensaio } \\
\left({ }^{\circ} \mathrm{C}\right)\end{array}$ \\
\hline MAJIDZADEH e KHEDR (1979) & 0,125 & 0,375 & $206,7-402,4$ & $27-38-49$ \\
\hline VALKERING et al. (1990) & 0,2 & 1,8 & 100 & $40-50$ \\
\hline SRIVASTAVA et al (1992) & 0,9 & 5,4 & - & 40 \\
\hline HANSON et al (1994) & 0,1 & 0,9 & $827^{* *}$ & $* * *$ \\
\hline MOHAMED e YUE (1994) & 0,2 & 1,8 & 690 & $25-40$ \\
\hline CORTÉ et al. (1994) & 0,2 & 1,8 & 100 & 40 \\
\hline SOUSA et al. (1993 apud S Á e MOTTA 1995) & 0,1 & 0,6 & 69 & 60 \\
\hline SÁ e MOTTA (1995) & 0,1 & 0,9 & $100-400$ & $25-45$ \\
\hline ULMGREN (1997) & 1 & 1 & 100 & $* * *$ \\
\hline QI e WITCZAK (1998) & 0,1 & 0,1 & 138 & 38 \\
\hline TAIRA e FABBRI (1999) & 0,2 & 1,8 & 100 & 40 \\
\hline
\end{tabular}

\footnotetext{
* Utilização de prensa eletro-hidráulica

** Pressão de confinamento de $138 \mathrm{kPa}$

*** Temperatura não especificada
}

Fonte: MUGAYAR, (2004)

O ensaio de compressão uniaxial dinâmico é similar ao ensaio estático, descrito anteriormente, porém, como o próprio nome evidencia, o carregamento é feito através da aplicação de pulsos de carga, com um tempo de duração de $0,1 \mathrm{~s}$, intercalados com um tempo de repouso de $0,9 \mathrm{~s}$, num total de 5000 pulsos, e um período de pré-condicionamento que consiste na aplicação de 200 ciclos de carregamento com a tensão de ensaio. O aparelho e as condições de temperatura e tensões utilizadas no desenvolvimento do ensaio dinâmico foram 
os mesmos utilizados no ensaio de fluência por compressão uniaxial estática. A Figura 4.36 apresenta os procedientos do ensaio de fluência por compressão uniaxial dinâmico.

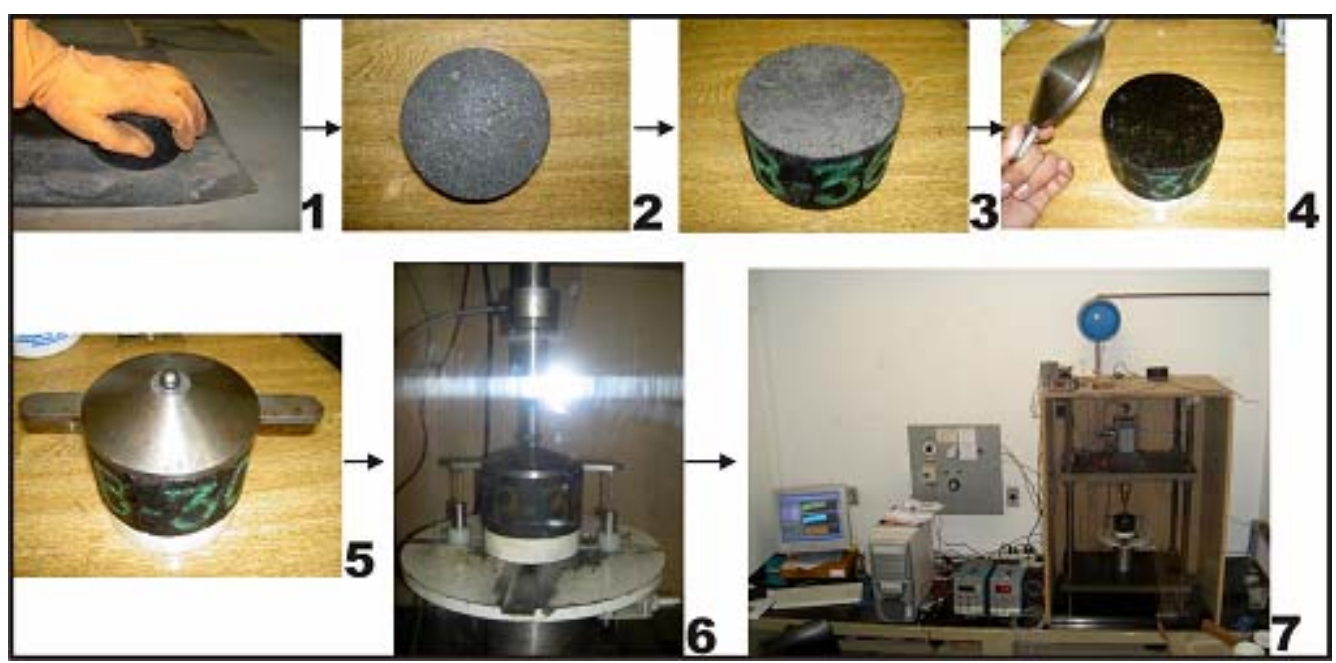

Figura 4.36 - Ensaio de Fluência por Compressão Uniaxial Dinâmica (creep dinâmico).

\subsubsection{Ensaio de Fadiga por compressão diametral}

A vida de fadiga de um material asfáltico pode ser dita como o número de aplicações de carga necessário para que a mistura atinja ruptura ou um deslocamento vertical maior a $6 \mathrm{~mm}$ (definido no laboratório de estradas do STT-EESC-USP) sob dado estado de tensões. No ensaio de fadiga por compressão diametral com tensão controlada, a carga aplicada é mantida constante e as deformações resultantes aumentam no decorrer do ensaio. Consiste na aplicação de um ciclo de carregamento com duração de 0,1 segundo, com 0,9 segundos de intervalo, para representar o tempo de intervalo entre a aplicação de uma roda e outra. Nesse tipo de ensaio, o corpo de prova está sujeito a um estado bi-axial de tensões.

Foram moldados 24 corpos de prova para cada tipo de ligante asfáltico utilizado, num total de 72 corpos de prova. Devido ao fato do ensaio de fadiga em mistura asfáltica ainda não estar 
normalizado no Brasil é realizado com base na literatura nacional e na experiência de outros centros de pesquisa, como COPPE/UFRJ e UFRGS (SANTOS, 2005).

O ensaio foi realizado por compressão diametral à tensão controlada, aplicando-se cargas verticais repetidas de tal forma que as tensões geradas correspondessem aos valores de 20, 30, 40 e 45 \% da resistência à tração (RT). Os procedimentos do ensaio realizados no Laboratório de Estradas do STT-EESC-USP são (Figura 4.37):

- medição da altura $(\mathrm{H})$ e diâmetro (D) do corpo de prova com um paquímetro, em quatro posições opostas, adotando-se a média aritmética das quatro leituras;

- posicionamento do corpo de prova na estrutura de suporte, centralização, fixação e ajuste do transdutor mecânico - magnético tipo LVDT, de modo a se obter o registro do deslocamento vertical;

- posicionamento preciso do pistão de carga na rótula da estrutura de suporte de amostras;

- determinação do carregamento vertical, de acordo com a RT, e o nível de tensão de acordo com a equação (4.26).

$$
F=\frac{100 \cdot \pi \cdot D \cdot H \cdot(\% R T)}{2}
$$

onde:

$\mathrm{F} \quad=$ Carga aplicada $(\mathrm{N})$

D = Diâmetro do corpo de prova $(\mathrm{cm})$

$\mathrm{H} \quad=$ Altura do corpo de prova $(\mathrm{cm})$

$(\% \mathrm{RT})$ = Nível de carga em relação à $\mathrm{RT}(\mathrm{MPa})$ 
- preencher os dados do corpo de prova (diâmetro, altura, carga e \% de deformação vertical) no programa de fadiga em LabView, desenvolvido no Departamento de Transportes da EESC-USP;

- abrir a válvula da entrada do ar, ligar o controlador, colocar na posição certa o aparelho do início de carga e dar início ao ensaio;

- a carga aplicada é dinâmica pulsatória, com freqüência de aplicação de $1 \mathrm{~Hz}$, com tempo de aplicação de carga de 0,1 segundo e repouso de 0,9 segundos;

- a aplicação de ciclos de carga e as deformações correspondentes são registradas no programa. Quando não ocorre a divisão do corpo de prova em duas partes, durante o ensaio, o critério de ruptura adotado no laboratório é de $6 \mathrm{~mm}$ de deslocamento vertical, que finaliza automaticamente ficando registrados os dados no computador;

- calcula-se a diferença de tensões $(\Delta \sigma)$ e a deformação resiliente (ci), segundo as equações (4.27) e (4.28) respectivamente.

$$
\Delta \sigma=\frac{8 F}{100 \cdot \pi \cdot d \cdot h}
$$

$$
\varepsilon_{i}=\frac{(\% R T)}{M R}
$$

onde:

$$
\begin{aligned}
\Delta \sigma & =\text { Diferença de tensões no centro do corpo de prova (MPa); } \\
\mathrm{F} & =\text { Carga aplicada }(\mathrm{N}) ; \\
\mathrm{d} & =\text { Diâmetro do corpo de prova }(\mathrm{cm}) ; \\
\mathrm{h} & =\text { Altura do corpo de prova }(\mathrm{cm}) ; \\
\varepsilon_{\mathrm{i}} & =\text { Deformação resiliente }
\end{aligned}
$$


$\mathrm{RT}=$ Resistência à tração $(\mathrm{MPa})$

$\mathrm{MR}=$ Módulo de resiliência $(\mathrm{MPa})$

- representação das curvas de fadiga em um gráfico dilog, com os números de solicitações de carga que levaram à ruptura do corpo de prova nas ordenadas e as diferenças de tensões e deformações que levaram à ruptura nas abscissas. Determina-se a curva de fadiga para o material com as equações (4.29) e (4.30).

$N=k 1\left(\frac{1}{\Delta \sigma}\right)^{k 2}$

$N=k 3\left(\frac{1}{\Delta \varepsilon}\right)^{k 2}$

onde:

$\mathrm{N}=$ Número de aplicações de carga na ruptura, no fim do ensaio;

$\Delta \sigma \quad=$ Diferença de tensões no centro do corpo de prova (MPa)

$\Delta \varepsilon \quad=$ Diferença de deformações no centro do corpo de prova $(\mathrm{MPa})$

k1, k2 e k3= Parâmetros determinados no ensaio.

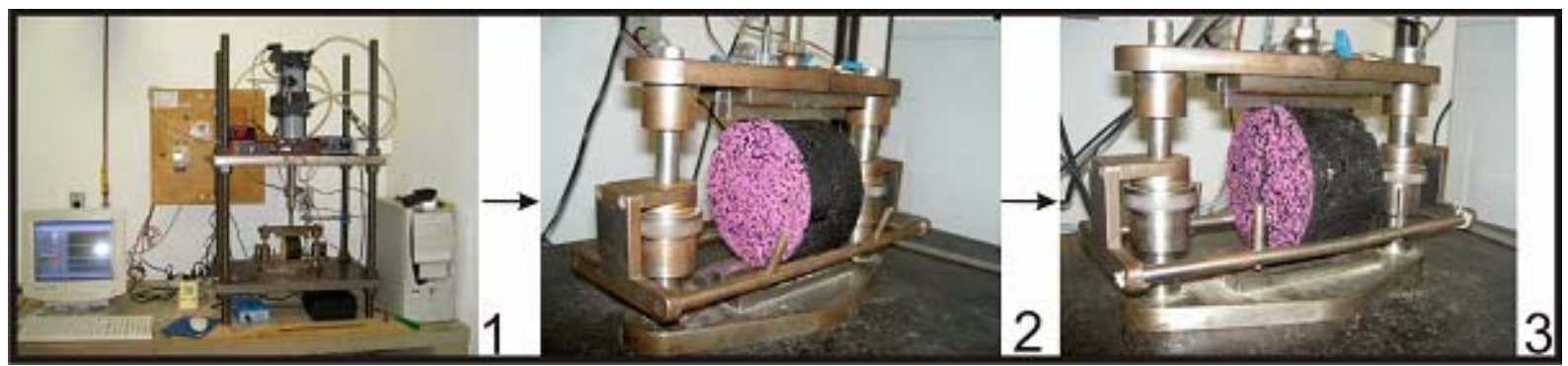

Figura 4.37 - Ensaio de Fadiga por compressão diametral. 
4.3.6 Programa computacional para controle dos ensaios de módulo de resiliência, fluência por compressão uniaxial estática, fluência por compressão diametral dinâmica e fadiga.

No processo da aquisição de dados para a determinação do módulo de resiliência, dos parâmetros de fluência estática, dinâmica e fadiga das misturas estudadas nesta pesquisa, foram utilizados programas computacionais, desenvolvidos em linguagem LabView, da National Instruments Corp. (1996), pelo Professor Dr. Glauco Túlio Pessa Fabri.

O programa armazena a leitura dos deslocamentos medidos através de LVDT's e da força através de célula de carga, podendo adquirir até 1000 dados por segundo, gravando os resultados em formato texto (txt), o que permite a verificação e/ou manipulação dos dados em planilhas eletrônicas. 


\section{APRESENTAÇÃO E ANÁLISE DOS}

\section{RESULTADOS DE LABORATÓRIO}

\subsection{INTRODUÇÃO}

Nesta seção são apresentados e analisados os resultados obtidos do estudo e distribuição do grau de desempenho de ligantes asfálticos do Peru, ensaios em agregados, cimentos asfálticos, dosagem das misturas betuminosas, estabilidade e fluência Marshall, resistência à tração, resistência à tração retida por umidade induzida, módulo de resiliência, fadiga por compressão diametral a tensão controlada, fluência por compressão uniaxial estático e dinâmico.

\subsection{DISTRIBUIÇÃO DO GRAU DE DESEMPENHO DE LIGANTES ASFÁLTICOS DO PERU}

Da análise dos resultados, podem-se determinar, em termos gerais, os graus de desempenho PG dos ligantes asfálticos requeridos nas diferentes regiões do Peru.

Para as regiões do litoral Pacífico, que compreendem a região entre 0 e 500 m de altitude, e parte dos vales interandinos da região "Yunga", que vão até $800 \mathrm{~m}$ de altitude e cujo clima é caracterizado por pouca precipitação (média de $50 \mathrm{~mm}$ por ano), os ligantes asfálticos indicados são o PG 64-10 e o PG 70-10. 
Para a região da Serra, que compreende as regiões geográficas de "Yunga", "Quéchua", "Suni" e "Puna", localizadas entre 800 e $4800 \mathrm{~m}$ de altitude, com relevo natural muito acidentado pela cordilheira dos Andes, com climas variados, temperaturas que dependem da altitude do local e precipitações que variam de $100 \mathrm{~mm}$ até $1000 \mathrm{~mm}$ ao ano, os ligantes asfálticos indicados são: PG 58-10, PG 58-16, PG 58-22, PG 52-10, PG 52-16, PG 52-22. As regiões mais frias da Serra estão localizadas na serra central, no departamento de Junin, província de Yauli, e na serra Sul, entre os Departamentos de Cusco, província de Espinar, Arequipa, província de Caylloma e no Departamento de Puno nas províncias de Melgar, San Roman, Lampa, Puno, Collao e Chucuito, considerado a região mais fria do Peru.

Para a região da Selva, localizada entre 80 e $1000 \mathrm{~m}$ de altitude, cujas precipitações variam entre 1500 e 4000 mm por ano, a classificação PG dos ligantes asfálticos está compreendida entre o PG 64-10 e o PG 70-10.

\subsection{AGREGADOS}

\subsubsection{Granulometria}

A curva granulométrica da mistura adotada atendeu aos critérios do Superpave para um Diâmetro Máximo Nominal de $12,5 \mathrm{~mm}$, passando entre os pontos de controle e acima da zona de restrição, além de se enquadrar dentro da faixa C do DNER, conforme pode ser observado na Figura 5.1. Pode-se observar, também que a granulometria da mistura é quase paralela à linha de máxima densidade, o que representa uma boa distribuição granulométrica da mistura. É importante ressaltar que apesar de haver a recomendação para que a curva passe 
por fora da zona de restrição, vários pesquisadores já constataram que a zona de restrição não é capaz de prever curvas granulométricas com baixo desempenho quanto à deformação permanente, recomendando inclusive sua eliminação como critério de desempenho (HAND et al., 2001).

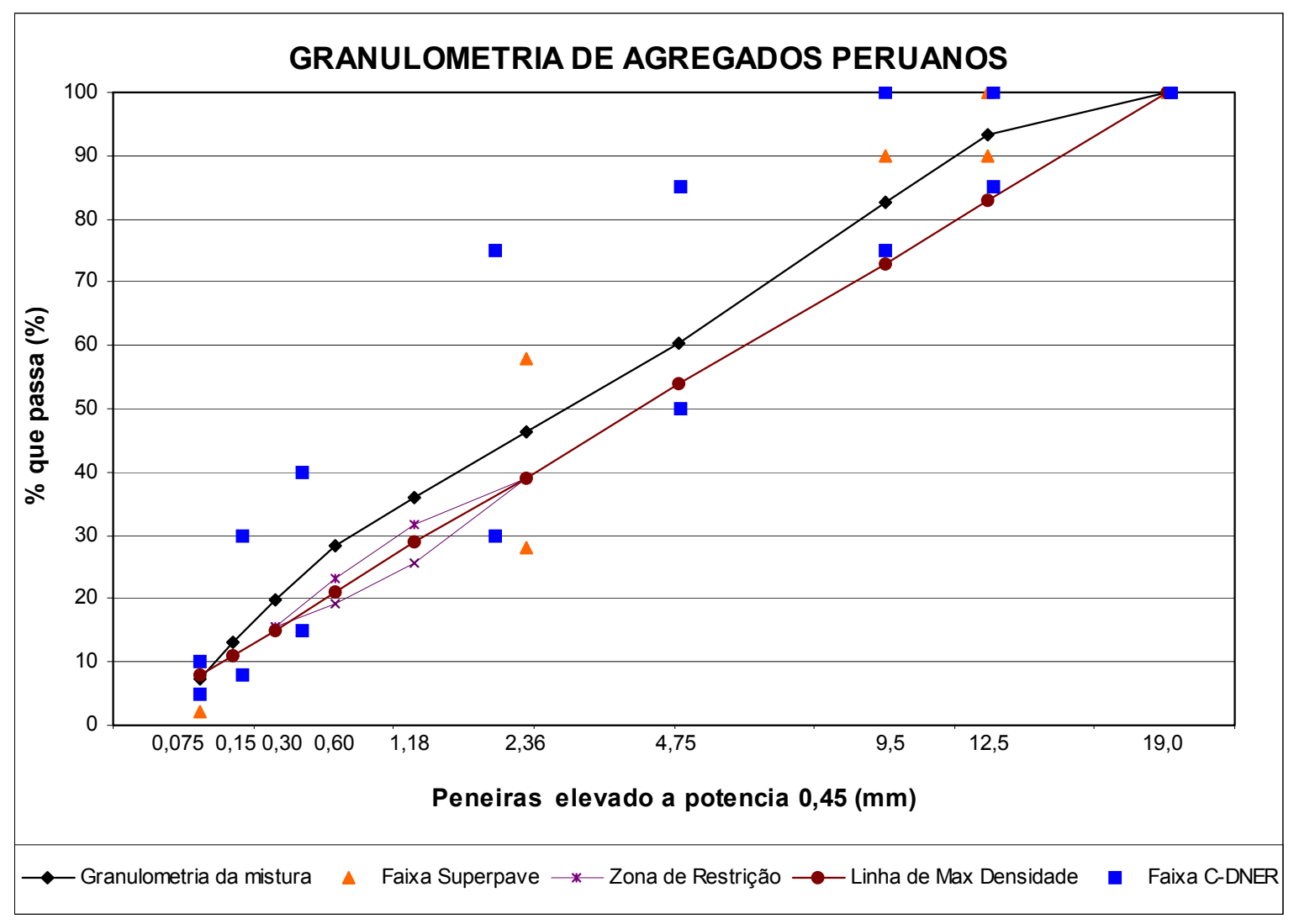

Figura 5.1 - Enquadramento da curva granulométrica da mistura asfáltica escolhida na especificação Superpave e na faixa C do DNER.

\subsubsection{Características físicas e mecânicas}

Tendo em vista que o agregado utilizado nesta pesquisa é proveniente de rocha britada, tem forma cúbica e textura áspera, ele apresenta características adequadas quanto à resistência ao cisalhamento, reduzindo a deformação permanente do pavimento. 
No que diz respeito às propriedades de consenso do Superpave (faces fraturadas; vazios não compactados; equivalente areia; partículas planas e alongadas), o agregado empregado atende aos requisitos para faixa de volume de tráfego elevado. Com relação às exigências das especificações brasileiras, os agregados apresentaram boas características mecânicas: abrasão Los Angeles de $22 \%$, equivalente areia de $87 \%$ e durabilidade sujeitos à ação do tempo, pelo ataque de soluções saturadas de sulfato de sódio de $9,48 \%$ de um máximo de $12 \%$ especificado pela norma DNER-ME-089/94.

\subsection{LIGANTES ASFÁLTICOS}

Foram analisados comparativamente os resultados obtidos com CAP PEN 60/70, AMP SBS Tipo I 60/60 e AMP SBS PG 76 -22, mostrados nas Tabelas 4.3 e 4.4 no que diz respeito a:

- Penetração

- Ponto de Amolecimento

- Índice de Susceptibilidade Térmica.

- Viscosidade

- Retorno Elástico

- Envelhecimento

- Desempenho (deformação permanente e fadiga)

\subsubsection{Penetração}

Os ensaios de penetração em ligantes sem envelhecimento mostraram que os asfaltos modificados são mais duros que o CAP convencional, apresentando uma relação de 
penetração variável em função da viscosidade de cada ligante. A penetração após envelhecimento tem a mesma tendência nos três tipos de ligante asfáltico, devido ao enrijecimento do CAP, porém pode-se observar que os AMP Tipo I 60/60 e PG 76 -22, após envelhecimento no RTFOT, não se tornaram tão rígidos quanto o CAP PEN 60/70, apresentando penetrações retidas de 69 e $64 \%$ respectivamente, enquanto que o CAP PEN 60/70 apresentou uma penetração retida de $47 \%$, mostrando a maior taxa de enrijecimento do CAP convencional em relação aos AMP. A Figura 5.2 apresenta a variação da penetração do ligante sem envelhecimento e após envelhecimento no RTFOT.

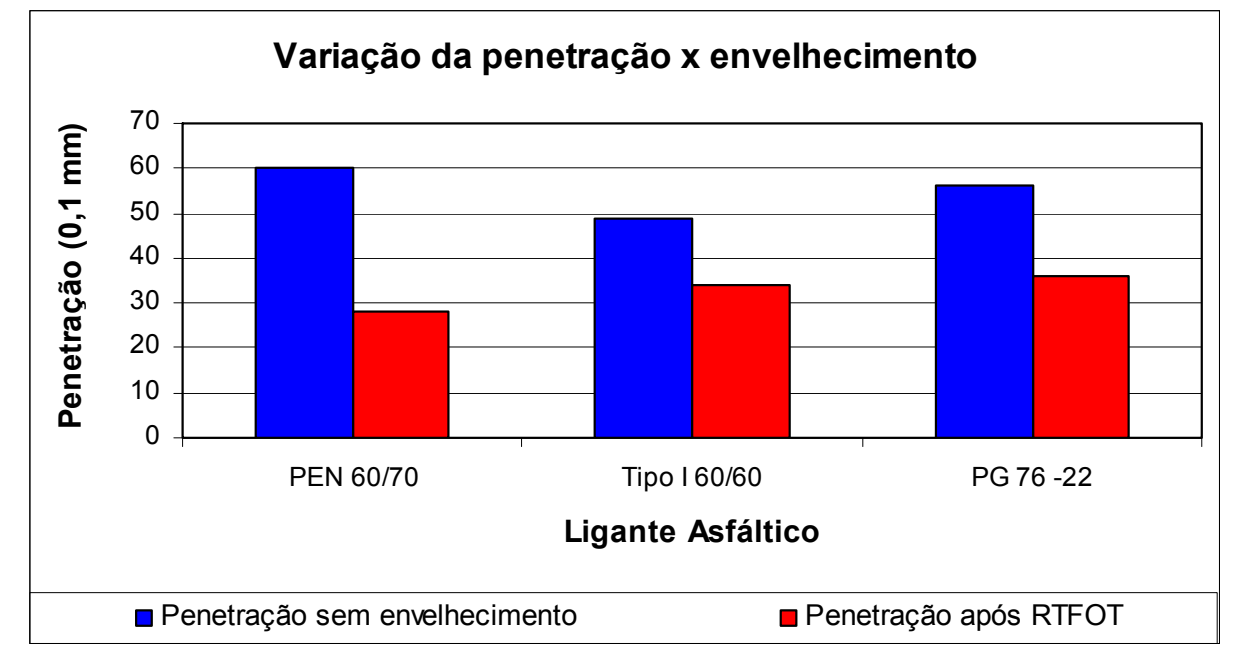

Figura 5.2 - Variação da Penetração em ligante sem envelhecimento e após RTFOT.

\subsubsection{Ponto de Amolecimento}

Os resultados do ensaio de ponto de amolecimento mostraram que os asfaltos modificados por polímero apresentam as maiores temperaturas de ponto de amolecimento, indicando a maior dureza destes. $\mathrm{O}$ aumento da temperatura de amolecimento do material é um fator importante para avaliação do comportamento dos ligantes, fato que pode contribuir para a melhoria do desempenho do asfalto modificado para fins de pavimentação, este parâmetro apresenta uma 
relação com a penetração, já que, quanto maior é o ponto de amolecimento, menor é a penetração.

O ponto de amolecimento após envelhecimento tem a tendência de aumentar devido ao enrijecimento do CAP, mas os AMP Tipo I 60/60 e PG 76 -22, após envelhecimento no RTFOT, não se tornaram tão rígidos quanto o CAP PEN 60/70, apresentando incrementos do ponto de amolecimento de 5 e $6{ }^{\circ} \mathrm{C}$ respectivamente, enquanto que o CAP PEN 60/70 apresentou um incremento de $10{ }^{\circ} \mathrm{C}$, mostrando também a maior taxa de enrijecimento com respeito aos AMP. A Figura 5.3 apresenta a variação do ponto de amolecimento do ligante sem envelhecimento e após envelhecimento no RTFOT.

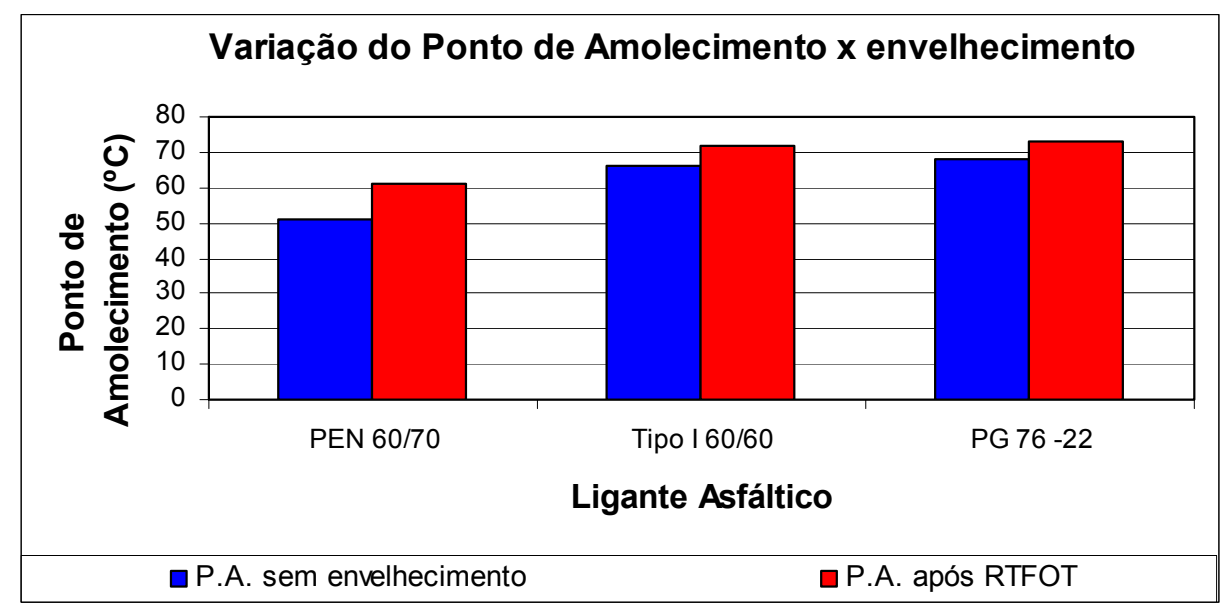

Figura 5.3 - Variação do Ponto de Amolecimento em ligante sem envelhecimento e após RTFOT.

\subsection{3 Índice de Suscetibilidade Térmica}

A partir dos dados de índice de susceptibilidade térmica (IST) para as amostras analisadas, pode-se concluir que: 
O asfalto convencional PEN 60/70 apresenta um índice de susceptibilidade térmica de $-0,5$, compreendido na faixa de $-1,5 \mathrm{a}+0,7$ especificada pelas normas brasileiras para asfalto PEN 50-70, e na faixa de -2 e +2 que corresponde a amostras asfálticas que apresentam elasticidade, sendo denominados tipo sol ou betumes normais, que são apropriados aos serviços de pavimentação (SENÇO, 1997).

Os AMP Tipo I 60/60 e PG 76 -22 apresentam índices de susceptibilidade térmica de 2,1 e 2,8 respectivamente. Valores maiores que +2 correspondem a asfaltos pouco susceptíveis e que apresentam elasticidade, enquanto valores menores do que -2 são relacionados a asfaltos muito susceptíveis e com comportamento viscoso. Dos resultados pode-se concluir que os AMP apresentam elasticidade e são pouco susceptíveis, além de respeitarem os parâmetros especificados pela norma DNER-EM-396/99.

O índice de susceptibilidade térmica dos ligantes asfálticos também sofre variação com o envelhecimento, o que está relacionado com as variações sofridas nos ensaios de penetração e ponto de amolecimento após RTFOT. Na Figura 5.4 apresenta-se a variação do índice de susceptibilidade térmica do ligante sem envelhecimento e após envelhecimento no RTFOT.

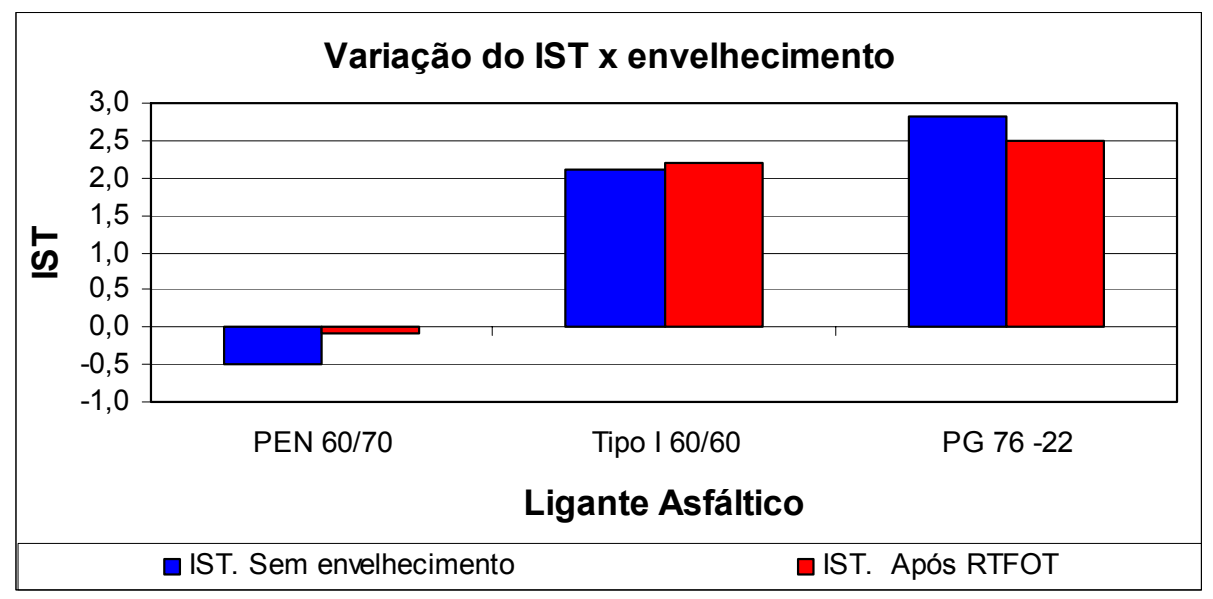

Figura 5.4 - Variação do IST em ligante sem envelhecimento e após RTFOT. 


\subsubsection{Viscosidade}

Os ensaios de viscosidade Brookfield mostraram que os asfaltos modificados por polímeros apresentam viscosidade a $135^{\circ} \mathrm{C}$ dentro dos limites especificados pelo Superpave (máximo $3.000 \mathrm{cP})$.

Da análise dos resultados de viscosidade Brookfield dos três ligantes asfálticos utilizados na pesquisa se observou que as curvas de viscosidade sem envelhecimento e após RTFOT do CAP PEN 60/70 e do AMP Tipo I 60/60 são praticamente paralelas. No caso do AMP PG 76 -22 as curvas de viscosidade têm menor inclinação, o que representa uma menor taxa de variação da viscosidade com a temperatura, desta forma este ligante asfáltico apresentou as maiores temperaturas de usinagem e compactação, embora não tenha apresentado a viscosidade mais elevada a $135^{\circ} \mathrm{C}$. Nas Figuras 5.5, 5.6 e 5.7 podem-se verificar as variações das viscosidades dos ligantes asfálticos sem envelhecimento e após envelhecimento no RTFOT dos três ligantes asfálticos.

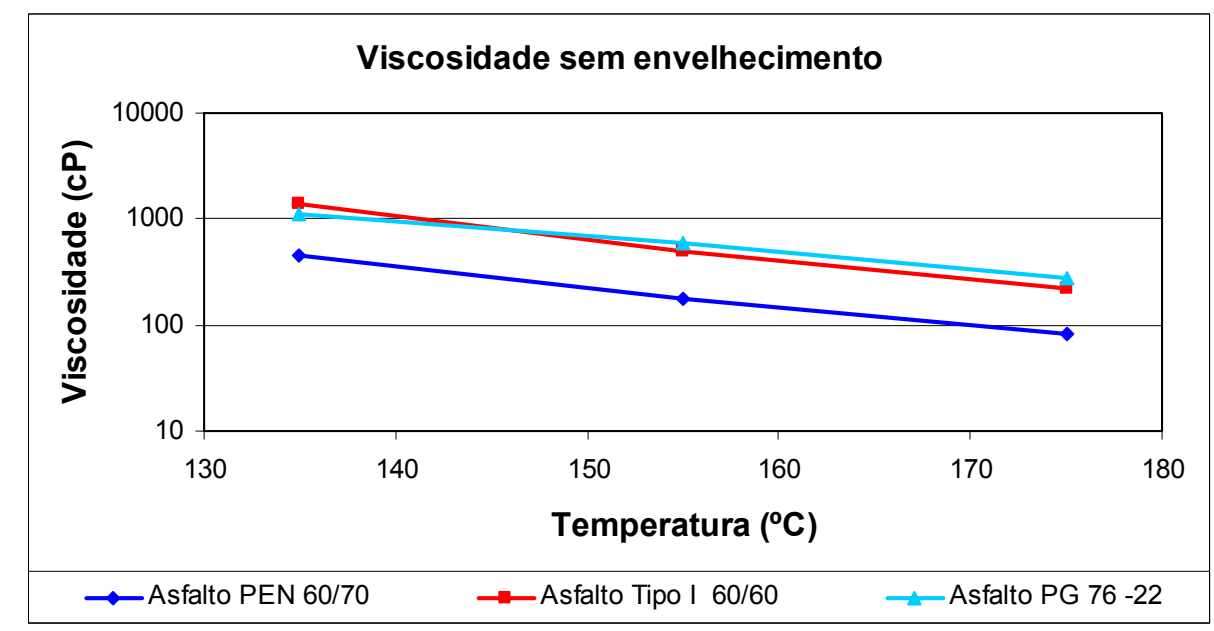

Figura 5.5 - Viscosidade sem envelhecimento dos ligantes asfálticos utilizados na pesquisa. 


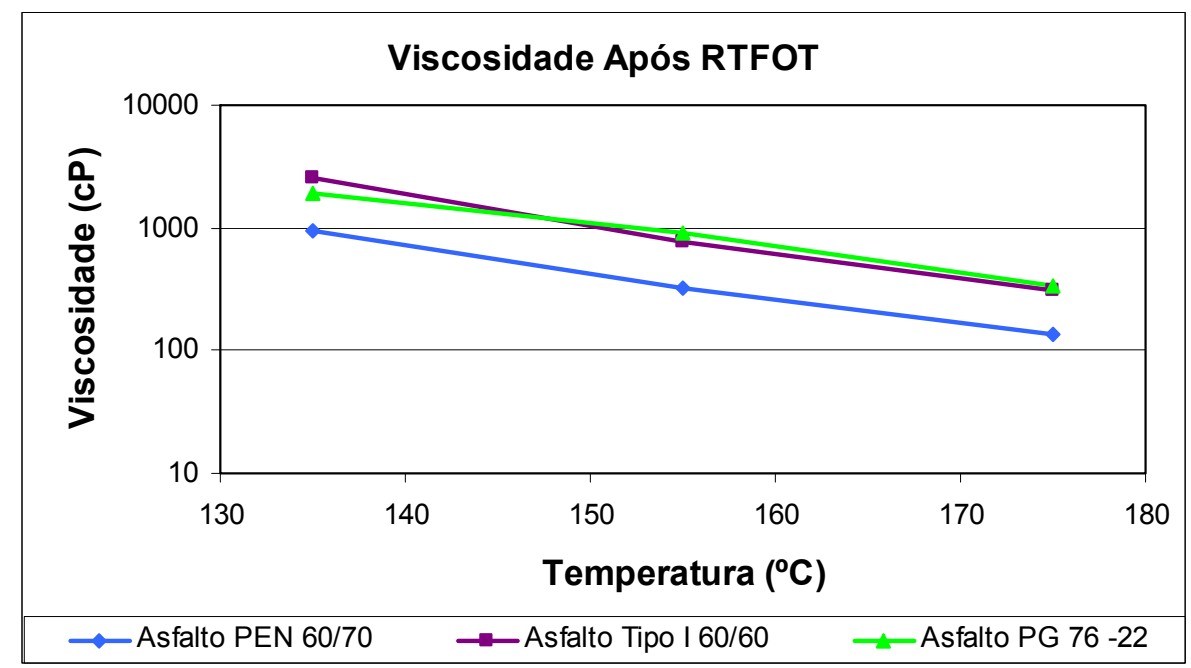

Figura 5.6 - Viscosidade após RTFOT dos ligantes asfálticos utilizados na pesquisa.

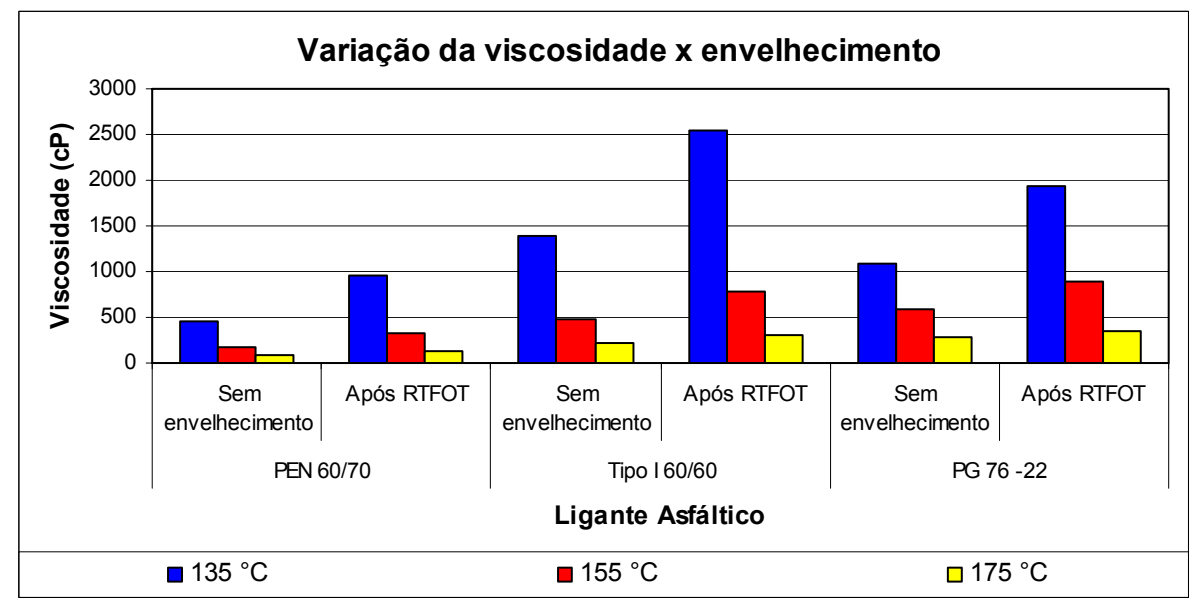

Figura 5.7 - Variação da viscosidade em ligante sem envelhecimento e após RTFOT.

\subsubsection{Retorno Elástico}

Os ensaios de Retorno Elástico foram unicamente realizados nos AMP, em ligante sem envelhecimento e após envelhecimento no RTFOT e mostraram que o AMP PG 76 -22 tem um maior retorno elástico tanto em ligante sem envelhecimento como após envelhecimento no RTFOT, além de apresentar um maior retorno elástico retido (Figura 5.8). 


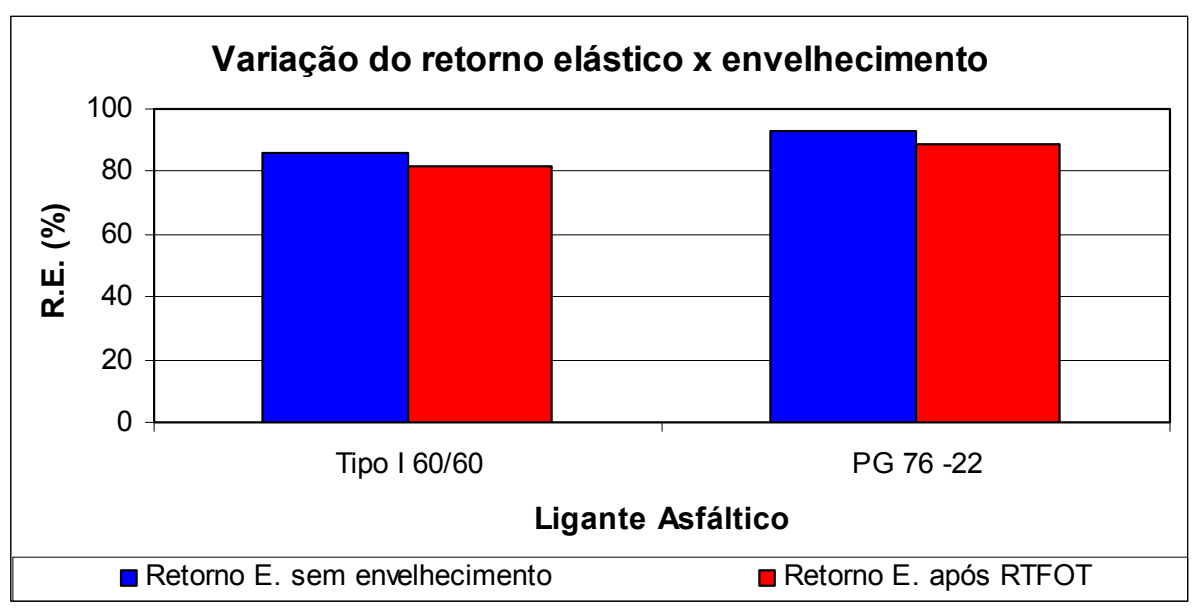

Figura 5.8 - Variação do retorno elástico em ligante sem envelhecimento e após RTFOT.

\subsubsection{Envelhecimento}

Os ligantes asfálticos modificados por polímero geralmente apresentam boas características quanto à resistência ao envelhecimento. Esse comportamento deve estar ligado provavelmente ao baixo teor de frações aromáticas, voláteis e maltênicas, que dão aos asfaltos modificados uma perspectiva de desempenho mais constante ao longo de sua vida de serviço. Como pode ser observado nas figuras 5.2 e 5.3, após envelhecimento no RTFOT, os asfaltos modificados apresentaram pouca variação na penetração (69 e 64\% de penetração retida) e no ponto de amolecimento $\left(6\right.$ e $\left.7^{\circ} \mathrm{C}\right)$, diferentemente do ligante convencional, que teve uma penetração retida de $47 \%$ e variação na temperatura do ponto de amolecimento de $10^{\circ} \mathrm{C}$. De modo geral, os resultados deste trabalho confirmaram que os asfaltos modificados apresentam boa resistência ao envelhecimento.

\subsubsection{Efeito do ligante no desempenho da mistura}

O PG do ligante asfáltico encontra-se diretamente relacionado com o desempenho das misturas asfálticas, (deformação permanente, trincas por baixas temperaturas e vida de 
fadiga), e como foi visto no Capítulo 3, cada região necessita de um ligante com grau de desempenho capaz de atender suas condições meteorológicas e de tráfego.

O PG a altas temperaturas dos asfaltos modificados estudados $\left(76^{\circ} \mathrm{C}\right)$ foi superior ao $\mathrm{PG}$ do ligante convencional $\left(64^{\circ} \mathrm{C}\right)$, significando que os AMP têm boa resistência à deformação permanente até temperaturas de $76{ }^{\circ} \mathrm{C}$, o que permite concluir que por meio do processo de modificação se obteve um ganho no desempenho a altas temperaturas (maior resistência à deformação permanente) de 2 níveis da classificação Superpave. Esse salto no desempenho qualifica, a princípio, esses materiais para uso nas regiões mais quentes da costa e selva peruana, que requerem esse PG obtido, mesmo considerando alto volume de tráfego e engarrafamento, situação para a qual o Superpave recomenda um aumento do PG para compensar o tráfego lento.

No caso do desempenho a baixas temperaturas, tanto os asfaltos modificados por polímeros quanto o asfalto convencional têm a propriedade de resistir ao trincamento térmico até temperaturas de $-22^{\circ} \mathrm{C}$ o que qualifica o desempenho desses materiais para uso nas regiões mais frias da Serra peruana.

Pode-se concluir que os dois asfaltos modificados por polímeros avaliados neste trabalho são capazes de atender às condições meteorológicas e de tráfego mais críticas do estado peruano, porém o CAP convencional PEN 60/70 não consegue atender às solicitações climáticas das regiões mais quentes da costa e selva do Peru. Na Figura 5.9 são apresentados os graus de desempenho PG dos ligantes asfálticos utilizados nesta pesquisa. 


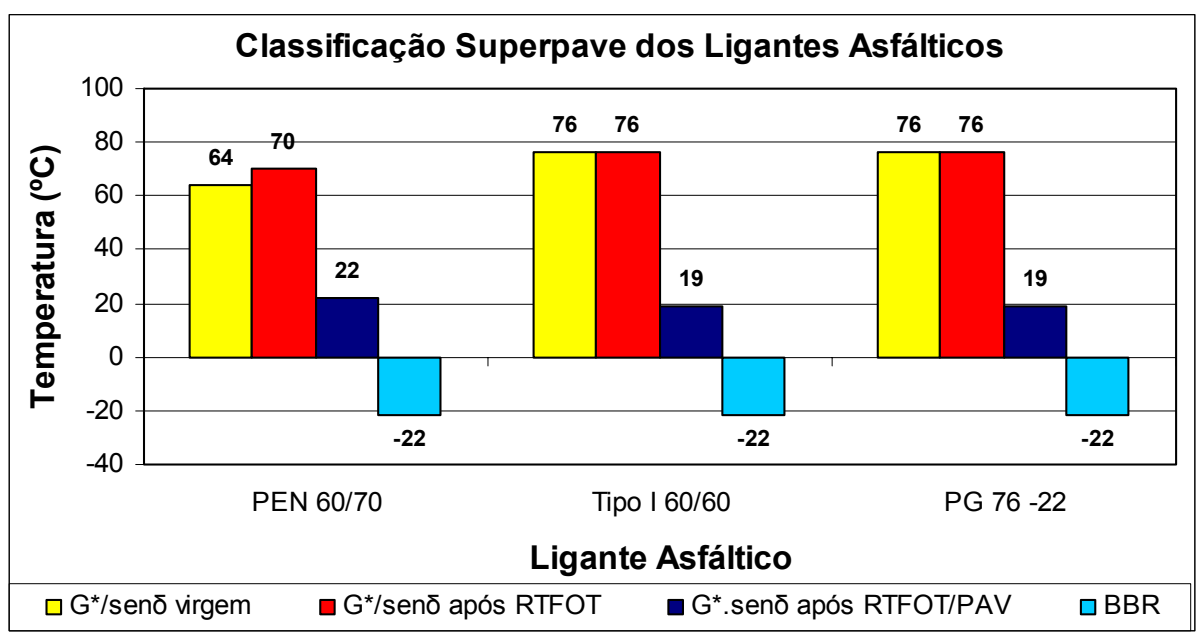

Figura 5.9 - Classificação Superpave dos ligantes asfálticos utilizados na pesquisa.

\subsection{MISTURAS ASFÁLTICAS}

A análise do comportamento mecânico das misturas asfálticas foi realizada a partir das seguintes características:

- avaliação da rigidez da mistura, traduzida nos valores dos módulos de resiliência (MR) e da resistência à tração $(\mathrm{RT})$;

- avaliação da resistência à deformação permanente, traduzida nos resultados dos ensaios de fluência por compressão uniaxial estática e dinâmica;

- avaliação da vida de fadiga, traduzida nas curvas de fadiga.

\subsubsection{Estimativa do teor de projeto dos ligantes asfálticos}

Os teores de projeto de ligante asfáltico foram obtidos em duas condições, sem envelhecimento (DNER-ME 043/95) e com envelhecimento em curto prazo de 2 horas na 
estufa (ASTM D 6926/04) levando em consideração um volume de vazios de 4\%, conforme recomendado pelo Superpave.

Os teores de projeto obtidos para misturas sem envelhecimento foram de 5,08\% para o CAP PEN 60/70, 5,10\% para o AMP Tipo I 60/60 e 5,12\% para o AMP PG 76 -22, os quais podem ser observados nas Figuras 5.10, 5.11 e 5.12 respectivamente. Assim foi adotado um teor de projeto de $5,1 \%$ para todos os tipos de ligante asfáltico.

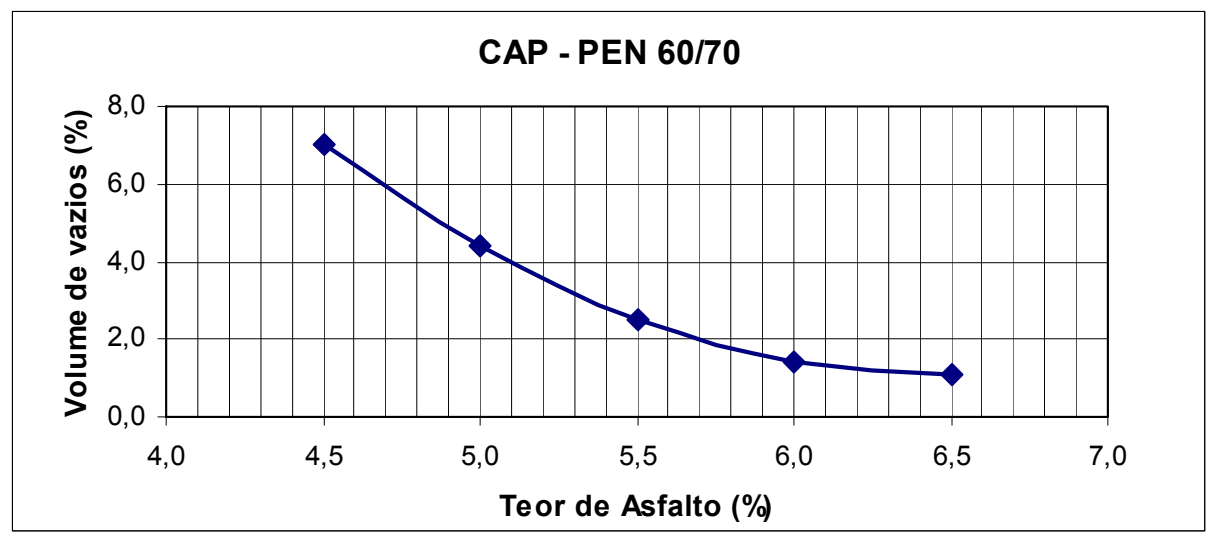

Figura 5.10 - Teor de projeto sem envelhecimento - CAP PEN 60/70.

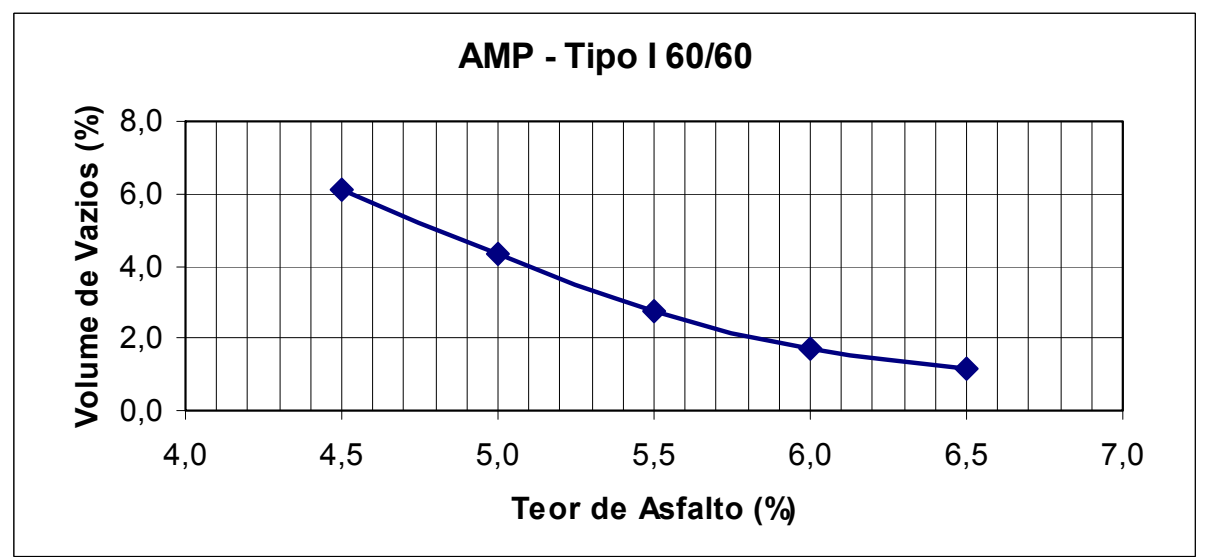

Figura 5.11 - Teor de projeto sem envelhecimento - AMP Tipo I 60/60. 


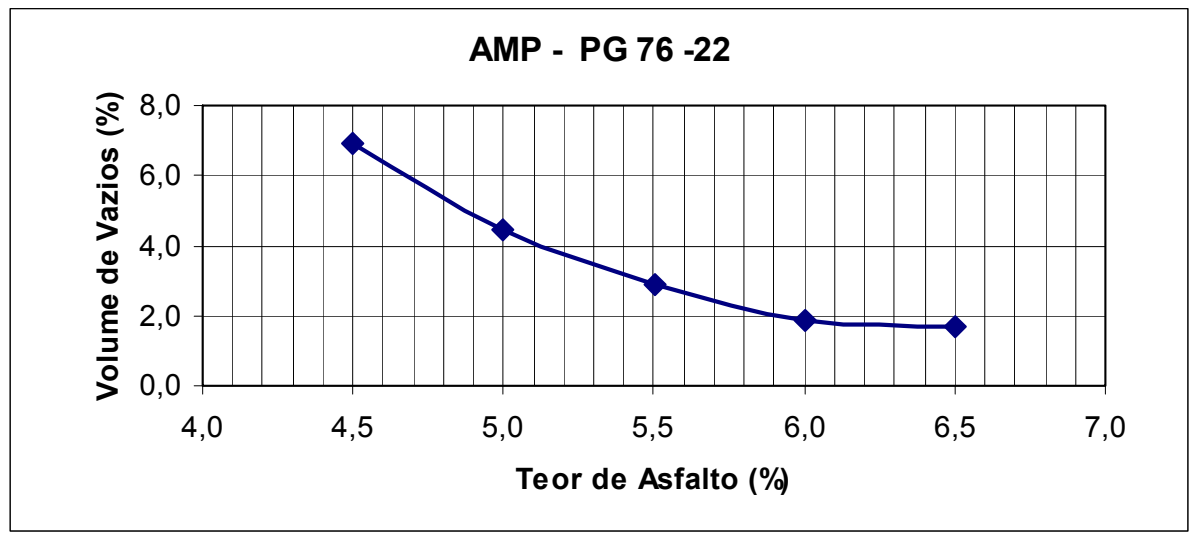

Figura 5.12 - Teor de projeto sem envelhecimento - AMP PG 76 -22.

Os teores de projeto obtidos para misturas com envelhecimento em curto prazo ( $2 \mathrm{~h}$ na estufa) foram de 5,76\% para o CAP PEN 60/70, 5,79\% para o AMP Tipo I 60/60 e 5,82\% para o AMP PG 76 -22, os quais se observam nas Figuras 5.13, 5.14 e 5.15, respectivamente. Dessa forma, foi assumido um teor de projeto de 5,8\% para todos os tipos de ligante asfáltico.

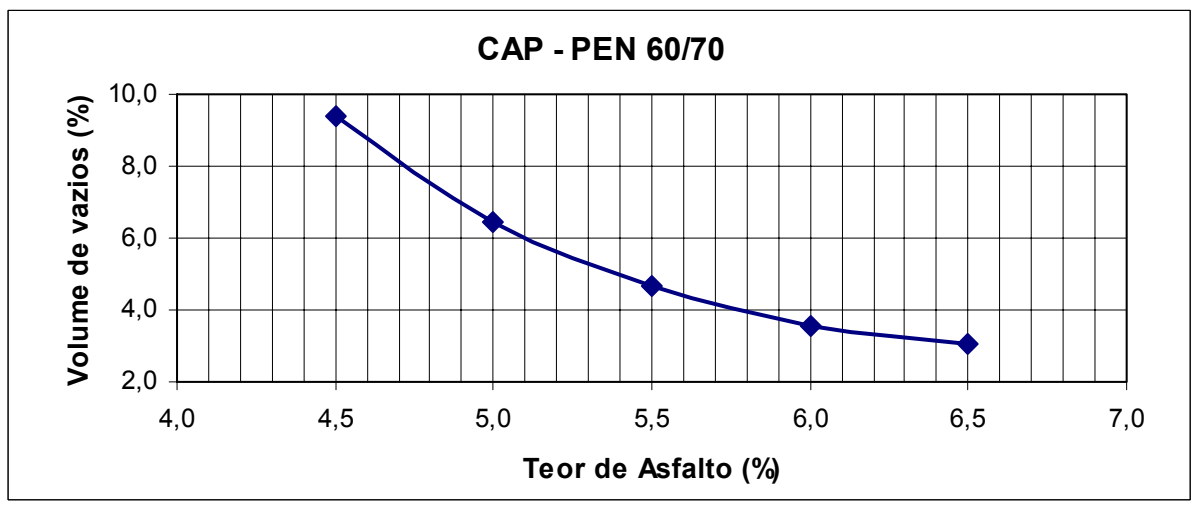

Figura 5.13 - Teor de projeto com envelhecimento em curto prazo - CAP PEN 60/70. 


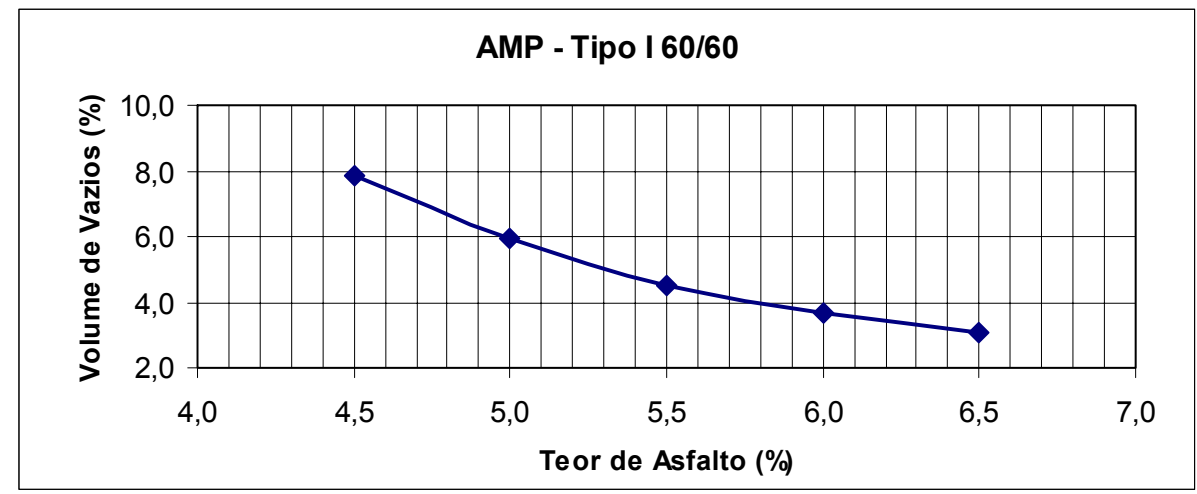

Figura 5.14 - Teor de projeto com envelhecimento em curto prazo - AMP Tipo I 60/60.

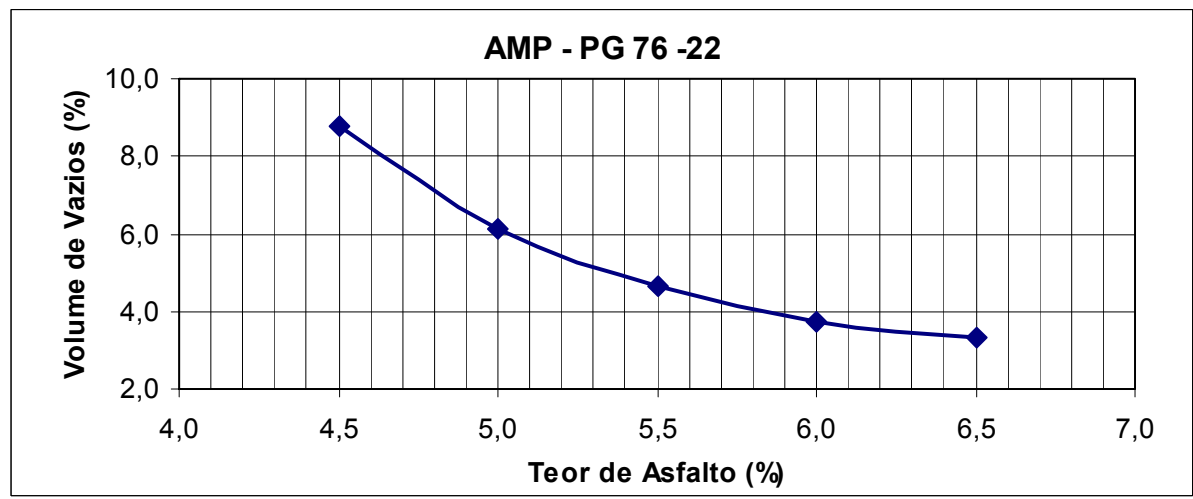

Figura 5.15 - Teor de projeto com envelhecimento em curto prazo - AMP PG 76 -22.

Os resultados obtidos da dosagem Marshall, em misturas sem envelhecimento e com envelhecimento em curto prazo, encontram-se dentro dos parâmetros especificados nas normas DNER-ES 313/97 para CAP e DNER-ES 385/99 para AMP e nos parâmetros do Superpave especificados pela AASHTO MP2.

\subsubsection{Estimativa da densidade máxima teórica (Método Rice)}

Foram realizados 15 ensaios Rice na etapa de dosagem. Posteriormente, foram determinadas as densidades máximas teóricas $(\mathrm{Gmm})$ para o teor de projeto e condição de envelhecimento de cada tipo de ligante asfáltico utilizado na pesquisa, cujos resultados são apresentados na 
Tabela 5.1. Estes resultados serviram para a determinação da absorção dos ligantes asfálticos nas condições de 2 e 4 horas de envelhecimento, determinando-se que a absorção para 2 e 4 horas de envelhecimento foi a mesma, sendo assim determinados os teores de projeto para todas as condições de envelhecimento.

Tabela 5.1 - Resultados do ensaio de densidade máxima teórica da mistura.

\begin{tabular}{lc}
\hline \multicolumn{1}{c}{ Mistura } & $\begin{array}{c}\text { Densidade Máxima } \\
\text { Teórica (Gmm) }\end{array}$ \\
\hline Mistura com CAP PEN 60/70, com 2 h de envelhecimento & 2,608 \\
Mistura com CAP PEN 60/70, com 4 h de envelhecimento & 2,609 \\
Mistura com AMP Tipo I, com 2 h de envelhecimento & 2,606 \\
Mistura com AMP Tipo I, com 4 h de envelhecimento & 2,604 \\
Mistura com AMP PG 76 -22 com 2 h de envelhecimento & 2,606 \\
Mistura com AMP PG 76 -22 com 4 h de envelhecimento & 2,607 \\
\hline
\end{tabular}

\subsubsection{Ensaio de estabilidade e fluência Marshall}

\subsubsection{Ensaios de Estabilidade e Fluência Marshall para misturas sem envelhecimento}

As tabelas 5.2, 5.3 e 5.4 apresentam os resultados das médias da densidade aparente (d), densidade máxima teórica (DTM), volume de vazios (Vv), relação betume/vazios (RBV), estabilidade (E), fluência (F) e capacidade de suporte Marshall (CSM) para misturas sem envelhecimento, com CAP PEN 60/70, AMP Tipo I 60/60 e PG 76 -22 respectivamente. 
Tabela 5.2 - Resultados volumétricos e de estabilidade e fluência Marshall - CAP PEN 60/70 sem envelhecimento.

\begin{tabular}{ccccccccc}
\hline $\begin{array}{c}\text { T. de Asfalto } \\
(\%)\end{array}$ & $\begin{array}{c}\text { Dens. Ap } \\
\text { (d) }\end{array}$ & DTM & $\begin{array}{c}\text { Vv } \\
(\mathbf{\%})\end{array}$ & $\begin{array}{c}\text { VAM } \\
\mathbf{( \% )}\end{array}$ & $\begin{array}{c}\text { RBV } \\
(\mathbf{\%})\end{array}$ & $\begin{array}{c}\text { Estabilidade } \\
(\mathbf{N})\end{array}$ & $\begin{array}{c}\text { Fluência } \\
(\mathbf{m m})\end{array}$ & $\begin{array}{c}\text { CSM } \\
\mathbf{( N / m m )}\end{array}$ \\
\hline 4,5 & 2,480 & 2,667 & 7,0 & 17,98 & 60,91 & 16645 & 3,56 & 4681 \\
5,0 & 2,529 & 2,645 & 4,4 & 16,80 & 73,86 & 16072 & 3,68 & 4364 \\
5,5 & 2,557 & 2,623 & 2,5 & 16,32 & 84,55 & 16015 & 3,94 & 4068 \\
6,0 & 2,565 & 2,601 & 1,4 & 16,51 & 91,47 & 15299 & 4,06 & 3764 \\
6,5 & 2,552 & 2,580 & 1,1 & 17,36 & 93,81 & 14464 & 4,19 & 3451 \\
\hline
\end{tabular}

Tabela 5.3 - Resultados volumétricos e de estabilidade e fluência Marshall - AMP Tipo I 60/60 sem envelhecimento.

\begin{tabular}{|c|c|c|c|c|c|c|c|c|}
\hline $\begin{array}{c}\text { T. de Asfalto } \\
\text { (\%) }\end{array}$ & $\begin{array}{c}\text { Dens. Ap } \\
\text { (d) }\end{array}$ & DTM & $\begin{array}{l}\text { Vv } \\
(\%)\end{array}$ & $\begin{array}{c}\text { VAM } \\
(\%)\end{array}$ & $\begin{array}{l}\text { RBV } \\
(\%)\end{array}$ & $\begin{array}{c}\text { Estabilidade } \\
\text { (N) }\end{array}$ & $\begin{array}{l}\text { Fluência } \\
\text { (mm) }\end{array}$ & $\begin{array}{c}\text { CSM } \\
(\mathrm{N} / \mathrm{mm})\end{array}$ \\
\hline 4,5 & 2,502 & 2,665 & 6,1 & 17,26 & 64,45 & 23367 & 3,05 & 7666 \\
\hline 5,0 & 2,528 & 2,643 & 4,3 & 16,82 & 74,27 & 22795 & 3,18 & 7180 \\
\hline 5,5 & 2,549 & 2,620 & 2,7 & 16,58 & 83,53 & 21713 & 3,43 & 6332 \\
\hline 6,0 & 2,554 & 2,599 & 1,7 & 16,84 & 89,91 & 20314 & 3,94 & 5160 \\
\hline 6,5 & 2,547 & 2,577 & 1,2 & 17,52 & 93,38 & 19251 & 4,19 & 4594 \\
\hline
\end{tabular}

Tabela 5.4 - Resultados volumétricos e de estabilidade e fluência Marshall - AMP PG 76 -22 sem envelhecimento.

\begin{tabular}{ccccccccc}
\hline $\begin{array}{c}\text { T. de Asfalto } \\
(\%)\end{array}$ & $\begin{array}{c}\text { Dens. Ap } \\
\mathbf{( d )}\end{array}$ & DTM & $\begin{array}{c}\text { Vv } \\
\mathbf{( \% )}\end{array}$ & $\begin{array}{c}\text { VAM } \\
\mathbf{( \% )}\end{array}$ & $\begin{array}{c}\text { RBV } \\
(\mathbf{\%})\end{array}$ & $\begin{array}{c}\text { Estabilidade } \\
\mathbf{( N )}\end{array}$ & $\begin{array}{c}\text { Fluência } \\
(\mathbf{m m})\end{array}$ & $\begin{array}{c}\text { CSM } \\
\mathbf{( N / m m )}\end{array}$ \\
\hline 4,5 & 2,481 & 2,665 & 6,9 & 17,95 & 61,47 & 22478 & 3,05 & 7375 \\
5,0 & 2,525 & 2,643 & 4,4 & 16,92 & 73,73 & 22023 & 3,43 & 6423 \\
5,5 & 2,544 & 2,620 & 2,9 & 16,74 & 82,61 & 21890 & 3,68 & 5943 \\
6,0 & 2,551 & 2,599 & 1,8 & 16,96 & 89,16 & 19076 & 4,06 & 4694 \\
6,5 & 2,533 & 2,577 & 1,7 & 17,97 & 90,53 & 17103 & 4,19 & 4081 \\
\hline
\end{tabular}

Na Figura 5.16 é apresentado o gráfico das variações das densidades aparentes das misturas em função dos teores de ligante. Os valores encontrados para as densidades aparentes, nos teores de projeto sem envelhecimento, para os três tipos de ligantes, foram: 2,536 para o CAP PEN 60/70, 2,533 para o AMP Tipo I 60/60 e 2,531 para o AMP PG 76 -22. Observa-se que 
as densidades aparentes encontradas para o teor de projeto sem envelhecimento foram bem próximas, tendo diferença só na terceira casa decimal.

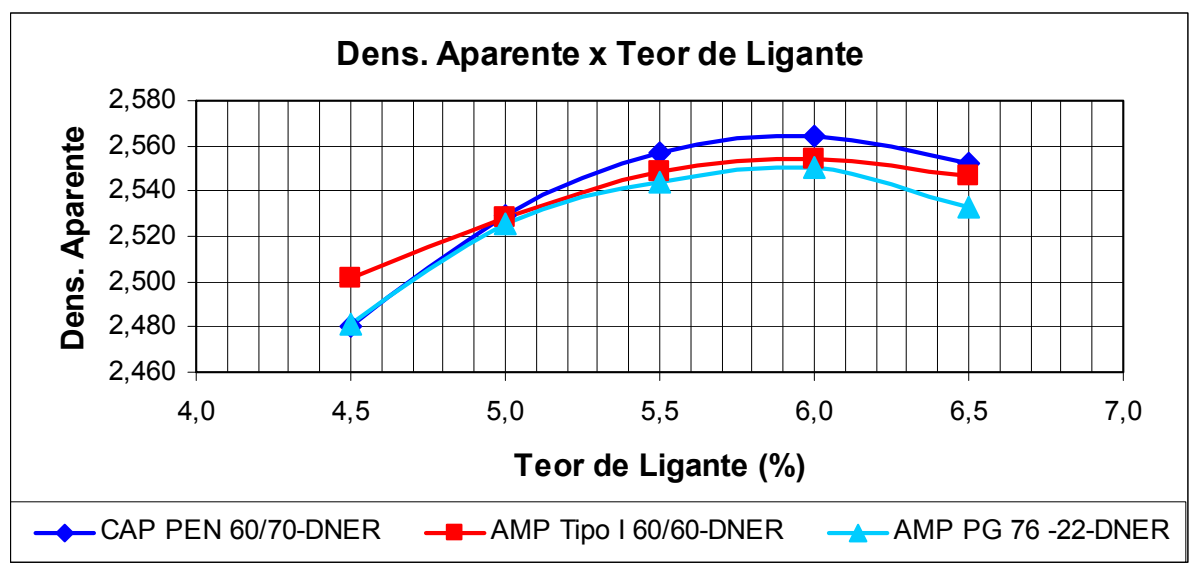

Figura 5.16 - Valores médios da densidade aparente das três misturas.

Na Figura 5.17 é apresentado o gráfico das variações das densidades máximas teóricas (DTM) das três misturas em função dos teores de ligante. As curvas da DTM encontram-se praticamente superpostas, sendo que a DTM media das três misturas, para o teor de projeto sem envelhecimento, foi de 2,640.

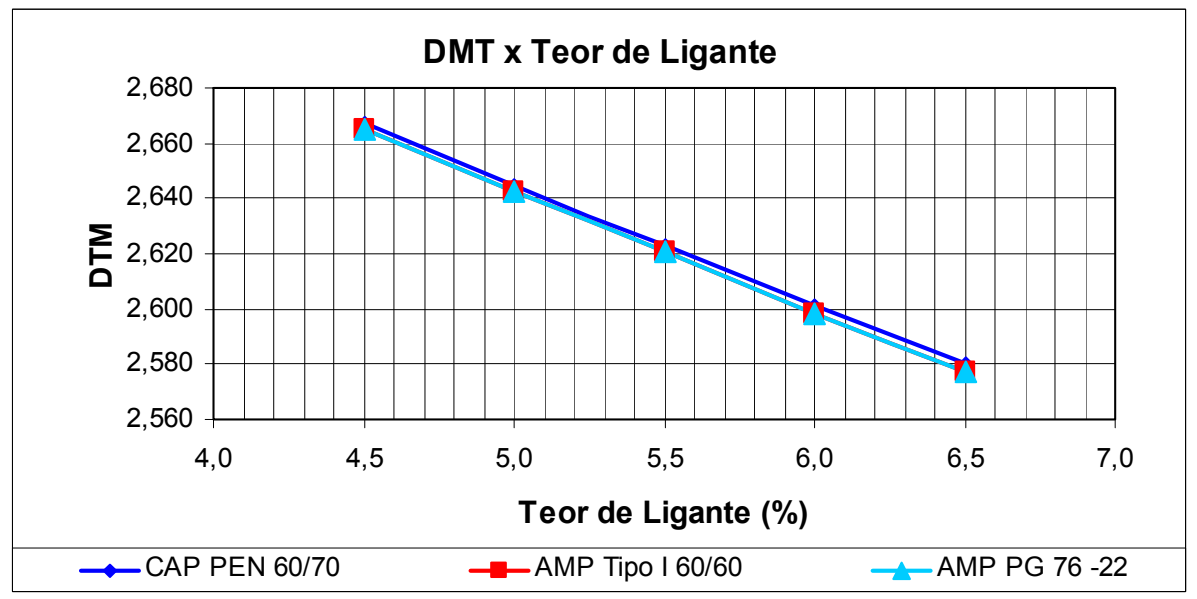

Figura 5.17 - Valores médios da densidade máxima teórica das três misturas. 
Na Figura 5.18 é apresentado o conjunto de curvas de variação dos teores de ligante em função do volume de vazios, para as três misturas estudadas. As curvas são decrescentes com formas semelhantes, com valores de teores de ligante similares para todos os asfaltos, apresentando um teor de projeto de 5,1\%.

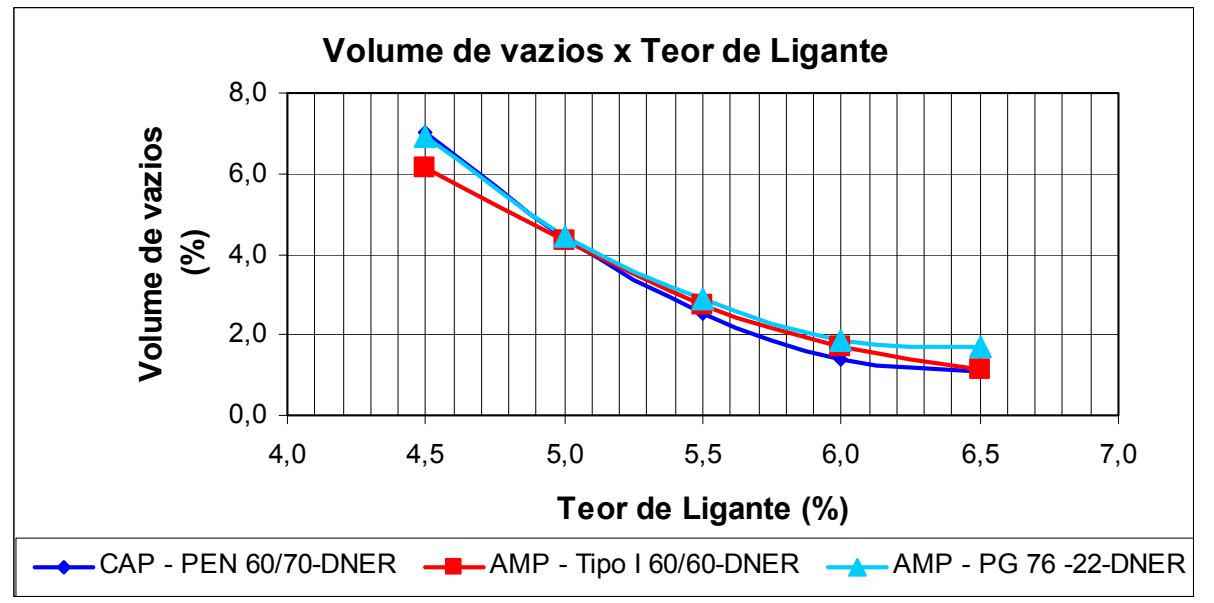

Figura 5.18 - Variação do volume de vazios em função do teor de ligante.

Na Figura 5.19 é apresentado as variações dos Vazios do Agregado Mineral em função do teor de ligante das três misturas. Os VAM encontrados, nos teores de projeto sem envelhecimento, foram: 16,65 para o CAP PEN 60/70, 16,73 para o AMP Tipo I 60/60 e 16,82 para o AMP PG 76 -22, verificando-se os maiores valores de VAM para a mistura com AMP PG $76-22$.

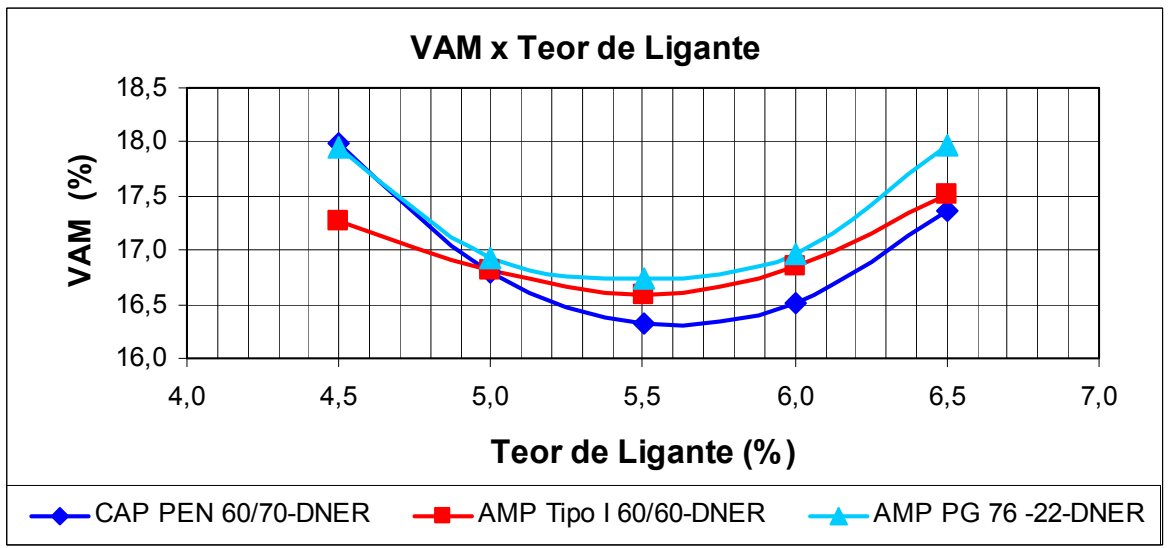

Figura 5.19 - Variação do VAM em função do teor de ligante. 
Na Figura 5.20 é apresentado o gráfico com as variações da Relação Betume Vazios das três misturas, na qual se observa uma superposição das curvas das três misturas, tendo-se RBV médio de 76 para o teor de projeto, para os três asfaltos utilizados.

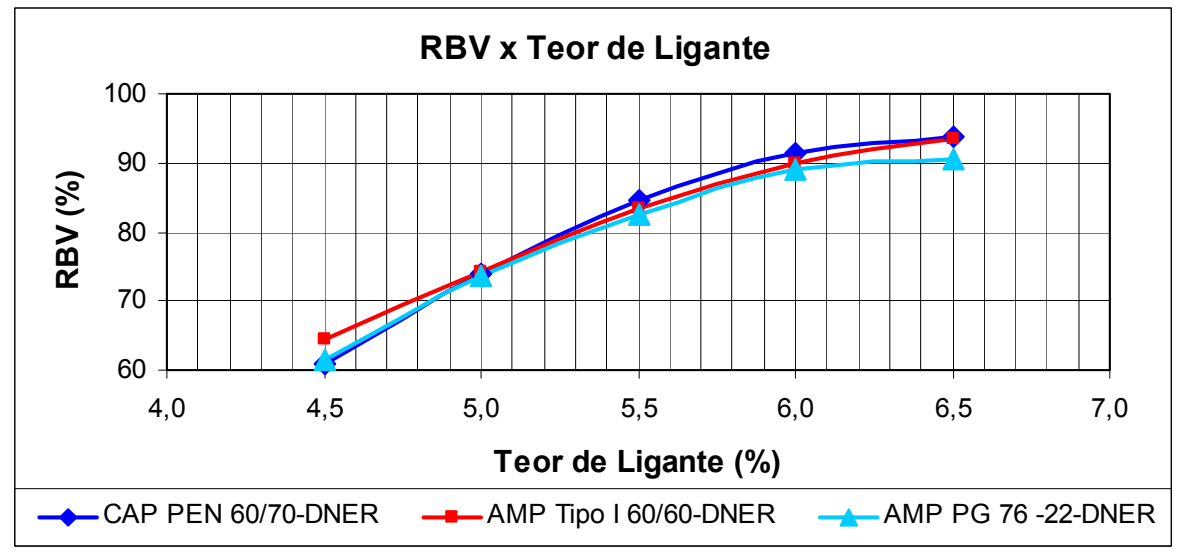

Figura 5.20 - Valores médios da RBV em função do teor de ligante.

Na Figura 5.21 é apresentado o gráfico com os valores das Estabilidades Marshall para as três misturas, verificando-se que o valor máximo de estabilidade para o teor de projeto de $5,1 \%$ foi de 22600 N, obtida com o AMP Tipo I 60/60, seguida pelo AMP PG 76 -22 com 22000 N e o CAP PEN 60/70, que atingiu o menor valor de estabilidade Marshall, com 16000 N. Pode-se concluir pelos resultados obtidos, embora restrito para um pequeno número de amostras, que os asfaltos modificados por polímeros apresentam maiores valores de estabilidade Marshall.

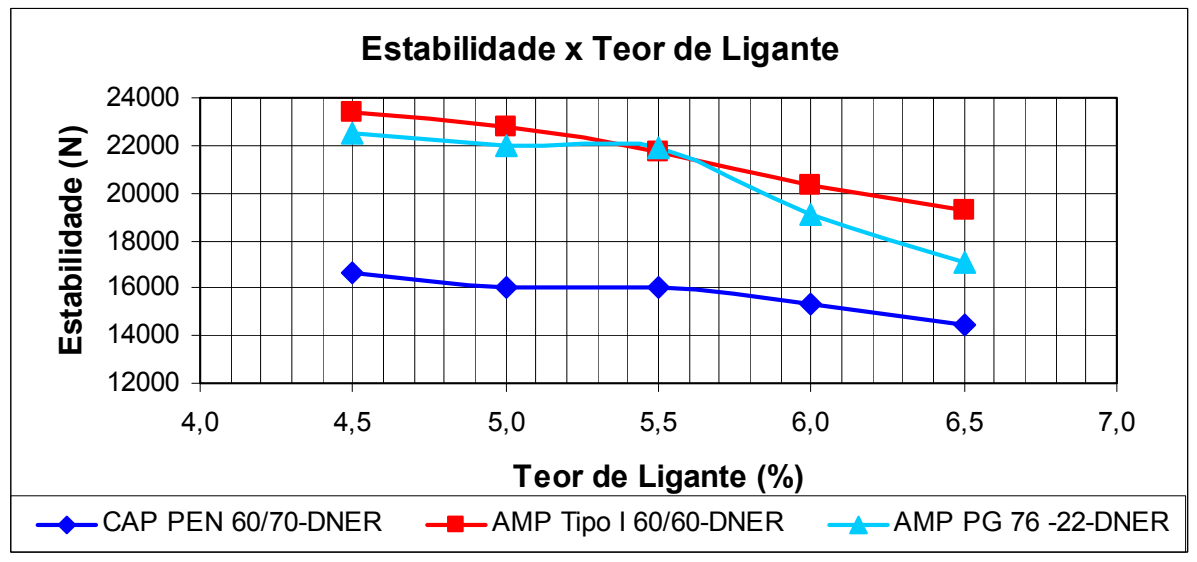

Figura 5.21 - Valores médios das estabilidades Marshall em função do teor de ligante. 
Na Figura 5.22 são apresentadas as curvas de Fluências Marshall para as três misturas. Verifica-se que, a maior fluência foi observada com o CAP PEN 60/70, enquanto os AMP apresentaram menores valores de fluência.

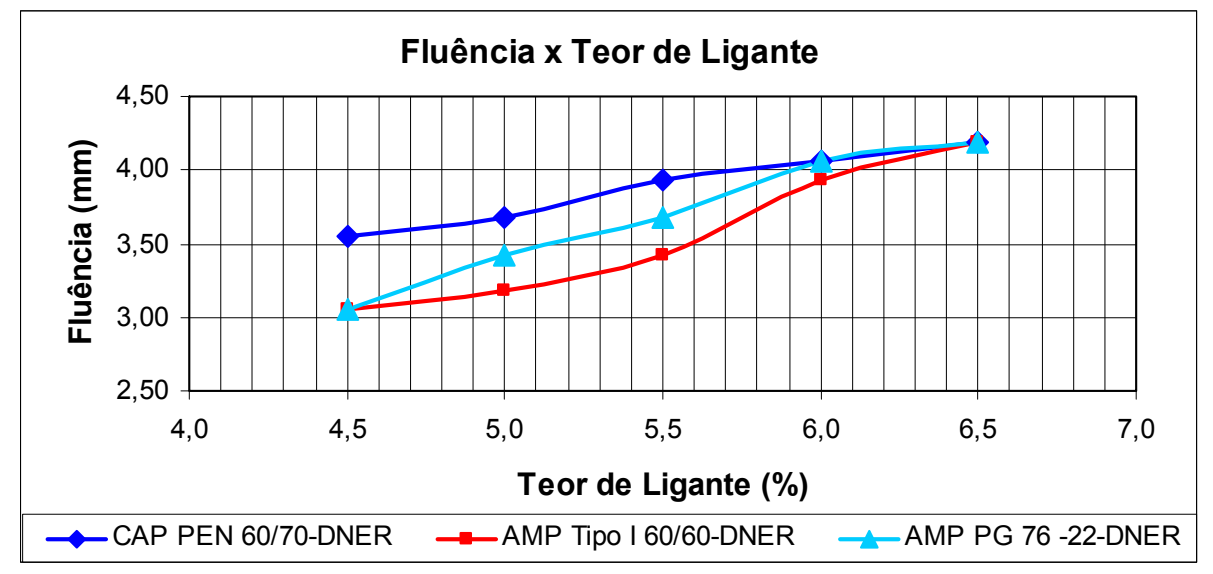

Figura 5.22 - Valores médios das fluências Marshall das três misturas.

Na Figura 5.23 são apresentadas as curvas da capacidade de suporte Marshall, em que o maior valor de CSM, igual a $7000 \mathrm{~N} / \mathrm{mm}$, foi apresentado pelo AMP Tipo I 60/60. O AMP PG 76 22 apresentou um CSM de 6350 N/mm e o CAP PEN 60/70 apresentou o menor valor de CSM igual a $4350 \mathrm{~N} / \mathrm{mm}$. Pode-se observar também que as curvas de CSM dos AMP apresentaram o mesmo formato.

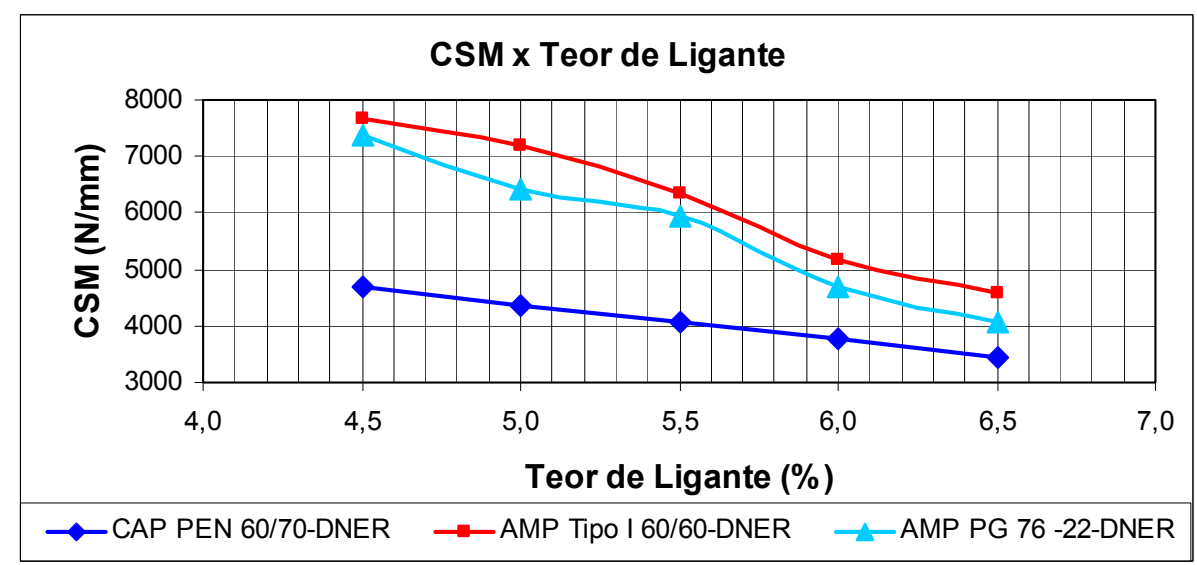

Figura 5.23 - Valores médios da capacidade de suporte Marshall das três misturas. 


\subsubsection{Ensaios de Estabilidade e Fluência Marshall para misturas com envelhecimento em curto prazo}

As Tabelas 5.5, 5.6 e 5.7 apresentam os resultados das médias da densidade aparente (d), densidade máxima teórica determinado através do ensaio Rice $(\mathrm{Gmm})$, volume de vazios $(\mathrm{Vv})$, relação betume/vazios (RBV), estabilidade $(\mathrm{E})$, fluência $(\mathrm{F})$ e capacidade de suporte Marshall (CSM), com envelhecimento em curto prazo das misturas com CAP PEN 60/70 e das misturas com AMP Tipo I 60/60 e PG 76 -22 respectivamente.

Tabela 5.5 - Resultados volumétricos e de estabilidade e fluência Marshall - CAP PEN 60/70 com envelhecimento.

\begin{tabular}{ccccccccc}
\hline $\begin{array}{c}\text { T. de Asfalto } \\
(\%)\end{array}$ & $\begin{array}{c}\text { Dens. Ap } \\
(\mathbf{\%})\end{array}$ & $\mathbf{G m m}$ & $\begin{array}{c}\text { Vv } \\
(\mathbf{\%})\end{array}$ & $\begin{array}{c}\text { VAM } \\
\mathbf{( \% )}\end{array}$ & $\begin{array}{c}\text { RBV } \\
\mathbf{( \% )}\end{array}$ & $\begin{array}{c}\text { Estabilidade } \\
\mathbf{( N )}\end{array}$ & $\begin{array}{c}\text { Fluência } \\
(\mathbf{m m})\end{array}$ & $\begin{array}{c}\text { CSM } \\
\mathbf{( N / m m )}\end{array}$ \\
\hline 4,5 & 2,415 & 2,665 & 9,4 & 20,05 & 53,18 & 18343 & 3,81 & 4815 \\
5,0 & 2,472 & 2,643 & 6,5 & 18,59 & 65,26 & 17935 & 3,81 & 4707 \\
5,5 & 2,499 & 2,621 & 4,7 & 18,14 & 74,36 & 17622 & 3,81 & 4625 \\
6,0 & 2,507 & 2,600 & 3,6 & 18,32 & 80,58 & 16820 & 4,06 & 4139 \\
6,5 & 2,500 & 2,578 & 3,0 & 18,98 & 84,00 & 15949 & 4,06 & 3925 \\
\hline
\end{tabular}

Tabela 5.6 - Resultados volumétricos e de estabilidade e fluência Marshall - AMP Tipo I 60/60 com envelhecimento.

\begin{tabular}{ccccccccc}
\hline $\begin{array}{c}\text { T. de Asfalto } \\
(\%)\end{array}$ & $\begin{array}{c}\text { Dens. Ap } \\
\text { (d) }\end{array}$ & $\mathbf{G m m}$ & $\begin{array}{c}\text { Vv } \\
(\mathbf{\%})\end{array}$ & $\begin{array}{c}\text { VAM } \\
\mathbf{( \% )}\end{array}$ & $\begin{array}{c}\text { RBV } \\
(\mathbf{\%})\end{array}$ & $\begin{array}{c}\text { Estabilidade } \\
(\mathbf{N})\end{array}$ & $\begin{array}{c}\text { Fluência } \\
(\mathbf{m m})\end{array}$ & $\begin{array}{c}\text { CSM } \\
(\mathbf{N} / \mathbf{m m})\end{array}$ \\
\hline 4,5 & 2,455 & 2,663 & 7,8 & 18,74 & 58,26 & 24545 & 3,13 & 7835 \\
5,0 & 2,485 & 2,642 & 6,0 & 18,23 & 67,36 & 23829 & 3,05 & 7818 \\
5,5 & 2,499 & 2,618 & 4,5 & 18,11 & 74,99 & 24182 & 3,22 & 7516 \\
6,0 & 2,503 & 2,598 & 3,7 & 18,51 & 80,18 & 21049 & 3,81 & 5525 \\
6,5 & 2,497 & 2,576 & 3,0 & 19,09 & 84,03 & 20518 & 3,98 & 5156 \\
\hline
\end{tabular}


Tabela 5.7 - Resultados volumétricos e de estabilidade e fluência Marshall - AMP PG 76 -22 com envelhecimento.

\begin{tabular}{ccccccccc}
\hline $\begin{array}{c}\text { T. de Asfalto } \\
(\%)\end{array}$ & $\begin{array}{c}\text { Dens. Ap } \\
\text { (d) }\end{array}$ & Gmm & $\begin{array}{c}\text { Vv } \\
(\mathbf{\%})\end{array}$ & $\begin{array}{c}\text { VAM } \\
\mathbf{( \% )}\end{array}$ & $\begin{array}{c}\text { RBV } \\
(\mathbf{\%})\end{array}$ & $\begin{array}{c}\text { Estabilidade } \\
\mathbf{( N )}\end{array}$ & $\begin{array}{c}\text { Fluência } \\
(\mathbf{m m})\end{array}$ & $\begin{array}{c}\text { CSM } \\
\mathbf{( N / m m )}\end{array}$ \\
\hline 4,5 & 2,428 & 2,662 & 8,8 & 19,58 & 55,14 & 23774 & 3,30 & 7200 \\
5,0 & 2,479 & 2,641 & 6,1 & 18,39 & 66,60 & 23240 & 3,56 & 6536 \\
5,5 & 2,497 & 2,619 & 4,6 & 18,21 & 74,52 & 22457 & 3,56 & 6315 \\
6,0 & 2,500 & 2,597 & 3,7 & 18,57 & 79,82 & 18701 & 4,06 & 4602 \\
6,5 & 2,489 & 2,574 & 3,3 & 19,29 & 82,87 & 18075 & 4,06 & 4448 \\
\hline
\end{tabular}

Na Figura 5.24 é apresentado o gráfico das variações das densidades aparentes das misturas em função dos teores de ligante. Os valores encontrados para as densidades aparentes, nos teores de projeto e com envelhecimento em curto prazo para os três tipos de ligantes, foram: 2,506 para o CAP PEN 60/70, 2,502 para o AMP Tipo I 60/60 e 2,500 para o AMP PG 76 -22. Observa-se também que as densidades aparentes encontradas para o teor de projeto representam quase a densidade aparente máxima das misturas, o que não aconteceu com as misturas sem envelhecimento.

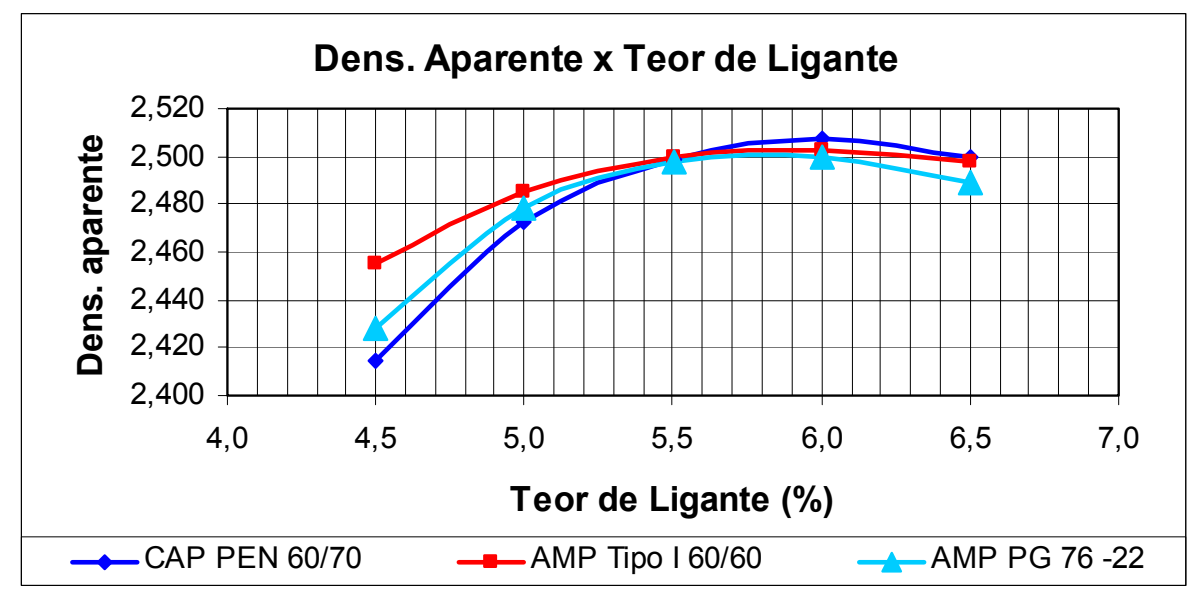

Figura 5.24 - Variação da densidade aparente em função do teor de ligante.

A Figura 5.25 apresenta a variação da densidade máxima teórica $(\mathrm{Gmm})$, obtida através do ensaio Rice das misturas, em função do teor de ligante. Pode-se observar que essa variação foi 
linear, sendo a Gmm encontrada para o teor de projeto de 5,8\% igual a 2,608 nas misturas com CAP PEN 60/70 e 2,606 para as misturas com AMP Tipo I 60/60 e PG 76 -22.

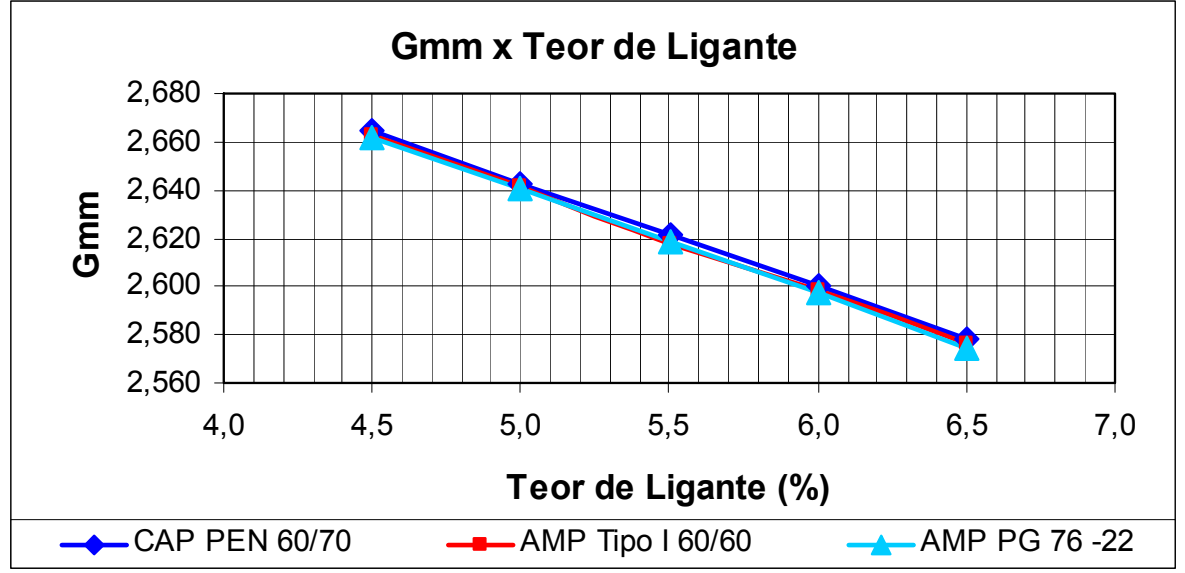

Figura 5.25 - Variação da Gmm em função do teor de ligante.

A Figura 5.26 apresenta a variação do volume de vazios em função do teor de ligante dos três asfaltos utilizados. Pode-se observar que todas as curvas apresentam um teor de projeto de $5,8 \%$ para um $\mathrm{Vv}=4 \%$.

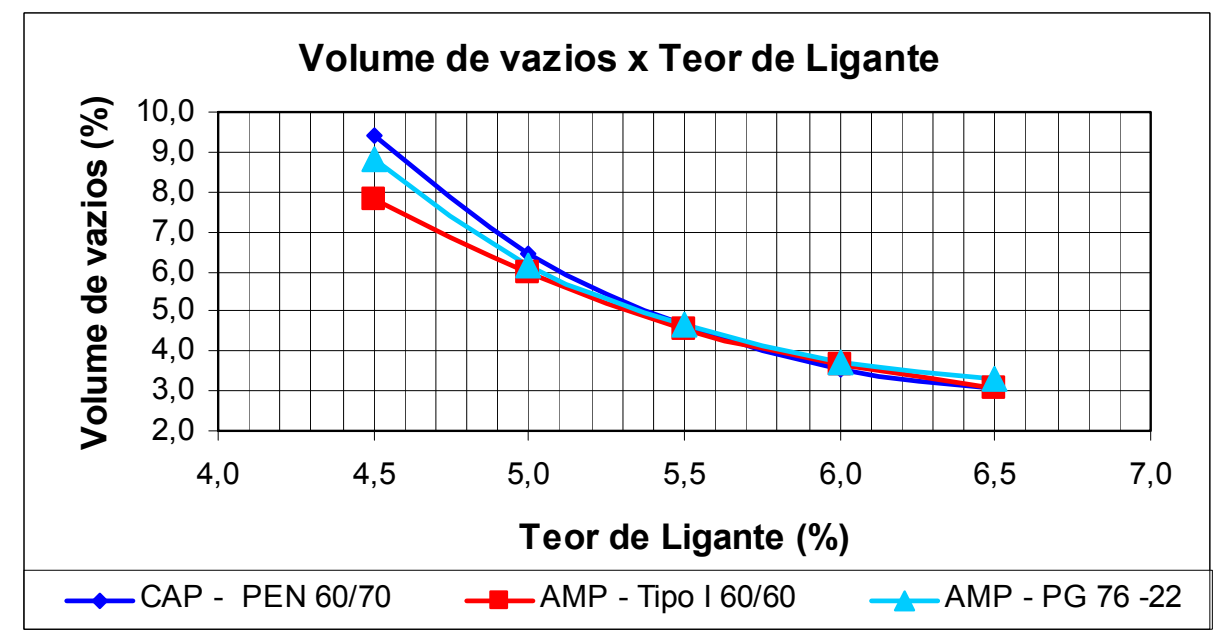

Figura 5.26 - Variação do volume de vazios em função do teor de ligante. 
A Figura 5.27 apresenta a variação do VAM em função do teor de ligante das três misturas.

Os valores encontrados para os VAM, nos teores de projeto, foram: 18,1 para o CAP PEN 60/70, 18,3 para o AMP Tipo I 60/60 e 18,4 para o AMP PG 76 -22, verificando-se que as misturas com envelhecimento em curto prazo têm maiores VAM, para todos os ligantes.

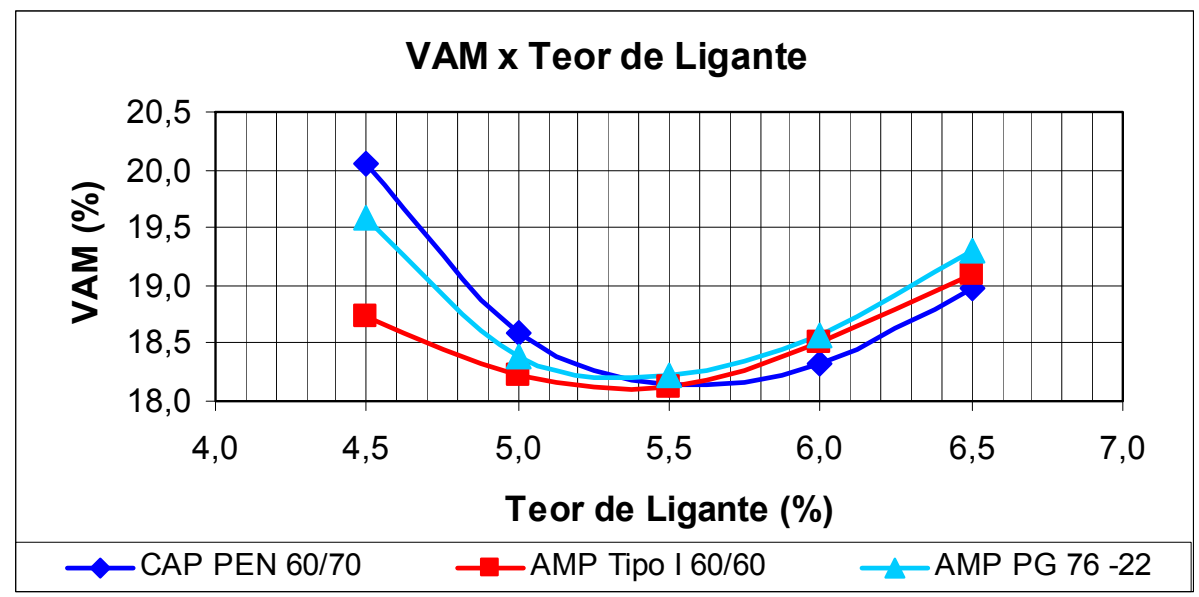

Figura 5.27 - Variação do VAM em função do teor de ligante.

A Figura 5.28 apresenta a variação da RBV das três misturas, que é similar à condição sem envelhecimento. Pode-se observar uma superposição das curvas das três misturas, tendo-se uma RBV média de 78 para o teor de projeto para os três ligantes asfálticos utilizados.

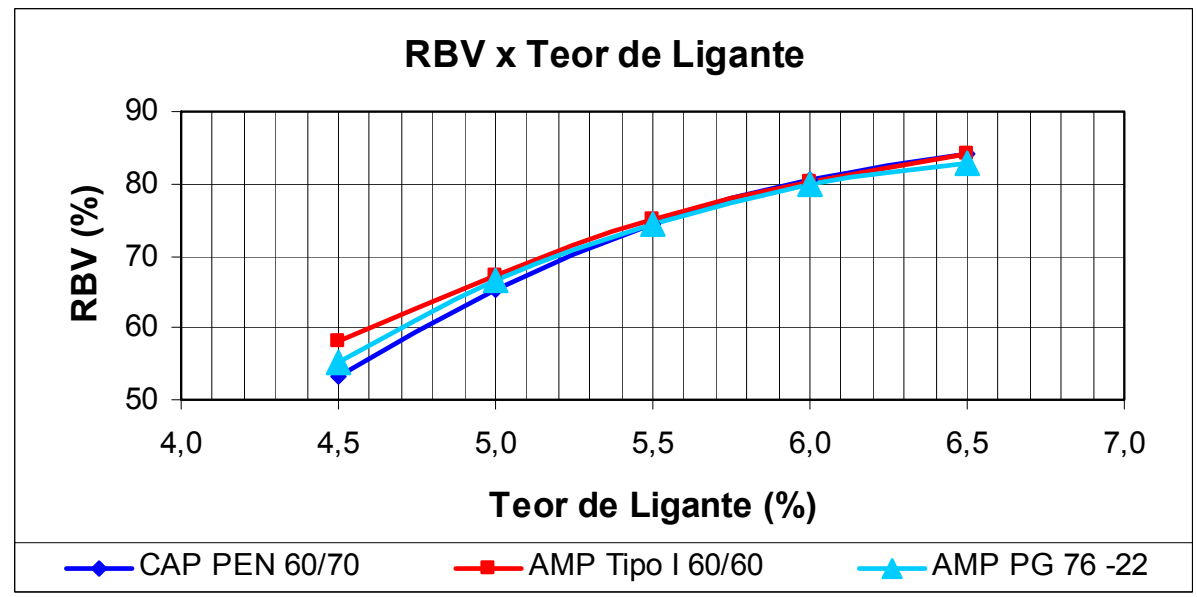

Figura 5.28 - Variação da RBV em função do teor de ligante. 
A Figura 5.29 apresenta o gráfico das estabilidades Marshall para as três misturas, verificando-se que a estabilidade máxima para o teor de projeto de 5,8\% foi de $22200 \mathrm{~N}$, obtido pelo AMP Tipo I 60/60, $20200 \mathrm{~N}$ obtido pelo AMP PG 76 -22, e 17200 N, obtido pelo CAP PEN 60/70 que foi o menor valor de estabilidade Marshall. Os resultados mostram que os asfaltos modificados por polímero apresentam os maiores valores de estabilidade Marshall.

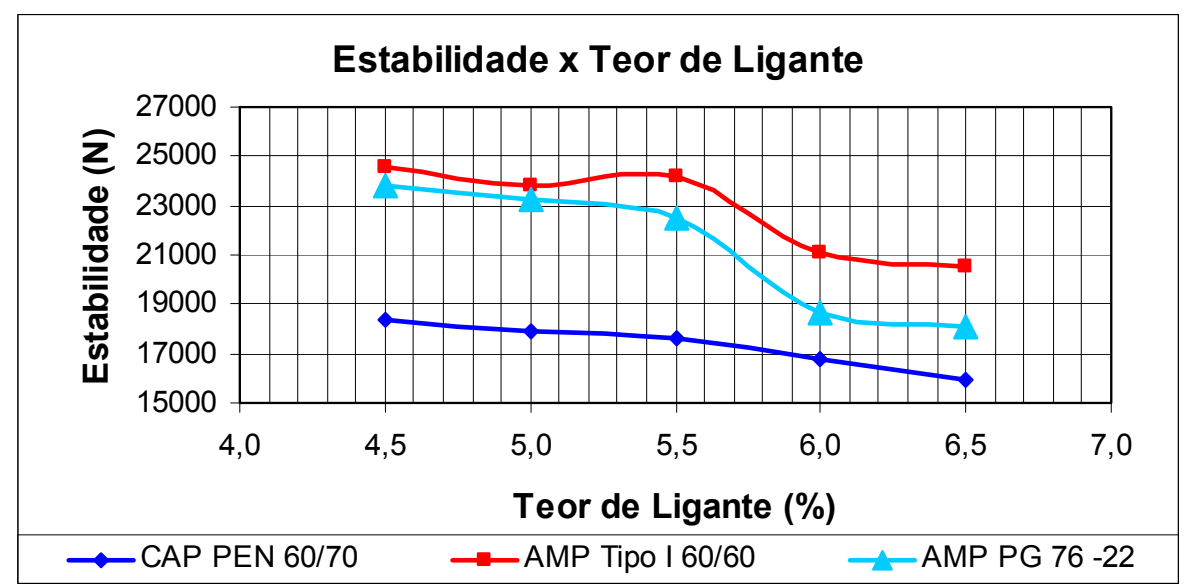

Figura 5.29 - Variação da estabilidade Marshall em função do teor de ligante.

A Figura 5.30 apresenta as curvas de Fluências das três misturas. Verifica-se que os maiores valores de fluência foram atingidos pelo CAP PEN 60/70, enquanto os AMP apresentaram os menores valores de fluência.

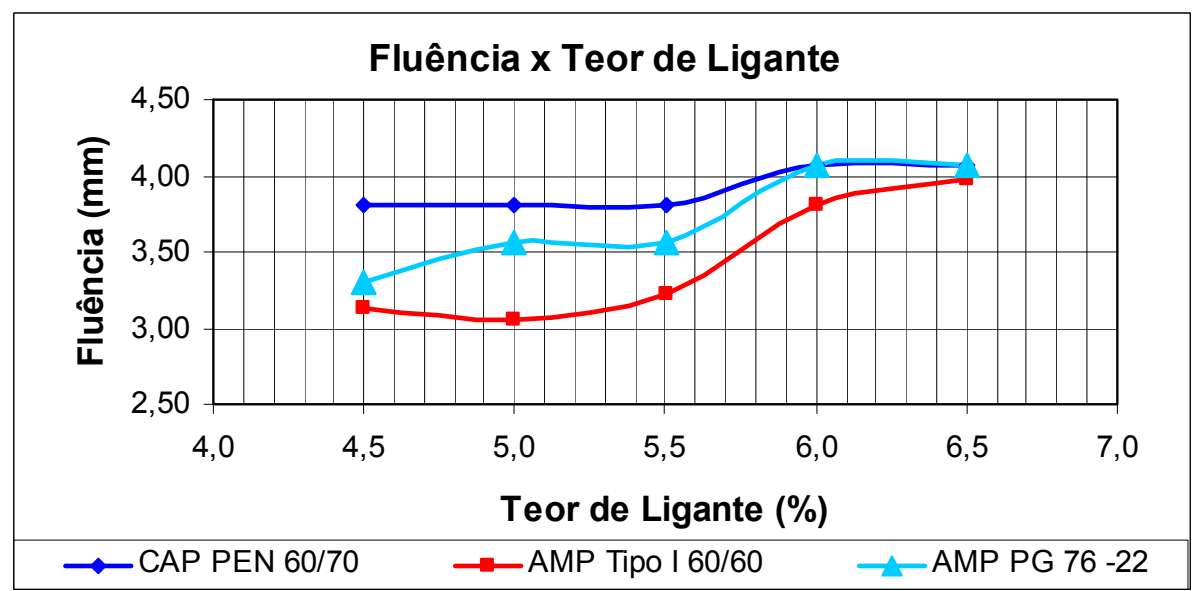

Figura 5.30 - Variação da fluência Marshall em função do teor de ligante 
A Figura 5.31 mostra as curvas da CSM onde os AMP apresentaram os maiores valores de CSM.

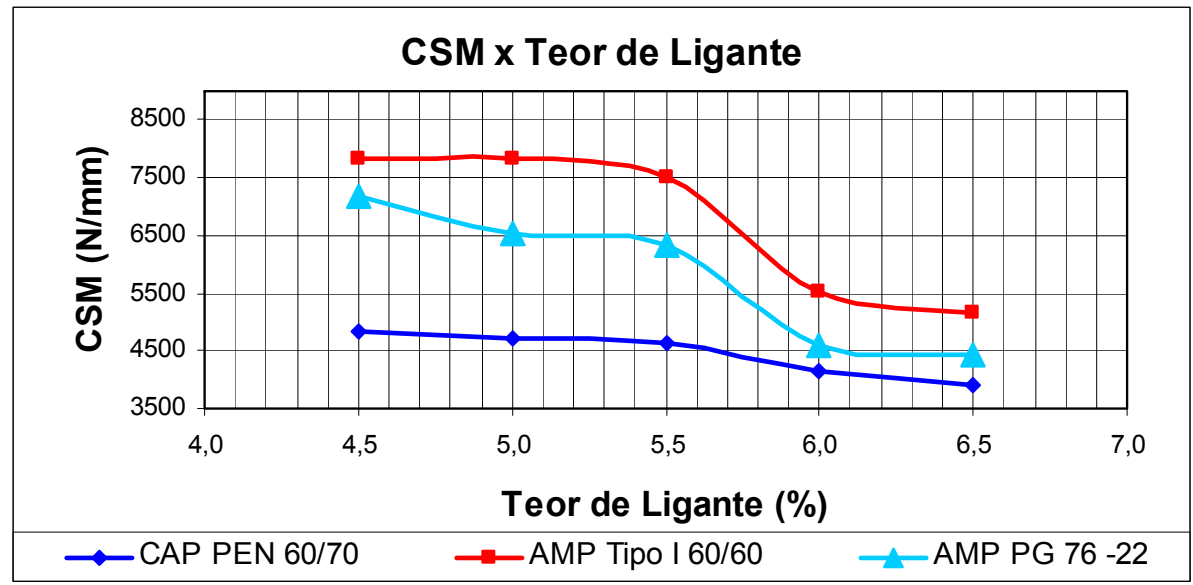

Figura 5.31 - Variação da CSM em função do teor de ligante

O teor de projeto estimado pelo método da superfície especifica foi de $5,4 \%$ e os encontrados pelo método Marshall, tomando como parâmetro de controle um volume de vazios de 4\%, foi de $5,1 \%$ para a condição sem envelhecimento e de 5,8\% para a condição com envelhecimento em curto prazo. Com esses teores de projeto para cada condição de envelhecimento foram moldados os corpos de prova para a execução dos ensaios mecânicos.

\subsubsection{Relação Fíler/Ligante}

É definida como a relação entre o fíler (dust) passante na peneira $\mathrm{N}^{\circ} 200(0,075 \mathrm{~mm})$ e o ligante efetivo. Com um percentual de $7,21 \%$ em peso de material passante na peneira $\mathrm{N}^{\circ} 200$ $(0,075 \mathrm{~mm})$, os finos certamente contribuirão para o enrijecimento da mistura, podendo por um lado, contribuir para o aumento dos módulos e, por outro, reduzir de maneira significativa a vida à fadiga das misturas ensaiadas. $\mathrm{O}$ valor da relação fíler/ligante calculado para os três tipos de ligantes asfálticos que tem um mesmo teor de ligante efetivo de 5,1\%, foi de 1,4. 
Valores altos da relação fíler/ligante indicam misturas com pouco ligante livre para atuar na inibição do trincamento. O FHWA determina valores entre 0,6 e 1,2 (AASHTO MP2-01), mas nos casos em que a granulometria passe abaixo da zona de restrição, os limites podem ser de 0,8 a 1,6. Recomenda-se que quanto mais fino o pó, mais baixa deva ser essa relação. Os efeitos negativos de valores elevados da relação fíler/ligante podem comprometer a vida de fadiga das misturas asfálticas.

\subsubsection{Ensaio de módulo de resiliência}

Para a execução do ensaio de módulo de resiliência foi levado em consideração uma taxa de deformação na faixa de 0,002 a 0,003 , com o objetivo de aplicar a menor carga possível para uma boa leitura de deslocamentos. Nenhum valor de carga aplicada superou $25 \%$ da resistência à tração, fato esse verificado a posteriori.

Os resultados dos ensaios de módulo de resiliência das misturas asfálticas, realizadas para três condições de envelhecimento e duas temperaturas, são apresentados nas Tabelas 5.8, 5.9 e 5.10

Tabela 5.8 - Resultados do ensaio de módulo de resiliência das misturas com CAP PEN 60/70.

\begin{tabular}{cccc}
\hline Condição & Temperatura $\left({ }^{\circ} \mathbf{C}\right)$ & T. asfalto (\%) & MR (MPa) \\
\hline Sem envelhecimento & 5 & 5,1 & 15615 \\
Sem envelhecimento & 25 & 5,1 & 2135 \\
Com 2 h de envelhecimento & 5 & 5,8 & 18293 \\
Com 2 h de envelhecimento & 25 & 5,8 & 4423 \\
Com 4 h de envelhecimento & 5 & 5,8 & 25219 \\
Com 4 h de envelhecimento & 25 & 5,8 & 5750 \\
\hline
\end{tabular}


Tabela 5.9 - Resultados do ensaio de módulo de resiliência das misturas com AMP Tipo I 60/60.

\begin{tabular}{cccc}
\hline Condição & Temperatura $\left({ }^{\circ} \mathbf{C}\right)$ & T. asfalto (\%) & MR (MPa) \\
\hline Sem envelhecimento & 5 & 5,1 & 18655 \\
Sem envelhecimento & 25 & 5,1 & 2335 \\
Com 2 h de envelhecimento & 5 & 5,8 & 23696 \\
Com 2 h de envelhecimento & 25 & 5,8 & 5106 \\
Com 4 h de envelhecimento & 5 & 5,8 & 22618 \\
Com 4 h de envelhecimento & 25 & 5,8 & 6189 \\
\hline
\end{tabular}

Tabela 5.10 - Resultados do ensaio de módulo de resiliência das misturas com AMP PG $76-22$.

\begin{tabular}{cccc}
\hline Condição & Temperatura $\left({ }^{\circ} \mathbf{C}\right)$ & T. asfalto (\%) & MR (MPa) \\
\hline Sem envelhecimento & 5 & 5,1 & 22617 \\
Sem envelhecimento & 25 & 5,1 & 3119 \\
Com 2 h de envelhecimento & 5 & 5,8 & 31065 \\
Com 2 h de envelhecimento & 25 & 5,8 & 6525 \\
Com 4 h de envelhecimento & 5 & 5,8 & 31595 \\
Com 4 h de envelhecimento & 25 & 5,8 & 5521 \\
\hline
\end{tabular}

Os resultados dos ensaios de módulo de resiliência de todas as misturas apresentaram uma tendência de acréscimos em função da condição de envelhecimento, tanto em temperaturas de $25^{\circ} \mathrm{C}$ como de $5^{\circ} \mathrm{C}$, fato que é atribuído ao enrijecimento sofrido pelo asfalto durante o processo de envelhecimento em curto prazo. No caso das misturas com AMP PG 76 -22, o módulo de resiliência da mistura com 4 horas de envelhecimento a $135^{\circ} \mathrm{C}$ resultou ser menor que o da mistura com 2 horas de envelhecimento a temperatura de compactação, fenômeno atribuído ao fato do ligante apresentar as maiores temperaturas de compactação $\left(165^{\circ} \mathrm{C}\right)$ na qual a mistura permanece por um tempo de duas horas.

Os módulos de resiliência sofreram acréscimos com a diminuição da temperatura. Para as misturas sem envelhecimento o acréscimo foi de 631\% para o CAP PEN 60/70, 698\% para o 
AMP Tipo I 60/60 e 625\% para o AMP PG 76 -22; no caso das misturas com 2 horas de envelhecimento os acréscimos apresentados foram de 313\% para o CAP PEN 60/70, 364\% para o AMP Tipo I 60/60 e 376\% para o AMP PG 76 -22; para as misturas com 4 horas de envelhecimento, os acréscimos apresentados foram bem variáveis, 338\% para o CAP PEN 60/70, 275\% para o AMP Tipo I 60/60 e 472\% para o AMP PG $76-22$. Pode-se observar que as misturas sem envelhecimento apresentaram as maiores taxas de enrijecimento pelo efeito da variação da temperatura. A variação do módulo de resiliência em função da temperatura de ensaio e condição de envelhecimento pode ser melhor observado nas Figuras $5.32,5.33$ e 5.34

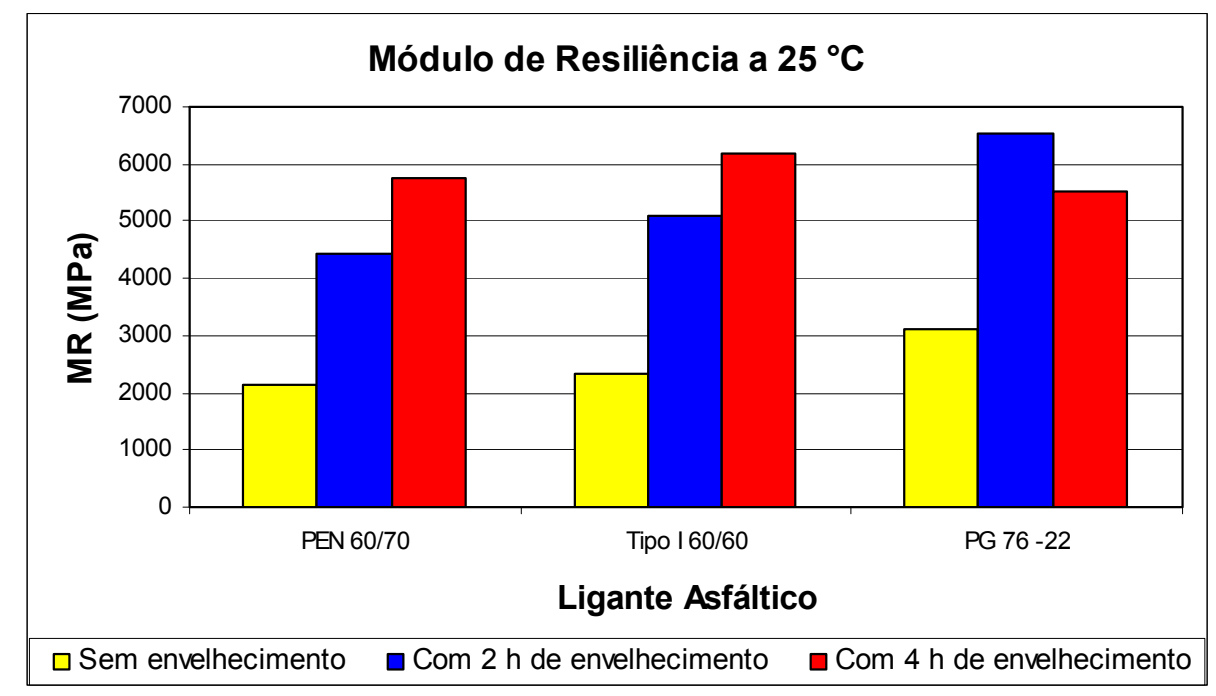

Figura 5.32 - Variação do MR a $25^{\circ} \mathrm{C}$ em função da condição de envelhecimento. 


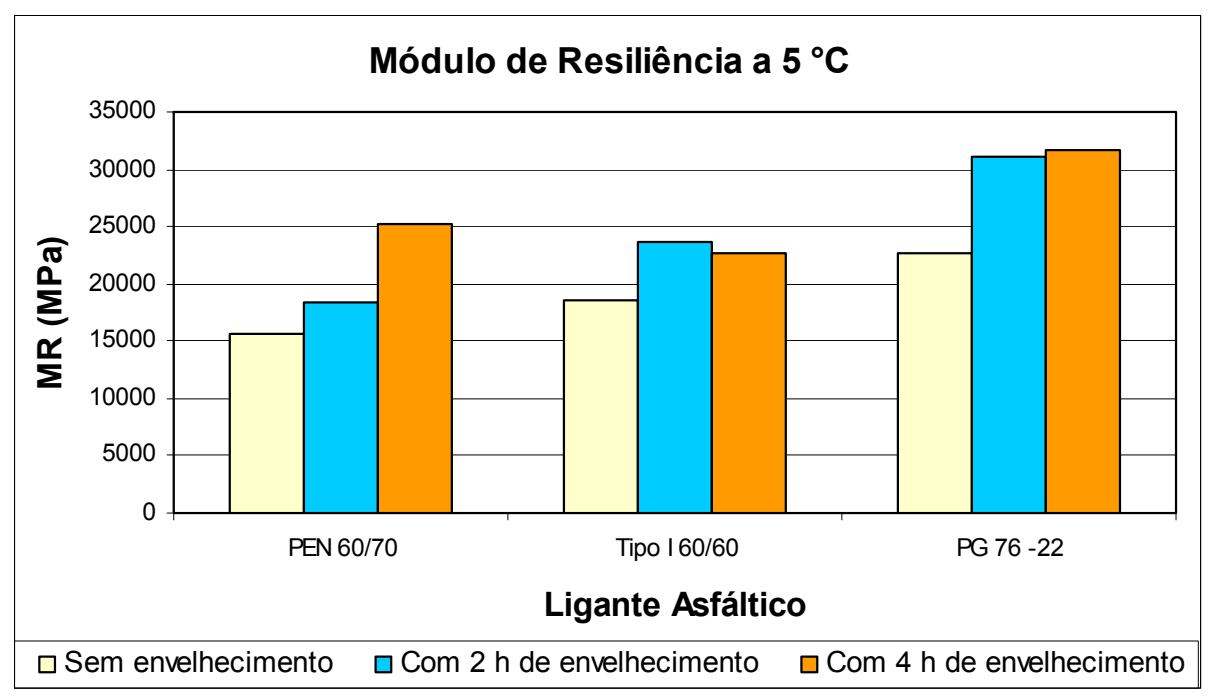

Figura 5.33 - Variação do $\mathrm{MR}$ a $5^{\circ} \mathrm{C}$ em função da condição de envelhecimento.

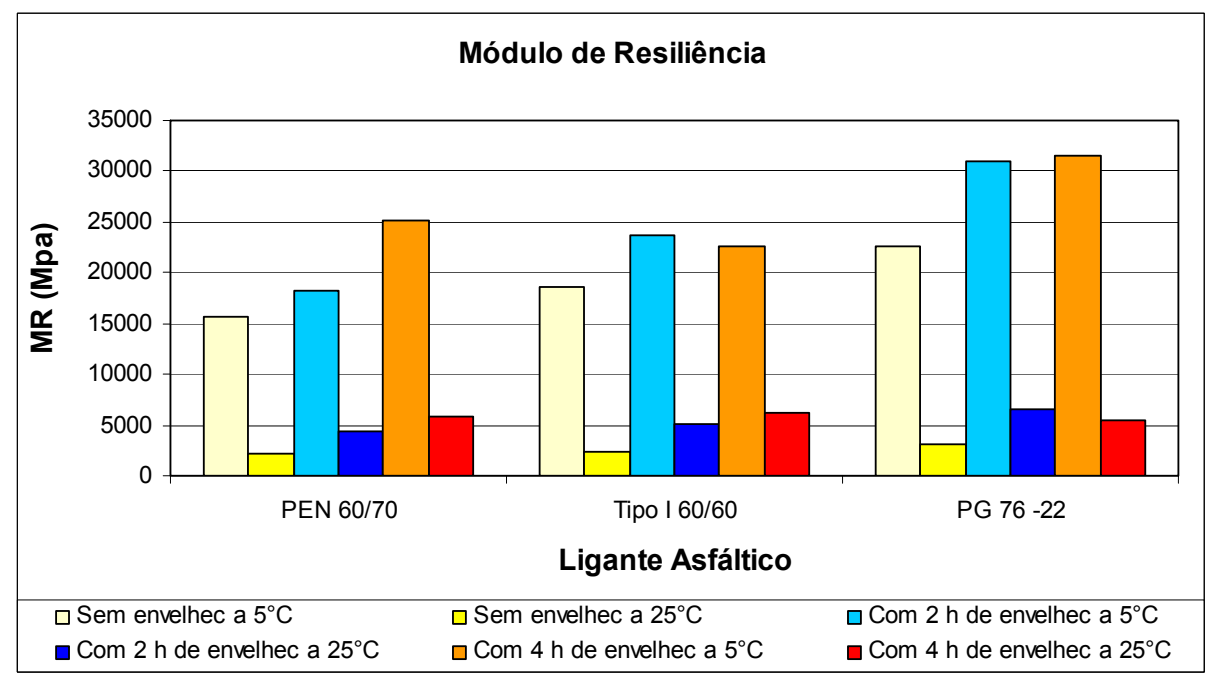

Figura 5.34 - Variação do MR das misturas em função da temperatura e condição de envelhecimento em curto prazo.

\subsubsection{Ensaio de resistência à tração por compressão diametral}

Os resultados dos ensaios de resistência à tração das misturas asfálticas, realizados para três condições de envelhecimento e duas temperaturas, são apresentados nas Tabelas 5.11, 5.12 e 5.13 . 
Tabela 5.11 - Resultados do ensaio de resistência à tração das misturas com CAP PEN 60/70.

\begin{tabular}{cccc}
\hline Condição & Temperatura $\left({ }^{\circ} \mathbf{C}\right)$ & T. asfalto (\%) & RT (Mpa) \\
\hline Sem envelhecimento & 5 & 5,1 & 3,24 \\
Sem envelhecimento & 25 & 5,1 & 0,97 \\
Com 2 h de envelhecimento & 5 & 5,8 & 3,26 \\
Com 2 h de envelhecimento & 25 & 5,8 & 1,29 \\
Com 4 h de envelhecimento & 5 & 5,8 & 3,41 \\
Com 4 h de envelhecimento & 25 & 5,8 & 1,58 \\
\hline
\end{tabular}

Tabela 5.12 - Resultados do ensaio de resistência à tração das misturas com AMP Tipo I 60/60.

\begin{tabular}{cccc}
\hline Condição & Temperatura $\left({ }^{\circ} \mathbf{C}\right)$ & T. asfalto (\%) & RT (Mpa) \\
\hline Sem envelhecimento & 5 & 5,1 & 3,83 \\
Sem envelhecimento & 25 & 5,1 & 1,21 \\
Com 2 h de envelhecimento & 5 & 5,8 & 4,20 \\
Com 2 h de envelhecimento & 25 & 5,8 & 1,65 \\
Com 4 h de envelhecimento & 5 & 5,8 & 4,35 \\
Com 4 h de envelhecimento & 25 & 5,8 & 1,78 \\
\hline
\end{tabular}

Tabela 5.13 - Resultados do ensaio de resistência à tração das misturas com AMP PG 76 -22.

\begin{tabular}{cccc}
\hline Condição & Temperatura $\left({ }^{\circ} \mathbf{C}\right)$ & T. asfalto (\%) & RT (Mpa) \\
\hline Sem envelhecimento & 5 & 5,1 & 4,58 \\
Sem envelhecimento & 25 & 5,1 & 1,36 \\
Com 2 h de envelhecimento & 5 & 5,8 & 5,44 \\
Com 2 h de envelhecimento & 25 & 5,8 & 1,90 \\
Com 4 h de envelhecimento & 5 & 5,8 & 5,22 \\
Com 4 h de envelhecimento & 25 & 5,8 & 1,92 \\
\hline
\end{tabular}

Os resultados da RT de todas as misturas apresentaram uma tendência de acréscimos em função da condição de envelhecimento, nas duas temperaturas, sendo as misturas com CAP PEN 60/70 as que apresentaram as maiores taxas de acréscimo em comparação com os AMP.

A resistência à tração seguiu aproximadamente a mesma tendência que o módulo de resiliência, sofrendo acréscimos com a diminuição da temperatura. Os acréscimos foram, 
também, variáveis em função da condição de envelhecimento: para as misturas sem envelhecimento, o acréscimo foi de 234\% para o CAP PEN 60/70, 216\% para o AMP Tipo I 60/60 e 238\% para o AMP PG 76 -22; no caso das misturas com 2 horas de envelhecimento na temperatura de compactação, os acréscimos apresentados foram de $153 \%$ para o CAP PEN 60/70, 155\% para o AMP Tipo I 60/60 e 186\% para o AMP PG 76 -22; para as misturas com 4 horas de envelhecimento a $135^{\circ} \mathrm{C}$ os acréscimos apresentados foram bem variáveis, de 116\% para o CAP PEN 60/70, 144\% para o AMP Tipo I 60/60 e 172\% para o AMP PG 76 22. Essa variação da RT para todas as condições de envelhecimento e temperatura, similar ao observado no módulo de resiliência, nesta pesquisa mostrou uma relação entre essas duas propriedades mecânicas.

As Figuras 5.35, 5.36 e 5.37 apresentam as variações da RT em relação à temperatura de ensaio e condição de envelhecimento.

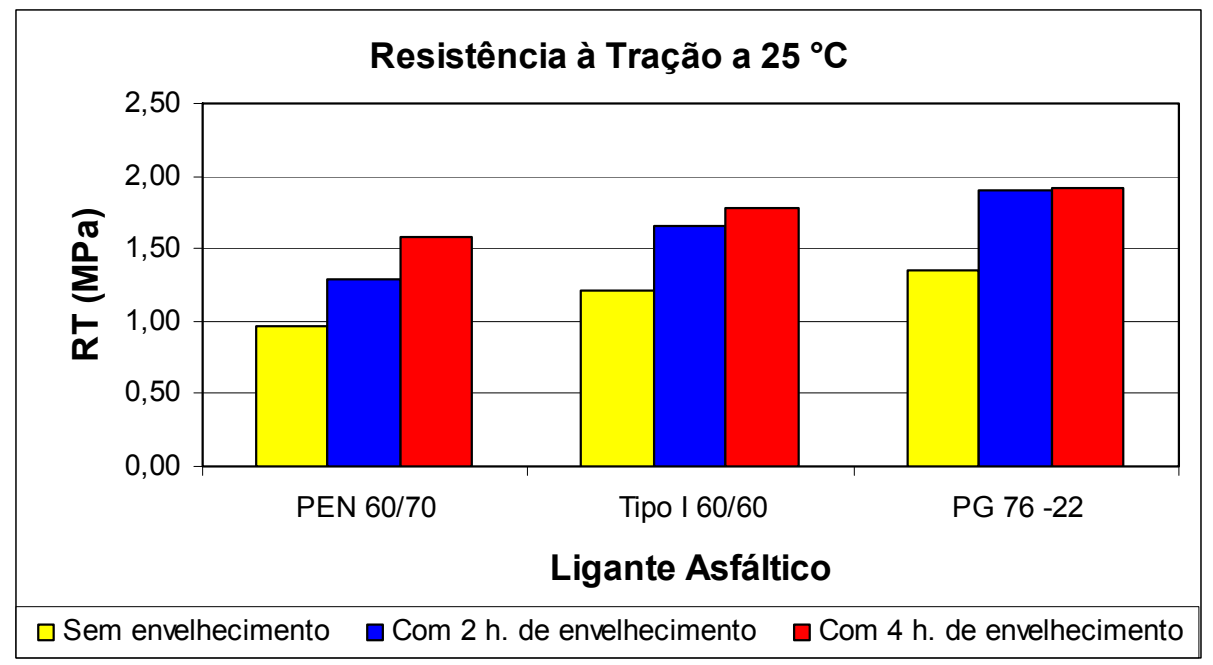

Figura 5.35 - Variação da RT a $25^{\circ} \mathrm{C}$ em função da condição de envelhecimento. 


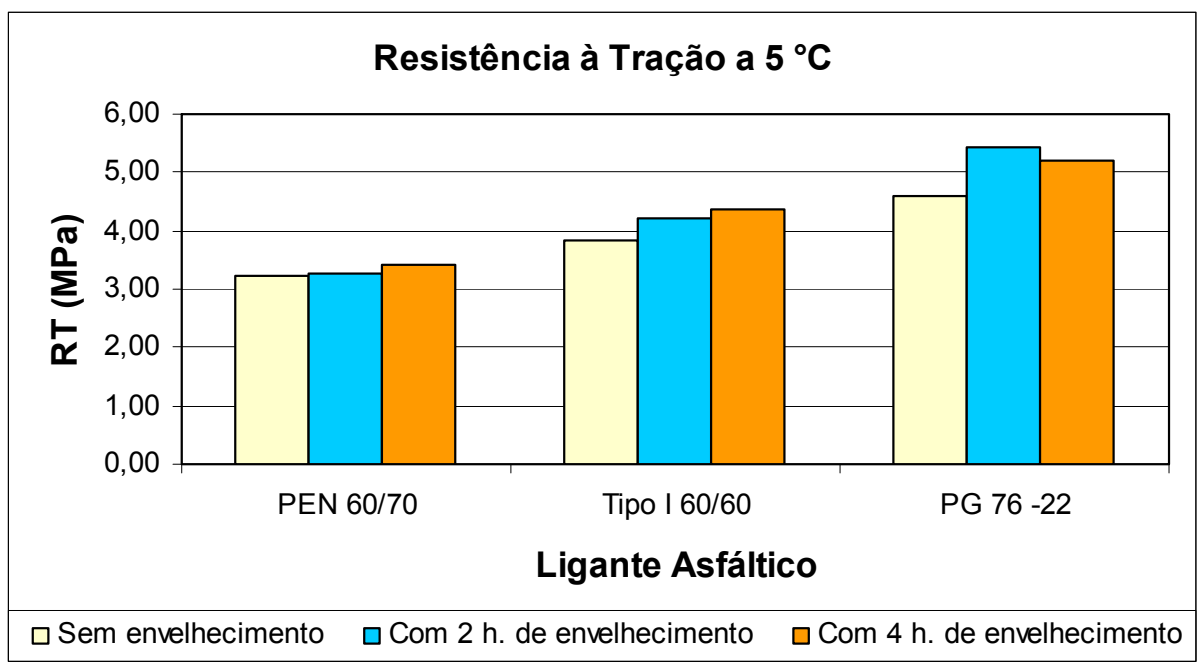

Figura 5.36 - Variação da RT a $5^{\circ} \mathrm{C}$ em função da condição de envelhecimento.

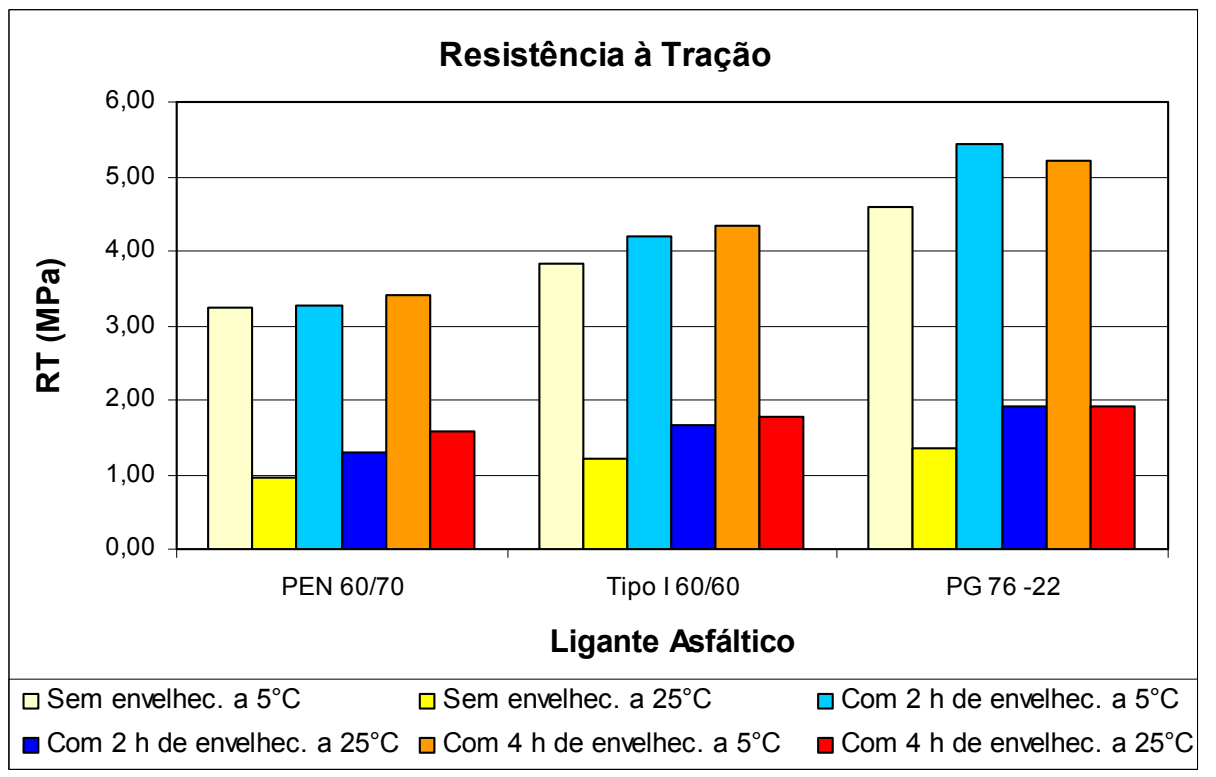

Figura 5.37 - Variação da RT em função da temperatura de ensaio e condição de envelhecimento.

Os resultados da resistência à tração das misturas asfálticas com AMP PG 76 -22 foram superiores, em todas as condições, aos resultados da RT das misturas com AMP Tipo I 60/60, que por sua vez, foram superiores aos resultados obtidos com CAP PEN 60/70, constatando-se, assim, as maiores resistências à tração dos asfaltos modificados por polímero SBS encontradas em pesquisas anteriores. 


\subsubsection{Relação MR/RT}

A relação $\mathrm{MR} / \mathrm{RT}$ indica uma tendência da compatibilidade entre a rigidez e a resistência da mistura asfáltica. Misturas asfálticas muito rígidas, com MR elevado, necessitam de altos valores de RT devido à concentração de esforços em seu interior. A relação MR/RT é apresentada como um parâmetro de comparação entre as misturas asfálticas no que diz respeito ao comportamento à fadiga. Pinheiro et al. (2003), sugerem que misturas asfálticas com relações MR/RT da ordem de 3000 apresentam um bom comportamento estrutural, em razão da flexibilidade aliada à resistência à tração e portanto, maior vida de fadiga. Porém, este parâmetro não é válido para todo tipo de materiais. As Tabelas 5.14, 5.15 e 5.16, apresentam, respectivamente, a relação $\mathrm{MR} / \mathrm{RT}$ para as misturas com asfalto convencional PEN 60/70, AMP Tipo I 60/60 e AMP PG 76 -22.

Tabela 5.14 - Resultados da relação MR/RT das misturas com CAP PEN 60/70.

\begin{tabular}{cccc}
\hline Condição & Temperatura $\left({ }^{\circ} \mathbf{C}\right)$ & T. asfalto (\%) & MR/RT \\
\hline Sem envelhecimento & 5 & 5,1 & 4813 \\
Sem envelhecimento & 25 & 5,1 & 2205 \\
Com 2 h de envelhecimento & 5 & 5,8 & 5618 \\
Com 2 h de envelhecimento & 25 & 5,8 & 3419 \\
Com 4 h de envelhecimento & 5 & 5,8 & 7391 \\
Com 4 h de envelhecimento & 25 & 5,8 & 3631 \\
\hline
\end{tabular}

Tabela 5.15 - Resultados da relação MR/RT das misturas com AMP Tipo I 60/60.

\begin{tabular}{cccc}
\hline Condição & Temperatura $\left({ }^{\circ} \mathbf{C}\right)$ & T. asfalto (\%) & MR/RT \\
\hline Sem envelhecimento & 5 & 5,1 & 4875 \\
Sem envelhecimento & 25 & 5,1 & 1925 \\
Com 2 h de envelhecimento & 5 & 5,8 & 5638 \\
Com 2 h de envelhecimento & 25 & 5,8 & 3092 \\
Com 4 h de envelhecimento & 5 & 5,8 & 5201 \\
Com 4 h de envelhecimento & 25 & 5,8 & 3479 \\
\hline
\end{tabular}


Tabela 5.16 - Resultados da relação MR/RT das misturas com AMP PG 76 -22.

\begin{tabular}{cccc}
\hline Condição & Temperatura $\left({ }^{\circ} \mathbf{C}\right)$ & T. asfalto (\%) & MR/RT \\
\hline Sem envelhecimento & 5 & 5,1 & 4934 \\
Sem envelhecimento & 25 & 5,1 & 2302 \\
Com 2 h de envelhecimento & 5 & 5,8 & 5708 \\
Com 2 h de envelhecimento & 25 & 5,8 & 3427 \\
Com 4 h de envelhecimento & 5 & 5,8 & 6051 \\
Com 4 h de envelhecimento & 25 & 5,8 & 2873 \\
\hline
\end{tabular}

As relações MR/RT apresentaram a mesma tendência do módulo de resiliência. Os acréscimos da relação $\mathrm{MR} / \mathrm{RT}$ com a diminuição da temperatura de $25^{\circ} \mathrm{C}$ para $5^{\circ} \mathrm{C}$ foram variáveis na taxa de 49,5\% a $153 \%$, apresentando-se os maiores acréscimos nas misturas sem envelhecimento e com 4 horas de envelhecimento a $135^{\circ} \mathrm{C}$, sendo que os menores acréscimos se apresentaram nas misturas com 2 horas de envelhecimento, variáveis entre $64 \%$ a $82 \%$.

A condição de envelhecimento mostrou que as misturas sem envelhecimento apresentaram as menores relações MR/RT, em torno de 1925 a 2302, na qual o AMP Tipo I 60/60 apresentou o menor valor. Para a condição de 2 horas de envelhecimento essa relação foi na faixa de 3092 a 3427, sendo que o AMP Tipo I 60/60 apresentou uma relação MR/RT de 3092, próximo de 3000, que segundo Leite et al. (2000), caracterizam misturas com boa flexibilidade e resistência à tração. Para a condição de 4 horas de envelhecimento os valores foram variáveis na faixa de 2873 a 3631 , sendo que os valores mais próximos de 3000 foram atingidos pelos AMP. Porém, o recomendável é realizar uma análise mecanística.

As relações MR/RT das misturas estudadas podem ser melhor observados nas Figuras 5.38, 5.39 e 5.40 onde são representadas as relações MR/RT em função da temperatura do ensaio e condição de envelhecimento. 


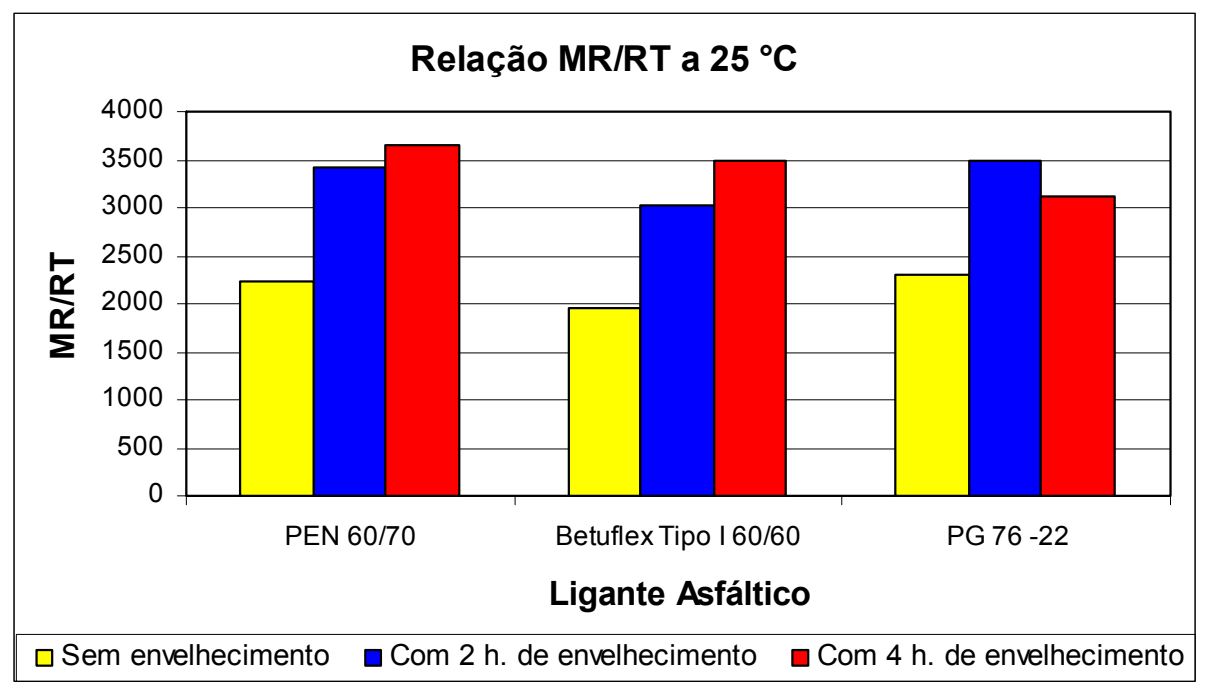

Figura 5.38 - Variação da relação $\mathrm{MR} / \mathrm{RT}$ a $25^{\circ} \mathrm{C}$ em função da condição de envelhecimento.

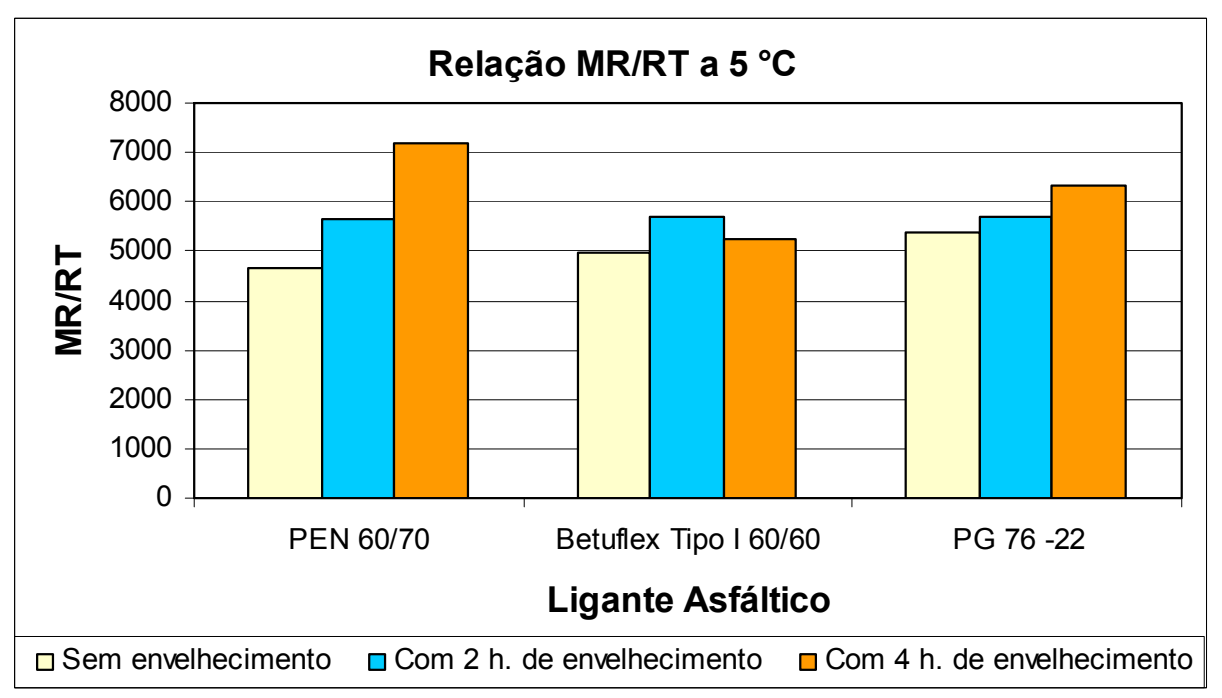

Figura 5.39 - Variação da relação $\mathrm{MR} / \mathrm{RT}$ a $5^{\circ} \mathrm{C}$ em função da condição de envelhecimento. 


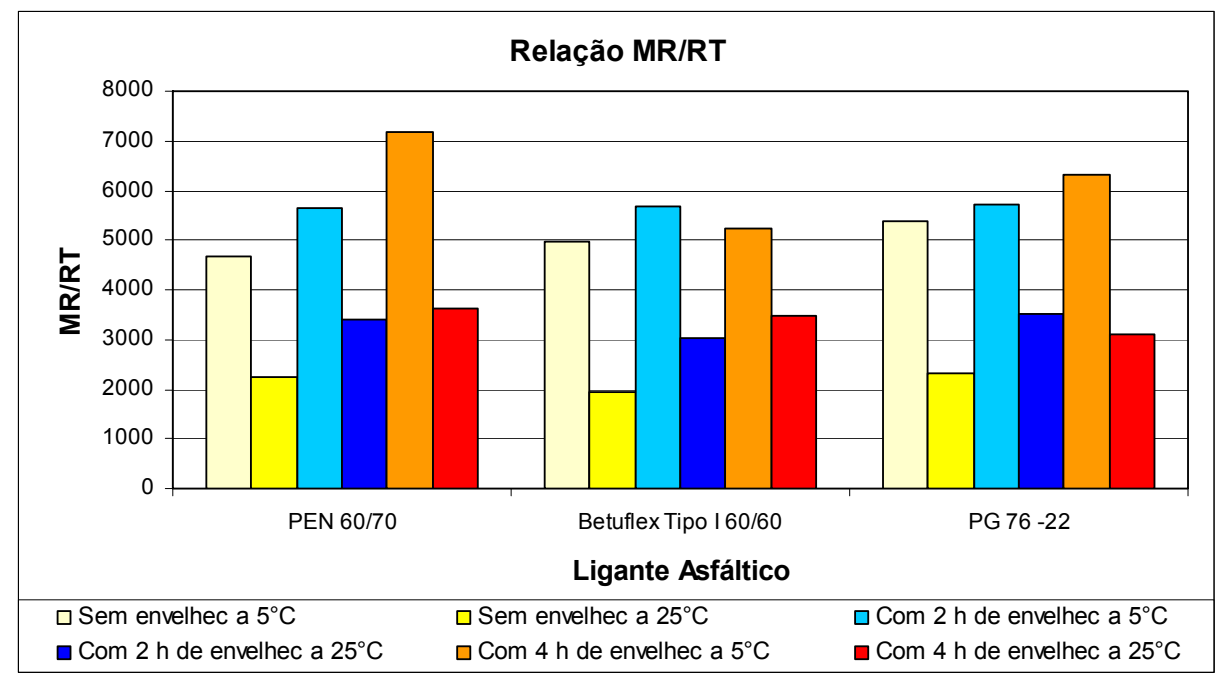

Figura 5.40 - Variação da relação MR/RT em função da temperatura de ensaio e condição de envelhecimento.

\subsubsection{Ensaio de resistência à tração retida por umidade induzida}

A avaliação do dano causado pela umidade é de grande importância, por afetar diretamente o desempenho do pavimento. Os resultados dos ensaios para identificação do dano causado pela umidade nas misturas estudadas são apresentados nas Tabelas 5.17, 5.18 e 5.19.

Tabela 5.17 - Resultados da RTR das misturas com CAP PEN 60/70.

\begin{tabular}{cccc}
\hline Condição & $\begin{array}{c}\text { RT Sem } \\
\text { condicionamento }\end{array}$ & $\begin{array}{c}\text { RT Com } \\
\text { condicionamento }\end{array}$ & RTR \\
\hline Sem envelhecimento & 0,97 & 0,95 & $98 \%$ \\
Com 2 h. de envelhecimento & 1,29 & 1,24 & $96 \%$ \\
Com 4 h. de envelhecimento & 1,58 & 1,42 & $90 \%$ \\
\hline
\end{tabular}

Tabela 5.18 - Resultados da RTR das misturas com AMP Tipo I 60/60.

\begin{tabular}{cccc}
\hline Condição & $\begin{array}{c}\text { RT Sem } \\
\text { condicionamento }\end{array}$ & $\begin{array}{c}\text { RT Com } \\
\text { condicionamento }\end{array}$ & RTR \\
\hline Sem envelhecimento & 1,21 & 1,19 & $98 \%$ \\
Com 2 h. de envelhecimento & 1,65 & 1,61 & $97 \%$ \\
Com 4 h. de envelhecimento & 1,78 & 1,64 & $92 \%$ \\
\hline
\end{tabular}


Tabela 5.19 - Resultados da RTR das misturas com AMP PG 76 -22.

\begin{tabular}{cccc}
\hline Condição & $\begin{array}{c}\text { RT Sem } \\
\text { condicionamento }\end{array}$ & $\begin{array}{c}\text { RT Com } \\
\text { condicionamento }\end{array}$ & RTR \\
\hline Sem envelhecimento & 1,36 & 1,35 & $100 \%$ \\
Com 2 h. de envelhecimento & 1,90 & 1,86 & $98 \%$ \\
Com 4 h. de envelhecimento & 1,92 & 1,84 & $96 \%$ \\
\hline
\end{tabular}

Os resultados mostraram que os ligantes asfálticos utilizados na pesquisa apresentaram excelentes propriedades de resistência à umidade induzida. Mesmo com todos os corpos de prova saturados na faixa de 70 a $80 \%$, observa-se que as RTR são superiores a $90 \%$, superando amplamente o critério para aceitação especificado em $80 \%$. As misturas que sofreram a maior taxa de variação foram as misturas com 4 horas de envelhecimento a $135^{\circ} \mathrm{C}$.

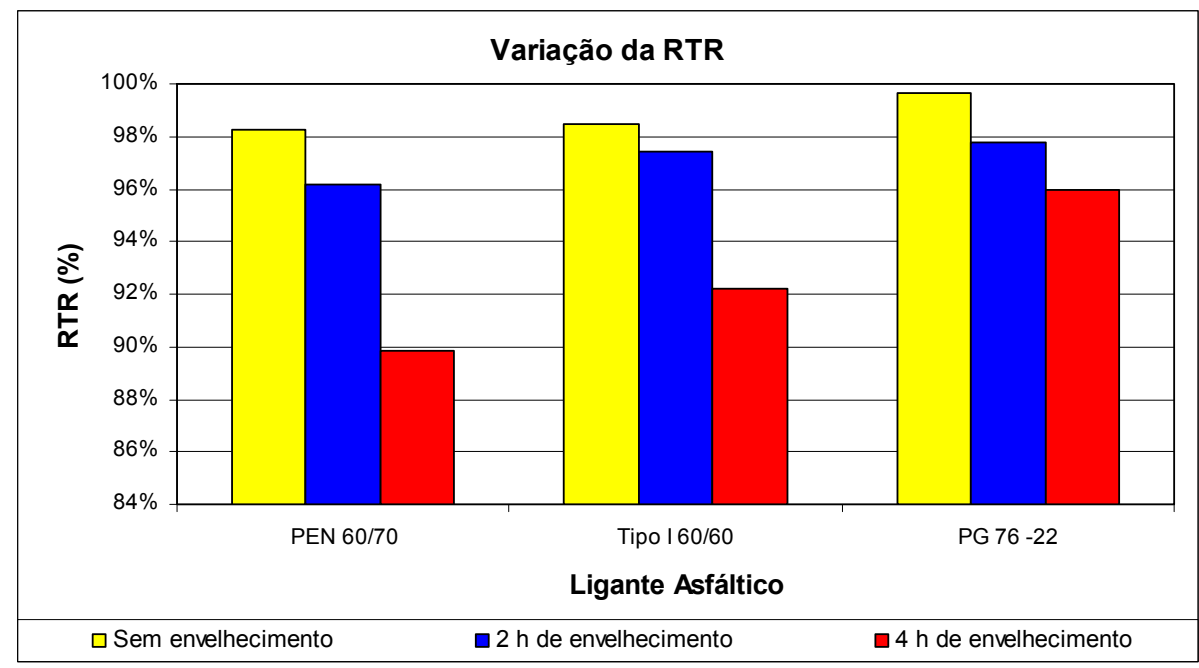

Figura 5.41 - Variação da RTR em função da condição de envelhecimento.

Durante a execução do ensaio também foram feitos ensaios de módulos de resiliência, com a finalidade de avaliar variações do módulo de resiliência dos corpos de prova decorrentes do condicionamento e a retenção do módulo de resiliência (MRR), cujos resultados são apresentados nas Tabelas 5.20, 5.21 e 5.22. 
Tabela 5.20 - Resultados da MRR das misturas com CAP PEN 60/70.

\begin{tabular}{cccc}
\hline Condição & $\begin{array}{c}\text { MR Sem } \\
\text { condicionamento }\end{array}$ & $\begin{array}{c}\text { MR Com } \\
\text { condicionamento }\end{array}$ & MRR \\
\hline Sem envelhecimento & 2276 & 2302 & $101 \%$ \\
Com 2 h. de envelhecimento & 4282 & 4452 & $104 \%$ \\
Com 4 h. de envelhecimento & 5462 & 5566 & $102 \%$ \\
\hline
\end{tabular}

Tabela 5.21 - Resultados da MRR das misturas com AMP Tipo I 60/60.

\begin{tabular}{cccc}
\hline Condição & $\begin{array}{c}\text { MR Sem } \\
\text { condicionamento }\end{array}$ & $\begin{array}{c}\text { MR Com } \\
\text { condicionamento }\end{array}$ & MRR \\
\hline Sem envelhecimento & 2366 & 2554 & $108 \%$ \\
Com 2 h. de envelhecimento & 4636 & 5057 & $109 \%$ \\
Com 4 h. de envelhecimento & 6064 & 6425 & $106 \%$ \\
\hline
\end{tabular}

Tabela 5.22 - Resultados da MRR das misturas com AMP PG 76 -22.

\begin{tabular}{cccc}
\hline Condição & $\begin{array}{c}\text { MR Sem } \\
\text { condicionamento }\end{array}$ & $\begin{array}{c}\text { MR Com } \\
\text { condicionamento }\end{array}$ & MRR \\
\hline Sem envelhecimento & 3291 & 3541 & $108 \%$ \\
Com 2 h. de envelhecimento & 6439 & 7027 & $109 \%$ \\
Com 4 h. de envelhecimento & 5366 & 5925 & $110 \%$ \\
\hline
\end{tabular}

Os resultados dos ensaios de módulo de resiliência apresentaram uma pequena taxa de acréscimo (menores que 10\%) em todos os ligantes asfálticos. Porém, pela baixa taxa de variação podem ser atribuídos à variabilidade do ensaio. Furlan et al. (2004) e Gouveia et al. (2004), propõem que semelhante ao ensaio de resistência à tração, as misturas que apresentam relação de módulo de resiliência (MRR) maior que 70\% são consideradas aceitáveis, embora ainda não exista critério estabelecido. Avaliando segundo este critério, todas as misturas asfálticas superariam amplamente o critério de aceitação. A Figura 5.42 apresenta a variação da MRR para todas as condições de envelhecimento. 


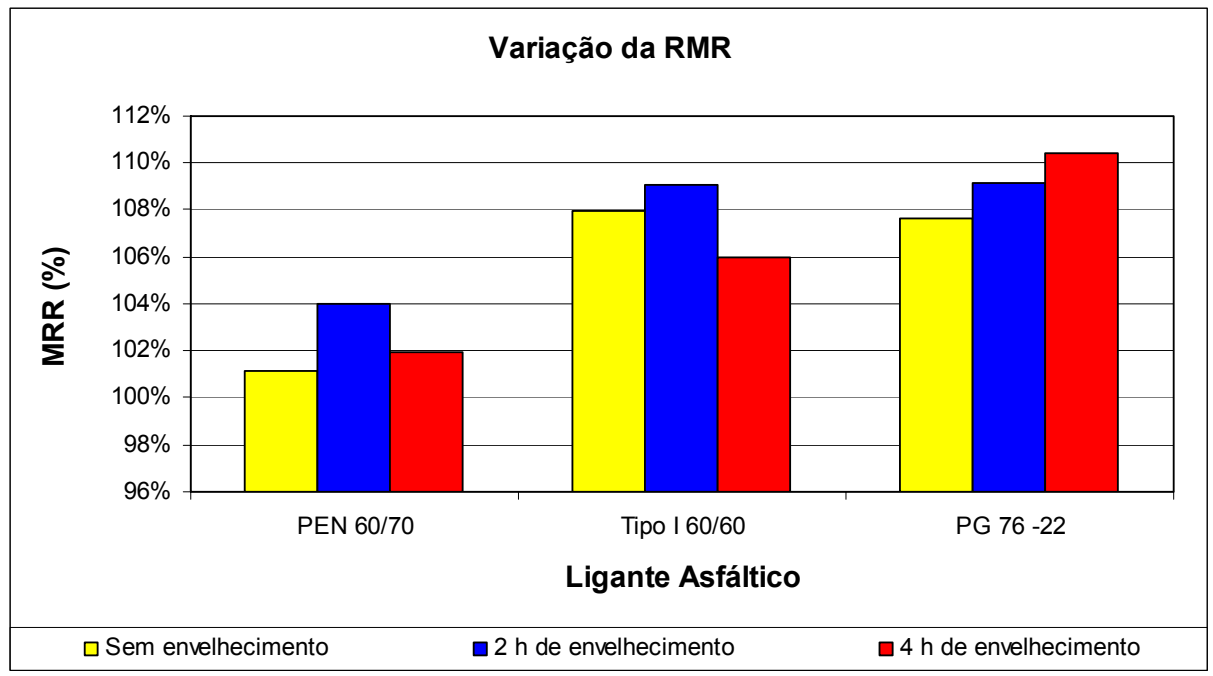

Figura 5.42 - Variação da RMR em função da condição de envelhecimento.

\subsubsection{Ensaio de fluência por compressão uniaxial estática (“creep estático")}

O ensaio de fluência por compressão uniaxial estática tem sido utilizado para estimar a susceptibilidade das misturas asfálticas à deformação permanente. Os parâmetros avaliados foram: deformação total (3600 s), inclinação da curva de fluência no estágio secundário (entre 1000 e 3600 s), recuperação, módulos de fluência para 3600 s de ensaio e para 4500 s (após a recuperação).

Os resultados do ensaio para avaliação da susceptibilidade das misturas asfálticas estudadas à deformação permanente são apresentados nas Tabelas 5.23, 5.24 e 5.25. 
Tabela 5.23 - Resultados do ensaio de fluência por compressão uniaxial estática das misturas com CAP PEN 60/70.

\begin{tabular}{|c|c|c|c|c|c|c|c|}
\hline Condição & $\begin{array}{c}\text { Deformação } \\
\text { Total } \\
(\%)\end{array}$ & $\begin{array}{c}\text { Deformação } \\
\text { não Recup. } \\
(\%)\end{array}$ & $\begin{array}{c}\text { Deformação } \\
\text { Recup. } \\
(\%)\end{array}$ & $\begin{array}{c}\text { Recup. } \\
(\%)\end{array}$ & $\begin{array}{c}\text { Mf } \\
\mathrm{t}=3600 \mathrm{~s} \\
(\mathrm{MPa})\end{array}$ & $\begin{array}{c}\text { Mf } \\
\mathrm{t}=4500 \mathrm{~s} \\
(\mathrm{MPa})\end{array}$ & Inclinação \\
\hline Sem envelhec & 0,227 & 0,101 & 0,126 & 57,8 & 190 & 606 & 0,076 \\
\hline $2 \mathrm{~h}$ de envelhec & 0,238 & 0,119 & 0,119 & 51,5 & 179 & 397 & 0,121 \\
\hline $4 \mathrm{~h}$ de envelhec & 0,270 & 0,148 & 0,122 & 57,0 & 158 & 360 & 0,121 \\
\hline
\end{tabular}

Tabela 5.24 - Resultados do ensaio de fluência por compressão uniaxial estática das misturas com AMP Tipo I 60/60.

\begin{tabular}{|c|c|c|c|c|c|c|c|}
\hline Condição & $\begin{array}{c}\text { Deformação } \\
\text { Total } \\
(\%)\end{array}$ & $\begin{array}{c}\text { Deformação } \\
\text { não Recup. } \\
\text { (\%) }\end{array}$ & $\begin{array}{c}\text { Deformação } \\
\text { Recup. } \\
(\%)\end{array}$ & $\begin{array}{c}\text { Recup. } \\
(\%)\end{array}$ & $\begin{array}{c}\text { Mf } \\
\mathrm{t}=3600 \mathrm{~s} \\
\text { (MPa) }\end{array}$ & $\begin{array}{c}\text { Mf } \\
\mathrm{t}=4500 \mathrm{~s} \\
(\mathrm{MPa})\end{array}$ & Inclinação \\
\hline Sem envelhec & 0,241 & 0,075 & 0,166 & 69,4 & 175 & 662 & 0,043 \\
\hline $2 \mathrm{~h}$ de envelhec & 0,182 & 0,063 & 0,119 & 65,9 & 231 & 703 & 0,116 \\
\hline $4 \mathrm{~h}$ de envelhec & 0,221 & 0,109 & 0,113 & 57,0 & 202 & 662 & 0,110 \\
\hline
\end{tabular}

Tabela 5.25 - Resultados do ensaio de fluência por compressão uniaxial estática das misturas com AMP PG $76-22$.

\begin{tabular}{|c|c|c|c|c|c|c|c|}
\hline Condição & $\begin{array}{c}\text { Deformação } \\
\text { Total } \\
(\%)\end{array}$ & $\begin{array}{c}\text { Deformação } \\
\text { não Recup. } \\
\text { (\%) }\end{array}$ & $\begin{array}{c}\text { Deformação } \\
\text { Recup. } \\
\text { (\%) }\end{array}$ & $\begin{array}{c}\text { Recup. } \\
(\%)\end{array}$ & $\begin{array}{c}\text { Mf } \\
\text { t=3600 s } \\
\text { (MPa) }\end{array}$ & $\begin{array}{c}\text { Mf } \\
\text { t=4500 s } \\
\text { (MPa) }\end{array}$ & Inclinação \\
\hline Sem envelhec & 0,215 & 0,042 & 0,173 & 80,4 & 192 & 1403 & 0,025 \\
\hline $2 \mathrm{~h}$ de envelhec & 0,258 & 0,069 & 0,190 & 73,7 & 162 & 642 & 0,030 \\
\hline $4 \mathrm{~h}$ de envelhec & 0,238 & 0,100 & 0,138 & 60,1 & 175 & 515 & 0,065 \\
\hline
\end{tabular}

Little, Button, e Youssef (1993) propuseram como critério para avaliação do potencial de deformação permanente do concreto asfáltico a Tabela 5.26, baseada na deformação total após uma hora de carregamento, e na inclinação da curva de fluência no estágio de deformação constante, para ensaios realizados com pressão de $6,9 \mathrm{kgf} / \mathrm{cm}^{2}$. 
Tabela 5.26 - Critério para controle da deformação através de valores obtidos no ensaio de fluência.

\begin{tabular}{ccccccc}
\hline $\begin{array}{c}\text { Deformação total } \\
\text { em } \mathbf{1} \text { hora de }\end{array}$ & \multicolumn{5}{c}{ Inclinação da curva de fluência no estágio secundário ou estágio } \\
carregamento (\%) & \multicolumn{5}{c}{ de deformação constante } \\
\cline { 2 - 7 } & $<\mathbf{0 , 1 7}$ & $<\mathbf{0 , 2 0}$ & $<\mathbf{0 , 2 5}$ & $<\mathbf{0 , 3 0}$ & $<\mathbf{0 , 3 5}$ & $<\mathbf{0 , 4 0}$ \\
\hline$<\mathbf{0 , 2 5}$ & $\mathrm{IV}^{2}$ & $\mathrm{IV}^{2}$ & $\mathrm{IV}^{2}$ & $\mathrm{IV}^{2}$ & $\mathrm{IV}^{2}$ & $\mathrm{III}$ \\
$<\mathbf{0 , 4 0}$ & $\mathrm{IV}^{2}$ & $\mathrm{IV}^{2}$ & $\mathrm{IV}^{2}$ & $\mathrm{III}^{2}$ & $\mathrm{III}^{2}$ & $\mathrm{III}^{2}$ \\
$<\mathbf{0 , 5 0}$ & $\mathrm{IV}^{2}$ & $\mathrm{IV}^{2}$ & $\mathrm{III}^{2}$ & $\mathrm{III}^{2}$ & $\mathrm{III}^{2}$ & $\mathrm{II}$ \\
$<\mathbf{0 , 8 0}$ & $\mathrm{III}^{2}$ & $\mathrm{III}^{2}$ & $\mathrm{II}$ & $\mathrm{II}$ & $\mathrm{II}$ & $\mathrm{II}$ \\
$<\mathbf{1 , 0 0}$ & $\mathrm{I}$ & $\mathrm{I}$ & $\mathrm{I}$ & $\mathrm{I}$ & $\mathrm{I}$ & - \\
$<\mathbf{1 , 2 0}$ & $\mathrm{I}$ & $\mathrm{I}$ & $\mathrm{I}$ & - & - & - \\
\hline
\end{tabular}

- Tráfego de baixa intensidade: $<10^{5}$ operações do eixo padrão.

II - Tráfego de moderada intensidade: $>10^{5}$ e $<5 \times 10^{5}$ op. do eixo padrão.

III - Tráfego de alta intensidade: $>5 \times 10^{5}$ e $<10^{6}$ op. do eixo padrão.

IV - Tráfego de muito alta intensidade: $>10^{6}$ operações do eixo padrão.

$1-$ Deve também ter $\varepsilon_{\mathrm{p}}<0,8 \%$ para 1800 segundos de carregamento.

$2-$ Deve, se possível, seguir o seguinte critério: $\varepsilon_{\mathrm{rt}}+\varepsilon_{\mathrm{p}}<0,5 \varepsilon_{\mathrm{qu}}$, em que $\varepsilon_{\mathrm{p}}$ é a deformação permanente no final do carregamento, $\varepsilon_{\mathrm{rt}}$ é a deformação resiliente total obtido no ensaio de módulo resiliente uniaxial e $\varepsilon_{\text {qu }}$ é a deformação obtida no ensaio de compressão não-confinada, conforme ASTM T 167

Fonte: Little, Button e Youssef (1993)

Porém, os mesmos autores recomendam fazer os ensaios com pressões entre 3,5 a 4,15 $\mathrm{kgf} / \mathrm{cm}^{2}$. Tendo em consideração que a pressão de aplicação de carga utilizada no ensaio foi de $4 \mathrm{kgf} / \mathrm{cm}^{2}$, todos os ligantes asfálticos são capazes de suportar um tráfego de muito alta intensidade (IV), já que para todas as condições de envelhecimento têm uma inclinação da curva de fluência no estágio secundário ou estágio de deformação constante menor que 0,17 e deformação total em uma hora de carregamento menor a 0,25 , com exceção das misturas com CAP PEN 60/70 para 4 horas de envelhecimento e AMP PG 76 -22 para 2 horas de envelhecimento, que apresentaram uma deformação total de 0,270 e 0,258 respetivamente, porém, menor que o especificado de $(0,40)$. Conclui-se que os asfaltos da pesquisa, para todas 
as condições de envelhecimento, são capazes de suportar um tráfego de muito alta intensidade (> a $10^{6}$ operações de eixo padrão).

As Figuras 5.43, 5.44 e 5.45 apresentam os valores de deformações total, não recuperável e recuperável dos ensaios realizados em amostras sem envelhecimento, com 2 horas de envelhecimento e com 4 horas de envelhecimento.

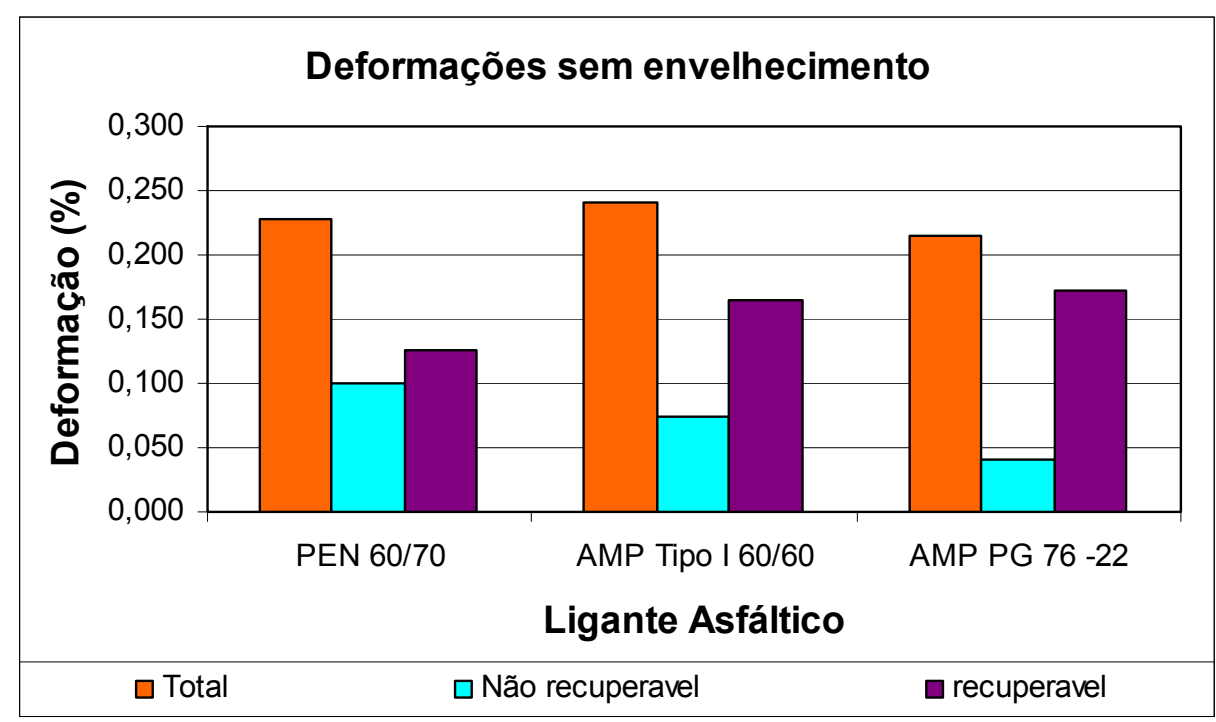

Figura 5.43 - Variação das deformações em amostras sem envelhecimento.

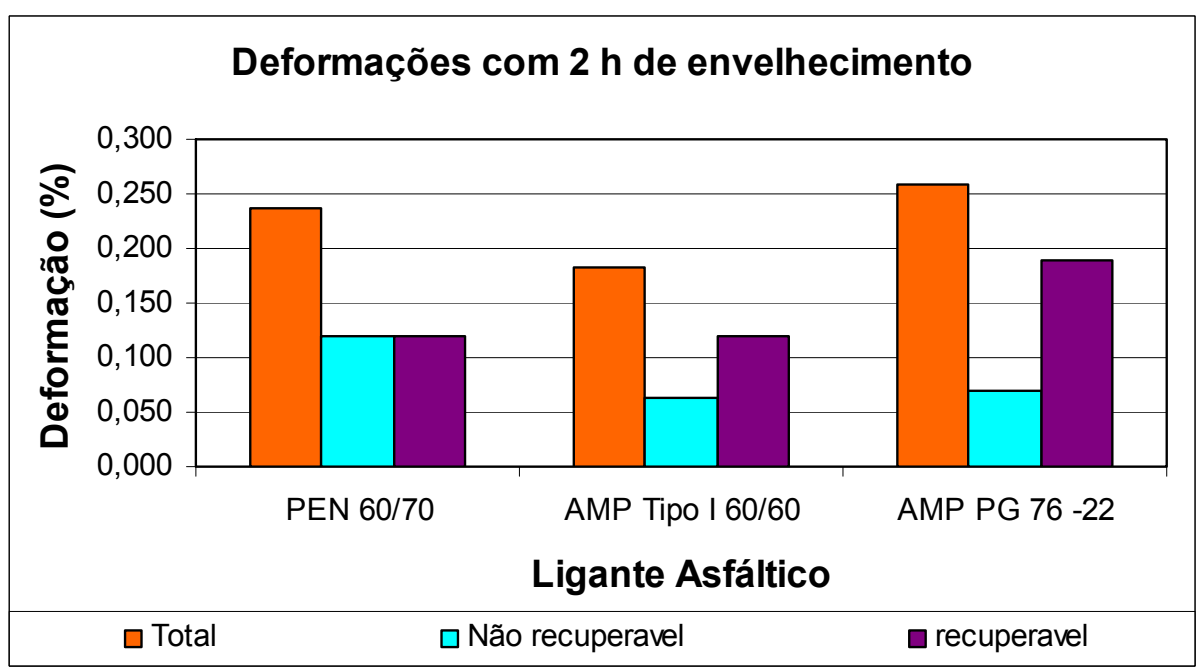

Figura 5.44 - Variação das deformações em amostras com 2 horas de envelhecimento. 


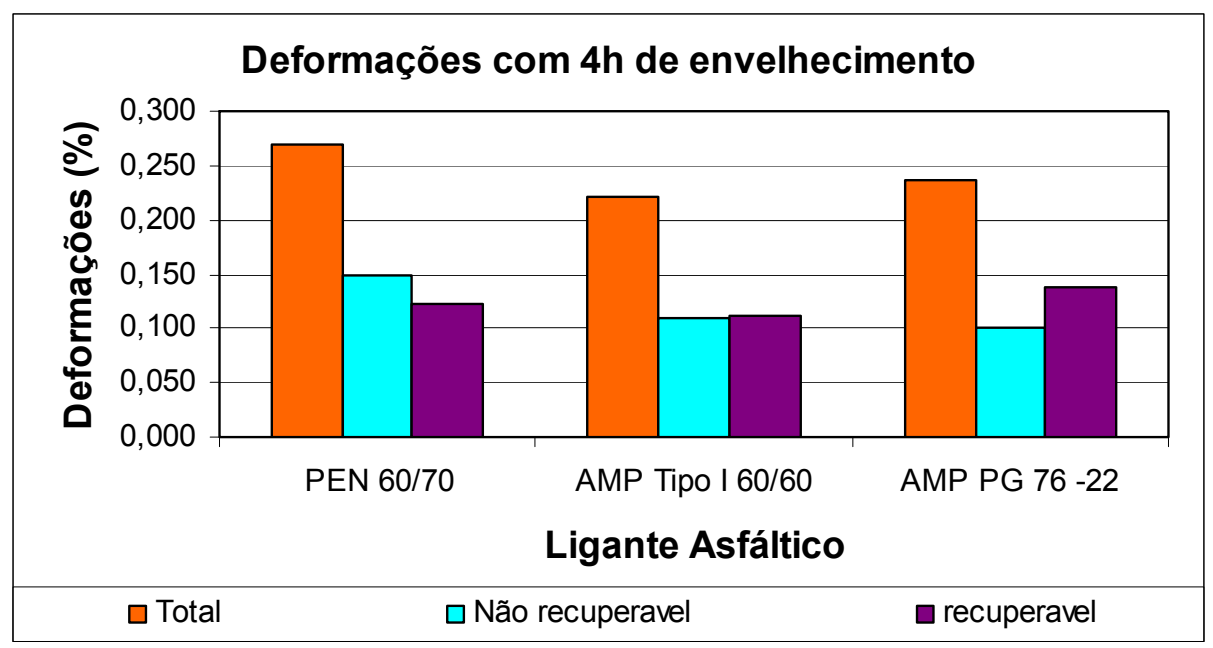

Figura 5.45 - Variação das deformações em amostras com 4 horas de envelhecimento.

Em termos de deformação total, deformação não recuperável e deformação recuperável, para todas as condições de envelhecimento, as deformações totais foram variáveis, porém, os asfaltos modificados por polímeros apresentaram as menores deformações não recuperáveis e as maiores porcentagens de recuperação elástica, evidenciando assim o potencial de recuperação elástica dos asfaltos modificados por polímeros, como se observa na Figura 5.46.

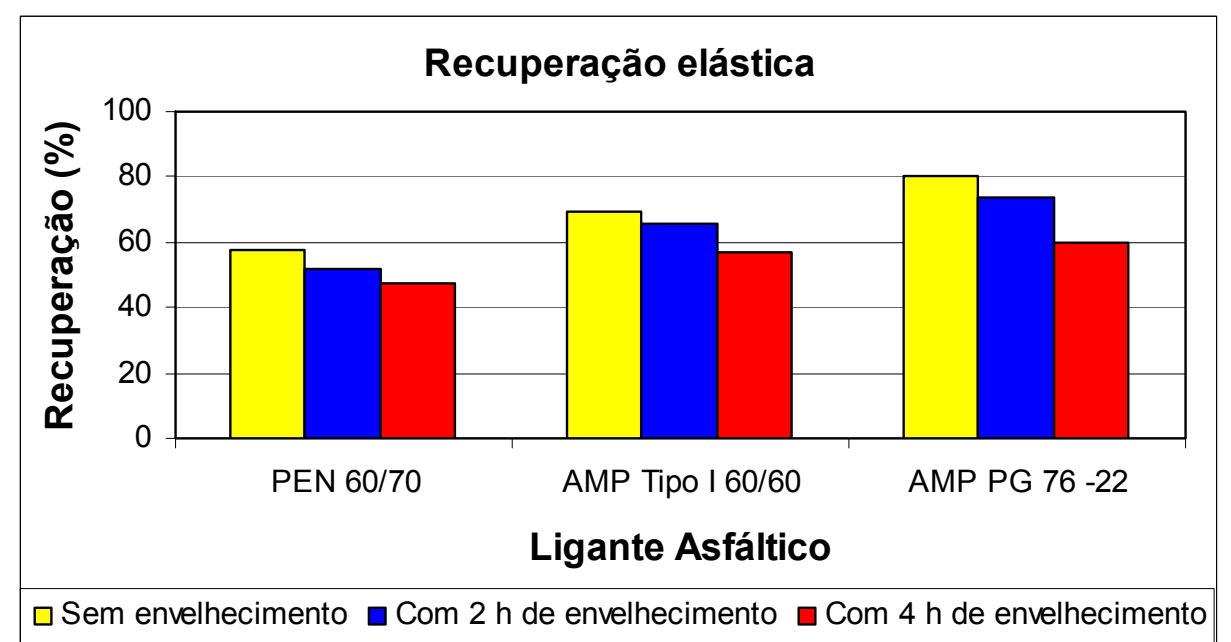

Figura 5.46 - Variação da recuperação elástica em função da condição de envelhecimento. 
Little, Button, e Youssef (1993) também estabelecem como parâmetro de avaliação da deformação permanente do concreto asfáltico o critério de módulo de fluência que é examinado através da Tabela 5.27.

Tabela 5.27 - Critério do módulo de fluência para 1 hora de carregamento.

\begin{tabular}{ccccc}
\hline \multirow{2}{*}{$\begin{array}{c}\text { Resistência à formação de } \\
\text { trilhas de rodas }\end{array}$} & $\begin{array}{c}\text { Nível de intensidade de } \\
\text { tráfego }\end{array}$ & \multicolumn{3}{c}{$\begin{array}{c}\text { Modulo de fluência mínimo (MPa), para } \\
\text { ensaio de tensão constante de: }\end{array}$} \\
\cline { 2 - 5 } & IV & 103,4 & 120,7 & 155,1 \\
\multirow{2}{*}{ Alta } & III & 48,3 & 69,0 & 96,5 \\
& II & 34,5 & 44,8 & 60,3 \\
& I & 20,7 & 27,6 & 41,4 \\
\hline \multirow{2}{*}{ Moderada } & IV & 51,7 & 69,0 & 96,5 \\
& III & 34,5 & 50,0 & 96,0 \\
& II & 24,1 & 41,4 & 51,7 \\
& I & 17,2 & 20,7 & 27,6 \\
\hline
\end{tabular}

I $\quad$ - Tráfego de baixa intensidade: $<10^{5}$ solicitações do eixo padrão

II $\quad-$ Tráfego de moderada intensidade: $10^{5}<$ solicitações do eixo padrão $<5 \times 10^{5}$

III - Tráfego de alta intensidade: $5 \times 10^{5}<$ solicitações do eixo padrão $<10^{6}$

IV - Tráfego de muito alta intensidade: $>10^{6}$ solicitações do eixo padrão

Fonte: Little, Button e Youssef (1993)

Ao se considerar o critério de módulo de fluência mínimo para 1 hora de carregamento em ensaio de tensão constante de 0,483 $\mathrm{MPa}$, verificou-se que todos os ligantes asfálticos, em todas as condições de envelhecimento, foram capazes de suportar um tráfego de muito alta intensidade $\left(>10^{6}\right.$ operações de eixo padrão - IV), pois todos os módulos de fluência foram maiores a 155,1 MPa, embora o ensaio tinha sido realizado com menor tensão (0,4 MPa).

As Figuras 5.47 e 5.48 apresentam os valores do módulo de fluência, que corresponde à relação entre a tensão aplicada e a deformação sofrida, aos 3600 s (somente carregamento) e 
aos $4500 \mathrm{~s}$ (ensaio completo) dos ensaios realizados em amostras sem envelhecimento, com 2 horas de envelhecimento e com 4 horas de envelhecimento.

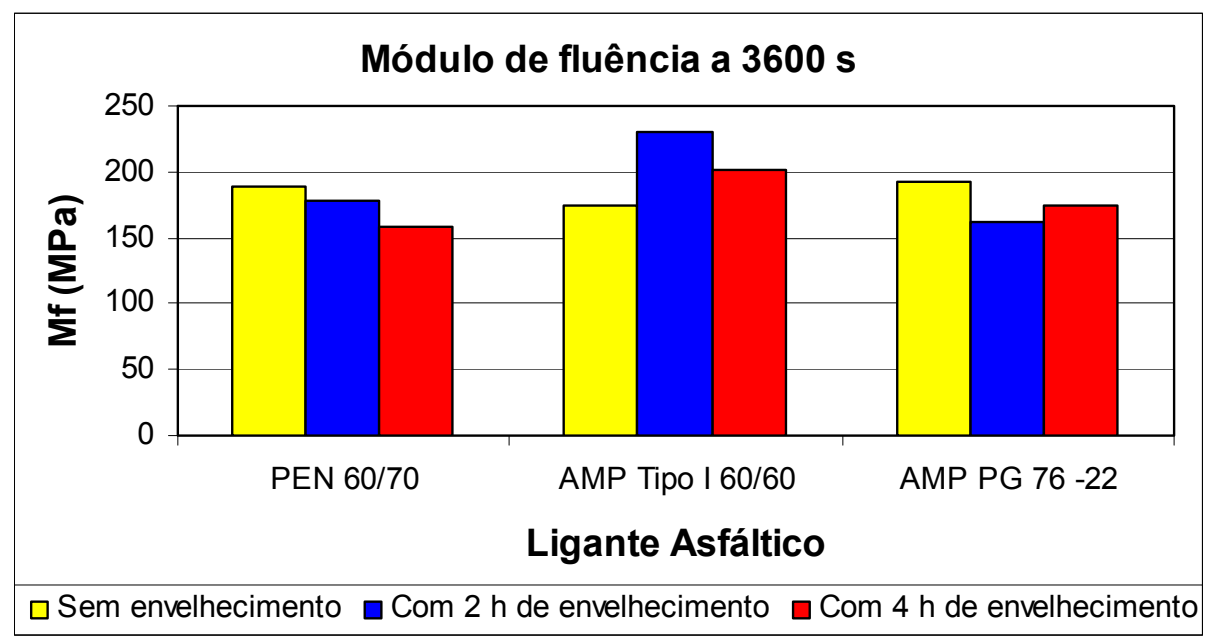

Figura 5.47 - Variação do módulo de fluência a 3600 segundos em função da condição de envelhecimento.

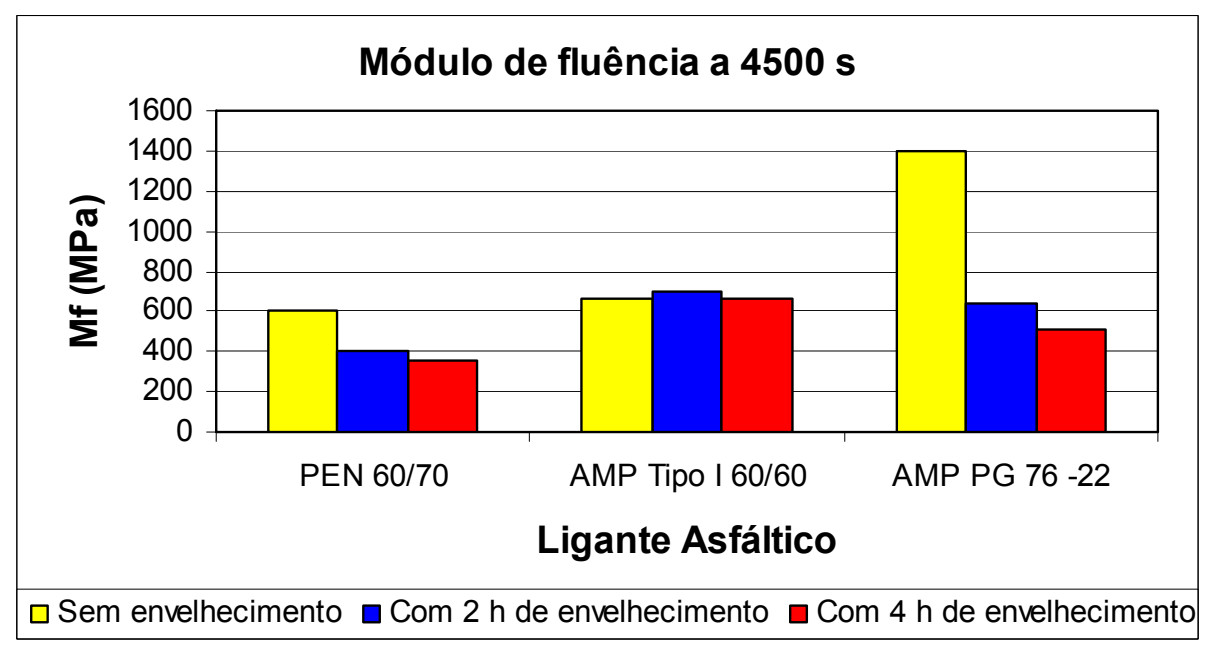

Figura 5.48 - Variação do módulo de fluência a 4500 segundos em função da condição de envelhecimento.

Quanto ao módulo de fluência, o comportamento dos três ligantes asfálticos é semelhante, ou seja, os resultados não distinguem claramente o efeito da adição de polímeros ao asfalto. 
Porém, o módulo de fluência a 4500 segundos, apresentado na Figura 5.48, mostrou que os AMP apresentam resultados maiores que o CAP convencional.

A inclinação média da curva de fluência, obtida através do gráfico de deformação em função do tempo, em escala log-log, mostra a velocidade com que a fluência ocorre, ou seja, o comportamento de uma mistura asfáltica é melhor quanto menor a inclinação. Conforme apresentado na Figura 5.49, os asfaltos modificados por polímeros, apresentaram ser mais resistentes à deformação permanente.

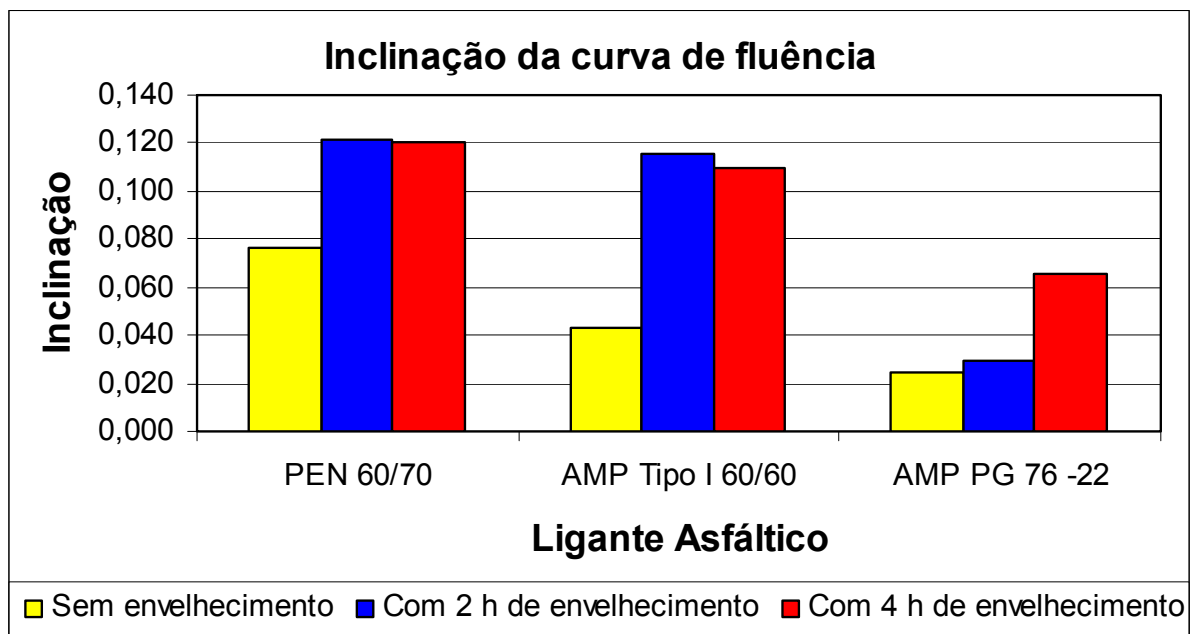

Figura 5.49 - Variação da inclinação em função da condição de envelhecimento.

\subsubsection{Ensaio de fluência por compressão uniaxial dinâmica ("creep dinâmico")}

Os resultados dos ensaios de fluência por compressão uniaxial dinâmica das misturas asfálticas convencional e modificada por polímero são apresentados nas Tabelas 5.28, 5.29 e 5.30, que trazem os valores da deformação final, inclinação entre $100 \mathrm{~s}$ e $5000 \mathrm{~s}$, e módulo de fluência a $5000 \mathrm{~s}$. 
Tabela 5.28 - Resultados do ensaio de fluência por compressão uniaxial dinâmica das misturas com CAP PEN 60/70.

\begin{tabular}{cccc}
\hline Condição & $\begin{array}{c}\text { Deformação Total } \\
\text { (\%) }\end{array}$ & Inclinação & $\begin{array}{c}\text { Módulo de fluência } \\
\text { (MPa) }\end{array}$ \\
\hline Sem envelhecimento & 0,315 & 0,237 & 146 \\
Com 2 h. de envelhecimento & 0,170 & 0,207 & 271 \\
Com 4 h. de envelhecimento & 0,131 & 0,179 & 331 \\
\hline
\end{tabular}

Tabela 5.29 - Resultados do ensaio de fluência por compressão uniaxial dinâmica das misturas com AMP Tipo I 60/60.

\begin{tabular}{cccc}
\hline Condição & $\begin{array}{c}\text { Deformação Total } \\
\text { (\%) }\end{array}$ & Inclinação & $\begin{array}{c}\text { Módulo de fluência } \\
\text { (MPa) }\end{array}$ \\
\hline Sem envelhecimento & 0,180 & 0,132 & 240 \\
Com 2 h. de envelhecimento & 0,098 & 0,125 & 470 \\
Com 4 h. de envelhecimento & 0,082 & 0,107 & 528 \\
\hline
\end{tabular}

Tabela 5.30 - Resultados do ensaio de fluência por compressão uniaxial dinâmica das misturas com AMP PG 76 -22.

\begin{tabular}{cccc}
\hline Condição & $\begin{array}{c}\text { Deformação Total } \\
\text { (\%) }\end{array}$ & Inclinação & $\begin{array}{c}\text { Módulo de fluência } \\
\text { (MPa) }\end{array}$ \\
\hline Sem envelhecimento & 0,194 & 0,124 & 220 \\
Com 2 h. de envelhecimento & 0,100 & 0,126 & 431 \\
Com 4 h. de envelhecimento & 0,098 & 0,127 & 471 \\
\hline
\end{tabular}

As deformações obtidas no final do ensaio de fluência por compressão uniaxial dinâmica, apresentadas na Figura 5.50, mostraram que as misturas com asfalto modificado por polímero SBS têm melhor desempenho em relação ao asfalto convencional PEN 60/70. 


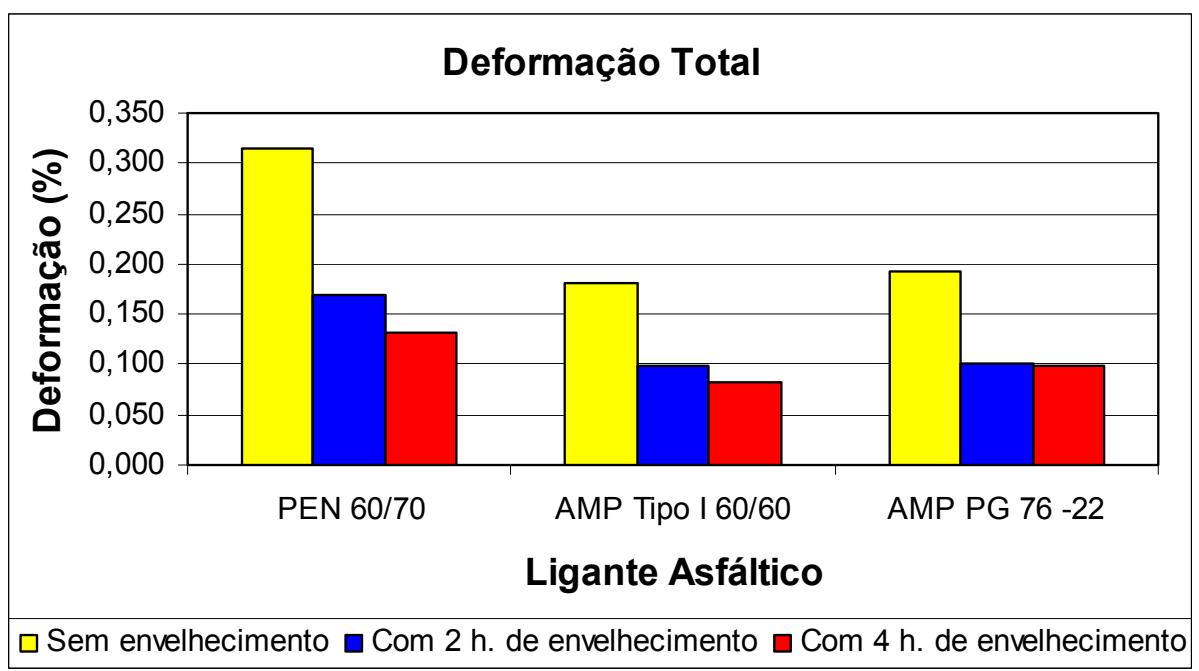

Figura 5.50 - Variação da deformação em função da condição de envelhecimento.

As inclinações médias das curvas de fluência apresentadas na Figura 5.51 também apresentam claramente que os AMP apresentam melhor desempenho à deformação permanente para todas as condições de envelhecimento.

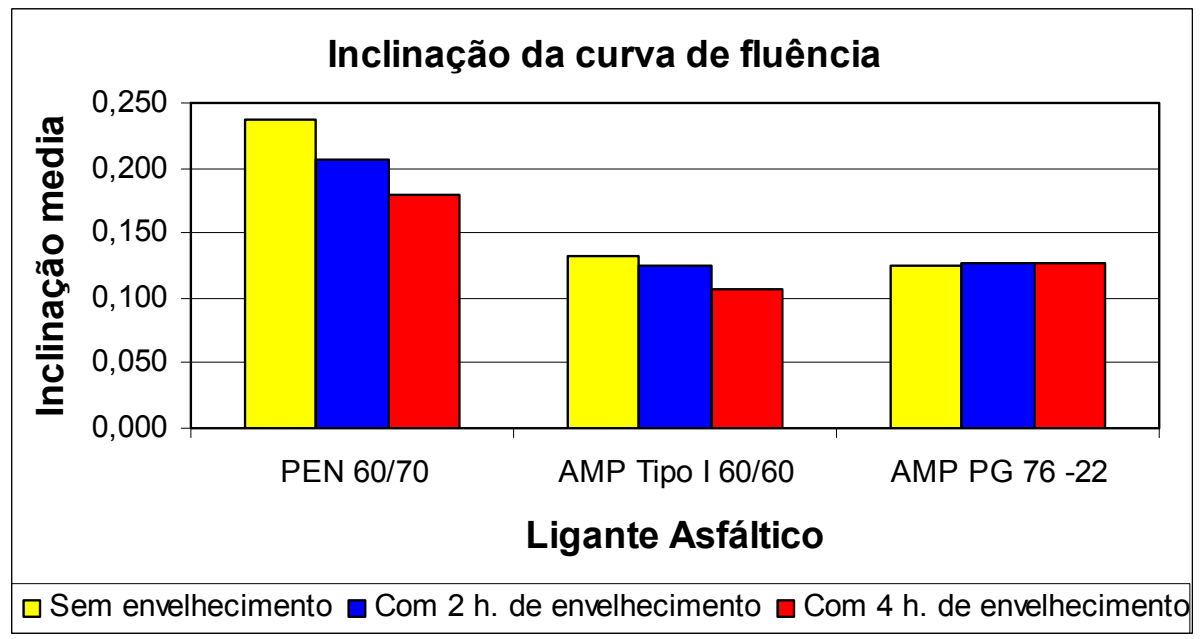

Figura 5.51 - Variação da inclinação da curva de fluência em função da condição de envelhecimento.

Para os valores de módulo de fluência por compressão uniaxial dinâmica mostrados nas Tabelas 5.28 a 5.30 observou-se que quanto maior o módulo de fluência dinâmica menor é a 
deformação permanente sofrida pelo corpo de prova. Os resultados mostraram que os asfaltos modificados por polímeros apresentaram os maiores valores de módulo de fluência para todas as condições de envelhecimento (Figura 5.52). Para todos os parâmetros de avaliação os AMP apresentam melhor desempenho à deformação permanente que o CAP convencional. Mostrando-se que o ensaio de fluência por compressão uniaxial dinâmica avalia melhor o comportamento à deformação permanente das misturas asfálticas modificadas por polímero.

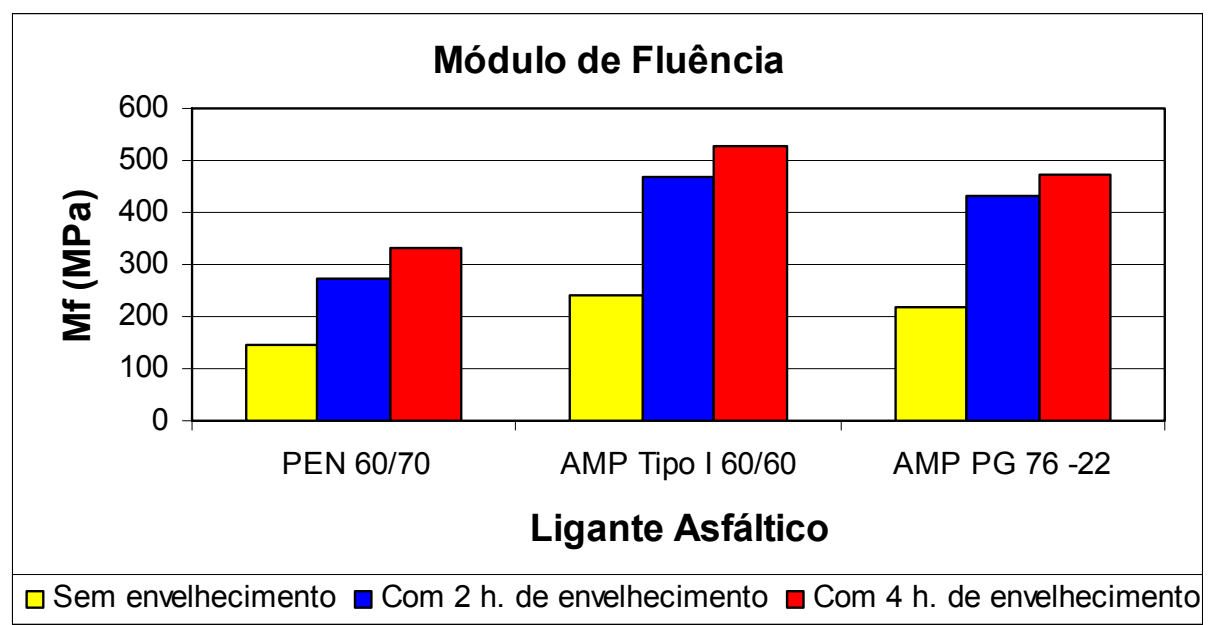

Figura 5.52 - Variação do módulo de fluência em função da condição de envelhecimento.

\subsubsection{Ensaio de vida de fadiga}

A vida de fadiga foi determinada através do ensaio de compressão diametral sob tensão controlada e o critério de ruptura foi, a ruptura propriamente dita ou um deslocamento vertical acumulado do corpo-de-prova de $6 \mathrm{~mm}$. A vida de fadiga é expressa em função da diferença de tensões $(\Delta \sigma)$, entre a tensão de tração e de compressão, e em função do parâmetro de deformação resiliente (ci), calculado através das expressões (4.27 e 4.28). As Tabelas 5.31, 5.32 e 5.33 apresentam os resultados dos ensaios de fadiga e os modelos de fadiga para as misturas com CAP PEN 60/70, sem envelhecimento e com envelhecimento em curto prazo. 
São apresentados em cada tabela os modelos de fadiga em função da diferença de tensões e da deformação resiliente calculada.

Tabela 5.31 - Vida de Fadiga das misturas com CAP PEN 60/70 sem envelhecimento.

\begin{tabular}{|c|c|c|c|c|c|}
\hline \multicolumn{6}{|c|}{ CAP PEN 60/70 - Sem Envelhecimento } \\
\hline \multicolumn{2}{|c|}{$\mathbf{R T}=\mathbf{0 , 9 7}$} & \multicolumn{4}{|c|}{$M R=2135$} \\
\hline $\mathbf{C P}$ & Carga $(\mathbf{N})$ & $\%$ RT & $\Delta \sigma(\mathrm{MPa})$ & $\mathbf{\varepsilon i}$ & $\mathbf{N}$ \\
\hline CP-P-051 & 4120 & $44,95 \%$ & 1,74 & $2,038 \mathrm{E}-04$ & 330 \\
\hline CP-P-047 & 4120 & $45,15 \%$ & 1,75 & $2,047 \mathrm{E}-04$ & 254 \\
\hline CP-P-041 & 3660 & $40,24 \%$ & 1,56 & $1,825 \mathrm{E}-04$ & 642 \\
\hline CP-P-049 & 3660 & $40,34 \%$ & 1,56 & $1,829 \mathrm{E}-04$ & 667 \\
\hline CP-P-042 & 2740 & $29,85 \%$ & 1,16 & $1,354 \mathrm{E}-04$ & 1694 \\
\hline CP-P-044 & 2740 & $29,92 \%$ & 1,16 & $1,357 \mathrm{E}-04$ & 1491 \\
\hline CP-P-048 & 1830 & $20,12 \%$ & 0,78 & $9,121 \mathrm{E}-05$ & 13116 \\
\hline CP-P-043 & 1830 & $20,07 \%$ & 0,78 & 9,099E-05 & 8764 \\
\hline \multirow{2}{*}{\multicolumn{3}{|c|}{ Modelos de Fadiga }} & \multicolumn{3}{|c|}{$\mathrm{N}=3490,8(1 / \Delta \sigma)^{4,2683}$} \\
\hline & & & \multicolumn{3}{|c|}{$\mathrm{N}=6,0 \times 10^{-14}(1 / \varepsilon \mathrm{i})^{4,2683}$} \\
\hline
\end{tabular}

Tabela 5.32 - Vida de Fadiga das misturas com CAP PEN 60/70 com 2 h de envelhecimento.

\begin{tabular}{|c|c|c|c|c|c|}
\hline \multicolumn{6}{|c|}{ CAP PEN 60/70 - Com 2 h de Envelhecimento } \\
\hline \multicolumn{2}{|c|}{$\mathrm{RT}=1,29$} & \multicolumn{4}{|c|}{$M R=4423$} \\
\hline $\mathbf{C P}$ & $\operatorname{Carga}(\mathbf{N})$ & $\%$ RT & $\Delta \sigma(\mathbf{M P a})$ & $\varepsilon \mathbf{i}$ & $\mathbf{N}$ \\
\hline CP-P-023 & 5420 & $44,98 \%$ & 2,33 & $1,316 \mathrm{E}-04$ & 1224 \\
\hline CP-P-022 & 5420 & $45,14 \%$ & 2,34 & $1,320 \mathrm{E}-04$ & 581 \\
\hline CP-P-019 & 4810 & $39,88 \%$ & 2,06 & $1,167 \mathrm{E}-04$ & 1118 \\
\hline CP-P-025 & 4810 & $40,36 \%$ & 2,09 & $1,181 \mathrm{E}-04$ & 992 \\
\hline CP-P-021 & 3610 & $30,14 \%$ & 1,56 & $8,816 \mathrm{E}-05$ & 4529 \\
\hline CP-P-027 & 3610 & $30,13 \%$ & 1,56 & $8,814 \mathrm{E}-05$ & 5088 \\
\hline CP-P-016 & 2410 & $19,88 \%$ & 1,03 & $5,816 \mathrm{E}-05$ & 22295 \\
\hline CP-P-020 & 2410 & $20,09 \%$ & 1,04 & $5,876 \mathrm{E}-05$ & 21844 \\
\hline \multirow{2}{*}{\multicolumn{3}{|c|}{ Modelos de Fadiga }} & \multicolumn{3}{|c|}{$\mathrm{N}=26600(1 / \Delta \sigma)^{4,1743}$} \\
\hline & & & \multicolumn{3}{|c|}{$\mathrm{N}=5,0 \times 10^{-14}(1 / \varepsilon \mathrm{i})^{4,1743}$} \\
\hline
\end{tabular}


Tabela 5.33 - Vida de Fadiga das misturas com CAP PEN 60/70 com 4 h de envelhecimento.

\begin{tabular}{|c|c|c|c|c|c|}
\hline \multicolumn{6}{|c|}{ CAP PEN 60/70 - Com $4 \mathrm{~h}$ de Envelhecimento } \\
\hline \multicolumn{2}{|c|}{$\mathrm{RT}=1,58$} & \multicolumn{4}{|c|}{$M R=5750$} \\
\hline $\mathbf{C P}$ & Carga (N) & $\%$ RT & $\Delta \sigma(\mathrm{MPa})$ & $\boldsymbol{\varepsilon i}$ & $\mathbf{N}$ \\
\hline CP-P-033 & 6620 & $45,08 \%$ & 2,86 & $1,241 \mathrm{E}-04$ & 636 \\
\hline CP-P-028 & 6620 & $44,92 \%$ & 2,85 & $1,237 \mathrm{E}-04$ & 507 \\
\hline CP-P-032 & 5890 & $39,67 \%$ & 2,51 & $1,092 \mathrm{E}-04$ & 909 \\
\hline CP-P-034 & 5890 & $39,63 \%$ & 2,51 & $1,091 \mathrm{E}-04$ & 697 \\
\hline CP-P-036 & 4420 & $30,10 \%$ & 1,91 & $8,288 \mathrm{E}-05$ & 3352 \\
\hline CP-P-039 & 4420 & $30,04 \%$ & 1,90 & $8,274 \mathrm{E}-05$ & 3099 \\
\hline CP-P-038 & 2940 & $19,95 \%$ & 1,26 & $5,494 \mathrm{E}-05$ & 27119 \\
\hline CP-P-031 & 2940 & $20,00 \%$ & 1,27 & $5,509 \mathrm{E}-05$ & 28270 \\
\hline \multirow{2}{*}{\multicolumn{3}{|c|}{ Modelos de Fadiga }} & \multicolumn{3}{|c|}{$\mathrm{N}=82292(1 / \Delta \sigma)^{4,8964}$} \\
\hline & & & \multicolumn{3}{|c|}{$\mathrm{N}=4,0 \times 10^{-17}(1 / \varepsilon \mathrm{i})^{4,8964}$} \\
\hline
\end{tabular}

As Figuras 5.53 e 5.54 apresentam as curvas de fadiga para as misturas com CAP PEN 60/70, sem envelhecimento e com envelhecimento em curto prazo, onde se apresenta o coeficiente de determinação $\mathrm{R}^{2}$ correspondente à qualidade do ajuste do modelo. Os três modelos apresentaram valores altos de $\mathrm{R}^{2}$.

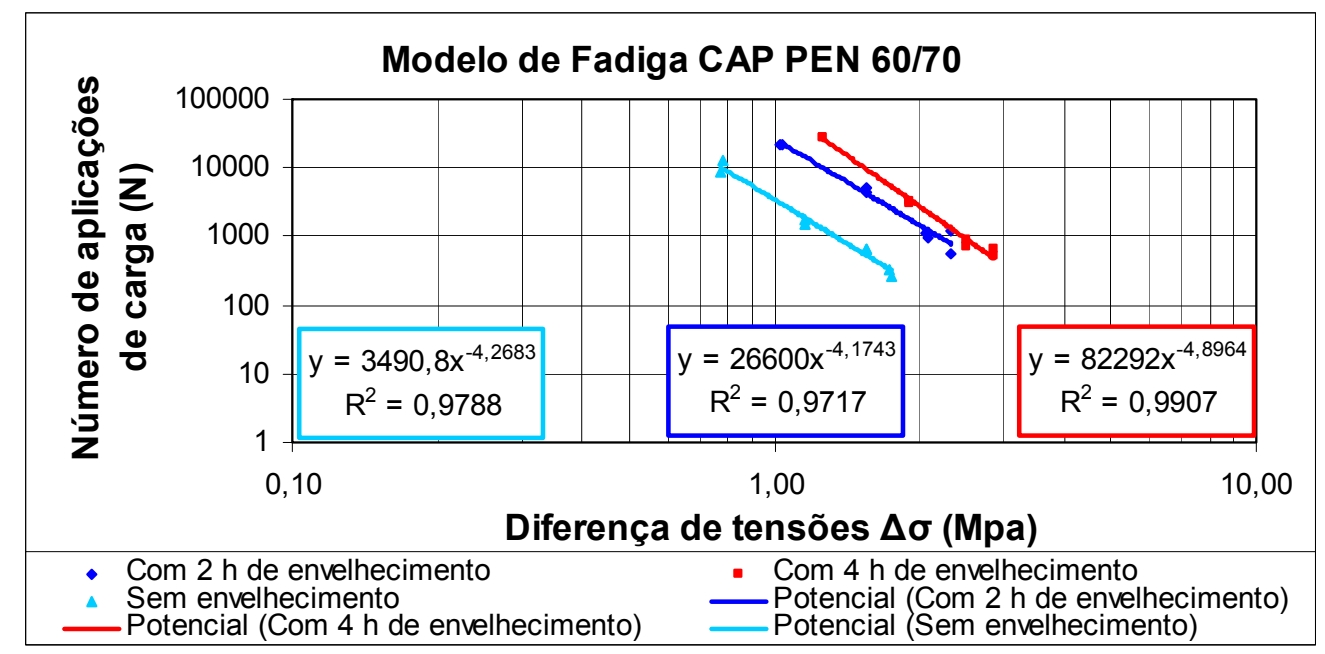

Figura 5.53 - Curvas de Fadiga em função da diferença de tensões para CAP PEN 60/70. 


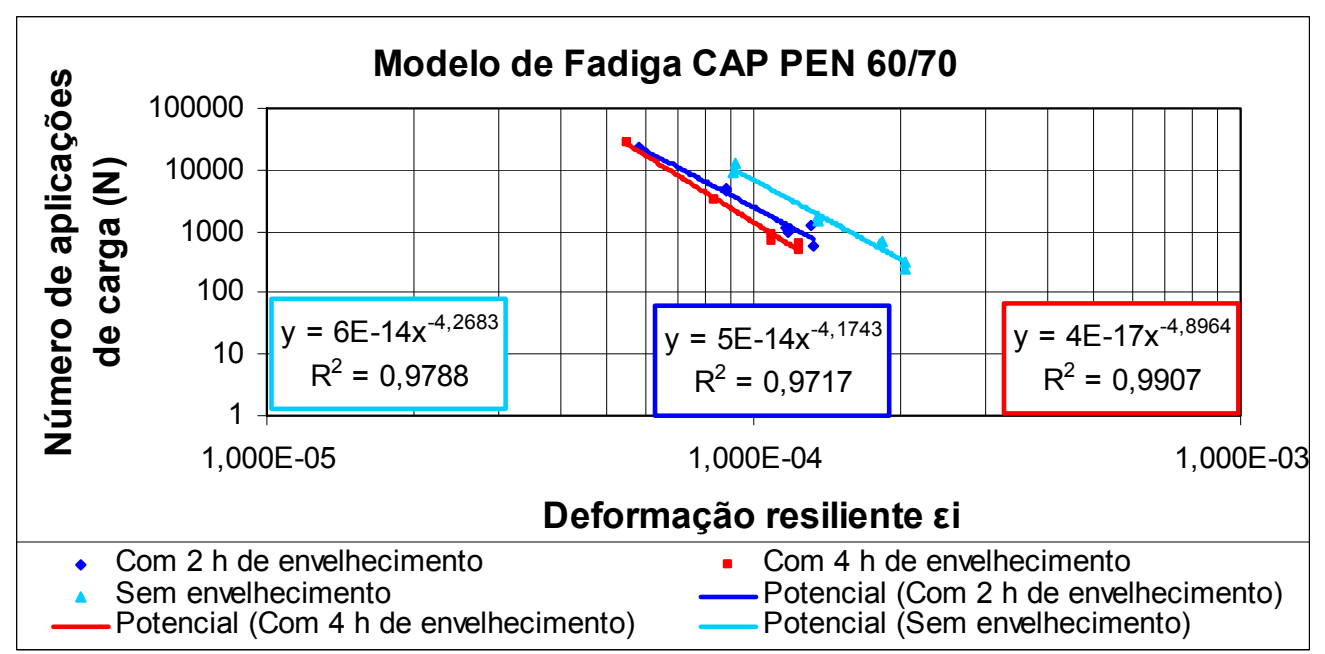

Figura 5.54 - Curvas de Fadiga em função da deformação resiliente para CAP PEN 60/70.

Os valores do coeficiente k2, que indicam a inclinação da curva, variam de 4,17 a 4,89, resultados que se encontram dentro do intervalo de 1,58 a 7,1 citado por Monismith et al. (1990). A figura 5.53 mostra que para o mesmo valor de diferença de tensões as misturas com 4 horas de envelhecimento apresentam maiores valores de N. Porém, a Figura 5.54 mostra que para uma mesma deformação resiliente as misturas sem envelhecimento apresentam os maiores valores de $\mathrm{N}$.

As Tabelas 5.34, 5.35 e 5.36 apresentam os resultados dos ensaios de fadiga e os modelos obtidos para as misturas com AMP Tipo I 60/60, sem envelhecimento e com envelhecimento em curto prazo. Em cada tabela são apresentados dois modelos de fadiga, em função da diferença de tensão e da deformação resiliente calculada. 
Tabela 5.34 - Vida de Fadiga das misturas com AMP Tipo I 60/60 sem envelhecimento.

\begin{tabular}{|c|c|c|c|c|c|}
\hline \multicolumn{6}{|c|}{ AMP Tipo I 60/60 - Sem Envelhecimento } \\
\hline \multicolumn{2}{|c|}{$\mathrm{RT}=1,21$} & \multicolumn{4}{|c|}{$M R=2335$} \\
\hline $\mathbf{C P}$ & Carga $(N)$ & $\%$ RT & $\Delta \sigma(\mathbf{M P a})$ & $\boldsymbol{\varepsilon i}$ & $\mathbf{N}$ \\
\hline CP-B-044 & 5130 & $45,26 \%$ & 2,20 & $2,351 \mathrm{E}-04$ & 367 \\
\hline CP-B-047 & 5130 & $44,83 \%$ & 2,17 & $2,329 \mathrm{E}-04$ & 346 \\
\hline CP-B-050 & 4560 & $39,79 \%$ & 1,93 & $2,067 \mathrm{E}-04$ & 746 \\
\hline CP-B-040 & 4560 & $39,29 \%$ & 1,91 & $2,041 \mathrm{E}-04$ & 482 \\
\hline CP-B-042 & 3420 & $30,12 \%$ & 1,46 & $1,564 \mathrm{E}-04$ & 2111 \\
\hline CP-B-045 & 3420 & $29,84 \%$ & 1,45 & $1,550 \mathrm{E}-04$ & 2202 \\
\hline CP-B-051 & 2280 & $19,89 \%$ & 0,97 & $1,033 \mathrm{E}-04$ & 20911 \\
\hline CP-B-049 & 2280 & $19,93 \%$ & 0,97 & $1,035 \mathrm{E}-04$ & 11410 \\
\hline \multirow{2}{*}{\multicolumn{3}{|c|}{ Modelos de Fadiga }} & \multicolumn{3}{|c|}{$\mathrm{N}=12779(1 / \Delta \sigma)^{4,6417}$} \\
\hline & & & \multicolumn{3}{|c|}{$\mathrm{N}=5,0 \times 10^{-15}(1 / \varepsilon \mathrm{i})^{4,6417}$} \\
\hline
\end{tabular}

Tabela 5.35 - Vida de Fadiga das misturas com AMP Tipo I 60/60 com 2 h de envelhecimento.

\begin{tabular}{|c|c|c|c|c|c|}
\hline \multicolumn{6}{|c|}{ AMP Tipo I 60/60 - Com 2 h de Envelhecimento } \\
\hline \multicolumn{2}{|c|}{$\mathrm{RT}=\mathbf{1 , 6 5}$} & \multicolumn{4}{|c|}{$M R=5106$} \\
\hline $\mathbf{C P}$ & $\operatorname{Carga}(\mathbf{N})$ & $\%$ RT & $\Delta \sigma(\mathbf{M P a})$ & $\boldsymbol{\varepsilon i}$ & $\mathbf{N}$ \\
\hline CP-B-021 & 6970 & $45,32 \%$ & 2,99 & $1,466 \mathrm{E}-04$ & 568 \\
\hline CP-B-024 & 6970 & $45,20 \%$ & 2,99 & $1,462 \mathrm{E}-04$ & 491 \\
\hline CP-B-016 & 6200 & $39,97 \%$ & 2,64 & $1,293 \mathrm{E}-04$ & 1035 \\
\hline CP-B-025 & 6200 & $40,07 \%$ & 2,65 & $1,296 \mathrm{E}-04$ & 788 \\
\hline CP-B-018 & 4650 & $30,03 \%$ & 1,98 & $9,712 \mathrm{E}-05$ & 6217 \\
\hline CP-B-027 & 4650 & $30,10 \%$ & 1,99 & $9,736 \mathrm{E}-05$ & 4530 \\
\hline CP-B-019 & 3100 & $19,98 \%$ & 1,32 & $6,464 \mathrm{E}-05$ & 33114 \\
\hline CP-B-020 & 3100 & $20,12 \%$ & 1,33 & $6,506 \mathrm{E}-05$ & 35198 \\
\hline \multirow{2}{*}{\multicolumn{3}{|c|}{ Modelos de Fadiga }} & \multicolumn{3}{|c|}{$\mathrm{N}=158831(1 / \Delta \sigma)^{5,2113}$} \\
\hline & & & \multicolumn{3}{|c|}{$\mathrm{N}=5,0 \times 10^{-18}(1 / \varepsilon \mathrm{i})^{5,2113}$} \\
\hline
\end{tabular}


Tabela 5.36 - Vida de Fadiga das misturas com AMP Tipo I 60/60 com 4 h de envelhecimento.

\begin{tabular}{|c|c|c|c|c|c|}
\hline \multicolumn{6}{|c|}{ AMP Tipo I 60/60 - Com 4 h de Envelhecimento } \\
\hline \multicolumn{2}{|c|}{$\mathbf{R T}=\mathbf{1 , 7 8}$} & \multicolumn{4}{|c|}{$M R=6189$} \\
\hline $\mathbf{C P}$ & Carga $(\mathbf{N})$ & $\%$ RT & $\Delta \sigma(\mathbf{M P a})$ & $\boldsymbol{\varepsilon i}$ & $\mathbf{N}$ \\
\hline CP-B-038 & 7610 & $45,43 \%$ & 3,23 & $1,306 \mathrm{E}-04$ & 521 \\
\hline CP-B-030 & 7610 & $45,73 \%$ & 3,25 & $1,314 \mathrm{E}-04$ & 485 \\
\hline CP-B-037 & 6760 & $40,07 \%$ & 2,85 & $1,152 \mathrm{E}-04$ & 798 \\
\hline CP-B-031 & 6760 & $40,21 \%$ & 2,86 & $1,156 \mathrm{E}-04$ & 619 \\
\hline CP-B-036 & 5070 & $30,32 \%$ & 2,16 & $8,714 \mathrm{E}-05$ & 3761 \\
\hline CP-B-039 & 5070 & $30,29 \%$ & 2,16 & $8,706 \mathrm{E}-05$ & 4103 \\
\hline CP-B-032 & 3380 & $20,14 \%$ & 1,43 & $5,788 \mathrm{E}-05$ & 67446 \\
\hline CP-B-034 & 3380 & $20,27 \%$ & 1,44 & $5,826 \mathrm{E}-05$ & 49492 \\
\hline \multirow{2}{*}{\multicolumn{3}{|c|}{ Modelos de Fadiga }} & \multicolumn{3}{|c|}{$\mathrm{N}=458010(1 / \Delta \sigma)^{5,9932}$} \\
\hline & & & \multicolumn{3}{|c|}{$\mathrm{N}=2,0 \times 10^{-21}(1 / \varepsilon \mathrm{i})^{5,9932}$} \\
\hline
\end{tabular}

As Figuras 5.55 e 5.56 apresentam as curvas de fadiga das misturas sem e com envelhecimento do AMP Tipo I 60/60, em função da diferença de tensões e da deformação resiliente. As misturas com AMP Tipo I 60/60 foram as que obtiveram menores dispersões nos modelos obtidos.

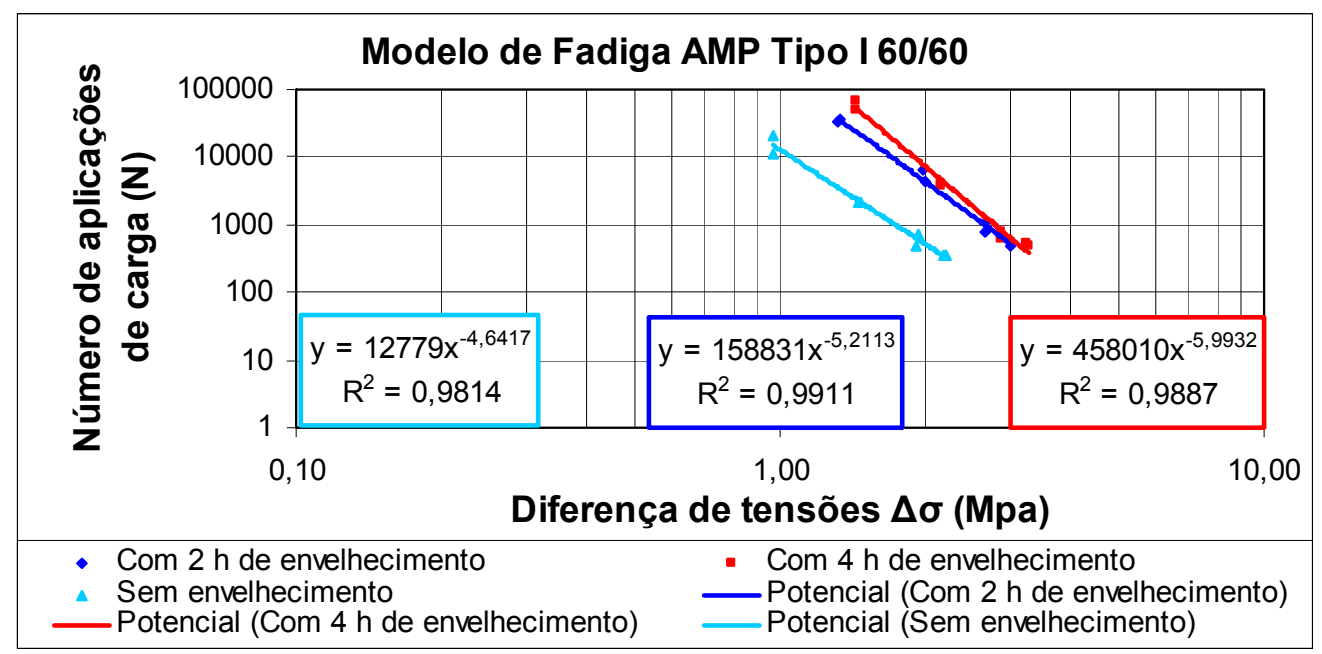

Figura 5.55 - Curvas de Fadiga em função da diferença de tensões para AMP Tipo I 60/60. 


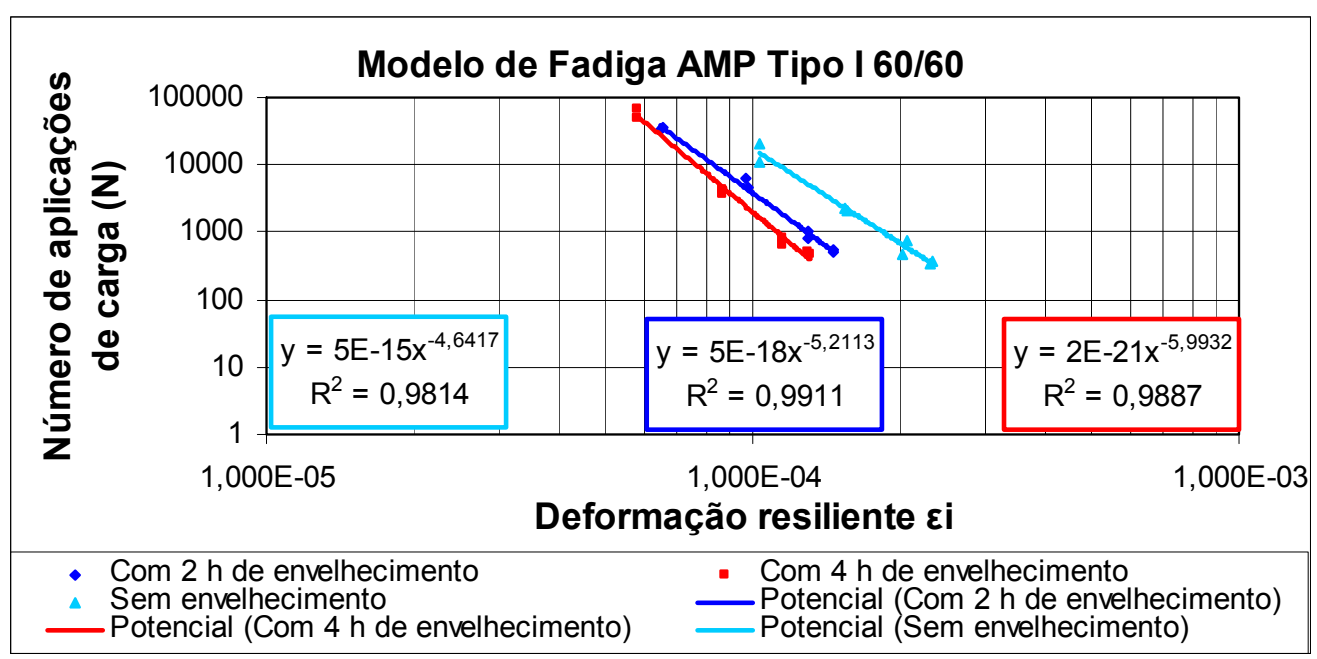

Figura 5.56 - Curvas de Fadiga em função da deformação resiliente para AMP Tipo I 60/60.

A Figura 5.55 mostra que para o mesmo valor de diferença de tensões as misturas com 4 horas de envelhecimento apresentam maiores valores de N. Porém, a Figura 5.56 mostra que para uma mesma deformação resiliente as misturas sem envelhecimento apresentam os maiores valores de $\mathrm{N}$, similar ao caso dos modelos de fadiga do CAP PEN 60/70.

As Tabelas 5.37, 5.38 e 5.39 apresentam os resultados dos ensaios de fadiga e os respectivos modelos obtidos para as misturas com AMP PG 76 -22, sem envelhecimento e com envelhecimento em curto prazo. Em cada tabela são apresentados dois modelos de fadiga, um em função da diferença de tensão e outro em função da deformação resiliente calculada. 
Tabela 5.37 - Vida de Fadiga das misturas com AMP PG 76 -22 sem envelhecimento.

\begin{tabular}{|c|c|c|c|c|c|}
\hline \multicolumn{6}{|c|}{ AMP PG 76 -22 - Sem Envelhecimento } \\
\hline \multicolumn{2}{|c|}{$\mathrm{RT}=1,36$} & \multicolumn{4}{|c|}{$M R=3119$} \\
\hline $\mathbf{C P}$ & Carga $(\mathrm{N})$ & $\%$ RT & $\Delta \sigma(\mathrm{MPa})$ & $\mathbf{\varepsilon i}$ & $\mathbf{N}$ \\
\hline CP-S-041 & 5760 & $45,00 \%$ & 2,44 & $1,955 \mathrm{E}-04$ & 458 \\
\hline CP-S-049 & 5760 & $44,41 \%$ & 2,41 & 1,930E-04 & 313 \\
\hline CP-S-040 & 5120 & $40,32 \%$ & 2,19 & $1,752 \mathrm{E}-04$ & 1013 \\
\hline CP-S-044 & 5120 & $39,91 \%$ & 2,16 & $1,734 \mathrm{E}-04$ & 1030 \\
\hline CP-S-047 & 3840 & $29,99 \%$ & 1,63 & $1,303 \mathrm{E}-04$ & 2084 \\
\hline CP-S-051 & 3840 & $29,93 \%$ & 1,62 & $1,300 \mathrm{E}-04$ & 2000 \\
\hline CP-S-042 & 2560 & $20,21 \%$ & 1,10 & $8,779 \mathrm{E}-05$ & 11762 \\
\hline CP-S-046 & 2560 & $19,92 \%$ & 1,08 & $8,655 \mathrm{E}-05$ & 13151 \\
\hline \multirow{2}{*}{\multicolumn{3}{|c|}{ Modelos de Fadiga }} & \multicolumn{3}{|c|}{$\mathrm{N}=16924(1 / \Delta \sigma)^{4,0476}$} \\
\hline & & & \multicolumn{3}{|c|}{$\mathrm{N}=4,0 \times 10^{-13}(1 / \varepsilon \mathrm{i})^{4,0476}$} \\
\hline
\end{tabular}

Tabela 5.38 - Vida de Fadiga das misturas com AMP PG 76 -22 com 2 h de envelhecimento.

\begin{tabular}{|c|c|c|c|c|c|}
\hline \multicolumn{6}{|c|}{ AMP PG 76 -22 - Com 2 h de Envelhecimento } \\
\hline \multicolumn{2}{|c|}{$\mathbf{R T}=1,90$} & \multicolumn{4}{|c|}{$M R=6525$} \\
\hline $\mathbf{C P}$ & Carga (N) & $\%$ RT & $\Delta \sigma(\mathrm{MPa})$ & $\varepsilon \mathbf{i}$ & $\mathbf{N}$ \\
\hline CP-S-016 & 7950 & $45,18 \%$ & 3,44 & $1,318 \mathrm{E}-04$ & 701 \\
\hline CP-S-021 & 7950 & $45,30 \%$ & 3,45 & $1,322 \mathrm{E}-04$ & 1059 \\
\hline CP-S-027 & 7070 & $40,28 \%$ & 3,07 & $1,175 \mathrm{E}-04$ & 1370 \\
\hline CP-S-022 & 7070 & $40,25 \%$ & 3,07 & $1,174 \mathrm{E}-04$ & 1552 \\
\hline CP-S-024 & 5300 & $30,04 \%$ & 2,29 & $8,767 \mathrm{E}-05$ & 10880 \\
\hline CP-S-019 & 5300 & $30,33 \%$ & 2,31 & $8,850 \mathrm{E}-05$ & 6027 \\
\hline CP-S-017 & 3540 & $20,10 \%$ & 1,53 & $5,864 \mathrm{E}-05$ & 44655 \\
\hline CP-S-026 & 3540 & $20,13 \%$ & 1,53 & $5,874 \mathrm{E}-05$ & 43231 \\
\hline \multirow{2}{*}{\multicolumn{3}{|c|}{ Modelos de Fadiga }} & \multicolumn{3}{|c|}{$\mathrm{N}=395175(1 / \Delta \sigma)^{4,9262}$} \\
\hline & & & \multicolumn{3}{|c|}{$\mathrm{N}=7,0 \times 10^{-17}(1 / \varepsilon \mathrm{i})^{4,9262}$} \\
\hline
\end{tabular}


Tabela 5.39 - Vida de Fadiga das misturas com AMP PG 76 -22 com 4 h de envelhecimento.

\begin{tabular}{|c|c|c|c|c|c|}
\hline \multicolumn{6}{|c|}{ AMP PG 76 -22 - Com 4 h de Envelhecimento } \\
\hline \multicolumn{2}{|c|}{$\mathbf{R T}=1,92$} & \multicolumn{4}{|c|}{$\mathrm{MR}=5521$} \\
\hline $\mathbf{C P}$ & Carga $(N)$ & $\%$ RT & $\Delta \sigma(\mathbf{M P a})$ & $\mathbf{\varepsilon i}$ & $\mathbf{N}$ \\
\hline CP-S-033 & 8040 & $45,00 \%$ & 3,46 & $1,566 \mathrm{E}-04$ & 575 \\
\hline CP-S-028 & 8040 & $45,08 \%$ & 3,46 & $1,569 \mathrm{E}-04$ & 470 \\
\hline CP-S-032 & 7140 & $40,02 \%$ & 3,08 & $1,393 \mathrm{E}-04$ & 733 \\
\hline CP-S-034 & 7140 & $40,23 \%$ & 3,09 & $1,400 \mathrm{E}-04$ & 714 \\
\hline CP-S-036 & 5360 & $30,08 \%$ & 2,31 & $1,047 \mathrm{E}-04$ & 2418 \\
\hline CP-S-039 & 5360 & $30,05 \%$ & 2,31 & $1,046 \mathrm{E}-04$ & 3206 \\
\hline CP-S-038 & 3570 & $20,03 \%$ & 1,54 & $6,972 \mathrm{E}-05$ & 17038 \\
\hline CP-S-031 & 3570 & $20,03 \%$ & 1,54 & $6,972 \mathrm{E}-05$ & 18202 \\
\hline \multirow{2}{*}{\multicolumn{3}{|c|}{ Modelos de Fadiga }} & \multicolumn{3}{|c|}{$\mathrm{N}=116237(1 / \Delta \sigma)^{4,4286}$} \\
\hline & & & \multicolumn{3}{|c|}{$\mathrm{N}=7,0 \times 10^{-15}(1 / \varepsilon \mathrm{i})^{4,4286}$} \\
\hline
\end{tabular}

As Figuras 5.57 e 5.58 apresentam as curvas de fadiga das misturas, sem e com envelhecimento, do AMP PG 76 -22 em função da diferença de tensões e da deformação resiliente.

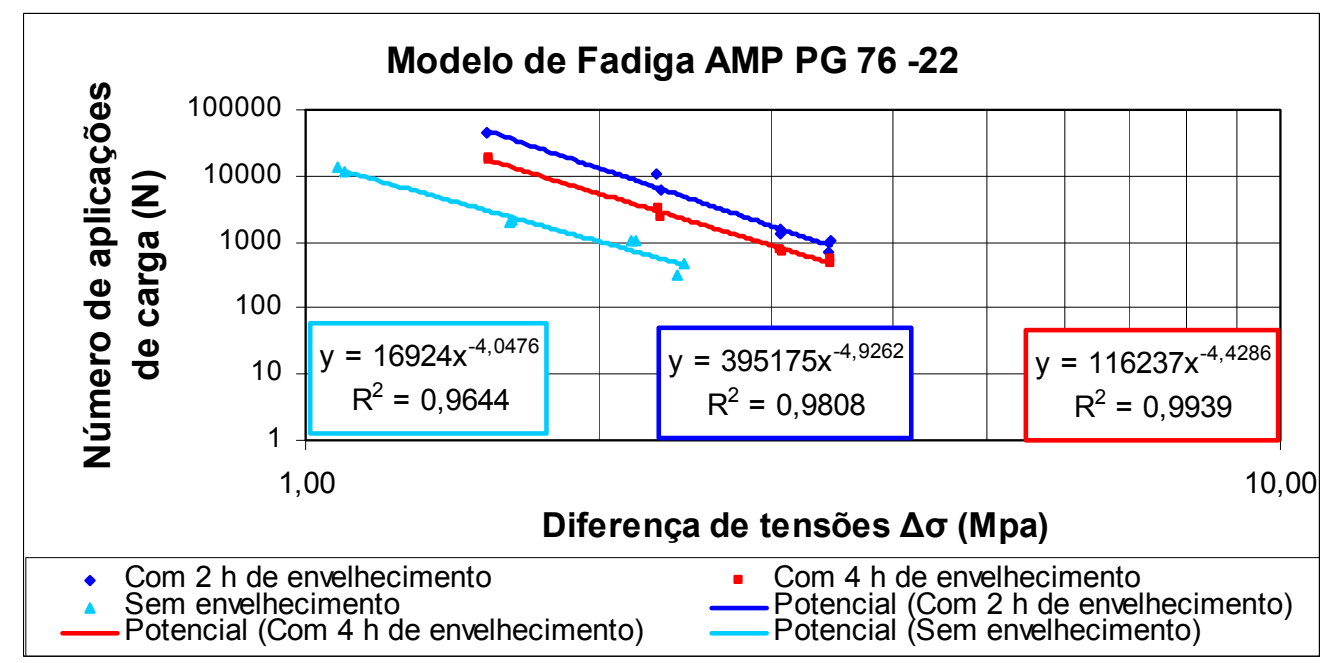

Figura 5.57 - Curvas de Fadiga em função da diferença de tensões para AMP PG 76 -22. 


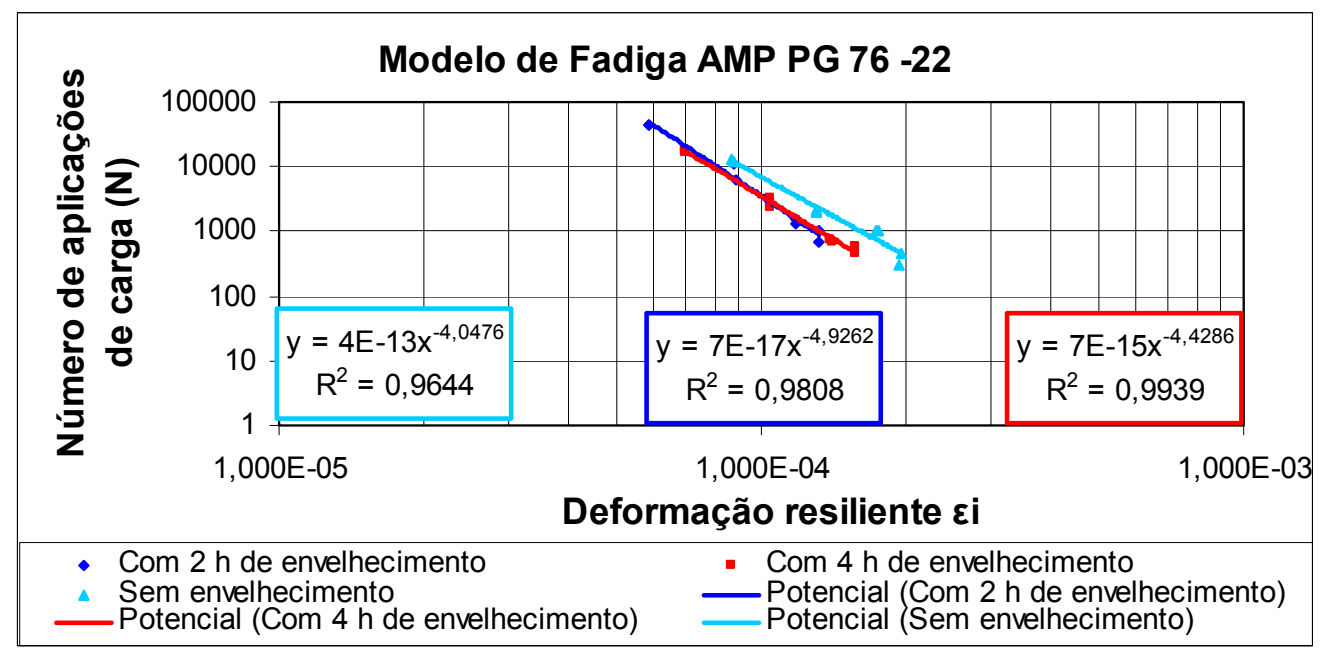

Figura 5.58 - Curvas de Fadiga em função da deformação resiliente para AMP PG 76 -22.

A Figura 5.57 mostra que para o mesmo valor de diferença de tensões as misturas com 2 horas de envelhecimento apresentam maiores valores de N. Porém, a Figura 5.58 mostra que para uma mesma deformação resiliente as misturas sem envelhecimento apresentam os maiores valores de $\mathrm{N}$.

Os parâmetros resultantes dos ensaios de fadiga são apresentados, resumidamente, nas Tabelas 5.40, 5.41 e 5.42, onde os coeficientes k1, k2 e n1 representam os parâmetros de fadiga das expressões (5.1) e (5.2):

$$
\begin{aligned}
& N=k 1\left(\frac{1}{\Delta \sigma}\right)^{k 2} \\
& N=n 1\left(\frac{1}{\varepsilon_{i}}\right)^{k 2}
\end{aligned}
$$


Tabela 5.40 - Parâmetros dos modelos de vida de Fadiga das misturas asfálticas sem envelhecimento

\begin{tabular}{cccccccc}
\hline Ligante Asfáltico & RT & MR & MR/RT & k1 & k2 & n1 & R $^{2}$ \\
\hline CAP PEN 60/70 & 0,97 & 2135 & 2205 & 3490,8 & 4,2683 & $6,0 \times 10^{-14}$ & 0,9788 \\
AMP Tipo I 60/60 & 1,21 & 2335 & 1925 & 12779 & 4,6417 & $5,0 \times 10^{-15}$ & 0,9814 \\
AMP PG 76 -22 & 1,36 & 3119 & 2302 & 16924 & 4,0476 & $4,0 \times 10^{-13}$ & 0,9644 \\
\hline
\end{tabular}

Tabela 5.41 - Parâmetros dos modelos de vida de Fadiga das misturas asfálticas com 2 h de envelhecimento

\begin{tabular}{cccccccc}
\hline Ligante Asfáltico & RT & MR & MR/RT & k1 & k2 & n1 & $\mathbf{R}^{\mathbf{2}}$ \\
\hline CAP PEN 60/70 & 1,29 & 4423 & 3419 & 26600 & 4,1743 & $5,0 \times 10^{-14}$ & 0,9717 \\
AMP Tipo I 60/60 & 1,65 & 5106 & 3092 & 158831 & 5,2113 & $5,0 \times 10^{-18}$ & 0,9911 \\
AMP PG 76 -22 & 1,90 & 6525 & 3427 & 395175 & 4,9262 & $7,0 \times 10^{-17}$ & 0,9808 \\
\hline
\end{tabular}

Tabela 5.42 - Parâmetros dos modelos de vida de Fadiga das misturas asfálticas com 4 h de envelhecimento

\begin{tabular}{cccccccc}
\hline Ligante Asfáltico & RT & MR & MR/RT & k1 & k2 & $\mathbf{n 1}$ & $\mathbf{R}^{\mathbf{2}}$ \\
\hline CAP PEN 60/70 & 1,58 & 5750 & 3631 & 82292 & 4,8964 & $4,0 \times 10^{-17}$ & 0,9907 \\
AMP Tipo I 60/60 & 1,78 & 6189 & 3479 & 458010 & 5,9932 & $2,0 \times 10^{-21}$ & 0,9887 \\
AMP PG 76 -22 & 1,92 & 5521 & 2873 & 116237 & 4,4286 & $7,0 \times 10^{-15}$ & 0,9939 \\
\hline
\end{tabular}

Nas Figuras 5.59, 5.60 e 5.61 são apresentadas as curvas de fadiga em função da diferença de tensões dos três ligantes asfálticos sem envelhecimento e com envelhecimentos em curto prazo. 


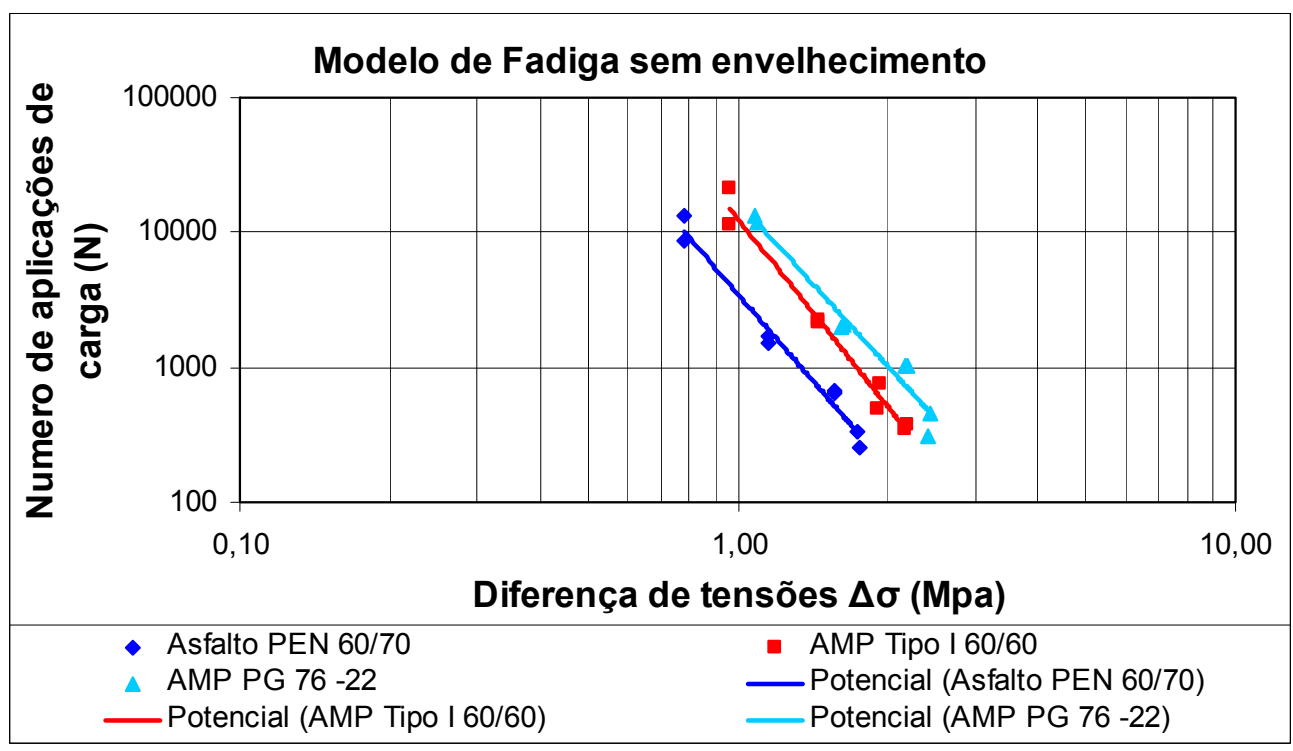

Figura 5.59 - Curvas de Fadiga sem envelhecimento em função da diferença de tensões.

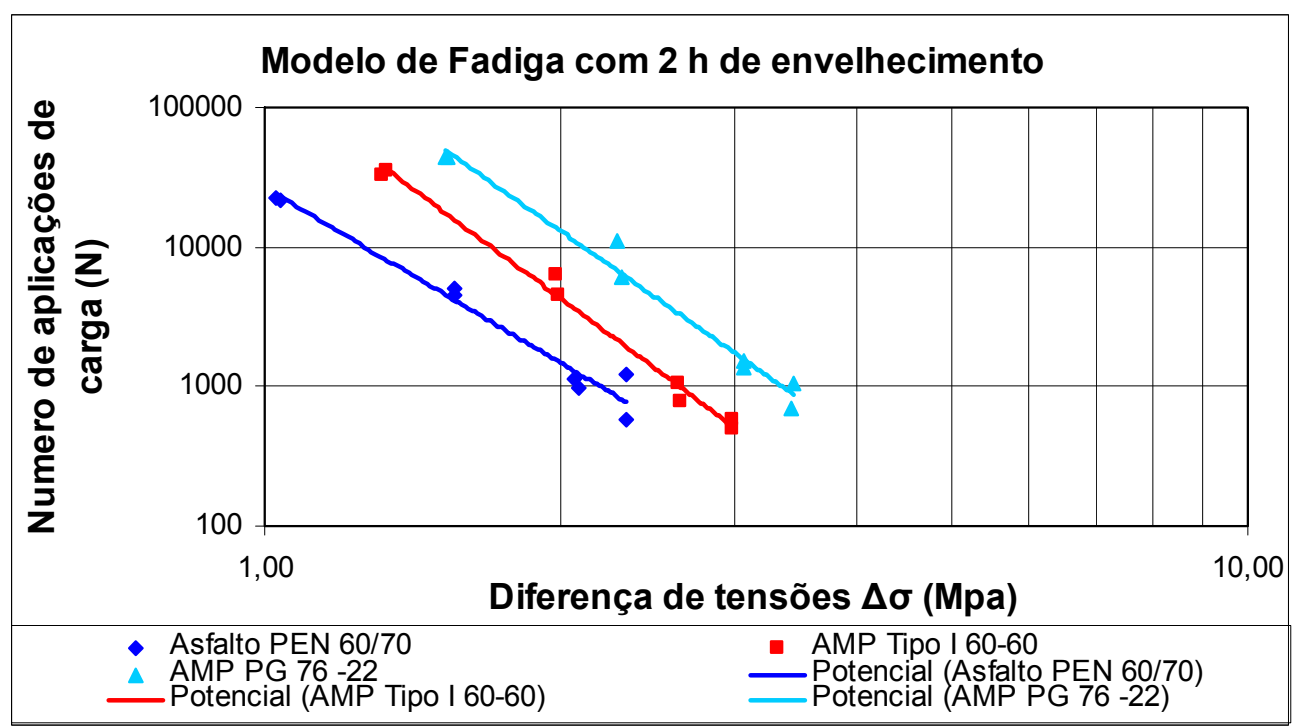

Figura 5.60 - Curvas de Fadiga com 2 h de envelhecimento em função da diferença de tensões. 


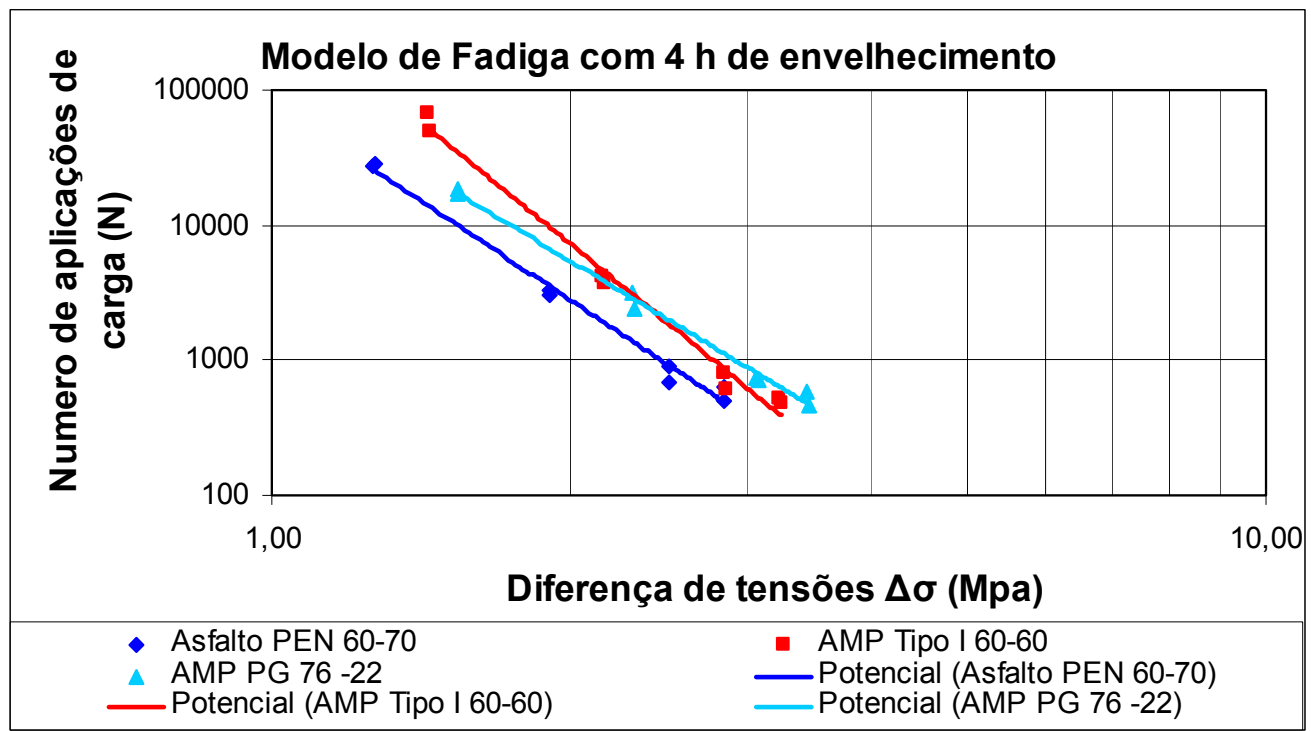

Figura 5.61 - Curvas de Fadiga com 4 h de envelhecimento em função da diferença de tensões.

Nas Figuras 5.62, 5.63 e 5.64 são apresentadas as curvas de fadiga em função da deformação resiliente dos três ligantes asfálticos, sem envelhecimento e com envelhecimentos em curto prazo.

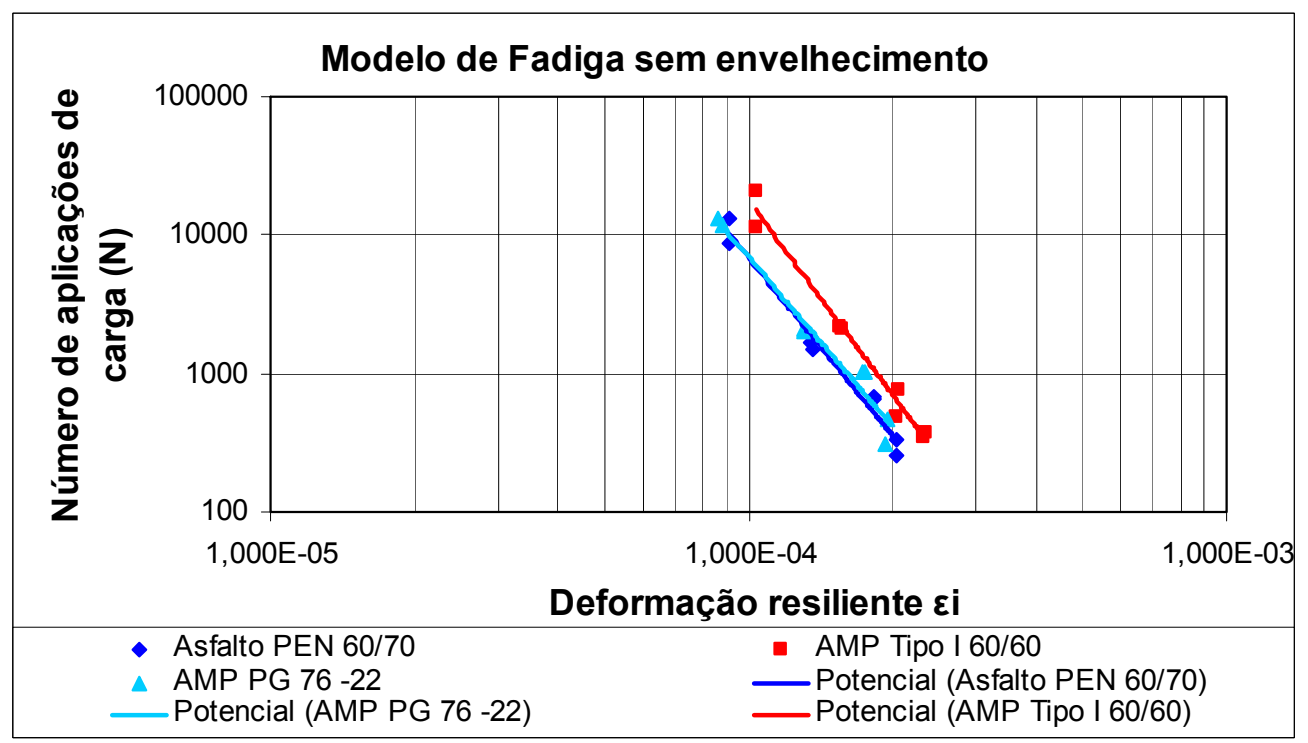

Figura 5.62 - Curvas de Fadiga sem envelhecimento em função da deformação resiliente. 


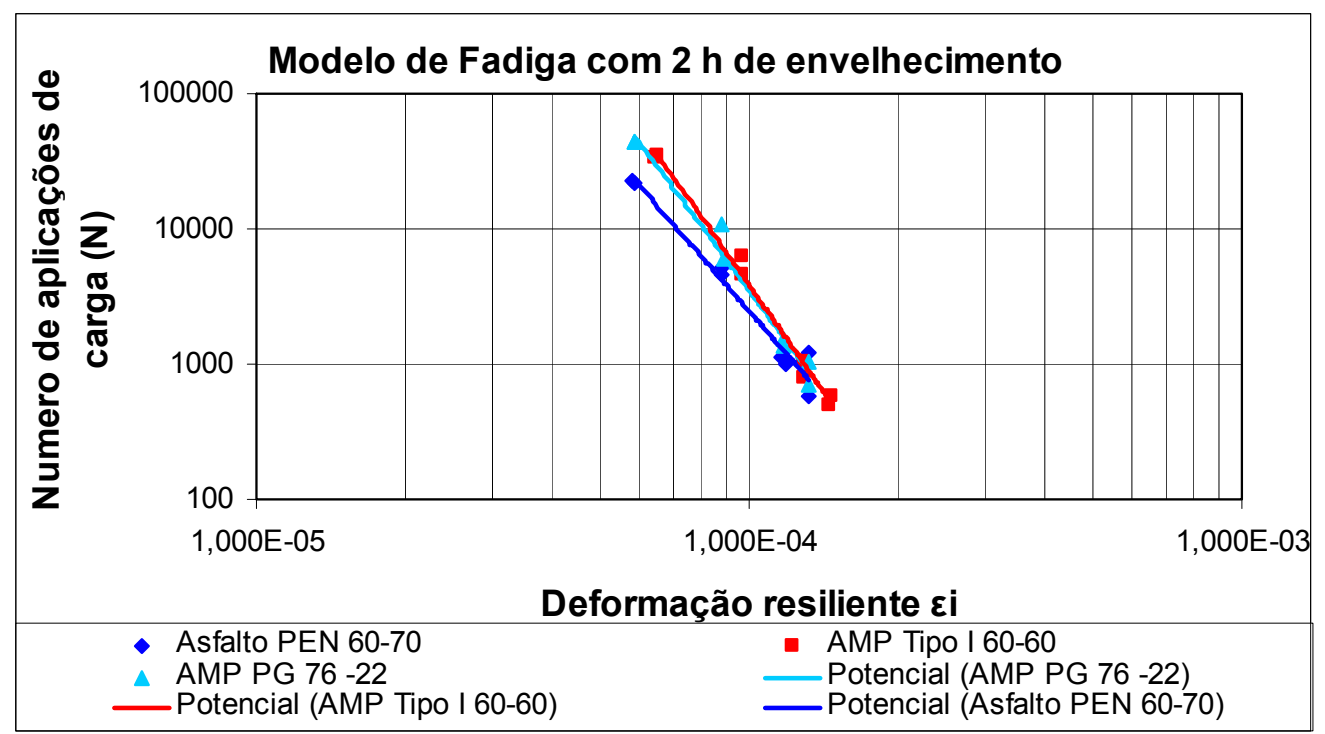

Figura 5.63 - Curvas de Fadiga com 2 h de envelhecimento em função da deformação resiliente.

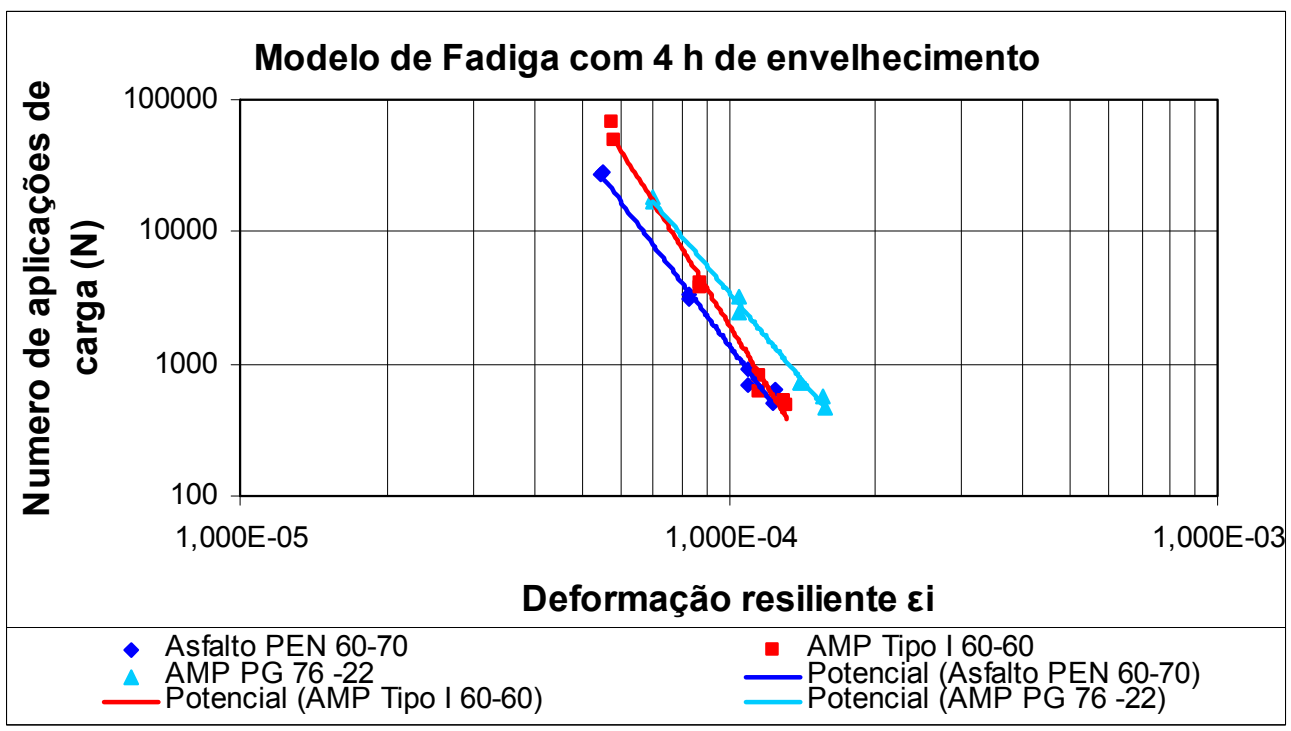

Figura 5.64 - Curvas de Fadiga com 4 h de envelhecimento em função da deformação resiliente. 


\subsubsection{Análise Mecanística da influência do tipo de ligante e do envelhecimento de curto prazo na vida de fadiga}

Foi realizada uma análise estrutural com o objetivo de comparar o comportamento das misturas com relação à vida de fadiga, com o auxílio do programa computacional ELSYM5 (Elastic Layered System 5), que determina as tensões, os deslocamentos e as deformações em uma estrutura de pavimento constituído por até cinco camadas elástico-lineares, sob uma condição de carregamento pré-estabelecida.

Para fins de comparação, faz-se necessário o estudo do comportamento das misturas a partir de um mesmo referencial, para o qual foram assumidas duas estruturas de pavimento muito utilizadas em vias de alto volume tráfego no Peru, como alguns trechos das rodovias Panamericana e Lima - La Oroya. A partir destes pavimentos (Figura 5.65) foram calculadas as tensões e deformações de tração nas fibras inferiores do revestimento.

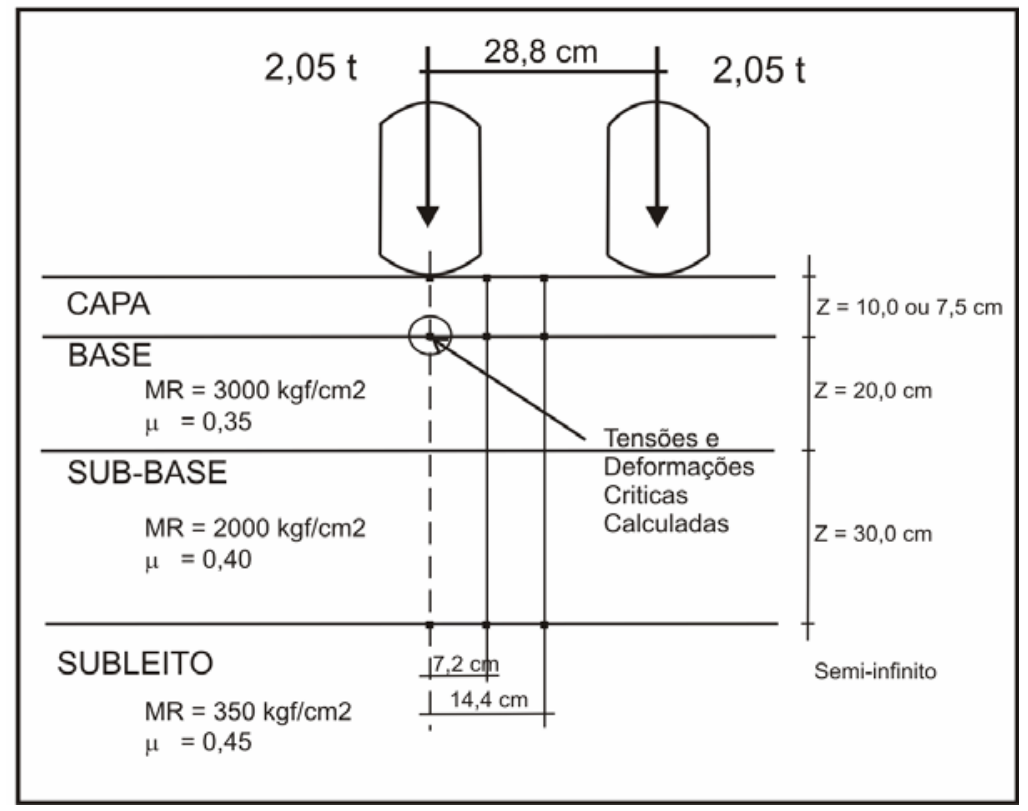

Figura 5.65 - Perfil utilizado, características e localização do ponto de tensões e deformações mais críticas. 
$\mathrm{Na}$ Tabela 5.43 apresentam-se os resultados das análises mecanísticas e o número de solicitações admissíveis ou vida de fadiga para os três ligantes asfálticos, em cada condição de envelhecimento, para uma estrutura de pavimento com uma espessura de capa de $10 \mathrm{~cm}$.

Tabela 5.43 - Vida de fadiga das misturas asfálticas para uma estrutura com capa de $10 \mathrm{~cm}$ de espessura, em cada condição de envelhecimento.

\begin{tabular}{ccccc}
\hline Condição & Modelo & $\begin{array}{c}\text { MR } \\
(\mathbf{k g f} / \mathbf{c m} 2)\end{array}$ & $\boldsymbol{\Delta \sigma}(\mathbf{M p a})$ & $\mathbf{N}$ \\
& \multicolumn{1}{c}{ Ligante Asfáltico: CAP PEN 60/70 } & & & \\
\hline Sem envelhecimento & $\mathrm{N}=3490,8(1 / \Delta \sigma)^{4,2683}$ & 21353 & 0,8383 & 7411 \\
Com 2 h. de envelhecimento & $\mathrm{N}=26600(1 / \Delta \sigma)^{4,1743}$ & 44229 & 1,2288 & 11255 \\
Com 4 h. de envelhecimento & $\mathrm{N}=82292(1 / \Delta \sigma)^{4,8964}$ & 57502 & 1,3991 & 15894 \\
\hline \multicolumn{6}{c}{ Ligante Asfáltico: AMP Tipo I 60/60 } & & \\
\hline Sem envelhecimento & $\mathrm{N}=12779(1 / \Delta \sigma)^{4,6417}$ & 23348 & 0,880 & 23131 \\
Com 2 h. de envelhecimento & $\mathrm{N}=158831(1 / \Delta \sigma)^{5,2113}$ & 51058 & 1,3204 & 37317 \\
Com 4 h. de envelhecimento & $\mathrm{N}=458010(1 / \Delta \sigma)^{5,9932}$ & 61893 & 1,4491 & 49588 \\
\hline \multicolumn{6}{c}{ Ligante Asfáltico: AMP PG 76 -22 } & & \\
\hline Sem envelhecimento & $\mathrm{N}=16924(1 / \Delta \sigma)^{4,0476}$ & 31194 & 1,0273 & 15176 \\
Com 2 h. de envelhecimento & $\mathrm{N}=395175(1 / \Delta \sigma)^{4,9262}$ & 65249 & 1,4856 & 56230 \\
Com 4 h. de envelhecimento & $\mathrm{N}=116237(1 / \Delta \sigma)^{4,4286}$ & 55213 & 1,3719 & 28655 \\
\hline
\end{tabular}

Para esta primeira estrutura de pavimento com capa de $10 \mathrm{~cm}$ de espessura, considerando a mesma estrutura proposta para todas as misturas asfálticas estudadas, pôde-se analisar comparativamente a influência do ligante asfáltico quanto à vida de fadiga estimada, para cada condição de envelhecimento.

Nas misturas sem envelhecimento, os AMP apresentaram vidas de fadiga de duas a três vezes maiores que o CAP PEN 60/70, sendo o AMP Tipo I 60/60 o que apresentou melhor resultado. 
Nas misturas com duas horas de envelhecimento, os AMP apresentaram vidas de fadiga de três a cinco vezes maiores que o CAP PEN 60/70, sendo das misturas com AMP PG 76 -22 os melhores resultados.

Para as misturas com 4 horas de envelhecimento, também os AMP apresentaram vidas de fadiga superiores, mostrando-se assim que os AMP têm melhor comportamento que o CAP convencional, fornecendo maiores vidas de fadiga para as três condições estudadas, como pode ser observado na Figura 5.66.

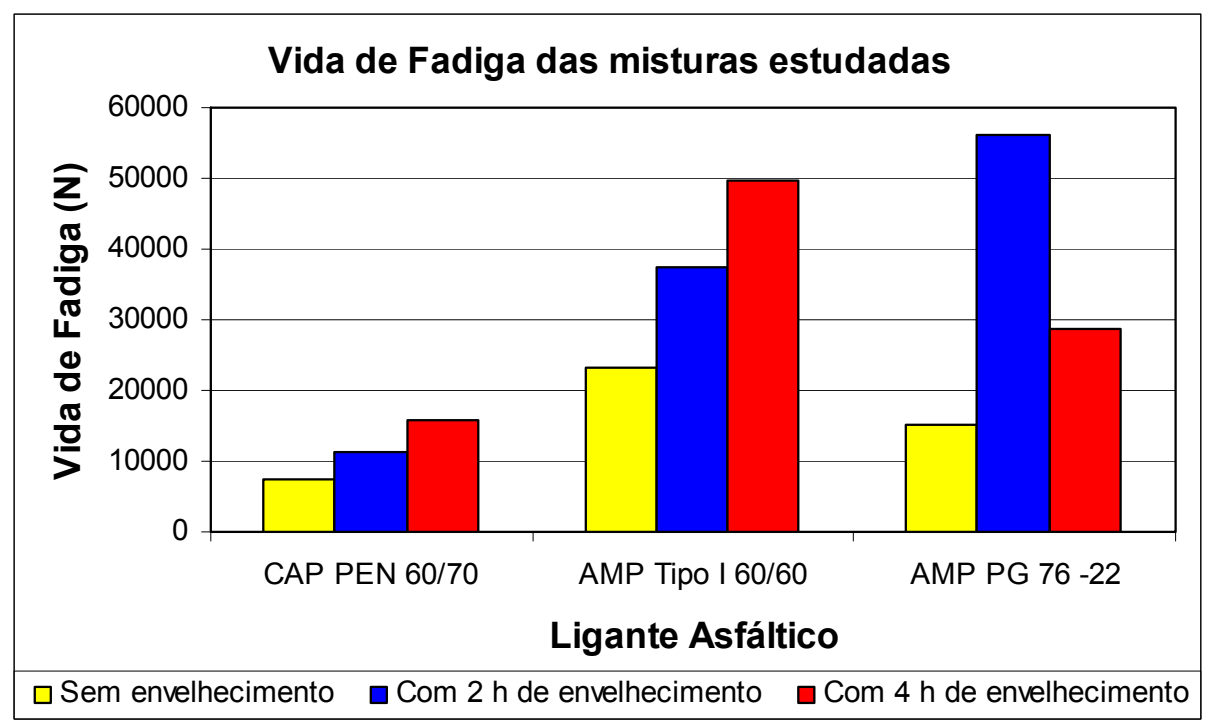

Figura 5.66 - Vida de Fadiga das misturas asfálticas estudadas para uma estrutura com capa de $10 \mathrm{~cm}$ de espessura, para cada condição de envelhecimento.

Na Tabela 5.44 apresentam-se os resultados das análises mecanísticas e o número de solicitações admissíveis ou vida de fadiga para os três ligantes asfálticos, em cada condição de envelhecimento, para uma estrutura de pavimento com uma espessura de capa de 7,5 cm. 
Tabela 5.44 - Vida de fadiga das misturas asfálticas par uma estrutura com capa de 7,5 cm de espessura, em cada condição de envelhecimento

\begin{tabular}{ccccc}
\hline Condição & Modelo & $\begin{array}{c}\text { MR } \\
(\mathbf{k g f} / \mathbf{c m} 2)\end{array}$ & $\boldsymbol{\Delta \sigma}(\mathbf{M p a})$ & $\mathbf{N}$ \\
& Ligante Asfáltico: CAP PEN 60/70 & & & \\
\hline Sem envelhecimento & $\mathrm{N}=3490,8(1 / \Delta \sigma)^{4,2683}$ & 21353 & 0,9484 & 4377 \\
Com 2 h. de envelhecimento & $\mathrm{N}=26600(1 / \Delta \sigma)^{4,1743}$ & 44229 & 1,4527 & 5596 \\
Com 4 h. de envelhecimento & $\mathrm{N}=82292(1 / \Delta \sigma)^{4,8964}$ & 57502 & 1,6782 & 6523 \\
\hline \multicolumn{6}{c}{ Ligante Asfáltico: AMP Tipo I 60/60 } & & \\
\hline Sem envelhecimento & $\mathrm{N}=12779(1 / \Delta \sigma)^{4,6417}$ & 23348 & 1,0010 & 12720 \\
Com 2 h. de envelhecimento & $\mathrm{N}=158831(1 / \Delta \sigma)^{5,2113}$ & 51058 & 1,5733 & 14972 \\
Com 4 h. de envelhecimento & $\mathrm{N}=458010(1 / \Delta \sigma)^{5,9932}$ & 61893 & 1,7461 & 16222 \\
\hline \multicolumn{6}{c}{ Ligante Asfáltico: AMP PG 76 -22 } & & \\
\hline Sem envelhecimento & $\mathrm{N}=16924(1 / \Delta \sigma)^{4,0476}$ & 31194 & 1,1892 & 8393 \\
Com 2 h. de envelhecimento & $\mathrm{N}=395175(1 / \Delta \sigma)^{4,9262}$ & 65249 & 1,7958 & 22093 \\
Com 4 h. de envelhecimento & $\mathrm{N}=116237(1 / \Delta \sigma)^{4,4286}$ & 55213 & 1,6416 & 12942 \\
\hline
\end{tabular}

Para esta segunda estrutura de pavimento com capa de 7,5 cm de espessura, considerando a mesma estrutura proposta para todas as misturas asfálticas estudadas, se observa que as vidas de fadiga de todos os ligantes asfálticos e para todas as condições de envelhecimento caíram quase pela metade, por efeito da diminuição da espessura da capa. Porém, manteve-se a mesma relação de vida de fadiga para todas as condições de envelhecimento, mostrando claramente que os AMP têm melhor comportamento que o CAP convencional, fornecendo maiores vidas de fadiga para as três condições estudadas, como pode ser observado na Figura 5.67 . 


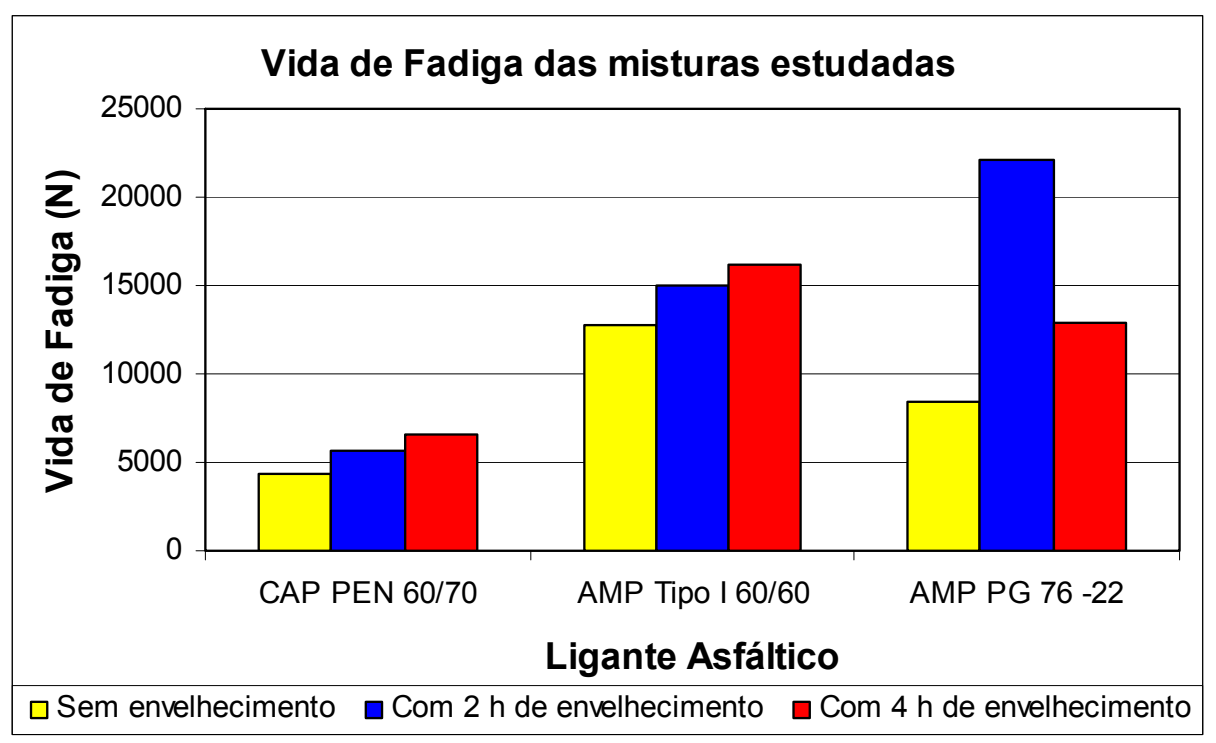

Figura 5.67- Vida de Fadiga das misturas asfálticas estudadas para uma estrutura com capa de $7,5 \mathrm{~cm}$ de espessura, para cada condição de envelhecimento

\subsection{CONSIDERAÇÕES FINAIS}

$\mathrm{Na}$ análise de resultados realizada em ligantes asfálticos observa-se que os ligantes asfálticos modificados por polímeros apresentam melhor comportamento que o ligante asfáltico convencional, apresentando maior grau de desempenho, menor suceptibilidade térmica e maior resistência ao envelhecimento. Da mesma forma a análise de resultados realizada em misturas asfálticas mostrou que os asfaltos modificados por polímeros apresentam melhor comportamento que o ligante asfáltico convencional para todas as condições de envelhecimento utilizadas nesta pesquisa. 
A coisa mais indispensável a um homem é reconhecer o uso que deve fazer do seu próprio conhecimento

(Platão) 


\section{CAPÍTULO VI}

\section{CONCLUSÕES E RECOMENDAÇÕES}

\subsection{CONSIDERAÇÕES INICIAIS}

No presente capítulo são apresentadas as conclusões do trabalho, baseadas na análise dos resultados obtidos em laboratório. São apresentadas, ainda, recomendações para trabalhos futuros, visando complementar e ampliar o alcance dos objetivos atingidos neste trabalho.

\subsection{CONCLUSÕES}

Sendo os objetivos deste trabalho avaliar o comportamento de misturas asfálticas peruanas produzidas com CAP PEN 60/70 e AMP Tipo I 60/60, estabelecer a distribuição de grau de desempenho de ligantes asfálticos para as diferentes regiões do Peru e avaliar o comportamento de AMP produzido para o grau de desempenho PG mais crítico do estado peruano, conclui-se, com base nos resultados apresentados:

\subsubsection{Quanto ao estudo e distribuição do grau de desempenho de ligantes asfálticos do Peru}

- Foi estabelecido o mapa de distribuição do PG do ligante asfáltico para as diferentes regiões do Peru o mesmo que deve ser constantemente atualizado com as bases de dados 
de todas as estações meteorológicas o que permitira selecionar o ligante asfáltico mais adequado para cada região de trabalho;

- Da distribuição do PG para as diferentes regiões do Peru se concluiu que a Região da Serra necessita de um ligante asfáltico com PG 58 -22 e para as regiões da Costa e Selva, de um ligante asfáltico com PG 70 -10, lembrando que não são considerados a velocidade e o volume de tráfego;

\subsubsection{Quanto aos resultados dos ensaios nos ligantes asfálticos}

- Os ligantes asfálticos modificados por polímeros apresentaram melhor comportamento que o ligante asfáltico convencional, apresentando baixo índice de susceptibilidade térmica, maior grau de desempenho PG e maior resistência ao envelhecimento;

- Todos os ligantes asfálticos avaliados, para todas as condições de envelhecimento, apresentaram excelente resistência ao dano causado pela umidade induzida;

\subsubsection{Quanto aos resultados dos ensaios nas misturas asfálticas}

- Os teores de projeto encontrados para os três asfaltos utilizados foram bem parecidos, fenômeno que se atribui à utilização das faixas de viscosidade de usinagem e compactação recomendadas pelo fabricante do AMP;

- Os menores valores de fluência e os maiores valores de estabilidade Marshall, nos teores de projeto, ocorreram para as misturas com AMP, fato atribuído à maior viscosidade dos AMP;

- O controle rigoroso da granulometria, utilizando todas as peneiras especificadas pelo Superpave, resultou em grande repetibilidade, tanto na determinação das características 
volumétricas dos corpos de prova, como nos resultados dos ensaios mecânicos, para todas as condições de envelhecimento;

- A resistência à tração das misturas com AMP mostrou-se bem superior à do CAP convencional PEN 60/70, para todas as condições de envelhecimento e nas duas temperaturas de ensaio realizadas, apresentando, também, a mesma taxa de variação nas duas temperaturas de ensaio e uma boa repetibilidade;

- O módulo de resiliência apresentou um comportamento similar à resistência à tração. As misturas com AMP apresentaram os maiores valores de módulo de resiliência, em todas as condições de envelhecimento, apresentando a mesma taxa de variação nas duas temperaturas de ensaio, obtendo-se maiores incrementos na variação do MR que na RT com a variação de temperatura de $25^{\circ} \mathrm{C}$ para $5{ }^{\circ} \mathrm{C}$;

- Os resultados do ensaio de fluência por compressão uniaxial estática, mostraram que os asfaltos modificados por polímeros apresentaram as maiores taxas de recuperação elástica, mesmo sendo as deformações totais obtidas similares, apresentando também os maiores módulos de fluência a $4500 \mathrm{~s}$ e as mais baixas inclinações das curvas de fluência, confirmando o melhor desempenho dos asfaltos modificados por polímeros;

- Os resultados do ensaio de fluência por compressão uniaxial dinâmica mostraram, claramente, a melhor resistência à deformação permanente dos asfaltos modificados por polímeros, apresentando menores porcentagens de deformação total, menores inclinações da curva de fluência e maiores módulos de fluência que o asfalto convencional PEN 60/70;

\subsubsection{Quanto aos resultados da análise mecanística}

- Os resultados da análise mecanística mostraram que os asfaltos modificados por polímeros apresentaram vidas de fadiga maiores que o CAP PEN 60/70, para todas as 
condições de envelhecimento, variáveis entre $200 \%$ a 500\% em função da condição de envelhecimento, sendo que os maiores valores de vida de fadiga foram observados para misturas com duas horas de envelhecimento. Deve-se ressaltar que o objetivo desta pesquisa foi comparar o desempenho das misturas asfálticas à luz de resultados de ensaios de laboratório, ou seja, os modelos apresentados não devem ser utilizados para a previsão da vida de fadiga das misturas em serviço, devido à falta de ajuste laboratório/campo;

\subsubsection{Considerações gerais}

- De modo geral, nos ensaios Marshall, resistência à tração, resistência à tração após umidade induzida, módulo de resiliência, fluência por compressão uniaxial estática, fluência por compressão uniaxial dinâmica, vida de fadiga e pela análise estrutural com o programa computacional Elsym5, as misturas com asfalto modificado por polímero (Tipo I 60/60 e PG 76 -22) apresentaram melhor desempenho que o asfalto convencional (PEN 60/70).

\subsection{RECOMENDAÇÕES PARA PESQUISAS FUTURAS}

Com base nos resultados obtidos e nas análises efetuadas neste trabalho, são sugeridas pesquisas complementares, visando:

- Estabelecer modelos de previsão para o cálculo de baixas e altas temperaturas do pavimento a partir de estudo de pavimentos em serviço nas regiões peruanas, levando 
em consideração os fatores próprios desta região, como a incidência dos raios ultravioleta (UV), Latitude e Altitude;

- Desenvolver ligantes asfálticos modificados por polímero a partir de ligantes asfálticos peruanos PEN 60/70 e PEN 85/100, para uso nas regiões da costa, serra e selva peruana com as características de trabalhabilidade e desempenho mais adequados para cada região, visando obter a melhor relação custo/beneficio, também considerando o efeito do envelhecimento destes ligantes asfálticos modificados nas condições especificadas pelo método Superpave (RTFOT e PAV);

- Estudar o efeito da taxa de cisalhamento sobre a viscosidade nas temperaturas de usinagem e de compactação de misturas asfálticas empregando os ligantes asfálticos estudados nesta pesquisa e outros comumente empregados no Peru e validar o método de Katri et al. (2001) para determinação de temperaturas de usinagem e de compactação de ligantes asfálticos pseudoplásticos para os materiais estudados nesta pesquisa e outros empregados no Peru;

- Estudar o efeito do envelhecimento a longo prazo em misturas asfálticas soltas em estufa e do envelhecimento provocado pela exposição de corpos-de-prova compactados à radiação ultravioleta em temperaturas de serviço, utilizando os ligantes asfálticos estudados nesta pesquisa e outros comumente empregados no Peru;

- Avaliar o comportamento das misturas asfálticas utilizadas nesta pesquisa à deformação permanente em simulador de tráfego, que fornece melhores resultados em relação aos ensaios de fluência por compressão uniaxial estática e dinâmica e verificar a validade de parâmetros limites de aceitação em função do tipo e volume de tráfego. 
O Homem prudente não diz tudo quanto pensa, mas pensa tudo quanto diz (Aristóteles) 


\section{REFERÊNCIAS BIBLIOGRAFICAS}

AASHTO T-19/T 19M (2000). Standard Method of Test for Bulk Density (Unit Weight) and Voids in Aggregate.

AASHTO T 96. Standard Method of Test for Resistance to Degradation of Small-Size Coarse Aggregate by Abrasion and Impact in the Los Angeles Machine.

AASHTO T 104. Standard Method of Test for Soundness of Aggregate by use of Sodium Sulfate or Magnesium Sulfate.

AASHTO T 112. Standard Method of Test for Clay Lumps and Friable Particles in Aggregate.

AASHTO T 315/02. (2002) Standard Method of Test for Determining the Rheological Properties of Asphal Binder Using a Dynamic Shear Rheometer (DSR).

AASHTO MP 1/01. (2001) Standard Specification for Performance Graded Asphalt Binder.

AASHTO MP 2/01. (2001) Standard Specification for Superpave Volumetric Mix Desing.

AASHTO PP-2. Standard Practice for Mixture Conditioning of Hot Mix Asphalt (HMA).

AASHTO TP 31/94. (1994) Standard Method of Test for Determination of the Resilient Modulus of Bituminous Mixtures by Indirect Tension.

AASHTO T 283. Standard Method of Test for Resistance of Compacted Asphalt Mixtures to Moisture-Induced Damage.

AASHTO T 176. Standard Method of Test for Plastic Fines in Graded Aggregates and Soils by Use of the Sand Equivalent Test. 
ABNT NBR 6560/00. (2000) Materiais betuminosos - Determinação do ponto de amolecimento - Método do anel e bola, Associação Brasileira de Normas Técnicas Método de Ensaio, Brasília / DF, Brasil, 4. p.

ABNT NBR 15235/06. (2006) Materiais asfálticos - Determinação do efeito do calor e do ar em uma película delgada rotacional, Associação Brasileira de Normas Técnicas Método de Ensaio, Brasília / DF, Brasil, 8. p.

ABNT NBR 15184 /03. (2003) Materiais betuminosos - Determinação da viscosidade em temperatuaras elevadas usando um viscosímetro rotacional, Associação Brasileira de Normas Técnicas - Método de Ensaio, Brasília / DF, Brasil, 4. p.

ABNT NBR 14736 /01. (2001) Materiais betuminosos - Determinação da viscosidade em temperatuaras elevadas usando um viscosímetro rotacional, Associação Brasileira de Normas Técnicas - Método de Ensaio, Brasília / DF, Brasil, 4. p.

ASTM C127-04. (2004) Standard Test Method for Density, Relative Density (Specific Gravity), and Absorption of Coarse Aggregate.

ASTM C128-04. (2004) Standard Test Method for Density, Relative Density (Specific Gravity), and Absorption of Fine Aggregate.

ASTM C117-04. (2004) Standard Test Method for Materials Finer than $75 \mu \mathrm{m}$ $\left(N^{\circ} 200\right)$ Sieve in Mineral Aggregates by Washing.

ASTM C136-06. (2006) Standard Test Method for Sieve Analysis of Fine and Coarse Aggregate.

ASTM D5-97. (1997) Standard Test Method for Penetration of Bituminous Materials.

ASTM D36-95. (1995) Standard Test Method for Softening Point of Bitumen (Ring and Ball Apparatus). 
ASTM D4402-02. (2002) Standard Test Method for Viscosity Determination of Asphalt at Elevated Temperatures Using a Rotational Viscometer.

ASTM D92-05. (2005) Standard Test Method for Flash and Fire Points by Cleveland Open Cup Tester.

ASTM D2872-02. (2002) Standard Test Method for Effect of Heat and Air on a Moving Film of Asphalt (Rolling Thin-Film Oven Test).

ASTM D454-04. (2004) Standard Test Method for Rubber Deterioration by Heat and Air Pressure.

ASTM D6648-01. (2001) Standard Test Method for Determining the Flexural Creep Stiffness of Asphalt Binder Using the Bending Beam Rheometer (BBR).

ASTM D6926-04. (2004) Standard Practice for Preparation of bituminous Specimens Using Marshall Apparatus.

ASTM D2041-00. (2000) Standard Method for Theoretical Maximum Specific Gravity and Density of Bituminous Paving Mixtures.

ASTM D6926-04. (2004) Standard Practice for Preparation of Bituminuos Specimens Using Marshall Apparatus.

ASTM D2493-04. (2004) Standard Viscosity-Temperature Chart for Asphalt.

ASTM D6927-05. (2005) Standard Test Method for Marshall Stability and Flow of Bituminous Mixtures.

ASTM D4123-82. (1982) Standard Test Method for Indirect Tension Test For Resilient Modulus Of Bituminous Mixtures. 
ANANI, B.A.; BALGHUNAIM, F.A.; AL-HAZZAA, A.S. (1990) Laboratory and fieldstudy of pavement rutting in Saudi Arabia. Transportation Research Record. N. 1259, p. 7990.

BAHIA H.U., PERDOMO D., TURNER P. (1997) Applicability of Superpave binder testing protocols to modified binders. Transportation Research Record 1997;1586:16-23.

BAHIA, H. U.; ZHAI, H.; ZENG, M.; HU, Y.; TURNER, P. (2001) Development of binder specification parameters based on characterization of damage behavior. Association of Asphalt Paving Technologists, v. 70, p. $442-470$.

BARKSDALE, R. D., ALBA, J., KHOSLA, N. P., KIM, R. e RAHMAN, M.S. (1997) Laboratory Determination of Resilient Modulus for Flexible Pavement Design. In: Project 1-28, Final Report, Georgia Tech Project E20-634, USA.

BECKER Y., MÉNDEZ M.P., RODRÍGUEZ Y. (2001) Polymer modified asphalt. Vision Technologic 2001:39-50.

BERTOLLO M. S. A. (2002) Avaliação laboratorial de misturas asfálticas densas modificadas com borracha reciclada de pneus. 198p. Tese de DSc. EESC-USP, São Carlos, SP, Brasil.

BINDER EXPERT TASK GROUP WHITE PAPER. (2001) PG grade selection adjusting $T_{(\text {high) }}$ for traffic. 
BOULDIN, M.G.; COLLINS, J.H. (1990) Rheology and microstructure of polymer/asphalt blends. SHELL Dev. Co. - Rubber Chemistry and Technology 64, pags 577-600.

BOSSCHER P. (2000) Relationship between pavement temperature and weather data. Transportation Research Board, Washington, D.C. Proceedings TRB Annual Meeting.

BRÛLÉ, B. (1996) Polymer-modified asphalt cements used in the road construction industry. basic principles. Transportation Research Record 1535, p. 48-53.

BROWN E. R., KANDHAL S. P., ZHANG J. (2001) Performance Testing for Hot Mix Asphalt. NCAT Report 01-05, November 2001, Auburn University, Alabama.

BROWN, E. R., COOLEY JR, L. A. (1999) Designing Stone Matrix Asphalt Mixtures for Rut-Resistant Pavements. Part 1: Summary of Research Results, Part 2: Mixture Design Method, Construction Guidelines, and Quality Control/Quality Assurance Procedures. NCHRP Report 425. National Cooperative Highway Research Program, Transportation Research Board, National Research Council, Washington, D.C., EUA.

CARPENTER, S. H.; VANDAM, T. (1987) Laboratory performance comparisons of polymer-modified and unmodified asphalt concrete mixtures. Transportation Research Record 1115. p. 62-74.

CERATTI, J. A.; RUWER, P. M.; OLIVEIRA, J. A. (1996) Estudo do comportamento mecânico de concreto asfáltico com ligante modificado com polímero. $13^{\circ}$ Encontro de Asfalto, v.1, p. 290-303. 
COELHO, V. (1996) Contribuição ao estudo das deformações permanentes, nas condições do Brasil, em camadas de concreto asfálticos de pavimentação. São Carlos, 281p. Tese DSc. EESC-USP, São Carlos, SP, Brasil.

C-SHRP. (1999) Improved standards for a new millennium, C-SHRP Technical Brief \# 17.

DER-SP-M 148/60. (1960) Dosagem de misturas betuminosas pelo método da superfície específica Departamento de Estradas de Rodagem do estado de São paulo, São Paulo, SP, Brasil, 7. p.

DE SENÇO, Wlastermiller. (1997) Manual de técnicas de pavimentação. Editora PINI ltda $746 \mathrm{p}$.

DNER-EM 367/97. (1997) Material de Enchimento para Misturas Betuminosas, Departamento Nacional de Estradas de Rodagem - Especificação de Material, Rio de Janeiro, RJ, Brasil, 3. p.

DNER-ES 313/97. (1997) Pavimentação - Concreto Betuminoso. Departamento Nacional de Estradas de Rodagem - Especificação de Serviço, Rio de Janeiro, RJ, Brasil, 16 p.

DNER ME 035/98. (1998) Agregados - Determinação da abração “Los angeles". Departamento Nacional de Estradas de Rodagem - Método de Ensaio, Rio de Janeiro, RJ, Brasil, 6. p. 
DNER ME 086/94. (1994) Agregados - Determinação do índice de forma. Departamento Nacional de Estradas de Rodagem - Método de Ensaio, Rio de Janeiro, RJ, Brasil, 5. p

DNER ME 089/94. (1994) Agregados - Avaliação da durabilidade pelo emprego de soluções de sulfato de sódio ou de magnésio. Departamento Nacional de Estradas de Rodagem - Método de Ensaio, Rio de Janeiro, RJ, Brasil, 6. p.

DNER ME 054/97. (1997) Equivalente de Areia. Departamento Nacional de Estradas de Rodagem - Método de Ensaio, Rio de Janeiro, RJ, Brasil, 10. p.

DNER ME 083/98. (1998) Agregados - Análise Granulométrica, Departamento Nacional de Estradas de Rodagem - Método de Ensaio, Rio de Janeiro, RJ, Brasil, 05. p.

DNER ME 003/99. (1999) Material Betuminoso - Determinação da Penetração, Departamento Nacional de Estradas de Rodagem - Método de Ensaio, Rio de Janeiro, RJ, Brasil, 07. p.

DNER ME 148/94. (1999) Material Betuminoso - Determinação dos pontos de Fulgor e de Combustão, Departamento Nacional de Estradas de Rodagem - Método de Ensaio, Rio de Janeiro, RJ, Brasil, 02. p.

DNER-ES 385/99. (1999) Pavimentação - Concreto Asfáltico com asfalto polímero, Departamento Nacional de Estradas de Rodagem - Especificação de Serviço, Rio de Janeiro, RJ, Brasil, 15. p. 
DNER ME 043/95. (1995) Misturas betuminosas a quente - Ensaio Marshall, Departamento Nacional de Estradas de Rodagem - Método de Ensaio, Rio de Janeiro, RJ, Brasil, 11. p.

DNER ME 138/94. (1994) Misturas betuminosas - Determinação da resistência à tração por compressão diametral, Departamento Nacional de Estradas de Rodagem - Método de Ensaio, Rio de Janeiro, RJ, Brasil, 4. p.

DNER ME 133/94. (1994) Misturas betuminosas - Determinação do módulo de resiliência, Departamento Nacional de Estradas de Rodagem - Método de Ensaio, Rio de Janeiro, RJ, Brasil, 5. p.

DNER EM 396/99. (1999) Cimento Asfáltico Modificado por Polímero, Departamento Nacional de Estradas de Rodagem - Especificação de Material, Rio de Janeiro, RJ, Brasil, 4. p.

DNER ME 043/95. (1995) Misturas betuminosas a Quente - Ensaio Marshall, Departamento Nacional de Estradas de Rodagem - Método de Ensaio, Rio de Janeiro, RJ, Brasil, 11. p.

FURLAN A.P., GOUVEIA L.T., FABBRI G.T.P., FERNANDES JR J.L. (2004) Influência de características dos agregados na susceptibilidade a dano por umidade de misturas asfálticas - $17^{\circ}$ Encontro de Asfalto do Instituto Brasileiro de Petróleo - 13 a 15 de dezembro de 2004. Rio de Janeiro. pp. 198 - 206. 
GONTIJO, P. R. A. (1980) A fadiga de misturas betuminosas. Condição essencial no desenvolvimento racional de pavimentos flexíveis. $15^{\mathrm{a}}$ Reunião Anual de Pavimentação. 55 p.

GOUVEIA, L.T., FURLAN, A.P., PARREIRA A.B., FERNANDES JR J.L., FABBRI G.T.P. (2003) Considerações acerca da absorção de asfalto pelos agregados e sua influência na susceptibilidade à umidade In: XVIII ANPET - Congresso de Pesquisa e Ensino em Transportes, Anais, vol 1. Rio de Janeiro. pp. 138 - 149.

GRECO, J.A.S. (2004) Avaliação da influência de alguns fatores nas propriedades mecânicas de misturas asfálticas densas, a luz da técnica de planejamento e análise de experimentos fatoriais fracionários assimétricos, 340p. Tese de DSc. EESC-USP, São Carlos, SP, Brasil.

HAND, A.J., STIADY, J.L., WHITE, T.D. et al. (2001) Gradation effects on hot-mix asphalt performance. In: Journal of the Transportation Research Board. National Academy Press. Asphalt Mixtures, 2001, no. 1767, pp 152-157.

HICKS G., FINN F., MONISMITH C., LEAHY R. (1993) Validation of SHRP binder specification through mix testing - Preprints of Asphalt Association of Paving Technologists vol 62 p 565 .

HIGHWAY RESEARCH BOARD. (1962) The AASHO Road Test. Washington, D. C., Higway Research Board, special Report 73, 117 p. 
IBP, Instituto Brasileiro de Petróleo. (1994) Informações básicas sobre materiais asfálticos. Comissão do asfalto, 68 p.

IBP, Instituto Brasileiro de Petróleo. (1996) Informativo "O asfalto". Rio de Janeiro, p 1 - 5. ISACSSON, U.; LU, X. (1995) Testing and appraisal of polymer modified road bitumens stated of art. Materials and Structures, v. 28, p. 139-159.

KANDHAL, P. S.; FOO, K. Y.; MALLICK, R. B. (1998) A critical review of VAM requirements in Superpave. National Center for Asphalt Technology. NCAT Report $N^{\circ}$ 98-1. Jan.

KANDHAL, P.S.; MALLICK, R.B. (2001) Effect of mix gradation on rutting potential of dense-graded asphalt mixtures. Transportation Research Record, n. 1767, p.146-151.

KANDHAL, P.S; COOLEY JR., L.A. (2001) The Restricted Zone in the Superpave Aggregate Gradation Specification. NCHRP Report 464 from National Cooperative Highway Research Program. National Academy Press, Washington D C.

KANDHAL, P.S.; COOLEY JR., L.A. (2002) Investigation of the Restricted Zone in the Superpave Aggregate Gradation Specification. Journal of the Association of Asphalt Paving Technologists, v. 71, p. 479-510.

KATRI, A.; BAHIA, H. U.; HANSON, D. (2001) Mixing and compaction temperatures for modified binders using the Superpave gyratory compactor. Association of Asphalt Paving Technologists, v. 70, p. 368 - 402. 
KIN, Y.R.; KIN, N.; KHOSLA, N.P. (1992) Effects of aggregate type and graduation on fatigue and permanent deformation of asphalt concrete. In: MEININGER, R.C. (ed.) Effects of aggregate and mineral fillers on asphalt mixture performance. American Society for Testing and Materials (ASTM), Philadefia, 1992.

LEAL, José C. M. (1999) Estudo Comparativo de Concreto Betuminoso Usinado à Quente Utilizando-se Agregado Calcário, CAP Puro e CAP Polimerizado. Disertação de MSc, UFPB, João Pessoa, PB, Brasil.

LEITE, L.F.M. (1999) Estudo de Preparo e Caracterização de Asfaltos Modificados por Polímeros, 267p. Tese de D.Sc., COPPE/UFRJ, Rio de Janeiro, RJ, Brasil.

LEITE, L.F.M.; SOARES, B.G. (1997) Boletim Técnico da PETROBRAS, Avaliação da compatibilidade e reologia de asfaltos modificados por SBS Rio de Janeiro, 40 (2/4) : 79-87, abr/dez 1997.

LEITE, L.F.M., BITTENCOURT, C.P. (2004) Caracterização reológica de cimentos asfalticos de petróleo e asfaltos modificados. II encontro Brasileiro de reologia, Julio 7 - 9 2004, Rio de Janeiro, RJ, Brasil.

LEITE, L.F.M., MOTTA, L.M.G., BERNUCCI, L.B. \& SOARES, J.B. (2000) Mechanical behavior of asphalt rubber mixes prepared in laboratory. In: Asphalt Rubber - The Pavement Material of the 21st Century - Proceedings. Vilamoura, Portugal. pp. 309318. 
LITTLE,D. N.; BUTTON, J. W.; YOUSSEF, H. (1993) Development of criteria to evaluate uniaxial creep data and asphalt concrete permanent deformation potential. Transportation Research Record 1417, p.49 - 57.

LU, X.; ISACSSON, U. (1997) Influence styrene - butadiene - styrene and polymer modification on bitumen viscosity. Fuel, V 76, N14/15, 1353-1359.

LTPP-FWHA. (1998) LTPP Data Analysis: Improved Low Pavement Temperature Prediction, U.S. Department of transportation Federal Highway Administration, June 1998, FHWA RD-97-104.

MANO, E.B. (1985) Introdução a polímeros, 111p Editora Edgard Blücher Ltda São Paulo SP, Brasil.

MARQUES, G.L.O. (2004) Utilização de modulo de resiliência como critério de dosagem de mistura asfáltica; efeito da compactação por impacto e giratoria, $461 \mathrm{p}$. Tese de D.Sc., COPPE/UFRJ, Rio de Janeiro, RJ, Brasil.

MARTINHO, F. G.; MONTENEGRO, F. G.; TRAJANO, L (1994) Coperflex Asphalt uma combinação e elastomero. Anais do 12 encontro de asfalto, v.2, p. $281-291$.

MC GENNIS R.B., ANDERSON T.M., KENNEDY T.W., SOLAIMANIAN, M. (1994) Background of Superpave asphalt mixture design and analysis - Report FHWA-SA-95003. 
MEDINA, J., (1997) Mecânica dos Pavimentos, 380p. COPPE/UFRJ, Editora UFRJ, Rio de Janeiro-RJ, Brasil.

MOHAMED, H. H.; YUE, Z. (1994) Criteria for evaluation of rutting potential based on repetitive uniaxial compression test. Transportaion Research Record 616, p. 38 - 40.

MOHSENI A. (1996) LTPP Seasonal AC pavement temperature models (SATP) - Federal Highway Administration FHWA, October 29.

MOHSENI, A. E CARPENTER S. (2004) Development of enhanced algorithm for Superpave High Temperature Performance Grade (PG) Selection and New Software Version - Long-Term Pavement Performance Group, Federal Highway Administration.

MONISMITH, C.L., DEACON, J.A., CRAUS, J. TANGELLA, S.C.S.R. (1990) Summary report on fatigue response of asphalt mixtures. Prepared for Strategic Highway Research Program, Project A-003-A. Institute of Transportation Studies, University of California, Berkeley, USA.

MOURÃO, FABRÍCIO A. L. (2003) Misturas Asfálticas de Alto Desempenho Tipo SMA, 131p. Dissertação de MSc. COPPE/UFRJ, Rio de Janeiro, RJ, Brasil.

MOTTA, L. M. G., TONIAL, I., LEITE, L. F., CONSTANTINO R. S. (1996) Princípios do Projeto e Análise Superpave de Misturas Asfálticas. Tradução comentada: Background of SUPERPAVE Asphalt Misture Design and Analysis, $n^{\circ}$ FHWA-SA-95003, Petrobrás, Rio de Janeiro, RJ, Brasil. 
MUGAYAR N. A. (2004) Avaliação dos efeitos do tipo de asfalto e da distribuição granulométrica do agregado nas fluências estática e dinâmica de misturas asfálticas densas, 118p. Dissertação de MSc. EESC-USP, São Carlos, SP, Brasil.

PINHEIRO, J.H.M., SOARES, J.B. \& LEITE, L.F.M. (2003) Caracterização de misturas asfálticas com borracha produzidas pelos processos úmido e seco. In: XVII ANPET - Congresso de Pesquisa e Ensino em Transportes, Anais, vol 1. Rio de Janeiro. pp. 116 $-129$.

PINTO, J. A. V. (1993) O que são asfaltos modificados por polímeros? In: Reunião anual de pavimentação urbana, 4a , Maceió-AL, Associação Brasileira de Pavimentação-ABPV, Anais. v.1, p. 278-288.

RAMOS, C. R.; LÁO, V. L. do E. S. T.; MARTINHO, F. G.; MACEDO, M. M. D. (1996) Asfalto modificado com polímero uma opção para melhoria dos asfaltos nacionais. Anais do $13^{\circ}$ Encontro de Asfalto, v. 1, p. 60-82.

REIS, Rafael M. M. 2002 Revestimento Asfáltico Tipo SMA para Alto Desempenho em Vias de Tráfego Pesado. Disertação de MSc, EP-USP, São Paulo, SP, Brasil.

ROBERTS, F. L.; KANDHAL, P. S.;BROWN, E. R; LEE,D.Y.; KENNEDY, T. W. (1991) Hot mix asphalt materials, mixture design and construction. 1 ed., NAPA Research and Education Foundation, National Center for Asphalt Technology -NCAT, Lanham, Maryland, USA. 
ROBERTS, F. L., KANDHAL, P. S., BROWN, E. R; LEE,D.Y.; KENNEDY, T. W. (1996) Hot Mix Asphalt Materials, Mixture Design and Construction. 2 ed., NAPA Research and Education Foundation, National Center for Asphalt Technology -NCAT, Lanham, Maryland, USA.

SANTOS, G. C.R. (2005) Avaliação Das influências do tipo de ligante e do volume de vazios na vida de fadiga de algumas misturas asfálticas. Dissertação de M.Sc. EESCUSP, São Carlos, SP, Brasil.

SOUZA, J.B.; CRAUS, J.; MONISMITH, C. L.(1991). Sumary report on permanent deformation in asphalt concrete. Publicação SHRP-A/IR-91-104. Strategic Highway Research Program. National Research Council. Washington, D.C. 120 p.

SUPERPAVE EXPERT TASK GROUP. (2001) Superpave Mixture and Aggregate Expert Task Group Meeting Minutes. TRB, National Research Council, Washington, D.C., August 28, 2001.

TAIRA, C. (2001) Avaliação do desempenho em laboratório de misturas asfalticas densas utilizando asfalto convencional (CAP-20) e asfalto modificado com polimero SBS (Betuflex B 65/60). Dissertação de M.Sc., EESC-USP, São Carlos, SP, Brasil.

TAYEBALI, A. A.; GOODRICH, J. L.; SOUSA, J. B.; MONISMITH, C. L. (1992) Influence of the rheological properties of modified asphalt binders on the load deformation characteristics of the binder - aggregate mixtures. Polymer Modified Asphalt binders, American Society for Testing and Materials, ASTM STP 1108, p. 77-95. 
TIGDEMIR MESUT, KALYONCUOGLU S. FIGEN and KALYONCUOGLU U. YALCIN. (2004) Application of ultrasonic method in asphalt concrete testing for fatigue life estimation, NDT \& E International, Volume 37, Issue 8, December 2004, Pages 597602.

VALKERING, C. P.; LANCON, D. J. L.; HILSTER, and STOKER, D. A. (1990) Rutting resistance of asphalt mixes containing non-conventional and polymer-modified binders. Symposium - Improved Rut Resistance, Association of Asphalt Paving Technologists (AAPT), Proceedings, p. 590-609.

YILDIRIM YETKIN (2005). Polymer modified asphalt binder. University of Texas at Austin, Science Direct, $7 p$.

YILDIRIM Y., SOLAIMANIAN M., and KENNEDY T. (2000) Mixing and compaction temperatures for hot mix asphalt concrete. Research Report Number 1250-5 Texas Department of Transportation.

YODER E.J., AND WITCZAK M.W. (1975) Principles of Pavement Desing. Second edition. Wiley-Interscience publication New York USA.

WATSON, D. E., A. JOHSON, and D. JARED. (1997) The Superpave Gradation Restricted Zone and Performance Testing with the Georgia Loaded Wheel Tester. In Transportation Research Record 1583, TRB, National Research Council, Washington, D.C., 1997, pp. 106-111. 